\title{
Overtredingen en strafzaken in het amateurvoetbal : een analyse van de kompetitie 1980-1981 in de afdeling Limburg, KNVB
}

Citation for published version (APA):

van Galen, W. C. C. (1986). Overtredingen en strafzaken in het amateurvoetbal : een analyse van de kompetitie 1980-1981 in de afdeling Limburg, KNVB. [, Maastricht University]. De Vrieseborch. https://doi.org/10.26481/dis.19861204wg

Document status and date:

Published: 01/01/1986

DOI:

10.26481/dis.19861204wg

Document Version:

Publisher's PDF, also known as Version of record

\section{Please check the document version of this publication:}

- A submitted manuscript is the version of the article upon submission and before peer-review. There can be important differences between the submitted version and the official published version of record.

People interested in the research are advised to contact the author for the final version of the publication, or visit the DOI to the publisher's website.

- The final author version and the galley proof are versions of the publication after peer review.

- The final published version features the final layout of the paper including the volume, issue and page numbers.

Link to publication

\footnotetext{
General rights rights.

- You may freely distribute the URL identifying the publication in the public portal. please follow below link for the End User Agreement:

www.umlib.nl/taverne-license

Take down policy

If you believe that this document breaches copyright please contact us at:

repository@maastrichtuniversity.nl

providing details and we will investigate your claim.
}

Copyright and moral rights for the publications made accessible in the public portal are retained by the authors and/or other copyright owners and it is a condition of accessing publications that users recognise and abide by the legal requirements associated with these

- Users may download and print one copy of any publication from the public portal for the purpose of private study or research.

- You may not further distribute the material or use it for any profit-making activity or commercial gain

If the publication is distributed under the terms of Article $25 \mathrm{fa}$ of the Dutch Copyright Act, indicated by the "Taverne" license above, 


\section{Sportwetenschappelijke Onderzoekingen 10}

Overtredingen en strafzaken in het amateurvoetbal 
Voor Chantalle, Geertje en Bram 


\section{OVERTREDINGEN EN STRAFZAKEN IN HET AMATEURVOETBAL}

Een analyse van de kompetitie 1980-1981 in de afdeling Limburg, KNVB.

\section{ACADEMISCH PROEFSCHRIFT}

ter verkrijging van de graad van doctor in de Sociale Wetenschappen

aan de Rijksuniversiteit Limburg te Maastricht, op gezag van de Rector Magnificus Prof. Dr. F.I.M. Bonke, volgens besluit van het College der Dekanen

in het openbaar te verdedigen op donderdag 4 december 1986 om vier uur precies, in de aula van de universiteit

door

Willem Christiaan Cornelis van Galen geboren te Wassenaar in 1948 
Promotor: Prof. Dr. H. Philipsen

Co-Promotor: Dr. J.P.M. Diederiks

Referenten: Prof. Dr. J.P. Balkema

Dr. C.L. Ekkers 
Het verschijnen van dit proefschrift werd mede mogelijk gemaakt door financiële steun van het Instituut Sportgeneeskunde Limburg.

(C) 1986 W.C.C. van Galen

Tekstverwerking: Marjoke Arkenbout

Omslagfoto: Studio HP, Geleen

Niets uit deze uitgave mag worden verveelvoudigd en/of openbaar gemaakt door middel van druk, fotokopie, microfilm of op welke andere wijze ook zonder voorafgaande schriftelijke toestemming van $\boldsymbol{B}$. V. Uitgeverij de Vrieseborch 
Een proefschrift is altijd het produkt van meerdere personen. In dit voorwoord wll ik daarvoor een aantal mensen speclaal bedanken.

Allereerst Prof.Dr. H. Philipsen. Hij bood mij de gelegenheid om als wetenschapper zonder ervaring, deze ervaring op te doen en zorgde ervoor dat de tijdelijke baan een "vast" vervolg kreeg. Tijdens het vervaardigen van het proefschrift heeft hij voortdurend de procesgang bewaakt en door zijn kreativiteit talloze onderzoeksproblemen opgelost.

Mijn co-promotor Dr. J.P.M. Diederiks voor de deskundige en kritiese wijze waarop hij van het begin tot het einde van het onderzoek mij met raad en daad heeft bijgestaan.

De referenten Prof.Dr. J.P. Balkema en Dr. C.L. Ekkers voor hun vriendelijke en nauwgezette wijze van refereren. Prof.Dr. J.P. Balkema met name voor zijn opmerkingen op strafrechtelijk terrein; Dr. C.L. Ekkers heeft door $z 1 j n$ opmerkingen het totale onderzoeksverslag een duidelijker kop en staart gegeven hetgeen de kwaliteit van het verslag deed verbeteren.

De KNVB-afdeling Limburg ben ik erkentelijk voor hun toestemming om het materiaal wan strafzaken en wedstrijden te mogen verzamelen. Met name wilde ik vermelden de heren TImmermans, Rouschen, Gerards en mevr. Wielders. Gedurende de zomermaanden van 1981 hebben zij mij en anderen de gastvrijheid ên gelegenheid geboden om op het afdelingsburo in Nieuwstadt ons werk te doen.

Het zal duidelijk $z i j n$ dat het verzamelen van de gegevens niet door één persoon kon geschieden. Bij het koderen van de strafdossters kreeg ik hulp van Rob van de Ven, Marian Tiliy en Ans Huljben.

Annemie Pisters is speciale dank verschuldigd omdat zij op ufterst nauwkeurige wijze de belangrijkste kenmerken van 12.000 wedstrijden (!) heeft gekodeerd.

Michel Jansen en Plet Zinken zorgden ervoor dat de talloze onderzoeksvragen werden omgezet in computerprogrammas.

Drs. J. Difkstra van de T.H. te Eindhoven is behulpzaam geweest bif het programmeren van de kontrastgroepen-analyse. Henk Lebens heeft alle gegevens via de computer uitgedraaid. Hif heeft erwoor gezorgd dat de, woor mij tot dan toe onbekende computertaal, begrijpelijk werd. 
De tekstverwerking is in eerste plaats verricht door Sylvia Nelk en daarna overgenomen door Marjoke Arkenbout. Met name Marjoke ben ik erkentelijk voor het, tot vervelens toe, wijzigen van het verslag. Haar nauwgezetheid en kreativiteit bij het tot stand komen van dit proefschrlft heb ik altijd bijzonder gewaardeerd.

Gerry van Wunnik zorgde vor het vervaardigen van de diverse tabe1len.

Dank ben $1 \mathrm{k}$ ook verschuldigd aan twee broeders van de Beyart te Maastricht. Broeder Salman heeft het totale verslag op Nederlandse taalfouten gekorrigeerd; op een minutieuze wijze heeft hij dit werk verricht. Broeder van Herwaarden zorgde voor de Engelse samenvatting.

De capaciteitsgroep Mediese Sociologie wil ik bedanken voor de vrijheid die zij mij bood en liet om, op de voor mij karakteristieke wijze aanwezig te zijn. Dat vrienden mij, vroeger en nu Quillaume le Taciturne noemden, zal hen niet verwonderen.

Tenslotte, maar niet in de laatste plaats wil ik mijn ouders bedanken die mijn studie mogelijk maakten.

Hoewel de meeste werkzaamheden aan het proefschrift gedurende werktijd plaatsvonden, is het onvermijdelijk geweest dat ik het werk, al was het maar in gedachten, meenam naar huls. Daarom bedank $1 \mathrm{k}$ Chantalle voor de wijze waarop ze al die tijd steun en toeverlaat voor me is geweest. 

Langzaam en met loone stappen loopt men terug, weer bagint nu de strijd, foller dan colt vallen ze aan, Noord aangemoedlgd door "t succes, Zuld ongedullilg on zich te wreken. Daar heeft een oude Spartaan den bal, met moelte door den Haagschen stevigen captain veroverd, laag blj den grond en gewelldig hard stulft de blauw-zwarte tricot voorult, zellt om den IInker half-back heen, en draait en wendt zlch, met waggellende wiljde schreden door de achterhoede, dan de muts stevig in de oogen drukkend, neemt hlJ $z^{\prime} n$ kans waar, doch de doelverdediger kan den bal nog julst houden en ult 100 kelen kllnkt het "Cornerl" Daar gaat lemand naar den hoekvlak en legt den bal neer, hil schroeft zlch de pet stevlg op het hoofd, veegt de woorkant van de laars schoon en meet en meet weder de rulmte, angstig zlende naar den wind.

Voor het doel is het ean geweldige beweging. "leder $z " m$ mannetje" roept een oud gedlende. De blauwwltte zet zlch schrap, balt de vulsten, de kleine Rappenaar, kljkt en gluurt en lljkt wel eens zoo groot; kalm als een den, staat de lange goal verdedlger. Daar neemt de man in den hook zijn aanloopje. "Let op Bourl lerl" "een mannetje blj Timmermansl" roept men nog, dan volgt een algemeen duwen en wringen. Statig zelltt de bal met een zachten boag neder, beschenen door de reeds ondergaande zon. Links en rechts dringen en spartelen de spelers, daar komt on windvlaag, en de bal draait schuins in het doel. Plotselling trekt de blauw witte figuur de armen terug, en ongehinderd valt de vulle bal door de palen.

"Goal" schreouwt het publlek, alles krabbelt op de been en bestormt den man met het kalme gezicht en den regenmantel. Deze schudt wriendelljk met het hoofd en zegt: "Geen goall" Dan is het "+1Jd".

Citaat uit Muller, W. (1893) Athletiek en Voetbal 
HOOFDSTUK 1.

STRAFZAKEN IN HET LIMBURGSE AFDELINGS VOETBAL

1.1. Inleiding

1.2. Probleemstelling en daaruit afgeleide vraagstellingen

1.3. Struktuur KNVB en strafdossiersprocedure

1.3.1. Struktuur KNVB

1.3.2. Voorwaarden officiële straf

1.3.3. Strafdossiers

1.3.4. Straftoepassing

1.4. Onderzoekspopulatie

1.5. Gehanteerde onafhankelijke variabelen

1.6. Voor- en nadelen onderzoeksmateriaal

HOOFDSTUK 2.

TEORIEEN BETREKKING HEBBEND OP RESPEKTIEVELIJK

SPELERS - EN SCHEIDSRECHTERSGEDRAG

2.1. Inleiding

2.2. Het begrip agressie in de matschappelijke

situatie en in de sportsituatie

2.2.1. Agressie algemeen

2.2.1.1. Opzet

2.2 .1 .2 . Schade en normen

2.2.1.3. Agressie, middel of doel

2.2.2. Het begrip agressie in de sport

2.2.2.1. Opzet

$2 \cdot 2 \cdot 2 \cdot 2$. Schade

$2 \cdot 2 \cdot 2 \cdot 3$. De sportieve norm

$2 \cdot 2 \cdot 2.4$. Instrumentele en reaktieve agressie

$2 \cdot 2 \cdot 2 \cdot 5$. Definiêring van agressief gedrag 
2.3. Agressieteorieën 26

2.3.1. Instinktteorie 27

2.3.2. Frustratie-agressie teorie 27

2.3.3. Leerteorie 29

2.3.4. Emotie en aktivatieteorie 30

2.4. De sportsituatie 31

2.4.1. Algemeen 31

2.4.2. Spelregels en sankties in de voetbalsport 33

2.4.2.1. Spelrege1s 33

$2 \cdot 4 \cdot 2 \cdot 2$. Sankties $\quad 34$

2.5. Posttie en rol van de scheidsrechter 37

2.6. Konklusies 43

2.6.1. Zijn de agressieteorieèn toepasbaar op de sportsituatie 43

2.6.2. Relatie status scheidsrechter-teorie 47

HOOFDSTUK 3.

ONDERZOEK NAAR AGRESSIE IN DE VOETBALSPORT

3.1. Agressie van voetballers

3.1.1. Teoretiese uitgangspunten 49

3.1.2. Metoden en populatie 51

3.1.3. Resultaten 52

3.2. Onderzoek scheidsrechters 54

3.3. Samenvatting 55

HOOFDSTUK 4.

RELATIE TEORIE-ONDERZOEKSVARIABELE

4.1. Inleiding

4.2. Relatie teorie-variabele

4.3. Hypothesen, per onafhankelijke varlabele over kans op strafzaken en over aard en richting ervan. 
4.3.1. K1assenivo

4.3.2. Kompetitiezondag (seizoensverloop)

4.3.3. Verschil in plaats op de rangplaats

4.3.4. Afstand tussen de velden

4.3.5. Aantal doelpunten, doelpuntenverschil,

4.3.6. Thuis of uftspelen

4.3.7. Verenigingsgrootte

4.3.8. Urbanisatiegraad

4.3.9. Status scheldsrechter

4.4. Sanktie scheldsrechter en tuchtkommissie

4.5. Metodiese opmerkingen

HOOFDSTUK 5.

EIGENSCHAPPEN VAN WEDSTRIJDEN MET

EN ZONDER STRAFZAKEN

5.1. Inleiding

5.2. Klassenivo

5.3. Selzoensverloop (kompetitiezondag)

5.4. Rangplaatsverschi1

5.5. Afstand tussen de voetbalvelden

5.6. Aantal doelpunten, doelpuntenverschil en winst/verlies

5.7. Verenigingsgrootte

5.8. Urbantsatiegraad

5.9. Status scheldsrechter

5.10. Onderlinge samenhangen van de onafhanke $11 j k e$ variabelen 
5.12. Regionale kompetities $\quad 87$

5.12.1. Algemeen 87

5.12.2. Beschrijuing regio's 88

5.12.3. Werking onafhankelijke variabelen
per regio

5.13. Vergelijking van wedstrijden met en zonder strafzaken $\quad 92$

5.13.1. Diskriminant-analyse van wedstrijden met en zonder strafzaken 93

5.13.2. Kontrastgroepenanalyse van wedstrijden $\begin{array}{ll}\text { met en zonder strafzaken } & 98\end{array}$

5.14. Samenvating

HOOFDSTUK 6.

KENMERKEN STRAFZAKEN EN HET AANTAL

STRAFZAKEN PER WEDSTRIJD

6.1. Inleiding

6.2. Aard en richting overtreding

6.3. Tijdstip strafzaak

6.4. Scheidsrechterlijke sanktie

6.5. Sanktie tuchtkommissie

6.6. Het aantal strafzaken in een wedstrijd

6.6.1. Literatuur

6.6.2. Onderzoeksresultaten aantal strafzaken in een wedstrijd

HOOFDSTUK 7 .

TYPEN WEDSTRIJDEN NAAR AARD

EN RICHTING VAN DE OVERTREDING

7.1. Inleiding

7.2. Typen wedstrijden naar aard en rlchting overtreding 
7.3. Samenhang tussen de onafhankelijke varlabelen enerzijds en de wedstrijdtypen ander $z \mathbb{1} \mathrm{dds}$

7.3.1. Status scheidsrechter en $k l a s s e n i v o$

7.3.2. Overige onafhankelijke variabelen

7.3.2.1. Toetsing hypothesen instrumentele overtredingen

$7 \cdot 3 \cdot 2 \cdot 2$. Toetsing hypothesen reaktieve overtredingen

7.4. Sankties scheidsrechter en tuchtkommissie

7.4.1. Inleiding

7.4.2. Scheidsrechterlijke sankties per scheidsrechterskategorie

7.4.3. Sankties tuchtkommissie

7.5.

Samenvatting

HOOFDSTUK 8.

HET THUIS- EN UITSPELEN

8.1. Inleiding

8.2. Onderzoek t.a.v. de relatie thuisuitspelen en de kans op overtredingen of strafzaken

8.3. Welke faktoren bepalen het onderscheld tussen wedstrijden met strafzaken t.a.v. thuis- of uitklub

8.4. Samenhang tussen thuis-uitspelen en aard-richting overtreding

8.5. Samenvatting

HOOFDSTUK 9.

KONKLUS IES EN AANBEVELINGEN

9.1. Wetenschappelijke betekenis resultaten

9.1.1. Teorie 
9.1.2. Metode

9.1.3. Plaats onderzoek in bestaande onderzoekstraditie

9.2. Praktiese betekenis resultaten

9.2.1. De algemene situatie in het afdelings-

9.2.2. Welke faktoren kunnen het voorkomen van

9.2.3. Welke sankties kunnen spelers van scheidsrechters en tuchtkommissies verwachten

9.3. Beleidsaanbevelingen

9.3.1. Aanbevelingen vanuit ander onderzoek

9.3.2. Praktiese aanbevelingen

$\frac{\text { HOOFDSTUK } 10 .}{\text { SAMENVATTING }}$

SUMMARY 

HOOFDSTUK 1.

STRAFZAKEN IN HET LIMBURGSE AFDELINGSVOETBAL

1.1. Inleiding

Voetbal heeft sinds zijn ontstaan een grote populariteit gekend. De maatschappelijke betekenis van deze sport komt $0 . a$. tot uiting in het aantal aktieve georganiseerde voetballers; in Nederland in 1982 rulm 1 miljoen spelers in georganiseerd verband, waarvan 75.000 in de afdeling Limburg. De populariteit en massaliteit van het voetbal richt de aandacht echter niet alleen op de positieve waarden van de sport zoals ontspanning en gezondheid maar ook op de negatieve kanten ervan: het risiko van blessures en agressie van spelers en/of toeschouwers.

Onderzoek wijst uit dat van de kontaktsporten, voetbal en hockey, relatief, vergeleken met andere sporttakken, het grootste aantal blessures opleveren (Kranenborg, 1980a; WVC, 1985); in hoeverre blessures verband houden met spelbederf of spelverruwing is echter nog niet onderzocht.

Agressie in de voetbalsport wordt als een probleem ervaren. Dit blijkt o.a. uit het tot stand komen van een interdepartementale werkgroep van het voormalige ministerle van Cultuur, Recreatie en Maatschappelijk Werk (CRM) die een advies heeft uitgebracht over spelverruwing in de voetbalsport (CRM, 1977). Dit rapport heeft betrekking op het betaalde voetbal. Er zijn genoeg aanwijzingen echter dat ook op de amateurvelden spelovertredingen een probleem vormen. Wij kunnen hierbij wijzen op een staking van scheidsrechters in het amateurvoetbal, afdeling 's-Gravenhage in november 1982 . Deze staking had tot doel aandacht te vragen voor de agressie op en rond de velden die de scheidsrechters als bedreigend ervaren. De agressie op de amateurvelden blijkt ook uit een Zwartboek over het molesteren van amateurscheidsrechters (Covs, 1984).

Als we ervan uitgaan dat agressie in de voetbalsport een probleem vormt, is de volgende stap te overwegen of onderzoek ten aanzien van dit onderwerp nutt1g en zinvol kan zijn. Bij deze overweging speelt de stand van het onderzoek op dat moment een belangrijke rol. 
Onderzoek naar agressief gedrag op het voetbalveld is in het begin van de zeventiger jaren pas goed op gang gekomen; daarbij kunnen we verwijzen naar het onderzoek van Volkamer (1971) In Dultsland en van Ekkers en Hoefnagels (1972) in Nederland. Hoewel daarna meerdere onderzoeken ten aanzien van dit onderwerp zijn verricht (zle hoofdstuk 3), kan men toch stellen dat het aantal hiervan, tot nog toe, beperkt is gebleven. Dit betekent dat de diskussie over agressie zoals die hedentendage wordt gevoerd niet voldoende gedragen wordt door empiries materiaal.

Als men er van uit kan gaan dat onderzoek in een behoefte kan voorzien, is de stap die daarna genomen moet worden we 1ke probleemstelling men gaat hanteren en daarmee samenhangend welk type onderzoek verricht gaat worden. Bij de beantwoording van dit laatste punt is het, in leder geval voor het hier te beschrijven onderzoek, relevant aam te geven in welk prakties onderzoeksprogramma het onderzoek gestalte moet krijgen.

Het te starten onderzoek zou deel gaan uitmaken van het Hoofdprojekt Sport en Gezondheid aan de Rijksuniversiteit Limburg te Maastricht; dit projekt richt zich op vermeerdering van kennis die kan bijdragen tot bevordering van positieve effekten van de sportbeoefening op de gezondheid en terugdringing van negatleve effekten. In dit Hoofdprojekt is één van de deelprojekten, het projekt de invloed van spelregels op spelverruwing en spelbederf. Centraal staat daarbij de vraag "tot welke effekten leiden de spelregels en de manier waarop de spelregels worden uitgevoerd". Bif de ontwikkelling van dit deelprojekt is toendertijd (1976) gekozen voor een aantal operationele deelproblemen. Een van deze deelproblemen heeft als onderwerp "spelregels en overtredingen in de voetbalsport". Eén van de redenen om de voetbalsport te klezen is het grote aantal deelnemers an deze sport ên het daarmee samenhangend groot aantal blessures.

In het kader van de voetbalsport is reeds onderzoek verricht:

- de wijze waarop de spee1tijd door scheidsrechters wordt geregeld (Philipsen, 1980, 1983);

- bekijken en beoordelen van video-opnamen van overtredingen in het voetbal door spelers (Philipsen et al, 1984); Eên belangrijke konklusie van deze onderzoeken is dat spelregels in de voetbalsport een ruime interpretatiemogelijkheid bieden aan de participanten. 
Uit het eerstgenoemde onderzoek blijkt dat tijd bijtrekken door scheidsrechters niet berust op ondubbelzinnige toepassing van de spelregels; één van de bevindingen van het tweede onderzoek is dat spelers de ernst van overtredingen op verschillende wijze blljken te beoordelen; tevens bestaat geen duidelijke konsensus in welke mate overtredingen "tegen" de regels zijn of een onsportief karakter dragen.

- eksplorerend onderzoek onder voetbalscheidsrechters (Kranenborg, 1980b).

Het als latste genoemde onderzoek van Kranenborg willen wij hier iets uitvoeriger bespreken, omdat het in feite de aanleiding is geweest voor ons elgen onderzoek. Kranenborg geeft in een artikel warin dit onderzoek wordt besproken (Kranenborg, 1980b) allereerst aan, dat, als men Inzicht wil krijgen in de agressie op het voetbalveld, het o.a. belangrijk is na te gaan welk selektie mechanisme scheidsrechters hebben. Omdat over dit onderwerp hoegenaamd niets bekend is, was dit voor hem aanleiding een eksplorerend onderzoek te doen onder voetbalscheidsrechters. De klassen waarin zij floten varieerde van het afdelingsvoetbal tot de hoofdklasse zondagamateurs. De 88 scheidsrechters werd een uitspraken1ijst voorgelegd bestaande uit vijftig onderdelen, alsmede drie open vragen. De enquête werd klassikaal afgenomen na afloop van de training.

In het onderzoek werd getracht na te gaan, op welke wijze de scheidsrechters hun taak opvatten, de problemen die zij ervaren bij de warneming van de gebeurtenissen op het veld en hun opvattingen over het sanktiesysteem.

Hij konstateerde dat het verschil van mening bij de scheidsrechters over het algemeen groot is. Bovendien zijn deze verschillen systematies van aard, hetgeen wil zeggen dat de scheidsrechters niet op willekeurige punten van opvatting verschillen, maar dat er per scheidsrechter samenhang in de opvattingen over bepaalde zaken bestaat.

Kranenborg stelde in het slot van zijn artikel: "ook wit dit onderzoek kunnen geen conclusies getrokken worden ten aanzien van het gedrag van de scheldsrechter op het veld of een relatie gelegd worden tussen het gedrag van de scheidsrechter en de gebeurtenissen op het veld".

Met dit probleem in gedachten, hebben wij in het voorjaar van 1981 kontakt opgenomen met de Koninklijke Nederlandse Voetbalbond (KNVB) afd. Limburg, om na te gaan op welke ma- 
nier het onderzoek van Kranenborg aan de hand van feitelijk materlaal kon worden uitgebreid. Al spoedig werd ons een bllk gegund in de zogenaamde strafdossiers, waarin alle door de scheldsrechters officleel aanhangig gemaakte straffen in een wedstrijd worden beschreven. De inhoud van de strafdosslers was dermate veelzijdig en interessant dat we besloten deze dossiers tot onderwerp van onderzoek te maken.

Belangrijkste overweging hierbij was, dat de te verzamelen gegevens goed zouden passen in de probleemstellingen van het zojuist genoemde hoofd- en deelprojekt. Deze onderzoekskeuze betekende we1 dat onze onderzoeksvraag veranderde; niet a1leen het gedrag van scheldsrechters, maar ook het gedrag van spelers, uitgedrukt in overtredingen die door de scheidsrechter als officiêle strafzaak zijn benoemd, werden onderwerp van onderzoek.

Alle senioren kompetitlewedstrijden, met en zonder strafzaken, $(N=12.390)$ van het ten tijde van het kontakt met de afdeling Limburg KNVB lopende seizoen 1980-1981 werden in het onderzoek betrokken. Door wedstrijden zonder strafzaken mee te nemen in het onderzoek werd een belangrijk vergelijkingsobjekt gekreëerd.

Aanvankelijk lag het in de bedoeling om ook het blessureaspekt in het onderzoek op te nemen; omdat echter op de rullwedstrijdformulieren, die na ledere wedstrijd naar de KNVB moeten worden opgestuurd, nauwelijks door de klubs gebruik wordt gemaakt van de mogelijkheid te vermelden welke speler(s) vanwege een blessure uitgevallen is ( $z i j n$ ) tijdens de wedstrijd, hebben wij van dit voornemen af moeten zien.

1.2. Probleemstelling en daaruit afgeleide
vraagstellingen

We zifn b1f het begin van het onderzoek uitgegaan van een vrif algemene probleemstelling die later in een aantal prakthese vraagstellingen is onderverdeeld.

De algemene probleemstelling luidt: "In hoeverre komen wedstrijden met strafzaken voor in het amateurvoetbal en welke faktoren zijn hierop van invloed; welke zijn de belangrijkste kenmerken van strafzaken en welke sankties worden bij strafzaken toegepast." 
Het zal duidelijk zifn dat deze probleemstelling mede afgestemd is op de inhoud van het deelprojekt "de invloed van spelregels op spelbederf en spelverruwing".

Spelregels en sankties zijn onlosmakelijk met elkaar verbonden. Daarom is ook het aspekt van de sankties in de probleemstelling opgenomen.

Uit de probleemstelling valt af te lezen dat het ons allereerst gaat om een beschrijving van het verschijnsel. We willen kennis krijgen van de mate waarin agressie voorkomt en de vorm waarin zij naar buiten komt.

Daarnaast wilen we hypothesen formuleren die het verschijnsel trachten te verklaren. Deze hypothesen zijn zowel gebaseerd op teoretiese inzichten als op resultaten van ander onderzoek.

Hoewel de verantwoording van de hypothesen in hoofdstuk 4 zal plaatsvinden willen we, kort, de vragen die uft de probleemstelling geformuleerd $z i j n$ weergeven:

De eerste twee vraagstellingen hebben betrekking op een vergelijking van wedstrijden met en zonder strafzaken. De eerste vraagstelling luidt:

- zijn er bepaalde faktoren aan te wijzen die het verschil verklaren tussen wedstrijden met en zonder strafzaken (hfdst. 5).

Bij de vorige vraag zijn wedstrijden met strafzaken niet verder onderscheiden. In de volgende vraagstelling is $\mathrm{dit}$ onderscheid wel gehanteerd. Daarbij zijn wedstrijden met strafzaken onderverdeeld in een aantal typen wedstrijden. Deze typen worden bepald door de aard (instrumenteel of reaktief) en richting (ten opzichte van de speler of scheidsrechter) van de overtredingen die in deze wedstrifden tot strafzaak $z i j n$ geworden.

De tweede vraagstelling kan derhalve als volgt geformuleerd worden:

- kunnen we bepaalde faktoren aanwijzen die het verschil verklaren tussen wedstrijden met specifleke strafzaakkenmerken en wedstrijden zonder strafzaken (hfdst. 7). De vraagstelling gericht op alleen wedstrijden met strafzaken is:

- kunnen we bepaalde faktoren aanwijzen die het verschil in het aantal strafzaken per wedstrijd verklaren (hfdst. 6).

Bij de hierboven behandelde vraagstellingen is de wedstrijd analyse-eenheid. 
Daarnaast zijn nog een aantal vragen geformuleerd met de strafzaak als analyse-eenheid:

- welke gevolgen hebben bepaalde overtredingen voor de betrokken spelers, met andere woorden welke sanktie kunnen zij van resp. scheidsrechter en tuchtkommissie verwachten (hfdst. 7).

Tenslotte zijn twee vraagstellingen geformuleerd betrekking hebbend op de gestrafte partij (het thuis-uitspelen); vraagstellingen die zowel de wedstrifd als strafzaak als analyseeenheid hebben:

- is ex samenhang tussen de gestrafte partij enerzijds en de kans op strafzaken en aard en richting van de overtreding anderzijds (hfdst. 8).

- is er samenhang tussen de gestrafte partij en de zwaarte van de sanktie van scheidsrechter en tuchtkommissie anderzijds (hfdst. 8).

Voordat we een beschrijuling gaan geven van ons onderzoeksmateriaal en de variabelen die wij gehanteerd hebben om onze vraagstellingen te beantwoorden, willen we allereerst in het kort de struktuur van de Koninklijke Nederlandse Voetbalbond (KNVB) schetsen en de plats van het afdelingsvoetbal hierin.

Daarna wordt uitgelegd welke voorwaarden verbonden zijn aan het opleggen van offlcielle straffen en op welke wijze de officiele straffen behandeld worden.

1.3. Struktuur KNVB en strafdossierprocedure

\subsubsection{Struktuur KNVB}

De Konlnklifke Nederlandse Voetbalbond bestaat wit twee zogenaamde "sekties", de sektie betalid voetbal en de sektie amateurvoetbal.

A. De sektlie betaald voetbal is onderverdeeld in een ere- en voor reserve-e, terwijI daarnaast een kompetitie bestat voor reserve-elftallen (de c-elftallen).

Strafmatregelen die de scheidsrechters in het betaalde voetbal ter beschikking staan zijn de gele karten (officiele waarschuwingen) en rode kaarten (uit het veld

Registratie en verwerking van deze gegevens vindt plaats op het hoofdburo van de KNVB te Zeist. 
B. De sektle amateurvoetbal is onderverdeeld in het KNVBamateurvoetbal en het KNVB afdelingsvoetbal.

De amateurs spelen in regionale hoofdklassen, terwij1 daaronder $z i c h$ een kompetitie afspeelt in 4 verschillende klassen.

Strafmatregelen ten aanzien van deze amateurs worden, evenals bij het betaalde voetbal, verwerkt en geregistreerd in Zeist.

Het afdelingsvoetbal speelt zich af onder het KNVB-amateurvoetbal. Ook in het afdelingsvoetbal worden $4 \mathrm{klasse-}$ nivo"s onderscheiden. Dit betekent dat als men in de eerste klasse van de afdeling speelt en kamploen wordt, men kan promoveren naar de vierde klasse KNVB.

Rapportage en registratie van o.a. strafzaken vindt plats op de provinciale buro's van de KNVB. In Limburg is dit het buro te Nieuwstadt.

Belangrijkste konklusie van het bovenstaande is dat de door ons onderzochte populatie, het afdelingsvoetbal, het, qua nivo, laagst georganiseerde voetbal vertegenwoordigt.

\subsubsection{Voorwaarden offlciële straf}

Wanneer wordt een offlciele straf opgelegd door de scheidsrechter?

Ter beantwoording van deze vraag moeten we de Handleiding voor Scheidsrechters (KNVB, 1980) radplegen. Het voor ons relevante gedeelte, omvat regel 12 "overtredingen en wangedrag". Het woord regel is in dit verband enigszins misleidend, immers de uitleg ervan beslaat in totaal 24 bladzijden.

Voor een overzichtelijke behandeling is de materle in drie blokken verdeeld: overtredingen die een direkte wrije schop en eventuee 1 een strafschop tengevolge hebben; overtredingen die bestraft worden met een indirekte vrije schop en disciplinalre straffen. In bijlage 1.1 hebben we voor de eerste twee blokken de, in total 14 overtredingen die tot deze straffen leiden, opgesomd.

De disciplinaire straffen, die leiden tot het opmaken van strafdossiers, zijn te onderscheiden in waarschuwingen en uit het veld sturen. Volgens het Handboek voor scheidsrechters (KNVB, 1980) moet een speler een waarschuwing ontvangen indien hij: 
"1. het speelveld betreedt of opnieuw betreedt, nadat de wedstrijd is begonnen om zich bij de partij te voegen, of het speelveld verlaat gedurende het verloop van het spel (tenzif dit een gevolg is van een blessure) zonder, in beide gevallen, een teken van de scheidsrechter te hebben ontvangen dat deze daarmee instemt;

2 . herhaaldelijk de spelregels overtreedt;

3. door woord of handeling toont het niet eens te zijn met een beslissing van de scheidsrechter;

4. zich schuldig maakt aan onbehoorlijk gedrag."

Een speler moet van het speelveld gezonden worden, indien hij:

"1. zich naar het oordeel van de scheldsrechter schuldig maakt aan een gewelddadige handeling of ernstig gemeen spel;

2. onbehoorlijke of beledigende taal gebruikt;

3. zich blijft misdragen, nadat hij een waarschuwing heeft ontvangen."

\subsubsection{Strafdossiers}

Wanneer een scheidsrechter een speler een officiële waarschuwing geeft of hem verwijdert, is hij verplicht dit op het zogenaamde ruilformulier te vermelden. Dit betekent dat er een strafrapport moet worden gemaakt: het rapportformulier strafzaken.

Naast de scheidsrechter, zijn de beide klubs verplicht, indien de scheidsrechter een speler officieel waarschuwt of wegzendt, een rapportformulier strafzaken naar Nieuwstadt te sturen. De eventuele spelers betrokken bij het voorval, de aanvoerders en de grensrechters kunnen hun visie op het gebeuren in de rapporten weergeven. De grensrechters worden geleverd door en zijn lid van de twee betrokken klubs. De bijlagen $1.2 ., 1.3$. en 1.4 . bevatten de rapportfomulieren van resp. de scheidsrechter en de twee betrokken klubs). Soms, maar bij de afdelingswedstrijden is dit uitzondering, bevindt zich een rapporteur van de KNVB bij de wedstrijd; door hem wordt dan eveneens rapport opgemaakt. Eén strafdossier omvat alle strafzaken van één wedstrijd. Worden er in een wedstrijd meerdere officiele straffen gegeven, dan wordt van elke straf rapport opgemaakt. Incidentrijke wedstrijden kan men herkennen aan de dikte van het strafdossier! 
Inhoud

Hoewel de terminologie van de vragen wel eens verschilt, wijken de formulieren voor de scheidsrechter en de 2 betrokken klubs niet wezenlijk van elkaar af.

De formulieren bevatten wedstrijdgegevens, namen van de klubs en van de scheidsrechter, wedstrłjdzondag, uitslag, kenmerken van de straf zelf (ernst, tijdstip, dader, reden), de algehele situatie van de wedstrijd (al dan niet sportief) en het specifleke gedrag van de bestrafte vlak voor, tijdens en na de opgelegde straf.

Voor de volledigheid vermelden we hier dat de reden van de straf door de scheidsrechter aan de twee klubs wordt meegedeeld; deze reden wordt dan vermeld op het formulier.

Behandeling .

De behandeling geschiedt door de zogenaamde strafkommissies. Omdat de afdeling Limburg is ondervergeeld in vijf regios $z i j n$ er vijf strafkommissies, warin een aantal personen ( 4 tot 6) zitting hebben. Deze behandeling vindt meestal schriftelijk plaats. Op verzoek van én der betrokken partijen kan echter een mondelinge behandeling verlangd worden. In het jaarverslag van de afdeling Limburg (KNVB, 1981a) staat vermeld dat de diverse strafkommissies: de strafkommissies jeugd-, senioren-, dames-, zaal- en bedrijfs-zomeravondvoetbal 102 maal bij elkaar moesten komen voor het houden van mondelinge onderzoeken. In de afdeling werden total 2289 wedstrijden met strafzaken geregistreerd.

\subsubsection{Straftoepassing}

Wordt een strafzaak behandeld dan hangt de daarbij behorende straf af van:

1. de ernst van de gekonstateerde overtreding

2 . het "strafverleden" van de betrokken speler.

Krijgt een speler een straf opgelegd van de strafkommissie dan wordt dit aangetekend op een zogenaamde strafkart. Is een speler na deze straf drie seizoenen verder zonder straf

* De inhoud van de straftoepassing heeft in dit verslag uitsluitend betrekking op het seizoen 80-81; in de loop der jaren zijn in de strafbepalingen talloze wijzigingen opgetreden. 
dan wordt de strafkart vernietigd en begint hij met een blanko strafverleden. Dit gebeurt niet met de strafkarten van die spelers die een straf opgelegd hebben gekregen van 1 jaar schorsing of meer. Strafzaken kunnen door de tuchtkommisste geseponeerd worden.

De strafmaat varieert van een berisping tot een onvoorwaardelijke schorsing van én of meerdere jaren.

\subsection{Onderzoekspopulatie}

In totaal zijn gedurende het door ons geanalyseerde seizoen 1980-1981, 12.390 kompetitiewedstrijden in onze analyses betrokken. De kompetitie speelde zich af op vier verschillende klassenivo's; in totaal deden 1167 elftallen mee aan de seniorenkompetitie.

Van 1750 wedstrijden zijn strafdossiers opgesteld. Deze 1750 wedstrijden vertegenwoordigen 2678 individuele strafzaken.

46 Gestakkte wedstrijden maken deel uit van de populatie. Een acht-tal wedstrijden is gestaakt zonder dat de scheidsrechter een of meerdere spelers een officlële straf heeft opgelegd. In deze gevallen vond de scheidsrechter, om wat voor reden dan ook, het niet verantwoord de wedstrijd volledig uit te spelen.

In een aantal gevalien $(N=79)$ heeft eén en dezelfde speler in éên wedstríjd een waarschuwing gekregen én is uit het veld gestuurd.

In feite kan het tweede delict van de speler ook een waarschuwing geweest $z i j n$ want ook in het amateurvoetbal geldt dat 2 waarschuwingen gelijk staat met het uit het veld zenden. Formeel gezien betekent dit dat twee strafzaken opgemakkt zouden moeten worden; in de praktijk wordt een derge$11 \mathrm{jk}$ geval op één formulier strafzaken vermeld.

Bij de kenmerken van strafzaken hebben we besloten dergelijke gevallen als uit het veld zendingen te beschouwen, te meer omdat bij het invulien van het formulier strafzaken de antwoorden op de vragen in de meeste gevallen geënt zijn op het uit het veld zenden (tijdstip, reden).

Hoewel een verge11jking met het damesvaetbal interessant zou zifn, was dit door de geringe omvang van de dames-kompetitie in Limburg niet mogelijk. 81 Dameselftallen speelden gezamenlijk 574 wedstrijden; in 14 wedstrijden werden in totaal 22 strafzaken uitgedeeld. 
In onze populatie komt er dus op elke 7 wedstrijden, 1 voor met tenminste één strafzaak.

Een vergelijking met andere afdelingen van de KNVB is niet zonder problemen. Veel afdelingen gebruiken namelijk in hun jaarverslagen totaalcijfers van veld- en zaalvoetbal, terwijl niet altijd valt op te maken of bij de aantallen strafdossiers vriendschappelijke- of bekerwedstrijden zijn opgenomen.

Ter oriëntatie geven we de cijfers van 2 afdelingen voor het seizoen 80-81. De afdeling Noord-Holland registreerde 28.945 senioren-voetbalwedstrijden, met 2.298 strafdossiers (een verhouding van 12:1) (KNVB, 1981b); de afdeling Dordrecht vermeldde op 5.332 wedstrijden 732 strafdossiers (verhouding van $7: 1$ ) (KNVB, 1981C).

1.5. Gehanteerde onafhankelijke variabelen

Uiteraard wil men in onderzoek zoveel mogelijk verklarende faktoren (variabelen) betrekken; in ons geval wordt echter de keuze van de variabelen beperkt door de aard van ons materiaal. Immers van wedstrijden zonder strafzaak kennen wij slechts een aantal objektieve kenmerken. Naast de namen van de twee betrokken elftallen zijn dit:

- klassenivo

- kompetitiezondag (seizoensverloop)

- verschil in plaats op de ranglijst

- afstand tussen de velden

- uitslag (uitgedrukt in aantal doelpunten, doelpuntenverschil en winst/verlies)

- thuis - uitspelen

- verenigingsgrootte

- urbanisatiegraad

- status scheidsrechter.

Bif de formulering van de probleemstellingen zijn deze variabelen als faktoren benoemd. Deze variabelen zullen derhalve worden betrokken bij het vergelifken van wedstrijden met en zonder strafzaken.

Een uitzondering hierop is de variabele thuis-uitspelen. Wanneer we ons afvragen welke faktoren het versch11 verk1aren tussen wedstrijden met en zonder strafzaken is het nlet mogelijk het thuls-uitspelen als faktor in deze vraagstelling op te nemen; een wedstrijd kan immers niet een kenmerk 
thuis-uft hebben. Deze variabele neemt dus een aparte positie in en kan alleen gehanteerd worden bij een interne ana1yse van wedstrijden met strafzaken.

De status van de scheidsrechter, een variabele waarvan de inhoud wellicht de meeste vragen oproept, houdt in dat onderscheid gemaakt kan worden tussen officiële scheidsrechters en niet-officiële scheidsrechters. De laatste kategorie heeft geen offlclële scheidsrechterskursus gevolgd; omdat het aantal wedstrijden op een wedstrijdzondag het aantal officielle scheidsrechters overtreft moet men een beroep doen op deze niet-officielle. In het verloop van het verslag zu1len wij deze eerste kategorie afwisselend "wedstrijdleiders" of "niet officiele scheidsrechters" noemen.

Uiteraard wordt op al deze variabelen nog nader ingegaan, maar we willen op deze plaats, kort, de keuze ervan verantwoorden.

Wanneer we in het algemeen literatuur ten aanzien van het onderhavig onderwerp bekijken (zie ook hoofdstuk 3) dan is er een aantal faktoren aan te wijzen waarvan men aanneemt dat zij invloed heeft, of samenhangt met het begaan van overtredingen en daarmee gepaard gaande (officiéle) straffen. Eén van deze faktoren is het belang van de wedstrijd. Dit belang kan diverse komponenten bevatten: wedstrijden waarin promotie of degradatie in het geding is, of het belang van een bepalde wedstrijd voor twee specifieke verenigingen. Miermans (1955) geeft als één van de oorzaken van de populariteit van voetbal "de mogelijkheid tot het uitspelen van de zich manifesterende rivaliteit die tussen steden, dorpen en buurten onderling en wederkerig bestond"; met van rivaliteit. Onder druk van dit belang zouden spelers, volgens diverse onderzoekers, eerder overgaan tot het maken van overtredingen. Gebeurtenissen op het veld zouden zwaarder worden gewotegen, het voortdurend lastig het krijgen van een doelpunt genstander, zouden eerder frusterend werken door een tewedstrijden dan in wedstrijden warin werk in belangrijke staat. Pilz, (1982) refereert aan warin niets op het spel warudt blijkt dat $54 \%$ van de onderzon onderzoek van Heinila $30 \%$ van de amateurvoetballers vindt strijden alle middelen geoorloofd dat in belangrijke wed- 
Echter, en dat geeft tevens de mogelijkheid van dubbele interpretatie van ons onderzoeksmateriaal weer, ook scheidsrechters kunnen onder druk van het belang een ander warnemings- en beoordelingsbeleld voeren.

Wij hebben getracht in het onderzoek een aantal variabelen te gebruiken die al dan niet direkt het belang van een wedstrijd vertegenwoordigen zoals het klassenivo, het seizoensverloop, plaats op de ranglijst, afstand en uitslag. Daarnaast zijn er ook variabelen die betrekking hebben op de sociale kontekst bijvoorbeeld de verenigingsgrootte en urbanisatiegraad.

Naast deze faktoren zijn er nog talloze variabelen die hoewel wellicht van invloed op het maken (of overwegen) van overtredingen, in ons onderzoek niet meegenomen worden: slechte herinneringen uit voorgaande wedstrijden, arbitrale onjulstheden, vrees de plaats in het elftal te verliezen; daarom hebben wij, wanneer wedstrijden met en zonder strafzaken vergeleken worden, geen al te hoge verwachtingen over de te verklaren variantie.

Uit de hlernavolgende twee cltaten blljkt dat bljvoorbeeld persconlljke omstandigheden die ulteraard inlet in het onderzoek betrokken konden worden rol kunnen spellen bll het voorkomen van agressief gedrag:

- sekretaris gestrafte partil geeft toelichting:

"de famille ... bestaat uit vader, moeder en zeven kinderen warvan de oudste is getrouwd. De rest is nog thuis en betreffend lid is de oudste. Vader en moeder zljn belde reeds Jarenlang zlek en nlet meer tot werken in staat. Daarbil komt nog het felt dat maeder twee maanden am vader drle maanden samen in het $z$ lekenhuls hebben gelegen.

Betreffend IId is dus zeer zwaw belast ondat hil een jongen is met een enorme plichtsbetrachting. Door al deze spanningen, welke hll de laatste Jaren en zeker de laatste maanden heeft meegemakt is hij vermoedelljk tot deze agressle gekomen, lets anders is bljna ondenkbaar ondat $\mathrm{hl}$ een zeer goed en rechtvaardig karakter heett." 
- grensrechter gestrafte partij:

"J ammer voor deze Jongen die noolt lets doet, maar op thet ogenblik boordevol echtelljke problemen $z l t$, maar dit weet de scheidsrechter natuurlijk nlet."

\section{Redaktionele opmerking}

In de nu volgende hoofdstukken zal soms gebruik worden gemaakt van letterlijk opgenomen teksten uit de strafformulieren van de scheidsrechter en/of de twee betrokken klubs (b1jlagen $1.2,1.3$ en 1.4). Deze teksten staan tussen haakjes en dragen een ander lettertype dan de rest van het verslag.

Weergave van deze teksten heeft een tweeledig doe1: Ten eerste willen wif de lezer laten zien hoe de formulieren zijn ingevuld. Ten tweede hebben de teksten een voorbeeldfunktie voor bepaalde hoofdstukken of paragrafen.

\subsection{Voor- en nadelen onderzoeksmateriaal}

Wat de voordelen betreft was een belangrijke praktiese overweging (naast de geschikte inpassing in het bestaande projekt) dat we snel en efficlent konden beschikken over feitelijk materiaal over agressie, of, wargenomen agressie, op het voetbalveld. Immers, een van onze belangrijkste wensen ten aanzien van het te starten onderzoek, het beschikken over feitelijke gegevens, kon worden vervuld. Het verschijnsel dat ook op de amateurvelden veel agressie plaatsvind is overigens in tegenspraak met de algemene verwachting dat, met name in het laagst georganiseerde amateurvoetbal, spelers plezler en ontspaming zullen laten prevaleren, boven het "met alle mogelijke middelen" behalen van de winst. We realiseerden ons tevens dat we door deze keuze andere mogel1jkheden om de agressie in het voetbalspel te analyseren, bifvoorbeeld het ondervragen van spelers of coaches, over dit onderwerp, of het zelf observeren van wedstrijden daarbij uitsloten, maar bij iedere keuze zijn dergelijke konsekwenties onvermijdelijk. Naast de empirische relevantie speelde bif de keuze ook de teoretlese relevantie een rol. Hoewel onderzoek naar strafzaken nauwelijks is verricht waren ons tenminste twee onderzoeken bekend, in Nederland van 
Ekkers en Hoefnagels (1972), en in Duitsland van Volkamer (1971), die de mogelijkheid boden de gevonden resultaten te vergelijken.

De nadelen van het onderzoek zijn vooral van metodologiese aard. Allereerst kunnen we opmerken dat het onderzoek van de strafdossiers een voorbeeld is van een zogenaamd post-factum-experiment (een vergelijkend onderzoek, waarbij de ene groep wel en de andere groep niet an de werking van een faktor heeft blootgestaan (Vercruijsse, 1970).

Een van de bezwaren van dergelijk onderzoek is volgens Albrecht (1982) dat, in ons geval, de wijze waarop men agressief gedrag definieert, de resultaten kan beinvloeden. Bij efgen onderzoek stelt hij vast dat indien men als uiting van agressief gedrag officiele waarschuwingen neemt, andere resultaten worden verkregen als dat men voor deze uitingen alleen "uit het veld zendingen" gebruikt.

Daarenboven voert hij als meer algemene kritiek aan, dat bij post factum experimenten de onafhankelijke variabelen niet naar keuze gevarieerd kunnen worden, terwij1 tevens "randomisering" (de willekeurige opbouw van experimentele en kontrole groep) niet mogelijk is.

Een ander bezwaar is de selektie van het onderzoeksmateriaal. Deze selektie vindt bij de strafdossiers plaats door: a. de selektie van bepaalde overtredingen; alleen die overtredingen worden onderwerp van onderzoek die geleid hebben tot het opmaken van een strafdossier; aangenomen mag worden dat dit veelal de meest ernstige overtredingen zullen zijn;

b. de scheidsrechter, die waarschijnlijk op het veld zelf ook bepaalde strategieen inzake wel of niet straffen hanteert (Kranenborg, 1980b); dit betekent dat bij een gelifke ernst van de overtreding er een selektie door iedere scheidsrechter plaatsvindt op grond van zijn strategie en interpretatie van de spelregels.

Om een beeld te krijgen van een dergelijke selektie kunnen we verwijzen naar onderzoek van Albrecht (1.979b) die konstateert dat 1 op de 25 overtredingen tot een strafzaak leidt, terwijl Begerau (1981) bij 9 voetbalwedstrijden op een aanta1 van 118 vrije schoppen, 2 officiele strafzaken telt! Algemene kritiek op een onderzoek van Volkamer (1971), van o.a. Begerau, (1981) en Pilz, (1979) is, dat hij uit zijn materiaal, door scheidsrechter waargenomen en officieel bestrafte overtredingen, de konklusie trekt dat de meeste wed- 
strijden niet 'unfalr' zijn, gelet op het aantal waarschuwingen en uit het veld zendingen. Kan het, aldus $P i 1 z$, niet zo zijn, dat agresslef gedrag in de hogere klassen enerzijds meer verdekt dus minder makkelijk warneembaar is en anderzljds de scheidsrechters meer hardheid dulden?

Een verdere beperking van het onderzoeksmateriaal is de niet te meten invloed van de "omgeving": trainers, bestururders e.d. (zle Ekkers en Hoefnagels, 1972 en Fris, 1972).

Bif de beantwoording van de vragen naar het warom van het begaan van overtredingen of het voorkomen van strafzaken wordt door bijna alle onderzoekers gebruik gemaakt van het begrip agressie.

Daarom willen we eerst nagaan wat men in het algemeen onder agressle verstaat, welke teorieèn aan dit begrip ten grondslag liggen en in hoeverre de voetbalsport al of niet agressie bevorderend werkt. 
HOOFDSTUK 2.

TEORIEEN BETREKKING HEBBEND OP RESPEKTIEVELIJK SPELERS- EN SCHEIDSRECHTERSGEDRAG

\subsection{Inleiding}

In dit hoofdstuk willen wij teorieên bespreken die voor ons onderzoek relevant zijn.

Indien wij ons bezighouden met het gedrag c.q. de overtredingen van spelers ligt een bespreking van agressieteorieèn en het begrip agressie voor de hand. De agressieteorieën worden vaak in andere onderzoeken die overtredingen of strafzaken van voetballers als onderwerp hebben, veelal als teoretles referentlekader gebruikt (zie hoofdstuk 3).

Naast het spelersgedrag kunnen we echter ook ingaan op de positie en rol van de scheidsrechter; hij is immers de bron van ons onderzoeksmateriaal. Wanneer we ons bezighouden met het scheidsrechterlijk gedrag speelt de vraag een rol naar de faktoren die scheidsrechterlijke warnemingen en het aanhangilg maken van strafzaken beinvloeden.

Deze vraag hebben wij gerelateerd aan aspekten van rol- en cognitieve teorieën.

De opbouw van het hoofdstuk is, gelet op bovenstaande opmerkingen, daarom als volgt: allereerst wordt ingegaan op het begrip agressie en de toepassing ervan in de matschappelijke- en sportsituatie ( $p a r .2 .2$ ); omdat veel onderzoeken voor het verklaren van agressief gedrag gebruik maken van agressieteorieën worden deze teorieën in par. 2.3 behandeld.

Vervolgens gaan we nader in op de sportsituatie in het algemeen en de voetbalsportsituatie in het bijzonder (par. 2.4). Een door velen ingenomen standpunt is dat het vórrkomen van agressie in de sport verband houdt met de struktuur van de sport. De struktuur bepaalt de spelregels; sanktles zijn onlosmakel1jk met deze spelregels verbonden. Spelregels en sankties in de voetbalsport vormen derhalve hoofdbestanddeel van par. 2.4.

De positie van de scheidsrechter wordt in paragraaf 2.5 in een teoretles kader geplaatst.

Tenslotte wordt in par. 2.6 nagegaan in hoeverre de in dit hoofdstuk behandelde teorieën inderdaad toepasbaar zijn op ons onderzoeksmateriaal. 
2.2 .

Het begrip agressie in de matschappelijke situatie en in de sportsituatie

\subsubsection{Agressle algemeen}

Het woord agressie is afgeleid van aggredi = uitgaan naar. Ieder handelen is in deze betekenis agresslef, ondernemend of ekspansief. Het woord agressie krijgt betekenis naar de mate van herkenbaarheid in bepald gedrag (Hoefnagels, 1980).

Een definttie van agressie die in de literatuur veel geciteerd wordt is die van Dollard (1939): agressie is het met opzet schade toebrengen aan een organisme. Naast de komponenten opzet en schade geeft deze definitie impliciet aan dat sprake is van uiterlijk waarneembaar gedrag; dat wil zeggen tussen agressie en agressief gedrag wordt in feite geen verschil gemaakt. Het in stilte toewensen van een vreselijke ziekte aan een ander, verwijst wel naar een agressleve geneigdheid, maar niet naar agressief gedrag (Fris, 1972).

Deze uitleg van agressie, als zijnde agressief gedrag, is naar onze mening ook een eksponent van de betekenis die er in het dagelijks spraakgebruik aan gegeven wordt.

Het is duidelijk dat in de definitie van Dollard twee elementen een rol spelen, de opzet, de doelbewustheid van degene die het agressief gedrag vertoont én het gevolg van de handeling, de schade die het voor de ander heeft. Deze elementen willen we hier, kort, behandelen.

2.2.1.1. Opzet

Men kan stellen dat er gaandeweg een diskussie is ontstaan over de inhoud van het element opzet. Het element is moei$11 \mathrm{jk}$ operationaliseerbaar en meetbaar en het moet uit de kontekst van de gedraging blijken (Ekkers, 1975).

Wiegman et. a1. (1982) z⿺jn van mening dat het moeilijk is uft te maken wat nu de eigenlijke bedoeling van iemand is geweest. Zij menen dat het kennis-moment, het weet hebben van de daad, betere praktiese mogelijkheden biedt dan het gebrulk van een (volgens hen) vaag begrip als intentie. Een middel om de problematiek van het element opzet te omzellen is door niet te praten over opzet, maar over de verwachting bij de dader dat zijn gedrag schadelijk zal zijn. 
ofschoon ook de verwachting niet objektief warneembaar is, is zij, volgens o.a. Fris (1972) en Ekkers (1975), wel gemakkelijker uit de kontekst van een gedraging af te leiden. Volgens hen valt op deze manier ook dat gedrag, dat wel schadelijk is, maar primair een ander doel heeft dan het kwetsen van de ander, onder de definitie van verwachting. Op deze zgn. instrumentele agressie komen we in dit hoofdstuk (par. 2.3.3) nog terug. Het element opzet of verwachting legt het aksent op het gedrag van de "dader".

\section{2 .1 .2 . Schade en normen}

Het element schade verwijst naar de vraag wat de gevolgen voor het "slachtoffer", de ontvanger zijn. Simons (1972) haalt een Amerikaans onderzoek van Meisels en Dosey aan; in dit onderzoek werd onderzocht in hoeverre personen zulver fystologies op de toenadering van anderen reageerden. Er zou sprake $z i j n$ van een kritiese afstand (body buffer zone); deze afstand zou groter zijn bij degenen die men zou kunnen typeren als min of meer agressief.

Gewoonlijk worden, wat de uitdrukkingsvorm van het gedrag betreft, twee vormen onderscheiden, namelijk de verbale agressie, uitlatingen in woord of geschrift (belediging e.d.), en de fysieke agressie, waarbij de schade bestat uit lichamelijke pijn of letsel. Bij een vergelijking van deze twee vormen is de fysieke agressie gemakkelijker te konstateren; dit hoeft niet te betekenen dat de gevolgen van fysieke agressie altijd ernstiger zijn dan de gevolgen van verbale agressie.

"De deuk in de eigenwaarde door een onverwachte 'klap' kan soms aanmerkelijk pijnlijker $z i j n$ dan de onaangename gewaarwording van een blauw oog." (Fris, 1972)

over de onderlinge relatie tussen fysleke en verbale agressie merkt Fris op dat de verbale agressie vaak vooraf blijkt te gaan aan het fysieke geweld.

In kritiek op de oorspronkelijke definitie van Dollard (1939) hebben sommigen (o.a. Buss, 1961) het element opzet buiten de definitle, gelaten zodat alleen de schade overbleef in de definitie.

o6k deze definltie leverde moellijkheden op om toegepast te worden in de konkrete situatie. Gedrag zou dán alleen agressief zijn indien de schade duidelifk waarneembaar was. Fris (1972) haalt hierbij het voorbeeld aan van een persoon die een ander slaat; de agressie ontstaat pas wanneer de een, 
de ander daadwerkelijk raakt. Ook het (pijnlijk) gedrag van de tandarts zou dan onder een dergelijke definitie vallen. Volgens Ekkers (1975) kan zo'n definitie als een soort (bas1s)uitgangspunt dienen; in tweede instantie kunnen we aangeven of er bij bepaalde gedragingen overeensteming is met matschappelljke normen.

Bandura (1973) noemt het gedrag van de tandarts "het uitoefenen van een social gesanktioneerde funktie".

"Het moet echter", volgens Ekkers (1977), "als onmogelijk worden gezten een definitie van agressie op te stellen die prectes dat gedrag afgrenst, dat volgens alle leden van een matschappij als agressief gezien wordt. Maatschappelijke opvattingen hierover geven verschillen te zien tussen verschillende groeperingen in de matschappij en fluktueren bovendien 1 in de tijd."

Zowel Elias (1976) als Dunning (1983) maken duidelfjk dat de tolerantiegrens ten aanzien van geoorloofd fysiek geweld is ingebed in de geweldstandaard van de matschappij. Er is langzamerhand een zodanige kontrole op het geweld ontstaan dat "bloot" geweld vervangen is door meer rationele agressie.

2.2.1.3. Agressie, middel of doel

Nast de diskussie over de feitelijke inhoud van het begrip agressie blijft de vraag bestaan omtrent het beoogde effekt van agressie. Daarbij wordt veelal een onderscheid gemaakt tussen instrumentele en reaktieve agressie.

Bij instrumentele agressie is de agressie gericht op het bereiken van een bepaald doel, met andere woorden men gebruikt het als middel, instrument. Begrippen en termen die veelal bij deze vorm gebruikt worden zijn o.a. planning, rationaliteit, koele berekening, funktionaliteit. Ekkers (1975) noemt
als voorbeelden van instrumentele agressie, roofmoord, bank-
overval e.d. Bij reaktieve agressie is het agressieve gedrag doel op zlch. Belangrijk kenmerk van deze agressie is dat ze veroorzaakt wordt door een aantal door het individu als zodanig frustrerende handeling van iemand an is een reaktie op een diglng, slaan, schoppen). In verbers (bijvoorbeeld beleagressie worden ook begrippen gebruikt met deze vorm van digend, affektief, expresstef gebruikt als emotioneel bevre- 
angry, hostile). Het natrappen van onsportieve tegenstanders zou als voorbeeld voor reaktieve agressie kunnen dienen. Echter, de scheiding instrumenteel/reaktief is niet altijd duidelijk; bijvoorbeeld het lastig vallen van voorbijgangers. Reaktief is dit gedrag in die zin dat men reageert op bijvoorbeeld uiterlijke kenmerken van het slachtoffer, zonder dat dit gedrag, althans voor een buitenstaander funktioneel lijkt te zijn. Echter voor de agressor kan het lastig vallen als instrumenteel beschouwd worden: het doel van het lastig vallen kan immers $z i j n$ dat zijn aanzien bij anderen wordt vergroot.

Ekkers' voorbeeld om bijvoorbeeld een bankoverval als instrumentele agressie te beschouwen, laat onverlet dat er verschillende soorten overvallen plaatsvinden die, uitgaande van een matschappelijke norm, meer of minder agressief genoemd kunnen worden. Het overvallen van een bank met behulp van een speelgoedpistool, geeft hoewel het in strijd is met de norm, minder afkeuring dan een overval gepaard gaande met het koelbloedig neerschieten van bankemployees en toevallige voorbijgangers. In het laatste geval zijn middel en doel wel bijzonder ver van elkaar verwijderd en is het de vraag of instrumentele en reaktieve agressie niet in elkaar overgaan. In feite is, volgens Bandura (1973) en Ekkers (1975) elk agressief gedrag instrumenteel; het onderscheld is voor hen derhalve kunstmatig. Pilz (1982) merkt op dat het om ideaaltypen gat: gedrag is nooit volledig rationeel of emotioneel.

Daarom lijkt het, volgens Bandura (1973), beter, agressieve handelingen te onderscheiden in termen van de funktionele waarde ervan eerder dan in termen van het al dan niet instrumenteel $\mathbb{z} i j n$.

Ondanks de hierboven genoemde beperkingen van het onderscheid instrumentele versus reaktlieve agressie menen we dat het onderscheid betrokken op de sportsituatie een handzaam instrument kan zijn om agressief gedrag te beoordelen.

In de volgende paragraf willen we de hier behandelde elementen opzet, schade, norm en het onderscheid instrumenteel en reaktief agressief gedrag toepassen op de sportsituatie. 
2.2.2. Het begrip agressie in de sport

$2.2 .2 \cdot 1$. Opzet

gestrafte speler:

"bij het achternazitten van de tegenspeler raakte Ik dezen van achteren met de bedoeling de ball te spelen *1

gestrafte speler:

"Ik kon de bal nog net bereiken en wegtrappen, warna mijn tegenspeler over mijn been viel. Volgens mill was er wel sprake van een overtreding van mijn kant andat or enig gevaar voor mijn tegenstander ontstond door mljn aktle.

Er was echter zeker geen sprake van opzet van mijn kant, want lk probeerde alleen de bal weg te spelen."

Een reden voor Gabler (1976) om het element opzet in de deflnitie van agressie te gebruiken is, dat, áls we allén maar over het gevolg (schade) praten, we niet veel verklaren. Immers, elke blessure opgelopen in een sportsituatie zou dan veronderstellen dat hieraan agressief gedrag ten grondslag ligt. Echter in een sport als voetbal zijn zuiver ongelukkige botsingen met daaraan verbonden blessurerisiko"s lang niet altijd als gevolg van agressieve handelingen te verklaren.

Ekkers (1975) die in zijn definitie van agressie, waaraan we zojuist gerefereerd hebben, niet spreekt over opzet, maar over verwachting, vindt zijn definitie toepasbaar op de sportspecifleke situatie. Handelingen in de sport zijn dermate geroutiniseerd, dat, in de meeste situaties warin fysleke pijn of letsel veroorzaakt wordt, de dader had kunnen verwachten (dat wil zeggen niet persé met $100 \%$ kans, maar met een redelijke warschijnlijkheid) dat pijn of letsel het gevolg zou zijn van dergelijk gedrag. 


\section{$2 \cdot 2 \cdot 2 \cdot 2$. Schade}

Wanneer we de 2 uitdrukkingsvormen van agressie (zie par. 2.2 .1 .2 ) in herinnering brengen (verbaal en fysiek) blijft in de sportsituatie nog een vorm van gedrag over welke in fefte nog onder de verbale, noch onder de fysieke agressie is onder te brengen.

We doelen op de vorm van agressie die vooral handelingen betreft die er bijwoorbeeld op gericht zijn "tijd" te winnen". Gabler (1976) spreekt in dit verband van symboliese agressie. Ook Cauwe1s (1977c) spreekt over symbollese agressie; daaronder verstaat hij "het dreigen met de vuist (of stick of racket); ook beledigende handbewegingen, gebaren en gelaatsuitdrukkingen kunnen agressieve intenties verraden". Men zou dit soort overtredingen als schadelijk voor "het spel" kunnen beschouwen. Het handboek voor voetbalscheidsrechters spreekt over spelbederf.

Uit de navolgende hoofdstukken zal nog blijken dat wat voetballers onder schade verstaan, mede bepaald wordt door het nivo waarop men zijn sport beoefent (o.a. Pilz, 1982). Naast het element opzet en schade wordt in de sportsituatie ook "het in strijd zijn met de sportieve normen", als element bij de definitie van het begrip agressie gebruikt.

\section{$2.2 \cdot 2 \cdot 3$. De sportieve norm}

Zowe 1 Begerau (1981), Gabler (1976) als Schilling (1976) nemen de sportieve norm op in hun definitie van agressief gedrag in de sportsituatie. Door het hanteren van het normelement, bestaat er gerede kans dat er tevens een nieuw diskussie-element is bijgekomen; immers wat zijn sportieve normen en wanneer is gedrag daarmee in strijd? Gabler (1976) beantwoordt deze vraag door erop te wijzen dat per tak van sport aangegeven moet worden welke (in)formele regels er zifn; (zie ook Schilling, 1976). Obstruktie heeft in de voetbalsport een andere betekenis, als bij hardlopen. Een ekstra moeilijkheid bij het toepassen wan het norm-element is, dat normen niet zwart op wit staan (Smith, 1974).

Dat wil zeggen, ze kunnen als inofficielle spelregels (ideelle normen) in de betekenis van min of meer wederzijdse verwachtingen opgevat worden. Met behulp van deze normen worden handelingen beoordeeld en gewaardeerd. Ook al zijn normen en regels begripsmatig onderscheiden, ze kunnen elkaar wederzijds belnvloeden (Cauwe1s, 1977c). 
Zowel Begerau (1981) als Gabler (1976) hebben bij het bepalen welke handelingen in de sportsituatie agressief genoemd kunnen worden, gebruik gemaakt van een (zelf ontworpen) klassiflkatlesysteem waarin het element van de sportieve norm tot uftdrukking komt. Begerau onderscheidt 3 typen overtredilngen:

1) onopzettelijke overtredingen;

2) opzettelifke overtredingen die spelvoordeel opleveren; (hif noemt deze instrumenteel)

3) opzettelijke overtredingen die gericht zijn op persoonlifke schade; de laatste vorm is in tegensteling tot de eerste twee vormen tegen de sportieve norm gericht.

Gabler geeft een typologie met vier mogelijkheden: wel of niet tegen de regels, gekombineerd met al dan niet tegen de sportleve norm.

Pilz (1979) bekritiseert de zienswijze van Gabler. Het is volgens hem problematies in onderzoek een definitie van agressle te gebruiken warin het al dan niet geaksepteerd $z 1 j n$ van de norm door de interaktiepartners is verdiskonteerd; daarbij treedt tevens, volgens Pilz, het gevaar op dat het gedrag van een persoon door zijn eigen uitspraken wordt geklassificeerd.

De auteurs die de problematiek van de sportieve norm behandelen (o.a. Begerau, 1981, Cauwe1s, 1977c, Ekkers, 1975, Ellas, 1976a; Gabler, 1976 en Pilz, 1979) zijn het er over eens dat de normen in de $t i j d$, per tak van sport, of zelfs per individu kunnen varieren.

\subsubsection{Instrumentele en reaktieve agressie}

Zoals we in par. 2.2.1.3 aangegeven hebben is ons inziens het onderscheid instrumentele en reaktieve agressie, ondanks de bezwaren of beperk1ngen die het onderscheid bezit, toe-
pasbaar op de sportsituatie.

Daarbif nemen we een aantal veronderstellingen van Ekkers (1975) over: reaktleve agressie is in de sport te onderscheiden van instrumentele agressie omdat ze

1. meestal geen direkte invloed heeft op het spelverloop,

2. meestal volgt (al dan niet onmidde1lijk) op een agressieve bejegening die wel invloed op het spel heeft. Als voorbeeld geeft hij het natrappen bij voetbal. 
Hij wijst erop dat instrumentele agressie, voor degene die er het slachtoffer van is, meestal een vrij ernstige frustratle betekent en konkludeert dat een belangrijk aspekt van instrumentele agressie is, dat het nieuwe (frustratie)agressie in de hand werkt. Het is hier overigens van belang op te merken dat onderzoek (Gabler, 1976; Voligt, 1982) uitwifst dat de struktuur van de sport niet alleen de kans bepaalt op overtredingen maar ook verantwoordelijk is voor de aard ervan.

Daarbij blijkt dat hoe liberaler de spelregels zijn, dat wil zeggen een ruime interpretatie door speler en scheidsrechter, des te groter de kans wordt op instrumentele overtredingen.

Sporten als volleybal en basketba1, die Voigt (1982) sporten met geformaliseerde interaktiestrukturen noemt, laten weinig instrumentele agressie toe.

\subsubsection{Definiëring van agressief gedrag}

Tot nu toe hebben wij geen standpunt ingenomen over de inhoud van het begrip agressie.

Daarvoor zijn twee redenen te geven:

- Ten eerste is uit dit hoofdstuk duidelijk geworden dat een definitie van agressie waarin ledereen zich kan vinden, onmogelijk zal zijn. Ekkers (1975) geeft terecht aan dat de inhoud ervan fluktueert in de tijd en per matschappelijke groepering; Hueting (1978b) merkt in dit opzlicht trouwens nog op dat poging tot een alomvattende definitie van agressie irritaties oproept vanwege de aanmatiging die een dergelijk streven bevat.

- Een tweede reden om het begrip agressie niet nauweurig te defintëren is een gevolg van de aard van ons onderzoeksmateriaal. Immers, het zijn scheidsrechters die strafzaken aamhangig maken; met andere woorden, wedstrijden waarin geen strafzaken voorkomen hoeven niet persé minder agressief te zijn dan wedstrijden met strafzaken.

Dit betekent dat wij, zonder preciese definiëring van agressie meer de contouren schetsen waarbinnen sprake kan $z 1 j n$ van agressief gedrag. 
De inhoud van agressief gedrag hangt af van kenmerken van de situatie.

De sportsituatie, als verbijzondering van 'n situatie, kent haar eigen regels en normen. Binnen de sportsituatie en zelfs binnen één sport zijn verschillende interpretaties van agressie aanwezig.

Vervolgens zifn binnen de sportsituatie, voor een bepaling van agressief gedrag drie elementen aanwezig:

- opzet

- schade

- in strijd met de sportieve norm

Geen of nauwelijks diskussie over het al dan niet agressief karakter zal er bestaan indien de overtreding dermate buiten het kader van het algemeen(!) aanvaardbare plaatsvindt; bijvoorbeeld het door "vriend en vijand" waargenomen slaan en/ of schoppen van de scheidsrechter; de diskussie zal juist dan gevoerd worden indien een van de door ons genoemde drie elementen minder duidelijk in het gedrag aanwezig is, en dat is bijna altijd het geval!

2.3 Agressieteorieën

Tot dusverre hebben wij ons nog niet afgevraagd warom personen agresslef gedrag vertonen. Daarom willen we enige teorieën behandelen die agressief gedrag pogen te verklaren; veel onderzoekers passen deze teorieèn ook op de sportsituatie toe.

Bij de bespreking van deze teorieèn gaan wij echter nog niet in op de eventuele toepasbarheid ervan op de sportsituatie. Deze relatie komt aan het eind van dit hoofdstuk in par. 2.6 .1 ter sprake.

Volgens Fris (1972) pogen de agressieteorieën meestal antwoord te geven op éen of meer van de volgende vragen:

- waarom gedraagt de mens $z i c h$ agressief;

- waarom gedraagt de ene zich agressiever dan de ander;

- waarom gedraagt dezelfde mens zich in de ene situatie agressiever dan in de andere situatie.

Het antwoord op deze vragen kan ons inziens tevens antwoord geven op onze probleemstelling warom in de ene wedstrijd we 1 en in de andere geen strafzaken voorkomen. 
We willen hier beginnen met het kort weergeven van een viertal gezichtspunten die vrij algemeen ter verklaring van agressief gedrag geciteerd worden. Deze teorleën echter moeten we niet beschouwen als elkaar uitsluitend. Ieder gezichtspunt zal in zekere zin het andere gedeeltelijk overlappen.

\subsubsection{Instinkt teorie}

Agressie is aangeboren en moet van tijd tot tijd ontladen worden (Katharsis). Vertegenwoordigers van deze theorie zijn o.a. Lorenz, Freud en Adler. De terminologie van de auteurs betreft vooral begrippen als instinkt en drift.

Bij Freud is de neiging tot agressie steeds aanwezig; bij Adler treedt agressie als driftmatig gedrag slechts op als andere behoeften onbevredigd blijven (Fris, 1972).

Tegen deze teorie zijn een aantal bezwaren geopperd. Eén van deze bezwaren is dat eksperimenteel onderzoek uitwijst dat het plegen van agressie de waarschijnlijkheid van agressief gedrag bij een volgende gelegenheid eerder vergroot dan verkleint (Ekkers, 1975; Rigauer, 1981). Coakley (1978) geeft o.a. als kritiek op de instinkt-teorie dat altijd gerefereerd wordt aan agressief gedrag van mannen, maar dat de rolpositie van de vrouw over het hoofd wordt gezien.

Naast deze bezwaren tegen de teorie, bestaat de moeilijkheid dat de agressieve neiging niet direkt meetbaar is, waardoor de voorspellende waarde van het model gering is; dit alles heeft ertoe geleid dat de energiemodellen warbij de agressieve neiging als aangeboren wordt beschouwd tegenwoordig niet meer worden gezien als bruikbare middelen bij het voorspellen en beheersen van agressief gedrag. "Vooral hun onvermogen om verschillen in agressief gedrag in verschillende situaties te voorspellen is hiervoor een belangrijke reden" (Ekkers, 1975).

\subsubsection{Frustratie - agressie teorle}

De kern van de frustratie-agressie teorie ( $f-a$ teorie) kan als volgt worden weergegeven: agressie is een reaktie op frustratie, waarbij onder frustratie wordt verstaan: blokkering van begonnen doelgericht gedrag. Dollard et. al. (1939) zijn vertegenwoordigers van deze richting. 
Deze teorie veronderstelt een direkt verband tussen frustratie (oorzaak) en agressie (gevolg).

Later is deze direkte relatie afgezwakt. Individuen hoeven niet persé agressief te reageren op een frustratie. Frustratie werd door sommigen gezien als een soort innerlijke opwinding; anderen, o.a. Berkowitz (1973), verstaan onder frustratie een aantasting van eergevoel of eigenwarde, terwijl door allerlei onderdrukkende, remmende, omstandigheden bijvoorbeeld de effektiviteit van het sanktiesysteem, de agressie geheel of gedeeltelijk achterwege kan blijven.

Het moge duide1ijk zijn dat door deze wijzigingen in het frustratie -agressie model er niet meer gesproken kan worden van een direkt verband, maar dat vele doorkruisende faktoren een rol kunnen spelen. Daarom wordt tegenwoordig gebruik gemakt van de term 'stimulus' om daarbij aan de oorzaak van agressie een ruimer kader te geven. Naast frustratie kunnen ook belediging, bedreiging, en aantasting van gevoel van eigenwaarde mogelijke stimulus faktoren zijn.

In deze terminologie, is agressie vervangen door de term response, ondat de hier genoemde stimuli niet persé tot agressief gedrag hoeven te leiden.

Gedrag dat veelal met de f-a teorie in verband wordt gebracht is de reeds door ons besproken, reaktleve agressie: agressie als gevolg van de een of andere als onaangenaam ervaren stimulus en primair gericht op het kwetsen van degene die als oorzaak van de onaangename stimulus wordt gezien of daarmee wordt geassocieerd (Ekkers, 1977).

of de frustratie tot agressief gedrag aanleiding zal geven is afhankelijk van een aantal faktoren warvan o.a. Mulder (1972) er enige opsomt: beschikbaarheid van niet-agressieve reaktles van het individu of de situatie; de sterkte van de gefrustreerde doelgerlchtheid; de aantasting van het soort gevoel b1j betrokkene( $n)$; de onderdrukking, of verdringingsmechanismen van frustratie; voorafgaande ervaringen (hoe vaak aangevallen of uitgedaagd); ervaringen na agressief gedrag in het verleden (mate en frekwentie van beloning en straf); sociale vergemakkelijking (sub-kulturele normen); persoonskenmerken.

Mulder vervolgt, dat, indien zoveel kondities in aanmerking dienen te worden genomen, de frustratie-agressie hypothese in haar eenzijdigheid niet kan worden geaksepteerd als een afdoende verklaringsmogeli jkheid. 
Naast het bezwaar dat er geen direkte relatie bestat tussen frustratie en agressie bestaat er nog een ander bezwaar tegen deze teorie.

De teorie geeft in feite alleen aan dat in bepalde situaties agressie kan optreden maar lat de waarom-vraag van agressie onbeantwoord. (Pilz, 1976, Bandura, 1978).

Volgens Bandura vervangt frustratie het begrip instinkt als de aktiverende bron, mar de 2 teorieën zijn bijna gelijk in hun sociale implikaties. Frustratie boort een agressieve impuls aan die op haar beurt motiveert tot agressief gedrag. Als laatste beperking van de $\mathrm{f}$-a teorle kan gelden dat een aantal vormen van agresslef gedrag niet wordt verklaard; men doelt met name op de zogenaamde instrumentele agressie warbij geen onaangename stimuli een rol spelen (zie par. $2.3 .3)$.

\subsubsection{Leerteorie}

Agressle wordt gezlen als een vorm van (aan)geleerd gedrag. Bif het leren, spelen twee aspekten een belangrijke ro1:

1. leren door imitatie (Bandura, 1973; Fris, 1972) via a. observatie, waarbij van belang is dat men er aandacht voor heeft, het geobserveerde moet onthouden en kunnen uitvoeren. Om dit te bewerkstelligen moeten er versterkende en motivationele processen aanwezig zijn.

b. direkte ervaring;

Bandura noemt 3 bronnen: gezin, subkultuur en massamedia.

2. Leren door positieve en negatieve gevolgen, met andere woorden, door beloning of straf. Het onderscheid dat we gehanteerd hebben bij punt 1 kunnen we ook hier maken. Dit betekent dat men gedrag en de gevolgen van anderen observeert (de indirekte beloning) of men evalueert het eigen gedrag (de direkte beloning) (Bandura, 1973).

Een vorm van agressie die met de leerteorie in verband wordt gebracht is de zogenaamde instrumentele agressle. Overigens de door ons besproken symboliese agressie (bijvoorbeeld het met de vinger naar het voorhoofd wijzen) heeft bil uitstek een leerteoretiese grondslag.

De leerteorie kan volgens Cauwels (1977d), de agressiviteit niet volledig verklaren. Belangrifke biologlese, fysiologiese, historiese, politieke, ekonomiese en sociologiese probleemstellingen worden er nauwelijks in betrokken. 


\subsubsection{Emotie en aktivatieteorie}

Ekkers (1977) noemt twee teoretiese opvattingen ten aanzien van de relatie fyslologiese aktivatie en agressief gedrag:

1) de teorie van de direkte facilitatie, welke gebaseerd is op de algemene gedragsteorie van Hull. Voor het optreden van een agressiewe respons op een bepald moment is nodig dat de persoon zich in een fysiologlese toestand van aktivatie moet bevinden èn agressie moet tot zijn gedragsrepertoire behoren, met andere woorden moet dominant zijn (de Ridder, 1980). Ekkers (1977) maakt dulde$11 \mathrm{jk}$ dat $0 . a$. Berkowitz de stimulanskant benadrukt, agressle komt alléen voor indien bepalde cues (stimuli) aanwezig zijn; Bandura beklemtoont de responsekant; men reageert met bepaald gedrag dat men geleerd heeft. Vooral deze laatste stellingname is leerteoreties.

2) de twee faktorteorie (van Tannennbaum en Zillmann), waar bij twee elementen belangrijk zijn

a) het reeds aanwezig $z 1 j n$ van een emotionele toestand van kwaadheld is een noodzakelijke voorwaarde om additionele fysiologiese aktivatieverhoging een agressleverhogend effekt te laten hebben;

b) de oorzaak waaran het individu de additionele aktivatie toeschrijft; schrijft hij het toe aan zijn reeds bestaande toestand van kwaadheid of aan de oorzaak van de kwaadheid dan kan deze toestand van kwaadheid geIntensiveerd worden en tot agressie lelden.

Het vermoeden bestaat dat nlet alleen reaktief agressief gedrag maar ook niet emotioneel, instrumenteel agressief gedrag door aktivatieverhoging versterkt kan worden (Ekkers, 1980).

Ook ult paragraaf 2.3 . is duldelijk geworden, dat, als we het begrip agressle en de teorleën daarover willen toepassen op de sportsituatie we eerst duidelijk moeten maken wat deze situatie feitelijk inhoudt. Daarbij zullen we ons, gezien het onderzoeksmateriaal, thet name richten op de situatie in de voetbalsport. 
2.4. De sportsituatie

aanvoerder gestrafte partiJ:

"Speler $x$ is tijdens de wedstrijd altijd arg emotioneel."

scheidsrechter:

"... na de wedstrijd is hij nog bil mij geweest;

Ik heb hem toen gezegd dat lk veel kan verdragen maar dat ik me nlet voor lul laat ultmaken. Dit kon hij dan cok na de wedstrijd pas begrijpen. Maar dit is altijd zo."

\subsubsection{Algemeen}

De sportsituatie kan men beschouwen als een soclale enclave waarin andere regels en normen gelden als in het dagelijks leven. Echter, de sportsituatie kan niet strikt gescheiden worden van de dagelijkse situatie: de autonomie van spelsituaties is in werkelijkheid altijd betrekkelijk (Stokvis, 1979).

Basiselementen van sport zijn o.a. prestatie en wedijuer. Het "winnen" neemt daarbij een centrale plaats in (Russe1, 1983).

$\mathrm{Nu}$ is het een algemeen verschijnsel dat sommigen zich in de sport anders gedragen dan in het "maatschappelijk leven". Talloze voorbeelden zijn te geven van sporters die bekennen zich, op bijvoorbeeld het voetbalveld, agressiever te gedragen. De slechte verliezer, als voorbeeld, komt in alle sporten voor. Zij zijn in feite verslaafd. Uit sociologies gezichtspunt betekent dit het verdringen van de strukturen en de zin die men aan het bestaan had gegeven door overdreven aandacht te schenken aan éen bepaalde handeling (Philipsen, 1976).

Hoewel veel gesproken wordt over "de" agressie in "de" sport is ons inziens deze uitspraak te algemeen en dus ongenuanceerd. Immers, de uitspraak gaat voorbij aan de verschillende vormen van agressie en de verschillende takken van sport. De diskussie omtrent agressie in de sport wordt juist daar 
gevoerd waar een bepaalde vorm van agressie als probleem wordt ervaren. Met name wordt hedentendage de aandacht gericht op die sporten warin de drie elementen van agressief gedrag opzet, schade en in strijd met de sportieve normen duidelijk aanwezlg blijken te zijn. Een door velen ingenomen standpunt is dat agressie in de sport verband houdt met de struktuur van de sport (o.a. Bredemeier, 1983; Gabler, 1976; Pilz, 1974; Schmidt, 1978; Simons, 1972; Voigt, 1982; Volkamer, 1971).

De struktuur wordt bepald door de spelregels.

Omdat fysieke agressie nu eenmal als ernstiger wordt beschouwd als verbale of symboliese agressie, betekent dit dat met name in die sporten agressie als probleem wordt ervaren waarin gelegenheid tot lichamelijk kontakt aanwezig is.

Ekkers (1975) veronderstelt dat het toestaan van lichamelijk kontakt betekent het toestaan wan een zekere hoeveelheid agressie.

Bij deze konstatering zijn twee nuanceringen op zijn plaats. Allereerst betekent het niet dat de zogenaamde niet kontaktsporten geen agressief gedrag kennen; schaaktweekampen op topnivo worden bijvoorbeeld veelvuldig afgewerkt in een sfeer van pesterijen en verdachtmakingen van de spelers ten opzichte van elkaar en betekenen het aanwezig zijn van voora1 symboliese agressie.

Een tweede opmerking is dat ook binnen de kontaktsporten gedifferentieerd moet worden naar tak van sport.

Sporten als judo, worstelen en boksen zouden zonder lichamelijk kontakt niet kunnen bestaan; desondanks is de fysieke schade die bij deze sporten kan optreden meestal niet als gevolg van agressief gedrag te beschouwen.

De knock-out bij boksen is immers niet een gevolg van gedrag dat in strijd is met de sportieve norm! Het is daarom ook typerend dat in de diskussie omtrent agressie als probleem de bokssport als zodanig ter diskussie staat.

Konklusie van bovenstaande is dat we pas dan over agressief gedrag in de sportsituatie kunnen spreken en oordelen als we de sporttak en haar regels kennen. Op hun beurt bepalen de regels welke sankties worden toegepast als de regels overtreden worden. Daarom willen wij wat nader ingaan op spelregels en sankties in de voetbalsport. 


\subsubsection{Spelregels en sankties in de voetbalsport}

\subsubsection{Spelregels}

Histories gezlen zijn in het voetbal in 1845 de ongeschreven gewoonteregels tot formeel geschreven regels geworden (Dunning, 1976, 1983); in de loop der tijd zijn deze regels uitgebreid en aangevuld. De funktie van de scheidsrechter, bljwoorbeeld, werd in 1881 voor het eerst formeel vastgelegd (Albrecht en Musah1, 1979a). Het ontstaan van de strafschop (1891) en 10 jaar later van het strafschoppunt waren andere belangwekkende toevoegingen (KNVB, 1980). (Tot 1901 mocht de strafschop worden genomen van een willekeurige plaats zoveel meter van het doel.)

Op het ogenblik bestat een zeventiental spelregels. Zowel Searle (Albrecht en Musah1, 1979a) als Vaz (1979) maken een onderscheid tussen konstruktieve regels die het raamwerk van het spel vormen (veldafmetingen, duur spel, grootte der teams, enz.) en regulatieve regels die zlch kenmerken door imperatieven, dat wil zeggen het normatieve raamwerk waarin de sankties passen.

Het ontstaan van spelregels heeft er, volgens o.a. E1ias (1976) en Dunning (1983), toe geleid dat de sport meer kompetitief is geworden; meer kompetitie betekent een grotere nadruk op winst. Dit betekent weer dat het belang van het winnen, spelers ertoe zal brengen deze winst ten kaste van overtredingen, dus agresslef gedrag te berelken.

gestrafte speler:

"Ik hield mijn tegenstander vast om met de bal op doel af te gaan. Dit mag nilet, dat weat lk, mar wij voetballen allemal om te winnen en dan worden or middelen gebrulkt die bestraft worden, af en toe."

Daarnaast blijkt het kompetitie-element in sterkere mate, gevoelens van wantrouwen en een vijandige houding jegens de tegenpartij op te roepen dan het geval is bij groepen die samenwerken (Snijders, 1982). Gaskel1 (1979) neemt in dit opzicht aan dat kompetitieve sport in het bijzonder geschikt is voor geritualiseerde agressie. 
Eén van de spelregels die veelvuldig aanlelding geeft tot diskussie is het, in sommige situaties toestaan van lichame11 jk kontakt.

Naast de gelegenheld tot lichamelijk kontakt in de voetba1sport is dit kontakt, indien toegepast, in veel gevallen uiterst funktioneel, zowel binnen als buiten de regels. Gabler (1976) geeft hiervoor een "techniese" verklaring: in tegenstelling tot bij handbalsporten is de bal moeilijk(er) onder kontrole te houden; dit betekent dat de medespeler een grotere kans heeft de bal te ontfutselen. Met andere woorden het 1ichamelijk kontakt heeft een funktie in het spel.

Daarnaast zijn talloze voorbeelden bekend van het funktioneel zijn van lichamelijk kontakt buiten de regels: het blokkeren van een tegenstander die "dreigt" door te breken of het neerleggen van een tegenstander in een goede skoringspositie, de zogenaamde professionele overtredingen.

Ekkers (1975) konkludeert dat de gelegenheid én instrumentele waarde van de agressie in veel empiriese onderzoekingen voldoende voorwaarde $z i j n$ voor het ontstaan van agressief gedrag.

Het gegeven dat agressie in de voetbalsport als probleem wordt ervaren wordt nog benadrukt door het groot aantal letsels dat in deze sport voorkomt (Kranenborg, 1980a; WVC, 1985).

Hoewel in de inleiding reeds is vermeld dat het begaan van overtredingen niet noodzakelijkerwijs hoeft te leiden tot het vббrkomen van blessures, bestaat een algemene mening dat een deel van de blessures wel door fysieke overtredingen wordt veroorzaakt.

Bif de overweging om overtredingen te begaan speelt, naast de gelegenheid en het instrumentele karakter van het 1ichamelifke kontakt nog een aspekt een rol: weegt het voordeel van de overtreding op tegen het nadeel van de eventuele straf.

op dit sanktieaspekt willen we hier wat nader ingaan.

\subsubsection{Sankties}

Bif de diskussie over de inhoud van agressief gedrag is opgemerkt dat opzet vaak moellijk te bewljzen valt.

Er doen zich problemen voor die vergelijkbaar $z i j n$ met het bewljs van het bestanddeel opzet in strafrechtelijke $z$ in (vgl. Hazewinke1-Suringa, 1984). 
Het al dan niet opzettelijk $z$ ijn van overtredingen is, volgens het Handboek voor de scheidsrechters (KNVB, 1980), het allesbeheersende punt van de regel overtredingen en wangedrag; de overtreding moet met opzet worden begaan om strafbaar te zijn. Letterlijk betekent opzet (volgens het zojuist geciteerde Handboek) "met voorbedachten rade". Een benoeming overigens die strafrechtelijk niet juist is. Het valt echter buiten het kader van dit verslag hierop meer uitgebreid in te gaan (zle hlervoor 0.a. Hazewinkel-Suringa, 1984).

Met andere woorden, een scheidsrechter kan pas dan tot een sanktie overgaan indien voor hem opzet bewezen is.

Kranenborg (1980b) konkludeert uit een onderzoek onder afdelingsscheidsrechters dat $60 \%$ het moeilijk vindt te beoordelen of een overtreding opzettelijk is of niet.

Ekkers en Hoefnagels (1972) konkluderen over het begrip opzet dat de scheidsrechter als het ware in de vaart van het spel intrapsychies kijkt en dit moraliseert. Zij geven aan dat een intentie-moral bij de beoordeling van overtredingen op het veld dysfunktioneel werkt; niet het opzet mar het gevolg van de handeling is relevant. Het zal volgens hen een aanvaller een zorg zijn of hij op het punt van skoren met of zonder opzet onderuit wordt gehald.

In hoofdstuk 1 is vermeld welke sanktles de scheidsrechter in een wedstrijd ter beschikking staan. De regulatieve spe1regels zijn door verscheidene onderzoekers ook weer onderverdeeld.

Ekkers (1975) maakt een onderscheid tussen spelsankties, die onmiddellijk na de overtreding door de scheidsrechter worden. gegeven en direkt invloed hebben op het spel, bijvoorbeeld de strafschop, de vrije schop en het uit het veld sturen, en uitgestelde sankties die meestal wel onmiddelijjk na de overtreding gegeven worden, mar geen direkte invloed op het spelverloop hebben (de officiele waarschuwing).

In het onderscheid van Ekkers zouden we beter kunnen spreken van spelsankties, met gevolgen voor het spe1, en spelerssankties, met gevolgen voor de spelers. De officlele waarschuwing en het uit het veld sturen hebben in zekere zin betekenis voor én het spel, immers het spe1 wordt stilgelegd voor het opleggen van de offlciele straf én de speler. De tuchtkommissie beraadt zich dan naderhand nog op een sanktie boven op de scheidsrechterlijke sanktie.

Het aantal scheidsrechterlijke sankties per wedstr1jd loopt uiteraard utteen. 
V.d. Brug (1980) en Gabler (1976) komen tot gemiddeld respektievelljk 31 en 36 gesanktioneerde overtredingen per wedstrijd. Begerau (1981) analyseerde 9 thuiswedstrijden van é̉n elftal; 3 "objektieve" waarnemers komen (na het zien van de video-beelden) tot 678 overtredingen gemiddeld 75 overtredingen per wedstrijd; de scheidsrechters gaven in totaal 120 vrije schoppen voor overtredingen; verschillen die laten zien inhoeverre laboratium- van veldsituaties kunnen afwijken.

In hoofdstuk 1 is al vermeld dat de overtredingen die tot strafzaken leiden (waarschuwingen en uit het veld zendingen) in verhouding tot de andere sankties de top van de ijsberg vertegenwoordigen.

Over het algemeen is de (In)direkte vrije schop de meest gebrulkte scheidsrechterlijke sanktie. Zowel Ekkers en Hoefnagels (1972) als Kranenborg (1980b) geloven dat de vrije schop lonend werkt; immers dit betekent spelonderbreking, waarbij de posities op het veld gekorrigeerd kunnen worden; van lets dat lonend werkt kan herhaling verwacht worden. Ekkers en Hoefnagels konkluderen hieruit dat dit eén van de redenen is waarom spelers in een situatie zijn geraakt waarin $z i j$ voortdurend aan de overweging tot overtredingen toekomen.

Wanneer we na wllen gaan of sanktiles effektief zijn, dus remmend werken op het begaan van overtredingen, kunnen we allereerst refereren aan enkele algemene bevindingen uit leerpsychologiese onderzoeken over de toepassing en werking van straffen (Hoefnagels, 1980):

1. een straf die niet onmiddellijk op de overtreding volgt is minder effektief dan een onmiddellijke straf

2. de straf werkt slechts korte tijd en dan nog alleen als er konslstent en adekwaat gestraft wordt;

3. een straf heeft ongewenste neveneffekten:

a. ontwikkeling van ongewenste methoden tot verbergen, ontwijken van de overtreding,

b. ontstaan van ongewenste emotionele, met name agressleve responses,

c. straffer gat fungeren als agressie-objekt;

4. straf werkt niet norm-internaliserend;

5. straf generaliseert niet en kan alleen maar preventief werken ten aanzien van de specifleke overtreding, niet ten aanzien van soortgelifke overtredingen;

6. voorwaarde voor werking van de straf is dat de straf zelf onverenigbaar is met het voordeel van de overtreding. 
Het zal duidelijk zijn dat de meest gebruikte scheidsrechterlijke sanktle, de vrije schop niet verenigbaar is met punt 6. Ekkers en Hoefnagels (1972) maken duidelijk dat, wanneer men een overtreding begaat door bijvoorbeeld het onderuithalen vlak voor het strafschopgebied, de sanktie vrije schop betekent dat het elftal zich kan reorganiseren en $z 1 j n$ nadelige positie kan herstellen; dat wil zeggen de zogenaamde negatieve sanktle blijkt een positieve te zijn.

In deze situaties heeft instrumentele agressie een nuttig effekt.

Indien we de vorige paragraaf samenvatten dan kunnen we vaststellen dat de voetbalsport spelregels bezlt die:

- in sommige situaties lichamelijk kontakt niet steeds verbieden,

- interpretatiemogelijkheid bieden voor de scheidsrechter (opzet),

- zorgen voor weinig effektieve sankties,

Daardoor ontstaat een klimaat warin het toestaan van 11 chamelijk kontakt de kans op agressief gedrag vergroot en de sankties met name zorgen voor een gerede kans op instrumenteel agresslef gedrag.

\subsection{Positie en rol van de scheidsrechter}

Spelregels en sankties worden toegepast door de scheidsrechter (met assistentie van twee grensrechters). Wellicht had het meer voor de hand gelegen als we eerst de rol en positie van de scheidsrechter besproken hadden en daarna waren ingegaan op de hem ter beschikking staande sankties.

Bewust is echter voor deze opbouw gekazen om daarmee tot uitdrukking te brengen dat we de scheidsrechter vanuit een andere teoretiese invalshoek benaderen.

Tot dusverre is in dit hoofdstuk immers het gedrag van de spelers gerelateerd aan het begrip agressie en de aan dit begrip gerelateerde teorfeën.

Ons onderzoek baseert zich echter op gegevens die afkomstig $z 1 j n$ van de scheidsrechter, namelijk de door hem waargenomen en als zodanig bestrafte overtredingen. In strikte zin is (Gabler, 1976) in een dergelijk onderzoek niet het gedrag van spelers onderwerp van onderzoek, maar de gedragsbeoordeling van hen door scheidsrechters. Ekkers en Hoefnagels 
(1972) drukken dit als volgt uit: scheidsrechterlijke rapporten vormen een afspiegeling van zowel feitelijke gebeurtenlssen, als het opsporings-, aanhoudings- en bestraffingsbeleld van de verschlllende scheidsrechters. Het voorbeeld van Ekkers en Hoefnagels makt duidelijk dat onderscheid dient te worden gemakt tussen feltelijk afwijkend gedrag en afwijkend geregistreerd gedrag. De laatste vorm wordt ook wel aangeduid als "rate producing behavior" of "rate producing processes" (Drop, 1972; McCarty, 1976). Bij met name gedrag dat inhoudelijk moellijk te definieren valt, met andere woorden, war interpretatie van de situatie een belangrijke rol speelt komt "rate producing behavior" voor; bij ultstek geldt dit voor afwijkend gedrag, bijvoorbeeld gespecificeerd in agressief gedrag in de voetbalsport.

Afwijkend geregistreerd gedrag vindt bijvoorbeeld in de voetbalsport op verschillende nivos plaats: allereerst worden international de spelregels en sankties vastgesteld; nationaal gezien kunnen per seizoen richtlijnen aan scheidsrechters worden gegeven, door bij het sanktiebeleid op bepalde overtredingen ekstra te letten; tenslotte, is de scheldsrechter zelf een belangrijke "cijfer-producerende" instantie.

Daarom, en wif zullen dit in het verloop van dit verslag blijven herhalen, dient men zich voortdurend af te vragen wat in feite de inhoud is van het onderzoeksmateriaal.

Onze teoretiese benadering van de scheidsrechter wordt verklaard vanult de aard van ons onderzoeksmateriaal. In hoofdstuk 1 is reeds vermeld dat in het afdelingsvoetbal, door het tekort aan officlele scheidsrechters, niet-officiële dit tekort moeten aanvullen. $+40 \%$ Van de wedstrijden wordt door deze niet-offictëlen geleid. Het is dit verschil, dat wij voortaan zullen uitdrukken als het verschil in status scheidsrechter, dat als handvat heeft gediend voor de teoretiese Invalshoek. Deze teoretiese benadering geeft in felte een kombinatie van twee gezichtspunten weer. We zullen met name aandacht besteden aan de rol van de voetbalscheidsrechter en de rolkonflikten warmee hij te maken heeft. De uitoefening van deze rol wordt ons inziens beinvloed door de kennis van spelregels en ervaring met het leiden van voetbalwedstrijden. Met andere woorden aspekten van de rolteorie en van de cognitieve teorieën (Mccrimmon en Taylor, 1976; Zajonc, 1968), waarin begrippen als kennis en ervaring passen zullen in het hierna volgende aan bod komen. 
De scheidsrechter is formeel gezagsdrager, ordehandhaver en heeft in het uitoefenen van zijn funktie de beschikking over de door de voetbalbond geleverde spelregels en sankties. Eckhoff (1971) maakt een onderscheid in drie soorten "derden", personen, of instituties die in een konflikt tussen twee partijen een bemiddelende rol spelen.

De eerste soort noemt hij de "bemiddelaars" (mediators) zij werken met de partijen gezamenlijk naar een oplossing; de tweede soort betreft de "rechters" (judges), zij beslissen in een konflikt wie de regels of normen van de situatie in aanmerking nemend, gelijk heeft; tenslotte, de derde soort, de "administrateurs" (administrators) die evenals de rechters een beslissing nemen in het konflikt, maar de mogelijkheid hebben de regels te veranderen of aan te passen. $\mathbb{P i l z}$ en Trebels (1976) passen het onderscheid van Eckhoff toe op de sportsituatie. Scheldsrechters behoren in hun visie tot de rechters, terwijl de sportbond de funktie van administrateur bezit.

Met de verwijzing naar Eckhoff, en Pilz en Trebels, w1llen we duidelijk maken dat de positie van de scheidsrechter maukeurig omschreven is: ten opzichte van de bond staat de voetbalscheidsrechter in een ondergeschikte positie en ten aanzien van de spelers in een bovengeschikte positie.

De Handleiding voor Scheidsrechters (KNVB, 1980) noemt de scheidsrechter de man die in het veld de beslissingen neemt. Inspraak is in de sfeer van een voetbalwedstrijd volgens dit handboek geen bruikbaar begrip.

Hoewel zijn positie voor zowel de officiële als niet-officiële scheidsrechter dus duidelijk is, is zijn rol, het geheel van normen en verwachtingen dat men koestert jegens personen in een bepalde positle (van Doorn en Lammers, 1973) minder duidelifk. Deze onduidelijkheid wordt door een aantal faktoren bepaald:

De scheidsrechter heeft inherent aan de scheidsrechtersfunktle te maken met een rolkonflikt. Dit konflikt wordt ons inziens in het voetbal nog versterkt door de voetbalspelregels. Daarbij, en dit aspekt is specifiek voor ons onderzoeksmaterial, vindt er voor de niet-offlcièle scheldsrechter nog een ekstra versterking van het rolkonflikt plaats. De hierbovengenoemde punten willen we nu verder uitwerken. 
- De scheldsrechtersrol betekent per definitie het bestaan van een intern rolkonflikt.

Alle scheldsrechters hebben, bif het leiden van wedstrijden te maken met twee partijen die veelal onverenigbare eisen ten aanzien van zijn rol stellen. Iedere partij definieert een bepalde spelsituatie in har voordeel. Elke beslissing in het voordeel van de een werkt in het nadeel van de ander. Kognitleve teorleën leren ons dat beslissingen die onvoorzlene gevolgen kunnen hebben niet genomen of uitgesteld worden; men streeft naar een balans (konsonantle) en vermijdt dissonantle-producerende gebeurtenissen.

De niet-officiele scheidsrechter zal trachten zoveel mogelifk de balans, beginsituatie, in evenwicht te houden. Met andere woorden hij neemt geen beslissing of stelt ze zoveel mogelijk uit.

- De kans op een intern rolkonflikt wordt in het voetbal nog versterkt door de niet eenduldige interpretatie van de spelregels, en het gegeven dat een scheidsrechter, als enige tijdens de wedstrijd beslissingsbevoegdheid heeft.

Deze versterking van het rolkonflikt werkt vanuit twee richtingen.

Vanult de spelers bezien dienen interpretatieproblemen van de spelregels (al dan nlet opzet; lichamelijk kontakt) in sommige situaties vaak als voedingsbodem voor de tegengestelde eisen warmee ze de scheidsrechter konfronteren.

Ook vanuit de scheldsrechters bezlen versterken de spelregels de kans op een rolkonflikt. Er is in tegenstelling tot vele andere takken van sport, slechts één scheidsrechter die beslissingsbevoegdheid heeft. De scheidsrechterspositie bezit een cumulatie van taken: waarnemen, toetsen aan de spe1regels, al dan niet opleggen van sanktles en de keuze ervan (Ekkers en Hoefnagels, 1972).

Kranenborg (1980b) heeft een aantal afdelingsscheidsrechters (ult Zuid-Limburg) 0.a. gevraagd naar de beoordelingsproblematiek op het veld; $85 \%$ van hen is het er mee eens dat het voor een scheldsrechter een ondoenlijke zaak is alle situaties goed te beoordelen.

Het waarnemen en beslissen in spelsituaties is ons inziens mede afhankelijk van kennis en ervaring en derhalve te relateren aan het onderscheid officiële - niet-officiële scheidsrechter. 
Cognitieve teorieën leren ons dat herhalde cognitieve ervaringen ertoe leiden dat de persoon een groot aantal psychologiese dimensies verwerft, dat wil zeggen een grotere set van attributen; de totale set van alle attributen vormt zifn kognitief universum; officiele scheidsrechters zijn in tegenstelling tot wedstrifdleiders getraind via de scheidsrechterskursus en middels wedstrijden, bepaalde spelsituaties war te nemen en daarin beslissingen te nemen.

- Ons onderzoeksmateriaal, met name het onderscheid dat we kunnen maken tussen officlële en niet-officiële scheidsrechters, geeft ons aanleiding nog een vorm van een rolkonflikt te signaleren, dat in feite het interne rolkonflikt van de niet-officiële scheidsrechters versterkt. De niet-officiële scheidsrechter wordt door de thulsklub aangewezen en is meestal lid van de thuisspelende vereniging; aan de ene kant moet hij als gezagsdrager iedereen bestraffen die de spelregels overtreedt, aan de andere kant zullen de thuisspelers van hem verwachten dat hif in ieder geval hén niet straft.

Een van de aspekten die in cognitieve teorieèn aan de orde komt is, dat individuen die anderen straffen, wanneer $z i j$ de ander goed kennen een dissonantie ervaren; in de scheldsrechterssituatie betekent dit dat de wedstrijdleider, behorend tot de thuisklub deze dissonantie vooral ten aanzien van de thuisspelers zal ervaren en hen minder snel zal straffen. Deze dissonantle werkt wederkerig. Ook spelers zullen wanneer zij door een "goede kennis" gestraft worden deze dissonantie ervaren, immers juist van deze persoon wordt geen strafoplegging verwacht!

- Naast het interne rolkonflikt zorgt de scheidsrechtersrol tevens voor een ekstern rolkonflikt. Vanult de bond wordt verwacht dat hij de regels strikt doet naleven; echter in het veld is er vaak sprake van normen die afwijken van de spelregels (Gabler, 1976). In deze betekenis wordt de scheidsrechter bijwoorbeeld door de spelers verweten "de wedstrifd niet aan te voelen" of de "wedstrijd dood te fluiten". Dit betekent dat een scheidsrechter enlge ervaring moet hebben in het leiden van wedstrijden om te beseffen wat er onder de spelers "leeft"; dit kan er toe leiden dat nietofflciële scheidsrechters, meer in konflikt kunnen komen met de spelers. Dit rekening houden met de spelersnormen zal ons inzlens door de onervaren niet-officièle scheidsrechter minder gebeuren. 
- Een laatste aspekt dat in feite losstaat van de voorgaande opmerkingen over het begrip rol en de rolkonflikten, maar wel verband houdt met de status van de scheldsrechter en dat tevens in de cognitleve teorieën aan de orde komt is het volgende

De betekenis of het belang van bepaalde stimuli voor een persoon heeft konsekwenties voor $z i j n$ reaktie.

Vertaald naar ons onderzoeksmateriaal betekent dit dat de gebeurtenissen op het veld voor de wedstrijdleider een andere betekents hebben dan voor de officiële scheidsrechter.

Van deze laatste kategorie kan men redelijkerwijs verwachten dat $z \mathbb{1 j}$ trachten het beeld te bevestigen van de door de voetbalbond gepropageerde goede scheldsrechter; het is voor hen Immers van belang een wedstrijd goed te leiden omdat ze vaak bezig zijn met het opbouwen van een scheidsrechterskarrière en (daarmee samenhangend) beoordeeld worden door rapporteurs langs de lijn. Het feit overigens dat er rapporteurs aanwezig kumnen $z 1 j n$ wordt veelal niet voor de wedstrijd aan de scheidsrechters bekend gemaakt. In die zin kan een vergelijking worden getrokken met het onderzoek van Lammers naar de inlifving van groepen adspirant-officieren in de zeemacht (Lammers, 1963).

Adspirant-officieren geven namelijk te kennen dat zif strenger zullen reageren op overtredingen (indien ze daartoe in de gelegenheld gesteld worden) indien een officier van dienst verondersteld wordt in de buurt te $z i j n$.

Toegepast op de status van de scheidsrechter zou dit betekenen dat de officiêle scheldsrechter, mér dan de wedstrijdlelder zich zal konformeren aan de regels van de Bond (hij is immers officieel verlengstuk van de organisatie), en strikter de regels zal toepassen.

Tot nu toe zijn we bij de bespreklng van de status van de scheldsrechter vrijwel volledig uitgegaan wan het veronderstelde gedrag van de scheidsrechter. Tenslotte willen we benadrukken dat ook de spelers zich anders kunnen gedragen in het veld, afhankelijk van het felt of een officlèle dan wel nuet-oficiele scheidsrechter de wedstrijd leidt. Pilz (1976) bespreekt een eksperiment met wedstrijden zonder scheidsrechter. In deze wedstrijden oordeelden spelers positiever over de sfeer en vriendschappelijkheld ervan dan over wedstrijden geleid door scheidsrechters. 
Het is ons inziens mogelijk dat het aanstellen van een nietofficièle scheidsrechter een bepalde ekstra verantwoorde11 jkheid bij de spelers legt om de wedstrifd volgens de regels van het spel te spelen; een officièle scheldsrechter zou, wanneer we in deze trant doorredeneren, meer gezien kunnen worden als de officiêle gezagsdrager. Spelers kunnen in die $z$ in de scheidsrechter uittesten om na te gaan of te ondervinden "hoe ver ze kunnen gaan". Lammers (1963) geeft een analoog voorbeeld: volgens de normen van de schoolklas op de middelbare school is spieken in de aanwezigheid van de leraar sportiever en minder afkeurenswaardig dan spieken tijdens diens afwezigheid.

De in deze paragraaf behandelde gezichtspunten kunnen, en in felte is dit al tussen de regels door aangegeven, resulteren in een aantal hypothesen over de samenhang tussen de status van de scheidsrechter en de kans op en de aard van de scheidsrechterlijke sankties.

Tesamen met de veronderstellingen ten aanzien van de werking van de andere variabelen zullen wij deze hypothese in hoofdstuk 4 behandelen.

\subsection{Konklusies}

2.6.1. Zijn de agressleteorleën toepasbaar op de sportsituatle.

Tot nu toe zijn we in dit hoofdstuk nog niet ingegaan op de mate van toepasbaarheid van de verschillende agressieteorieën op de sportsituatie; zijn deze teorieën in het kader van onze probleemstellingen hanteerbare instrumenten? Deze vraagstelling willen wij voor iedere teorie afzonderlijk behandelen.

Wat de instinkt-teorie betreft, deze is voor ons onderzoek niet geschikt, omdat zij niet in staat is onze probleemstelling te beantwoorden waarom in sommige wedstrijden wel en in andere geen strafzaken voorkomen.

Niet alleen is de teorie niet geschikt om verschillen in agressief gedrag in verschillende situaties te voorspellen, maar zelfs bij toetsing blijkt dat sporters in tegenstelling tot de verwachting van de catharsis-teorie, na de wedstrijd meer agressief gedrag kunnen vertonen (Bandura, 1973). 
De enige variabele die in ons onderzoeksmateriaal met deze teorie verbonden kan worden is het tijdstip van de overtreding.

Omdat echter, in de meeste gevallen pas dan strafzaken aanhangig worden gemaakt indien spelers herhaldelijk de regels hebben overtreden, betekent dit per definitie dat de kans op strafzaken groter wordt naarmate de wedstrijd vordert; dit betekent dat de catharsis-teorie ook op deze onderzoeksvarlabele moellijk toepasbaar is.

Deze teorle zal derhalve in de volgende hoofdstukken niet meer ter sprake komen.

De frustratie-agressie- en emotie-aktivatie-teorie zijn in hun werking nlet strikt te schelden. Belde teorieën benadrukken de emotlonele kant van agressief gedrag. Bij de $f-a$ teorle gaat het om als onaangenaam ervaren stimuli, bij de emotie/aktivatie benadering om een kombinatie van allerlei onaangename ervaringen gekombineerd met aktivatieverhoging .

sicheldsrechter:

th... nadat de eerder genoemde strafschop genomen was, bleef men zlch van ....-zljde zeer provocerend gedragen, ook ten opzlchte van hun tegenstander."

scheidsrechter:

"na een door mil gegeven directe vrije trap tegen * wegens hands van hun doelman buiten het strafschopgebled ontstond aan $x-z \mid J$ de een geprlkkelde steming welke zich ontlaadde in enkele grove overtredlingen wan enkele spelers van $X$..."

gestrafte speler:

"er werd en corner getrapt en llep samen met tegenspeler naar binnen, toen $1 k$ stompen in mijn maag kreeg, aangeslagen door enotles maakte ilk de trappende beweging naar deze speler." 
In beide teorieën is overigens met name de laatste jaren (Ekkers, 1980) benadrukt dat zowel frustratie als alléén aktivatie instrumentele agressie kunnen veroorzaken; agressie is echter een van de vele gedragsmogelijkheden. Als men de frustratie-agressie niet belangrijk acht of als men geleerd heeft zich niet agressief te gedragen kan frustratie of emotie/aktivatie lelden tot bijvoorbeeld berusting. Hoewel we in ons onderzoek deze teorieển als sterk samenhangend zullen beschouwen willen we in het kort aangeven op welke wijze zij door verschillende auteurs toepasbaar wordt geacht op de sportsituatie.

De frustratie-agresste teorie

Sommigen de zgn. matschappij-kritiese school (Adorno, Habermas, Rigauer, Vinnai) gaan ervan uit dat in de sport agressie wordt afgereageerd, die in het dagelijks leven, bedoeld wordt met name de werk-situatie, geen uitweg kan, of mag vinden (met andere woorden geblokkeerd wordt). Deze afreageerfunktie van de sport kan men als positief waarderen of als negatief, dat wil zeggen het afreageren van agressie in de sport, betekent dat men zich in het alledaagse leven "rustig houdt". De agressie wordt gekanaliseerd en maatschappijhervormingen blijven achterwege (Vinnai, 1970). Guttmann (1981) weerlegt deze beweringen met de konstatering dat, en hij neemt het voorbeeld van de West-Duitse samenleving, de hogere sociale klassen, meer dan de lagere klassen, aan sport doen. Volgens hem is dit een duidelijk bewijs dat de sport geen repressiemiddel is, maar de gelegenheid bledt tot zelfrealisatie.

Naast deze uitleg van de frustratieteorie, zijn er onderzoekers die de teorie hanteren binnen de specifieke sportsituatie, dat wil zeggen zij zien de agressie als reaktie op frustrerende sportspecifieke voorwarden.

Zulke voorwaarden kunnen algemeen $z i j n, b 1 j$ voorbeeld dat spelers van verliezende teams meer agressle zouden plegen als spelers van winnende teams (de nederlaag is hierbij de verwoording van de frustratie); zle Volkamer (1972a).

Naast deze zogenaamde algemene situatie, geldend voor een geheel team, zijn er ook meer specifleke momenten in een wedstrijd die frustrerend kunnen werken op spelers b1nnen een team bijvoorbeeld de voortdurende konfrontatie met een onsportief spelende tegenstander. 
De emotie-aktivatie teorle

Ekkers (1980) stelt dat allerlei onaangename ervaringen (nederlaag, verkeerde beslissing scheidsrechter, het slachtoffer $z i j$ van een gewelddadige overtreding bij het individu) een emotionele toestand van kwaadheid of woede opwekken. Als verklaring echter voor de heftigheid van reakties is dit niet voldoende. In de sportsituatie bestaat een aantal aktiverende invloeden (lichamelijke inspanning, publiek) die op zich nlets met de emotionele toestand van kwaadheid te maken hebben, maar deze wel kunnen versterken. De op zich neutrale aktivatieverhoging (verhoging hartslag, bloeddruk, hersenaktiviteft, hormoonafscheiding) zou de door de onaangename ervaring ontstane emotionele toestand zodanig versterken, dat ekstreem agressief gedrag kan optreden.

In principe hebben begrippen als frustratie en emotie/aktivatie betrekking op alle spelers. We veronderstellen dat, naarmate wedstrijden belangrijker zijn of spelers wedstrijden belangrijker vinden, dit de kans op frustratie en/of emotle/aktivatie kan versterken.

Resumerend, in het verloop van het onderzoek zullen we de $\mathrm{f}-\mathrm{a}$ en emotie/aktivatie teorie in onze hypothesen opnemen; zij zullen echter door ons niet meer strikt worden gescheiden.

\section{- De leerteorie}

gestrafte speler:

"de doorgebroken speler was op 2 manleren te stoppen

1we onderuit loggen

20. vasthouden.

Dit latste heb lk gedaan."

Een worm van agressie die met deze teorie in verband wordt gebracht is, zoals we vermeld hebben (par. 2.3.3) de instrumentele agressie.

In de voetbalsport zijn talloze voorbeelden aanwezig die het aannemelijk maken dat instrumentele overtredingen worden toegepast (par. 2.4.2.2). Daarbij wordt valk gesproken van 
een vorm van sportsoclalisatle: overtredingen worden systematies geleerd, verinnerlijkt en dit resulteert in "sociaal verworven normgedrag" (Pilz, 1982).

Het algemene antwoord op onze vraag welke agressieteorieën van toepassing zijn op de sportsituatie kan luiden, dat wij, althans voor ons onderzoek global genomen 2 teoretiese gezichtspunten overnemen.

Dat is allereerst de kombinatie van frustratie-agressie en emotie aktivatie teorie, en ten tweede de leerteorie.

Dit betekent dat we in feite een multi-causale benadering voorstaan; een benadering die o.a. volgens Schilling (1976) en Cauwels (1977a) steeds meer veld wint.

In hoeverre deze teorieën toepasbaar zijn op de door ons gehanteerde onderzoeksvarlabelen wordt in hoofdstuk 4 verder uitgewerkt.

\subsubsection{Relatie status scheldsrechter-teorle}

In dit hoofdstuk hebben wij duidelijk trachten te maken dat de positie van de scheidsrechter in ander onderzoek teoreties weinilg onderbouwd is. Omdat de scheidsrechter in ons onderzoek in feite de bron van het onderzoeksmateriaal vormt, hebben wij getracht zijn positie aan enkele teorieën te relateren. Allereerst hebben we duidelijk gemaakt dat onderscheid dient te worden gemakt tussen feltelijk afwijkend gedrag en afwijkend geregistreerd gedrag.

Ons onderzoeksmateriaal is een duidelijk voorbeeld van deze vorm ook wel aangeduid als "rate producing behavior"; immers de scheidsrechter zelf is een belangrijke "cijferproducerende" instantie.

Vervolgens heeft het verschil in status scheldsrechter als handvat gediend voor de verdere teoretiese invalshoek. Aspekten van de rolteorle en van cognitieve teorieën komen hierbif ter sprake.

Wanneer we onze opmerkingen ten aanzien van de variabele status scheidsrechter samenvatten: niet-officiële scheidsrechters hebben weinig ervaring met het leiden van wedstrijden en een gebrekkige kennis van de spelregels (cognitieve aspekten); zij ervaren daardoor sterk een, overigens aan de scheldsrechterspositie inherent verbonden, rolkonflikt; dit leidt mede door hun binding met de thuisklub tot de veronderstelling dat zij welnig strafzaken aanmelden. 
Bovenstaande opmerkingen gelden niet voor de officiële scheldsrechter. De veronderstelling dat zij, meer dan de niet-officlelen, strafzaken aanmelden wordt nog versterkt door het feit dat zij officiele gezagsdragers van de voetbalbond zijn. Hun funktie is o.a. de orde in het veld te handhaven en officiele gezagsdragers doen veelal datgene wat hen opgedragen is! 
HOOFDSTUK 3.

ONDERZOEK NAAR AGRESSIE IN DE VOETBALSPORT

$\mathrm{Na}$ de teoretiese beschouwingen in het vorige hoofdstuk willen we in hoofdstuk 3 enige onderzoeken vergelijken die de voetbalsport als onderwerp hebben.

Daarbij besteden we allereerst aandacht aan de agressie bij de spelers (par. 3.1) en gaan we vervolgens in op onderzoeken die betrekking hebben op positie en rol van de scheidsrechter (par. 3.2). Paragraaf 3.3 bevat een samenvatting.

\subsection{Agressie van voetballers}

We willen aan de hand van een overzicht van een aantal onderzoeken de in deze onderzoeken gebruikte teoretiese uitgangspunten, metoden en resultaten met elkaar vergelijken (overzicht 3.1).

\subsubsection{Teoretiese uitgangspunten}

In het overzicht zijn die onderzoeken die globaal genomen uitgaan van dezelfde agressieteorieën, bij elkaar geplaatst. Het onderzoek van Volkamer (1971) is hierbij bovenaan het overzicht geplaatst omdat $z i j n$ bijdrage de interesse van de wetenschap ten aanzien van agressieve handelingen in de sport heeft geinitieerd (Albrecht, 1982).

Daarna volgen enige onderzoeken die de resultaten van het onderzoek van Volkamer als uitgangspunt en referentiekader hebben genomen voor eigen onderzoek (Albrecht, 1982).

Vervolgens komt onderzoek aan de orde warbij is uitgegaan van de frustratie-agressie teorie (v.d. Brug, 1981) en leerteoretlese overwegingen (Begerau, 1981).

Een aantal onderzoeken, die hierna in het overzicht genoemd worden, proberen het agressief gedrag van spelers multi-causaal te veklaren, dat wil zeggen men neemt het standpunt in dat niet één oorzaak van invloed is op het agressief gedrag van sporters, maar dat in principe meerdere oorzaken hieraan ten grondslag 1iggen (Ekkers en Hoefnagels, 1972; Gabler, 1976; Lefebvre, 1974; Schmidt, 1978). 
Overzlcht 3.1 .

onderzock nat overtredingen bij voet ba lwedist 1 jden

$\begin{array}{lll}\text { ONDER- } & \text { TEORETIES } & \text { OPERATIONALI- } \\ \text { ZORERR } & \text { UITGANGS- } & \text { SATIE } \\ & \text { PUNT } & \text { AGRESSIE/BRON }\end{array}$

1. Volkamer (1971)

\section{frustratie- agresse teorie// Uber forde- rungsteorie (Herke)}

2. Albrecht toetsing (1982a)

\section{onderzack} Wol kamer(1)

wargehuelng en/of ult het veld, gtrafsch. $/ /$ scheids $T$.

3. Albrecht (1.982b)

toets $1 \mathrm{rg}$ onde rzoek Wolkamer( 1 )

zel fontworpen klassiflkat 1eso systeem// observate

4. vot. Brug (1981)

\section{frustratie-}

5. Begerau leerteorle (1980)

6. Ekkers/ mu1tiHoefnagels ka usaal (1972)

7. Gabler mult(1976) kausaal

8. Lafebvre tult 1(1.974)

9. Schmidt (1978) kausaal

10. Wolf (1962) agressietearte Les.usa 1

door scheids $r$. gekons tateerde overtredingen

zelf ontworpen klassuftkatie systeem

wars chuw 1 ingen wit het veld// scheldsrechter

door scheidsr. gekons tateerdle overtredingen

gele/rode krt. stratschop/l scheldsrechter

Tel fontworpen klags lf that Lesysteem

crimlinologie beledigingen an (vigs straf- overtredingen recht geld. die bllessures atis straf(tak)
OKDERZOEKS-

$>$ KAHS OP ERNHETD

AGRESSTE

1986 wedstrijuen - hogere klasse amateurs (h-DId) - klein doelp.4 setz. 63-67 versctil

- uitspelen

- verliezer

41.52 wedstrijden af hanke $11 \mathrm{jk}$ van profs (W-D1d) operationele selzoem $63-77$ definitie

61 wedstrijden profs + amat.

lagere klase

(W-Did)

(ama teurs)

set $\operatorname{soen} 77-78$

- uitspelen

- middenveld en voar elgen 16 meter-lijn

1 wedstat d profs (Ned) selzaen $80-81$

achterstande ploeg

9 wedstrijden profs (W-Did) selzaen $75-76$

- kletmer doelpuntenverschil

- belang edstir. (rang11jst)

249 strafzaken - lagere klasse profs (Ned) - utispellen selzon $69-70$

13 wedstrijden prof's Whe 1974

- klein doelpuntenverschill

- middenveld en op elgen helft:

240 wadstrlfden - hagere klasse profs (Belgie) - uttspelen le helft - verllezen setzoen $73-74$

41 (jeugd)amat. (W-Did)

3 seiz, $74-77$

be lamgrijkheid verllezen wed$\operatorname{strijd}$

1741 strakzaken - stad

anateurs - lagere klasse velzoen 55-65 
Dverigens wijkt het onderzoek van Schmidt (1978) in zoverre af van de andere onderzoeken dat een specifieke hypothese aan het onderzoek ten grondslag ligt: hoe meer de spelers psychies belast worden, des te vaker komen tijdens de wedstrijd agressieve daden voor.

Tenslotte, vermelden we een onderzoek van Wolf (1962) die alleen die overtredingen bestudeert die vanuit kriminologies gezichtspunt belangrijk zijn; het gat hierbij om overtredingen die ook in het Duitse strafrecht als voldoende voorwarde voor een eventuele strafzaak gelden, namelijk overtredingen die blessures veroorzaken en beledigingen.

\subsubsection{Metoden en populatie}

Naast deze veelvoud aan teoretiese ultgangspunten wordt het onderzoek over agressie in de voetbalsport gekenmerkt door een grote verscheidenheid aan manieren waarop men het gedrag van spelers waarneemt en beoordeelt (Albrecht 1982).

De meeste onderzoeken nemen als bron de door de scheidsrechter waargenomen en beoordeelde overtredingen (de zogenaande operationele definitie van agressie).

Binnen deze operationele definiering zijn er dan nog verschillende toepassingen mogelijk. Men kan uitgaan van alle overtredingen waa rvoor gefloten is (v.d. Brug, 1981; Gabler, 1976), of alleen die overtredingen tot onderwerp van onderzoek maken die officiële strafrapporten met zich mee brengen: boekıngen (officiële waarschuwingen, gele kaarten) en/ of uithetveldzendingen (rode kaarten) (Ekkers en Hoefnagels, 1972; Volkamer, 1971); soms wordt ook de strafschop in het onderzoek meegenomen (Albrecht, 1982; Lefebvre, 1974).

Wolf (1962) engt zijn onderzoeksgebied nog verder in door alleen die overtredingen te behandelen, door de scheidsrechter wargenomen en officleel bestraft, die in het dagelijks leven zouden leiden tot strafrechtelijke vervolging.

Impliciet wordt bij deze onderzoeken verondersteld, dat de scheidsrechterlijke straffen gebaseerd $z i j n$ op "ultingen van agressief gedrag".

Men kan zilch afvragen of de gegevens die men op een dergelifke manier verwerkt, representatief $z i j n$. Bestudeert men uitingen van agressief gedrag of selektieve waarnemingen van scheidsrechters? 
Naast de scheldsrechter als bron kan men ook via zelf ontworpen klassifikatiesystemen van overtredingen het spelersgedrag pogen te verklaren (Albrecht, 1982; Begerau, 1981; Schmidt, 1978). Bij deze onderzoeken treden grote verschillen op in het aantal gekonstateerde overtredingen.

Deze verschillen worden in belangrijke mate bepald door de wijze van abserveren. Bij Albrecht stonden warnemers langs de $11 j n ;$ bij Begerau hadden de beoordelaars de beschikking over een video; een analyse van een wedstrijd duurde gemiddeld 5 à 6 uur!

De gegevens van Schmidt (1978) zijn hiermee moeilijk te vergelijken omdat hij uitgaat van het gedrag van een aantal spelers binnen een team (totaa $\mathrm{N}=41$ ); hij registreert 2971 vormen van agressie bij een aantal werschillende belastingsituaties (variërend van vriendschappelijke wedstrijden tot wedstrijden or een kampioenschap).

Naast de verschillen in teorie en materiaalverzameling zijn er (uiteraard) ook verschillen in de aard en grootte van de populatie. V.d. Brug (1981) geeft een analyse van één Nederlandse eredivisiewedstrijd, terwijl Albrecht (1982) 4152 wedstrijden analyseert.

\subsubsection{Resultaten}

Gezien al deze verschillen in teoretiese gezichtspunten, operationalisering en populatie zal het niet verwonderlijk zijn dat vergelijking van de resultaten moellijk is.

Het onderzoek van Albrecht (1982) toont bijv. aan dat indien als operationalisatie van agressief gedrag, officiële waarschuwingen gehanteerd worden, andere resultaten worden verkregen dan indien men bijwoorbeeld wegzendingen of strafschoppen als operationalisatie zou gebruiken. Bijwoorbeeld de sanktie ult het veld zendingen wordt (nog) meer aan de uftspelende klub gegeven dan de sanktie "officiële waarschuwing".

Een eerste vraag die men zich daarom moet stellen is of alle bovengenoemde verschillen in de diverse onderzoeken ook tot verschillende resultaten leiden. Over het algemeen kan men echter konkluderen dat dit niet het geval is. Meestal worden dezelfde variabelen, werkend in dezelfde richting, genoemd die de kans op agressief gedrag vergroten; een uitzondering hierop vormt de richting van de variabele klassenivo. In het navolgende vatten we de resultaten samen. 
De kans op agressief gedrag wordt vergroot door:

- een hoog klassenivo (Volkamer, 1971; Lefebwre, 1974)

- een laag klassentivo (Albrecht, 1982; Ekkers en Hoefnagels, 1972; Wolf, 1962)

- een klein doelpuntenverschil (Volkamer, 1971; Begerau, 1981; Gabler, 1976)

- het ultspelen (Volkamer, 1971; Albrecht, 1982; Ekkers en Hoefnagels, 1972; Lefebvre, 1974)

verliezen (Volkamer, 1971; v.d. Brug, 1981; Lefebvre, 1974; Schmidt, 1978)

het belang van de wedstrijd (Begerau, 1981; Schmidt, 1978)

- het middenveld of eigen helft (Albrecht, 1982; Gabler, 1976).

De enige variabele die geen eenduidige konkusie oplevert is het klassenivo. Deze verschillen kunnen niet worden toegeschreven aan de aard van de populatie omdat zowel bij amateurs (onderzoeken van Volkamer, 1971 en Wolf, 1962) als bij profs (Ekkers en Hoefnagels, 1972 en Lefebvre, 1974) de verschillen in resultaten blijven bestaan.

Indlen op een hoog klassenivo meer overtredingen voorkomen verklaart men dit vooral door het grotere wedstrijdbelang in deze klasse; terwijl meer overtredingen op een laag klassenivo door Wolf (1962) geinterpreteerd wordt als een kompensatie voor gebrek aan techniek.

Interessant is overigens dat bij een vergelijking tussen profs en amateurs de laatste kategorie gemiddeld meer overtredingen per wedstrijd makt (Albrecht, 1982). Ook bij deze vaststelling blijft het de vraag of dit verschil mede veroorzaakt kan worden door een verschil in scheidsrechtersbeleild.

Over het algemeen gebruiken de onderzoekers ter verklaring van de door hen gevonden resultaten met name de frustratieagressie teorie als verklaringsbron (met name Volkamer, Lefebvre en van der Brug). Een klein doelpuntenverschil, uitspelen, verliezen is om meerdere redenen een bron van frustratie.

Ekkers en Hoefnagels (1972) en Lefebvre (1974) nuanceren in hun onderzoek de resultaten; in beide onderzoeken vraagt men zich af of de scheidsrechter bijwoorbeeld bij het thuis/uitspelen objektief gedrag vertoont en door een of andere oorzaak wellicht de thuisklub bevoordeelt. 
We 111 len daarom in de volgende paragraaf enige aandacht besteden aan onderzoeken die betrekking hebben op de positie en rol van de scheidsrechter.

3.2 .

\section{Onderzoek scheidsrechters}

In de meeste gevallen gaat men ervan uit dat de scheidsrechter objektief is. Heisterkamp (1975a en b, 1977, 1978, 1979, 1980) veronderstelt dat de scheidsrechter onder zware psychologfese druk staat; immers, ledere beslissing in het spel betekent voordeel voor de ene en nadeel voor de andere partij.

Naast deze onderzoeken van Heisterkamp zijn er gegevens bekend over de beoordelings- en beslissingsproblematiek van scheidsrechters (Kranenborg, 1980b; Kuhn, 1977; Philipsen, 1980, 1983; Gootjes en van der Togt, 1982).

Uit met name het onderzoek van Philipsen (1983) blijkt o.a. dat gemiddeld 38 sekonden wordt bijgetrokken op een totale onderbrekingstijd van 15 minuten en 45 sekonden en dat het tijd bijtrekken niet berust op een ondubbelzinnige toepassing van de spelregels (zie ook Kuhn, 1978).

De reeds gememoreerde resultaten van Kranenborg (1980b) kunnen we hier nogmaals samenvatten: onder scheidsrechters bestaat weinig overeenstemming in taakopvatting, beoordelingsproblematiek en opvatting over het sanktiesysteem.

De onderzoeken naar positie en rol van de scheidsrechter leggen geen relatie tussen opvattingen van scheidsrechters en gebeurtenissen op het veld. Onderzoek naar deze relatie is volgens Kranenborg (1980b) gewenst. Het leidt tot bijvoorbeeld de vraag of er bij een scheidsrechter met een informele takkopvatting meer of juist minder overtredingen plaatsvinden dan bij een scheidsrechter met een formele taakopvatting.

Naast deze onderzoeken bestaan er nog publikaties over autoritaire persoonlijkheidskenmerken bij scheidsrechters (Aresu, 1979; Albrecht, 1979a; Pilz en Trebe1s, 1976) en een tuchtrechtelijke verhandeling over de onaantastbaarheid van scheidsrechterlijke beslissingen (Wassing, 1981).

Aresu trof bij voetbalscheidsrechters vergeleken met basketbal1- en tafeltennisscheidsrechters de hoogste tendentie van agressief gedrag aan; P11z en Trebels vergeleken 3 groepen 
scheidsrechters van de laagste amateurklasse tot de "Bundesliga"; personen met "dominanzbetonte" persoonlijkheidskenmerken kwamen vooral voor bij scheidsrechters die wedstrijden leiden in de hogere klassen. Volgens de auteurs is dit resultaat niet zo zeer het gevolg van een scheldsrechter socialisatie mar van een selektieproces namelijk van de door de voetbalbond gepropageerde goede scheidsrechter.

Zij vermelden overigens een interessant eksperiment waarbij een aantal wedstrijden zonder scheidsrechter werd gespeeld. $\mathrm{Na}$ het eksperiment, bleek men, meer als voorheen, de wedstrijd vriendschappelijk, fair, koöperatief en sociaal te vinden.

De resultaten van dit eksperiment versterken onze veronderstelling geuit in par. 2.5 dat in wedstrijden geleid door niet-officiële scheidsrechters spelers een bepaalde verantwoordelijkheid op zich nemen het spel zoveel mogelijk volgens de regels te spelen.

\subsection{Samenvatting}

Wanneer we de resultaten van met name par. 3.1. in herinnering terug brengen is het opvallend dat veel onderzoeken hun materiaal putten uit of via scheidsrechterlijke beslissingen; daardoor is de onderzoeker niet verplicht het begrip agressie te definiëren. Onderzoekers die dit wel doen, dus uitgaan van eigen kriteria (Albrecht, Begerau, Schmidt) konstateren daardoor onderling grote verschilien in het gemiddeld aantal overtredingen per wedstrijd.

Wat ons inziens een manko is van veel onderzoeken naar spelersgedrag, is het niet terugkoppelen van resultaten aan de teoretiese uitgangspunten. Begerau gat uit van een leerteoretles principe maar makt niet duidelijk in hoeverre de samenhang klein doelpuntenverschil - mér overtredingen binnen het leerteoreties konsept geplaatst moet worden.

Veel onderzoeken (o.a. Begerau, Ekkers, Lefebvre en Schmidt) geven aan dat de kans, of gedrag overgat in agressie, mede afhankelijk is van het belang dat men aan het winnen of de wedstrijd hecht.

Ons inziens speelt dit belang een voorname rol bij het verklaren van agressief gedrag in de voetbalsport; vanuit teoreties gezichtspunt gezlen kan het wedstrijdbelang een intermediaire rol spelen tussen veel van onze onderzoeksvariabelen en de agressieteorieën. 
HOOFDSTUK 4.

RELATIE TEORIE - ONDERZOEKSVARIABELE

4.1. Inleiding

Hoofdstuk 2 is afgesloten met de konstatering dat van de door ons behandelde agressieteorleën, in felte twee typen teorle op de sportsituatie toepasbaar worden geacht.

Dat is allereerst de kombinatie van de door ons samengenomen frustratie-agressie en emotfe-aktivatieteorie; deze teorieën zijn samengenomen omdat we van oordeel zijn dat ze in hun werking niet strikt te scheiden $z i j n$. Daarnaast achten we de leerteorie geschikt om agressief gedrag van spelers te verklaren.

Deze teorieên zijn tot dusverre globaal op ons totale onderzoeksmaterlaal toegepast. Wij willen in dit hoofdstuk nagaan in hoeverre onze onafhankelijke variabelen aan de twee typen teorle gerelateerd kunnen worden.

Voordat we op deze relatie nader ingaan willen we onze onafhankelijke variabelen nogmaals opsommen:

- klassenivo

- kompetitiezondag (seizoensverloop)

- verschil in plaats op de ranglijst

- afstand tussen de velden

- uitslag (aantal doelpunten, doelpuntenverschil, winstverlies)

- thuis-uitspelen

- verenigingsgrootte

- urbanisatiegraad

- status scheldsrechter

Par. 4.2 gaat in op de relatie agressieteorie - onafhankelijke varlabele. Daarnaast wordt in par. 4.3 per varlabele, een veronderstelling geformuleerd over de kans op strafzaken en de aard (instrumenteel/reaktief) en richting (speler/scheidsrechter) van overtredingen die tot strafzaken geleid hebben. Deze hypothesen zijn in een overzicht opgenomen (overzlcht 4.1 ).

B1j paragraaf 4.3 dient vooraf een opmerking gemaakt te worden over de door ons gebrulkte begrippen:

Omdat ingegaan wordt op specifleke kenmerken van een strafzaak zullen wij bij onze hypothesen over deze specifieke 
kenmerken spreken over de aard en richting van de overtreding. Daarmee bedoelen we in feite overtredingen die door de scheidsrechter tot officielle strafzaak zijn benoemd, immers allến deze overtredingen zijn in het onderzoek betrokken. Par. 4.4 besteedt aandacht aan de door ons veronderstelde samenhang tussen aard en richting van de overtreding enerzijds en scheidsrechterlijke en tuchtrechtelijke sankties anderzijds.

Par. 4.5 bespreekt een aantal metodiese aspekten die in de loop van het onderzoeksverslag nog uitvoeriger aan de orde zullen komen.

4.2.

Relatie teorie - variabele

Bij de uitwerking van de relatie teorie-variabele werd ons gaandeweg steeds duidelijker dat deze relatie vaak moeilijk te leggen is.

Volkamer (1972b) die een aantal van dezelfde onderzoeksvariabelen hanteert, stelt vast, en relativeert daarmee tevens resultaten en konklusies van eigen onderzoek, (Volkamer, 1971) dat in feite alleen "het verliezen" via redelijke argumenten verbonden kan worden met de $\mathrm{f}-\mathrm{a}$ teorle. $\mathrm{Zijn}$ andere variabelen zijn volgens hem slechts geforceerd aan deze teorie te relateren.

Wanneer we de resultaten van ander onderzoek (par. 3.1.) in de herinnering terugbrengen dan is het opvallend dat veel onderzoekers in hun uitleg van de door hen gevonden resultaten, variabelen relateren aan het belang van de wedstrijd.

Naast Schmidt (1978) wiens onderzoek volledig gebaseerd is op veronderstellingen ten aanzien van het wedstrijdbelang, zijn er andere onderzoekers die "het belang" in bepaalde variabelen vertegenwoordigd zien; Begerau (1981) neemt als indikator voor het wedstrijdbelang de plaats op de ranglifst en Lefebwre (1974) verklaart het groter aantal strafzaken op een hoog klassenivo door het wedstrijdbelang op dit nivo. ans inziens is het wedstrijdbelang een faktor die in de relatie teorie-varlabele een intermedialre rol speelt; dat wil zeggen via het belang kunnen we het verband teorie-variabele leggen.

Daarnaast zijn er nog een aantal intermediaire faktoren die specifiek gelden voor enige van onze onderzoeksvariabelen. In het hiernavolgende willen we deze intermediaire faktoren bespreken: 
1. Het belang van de wedstrijd

scheldsrechter:

"er stand voor belde partijen veel op het spel ze stonden met evenveel gespeelde wedstrijden en evenveel punten bovenaan in hun klasse."

Bif wedstrijden war lets op het spel stat kan dit feite$11 \mathrm{jk}$ gegeven op zich aanleiding geven tot verhoogde aktivatle. Bovendien wordt binnen de kontekst van een belangrijke wedstrijd een onderbreking van doelgericht handelen eerder a1s frustratie ervaren dan in minder belangrijke wedstrijden; dit betekent een verhoogde kans op agressief gedrag.

Het onderscheid in meer of minder belangrijke wedstrijden stelt ons in staat te veronderstellen waarom in sommige wedstrijden wel en in andere geen strafzaken voorkomen.

Voor ons onderzoeksmateriaal kunnen we het wedstrijdbelang onderscheiden in variabelen waarin het belang al voor de wedstrijd vaststaat: klassenilvo, kompetitiezondag, rangplats en afstand en varlabelen die het wedstrijdverloop vertegenwoordigen, watdoor wedstrijden belangrijk kunnen worden: aantal doelpunten, doelpuntenverschil en winstverlies.

\section{Het thuis- of uitspelen}

Met name het uitspelen wordt in diverse onderzoeken als belangrijke bron van frustratie en aktivatie beschouwd (0.a. Volkamer, 1971; Lefebvre, 1974; Gabler, 1976) en kan derha1ve beschouwd worden a1s bevorderend voor het optreden van agressief gedrag.

De frustratie van de uitspelende klub wordt veelal gerelateerd aan zowel het objektleve felt van het "uitnadeel" (bezoekende klubs zouden vaker verllezen) en de hiermee verbonden defensieve taktiek, als aan meer subjektieve faktoren als vijandig publiek, vreende ongeving.

3. De sociale kontekst

Spelers worden beinvloed door de omgeving in hun spelmentaliteit en speelwijze (zle o.a. Prenner, 1972); in ons onderzoek kunnen de verenigingsgrootte en de herkomst van de vereniging (platteland of stad) beschouwd worden als variabelen die deze omgevingsinvloeden vertegenwoordigen. 
Bif de behandeling van de leerteorie (par. 2.3.3) is aangegeven dat agressief gedrag mede geleerd kan worden door direkte ervaring. Een van de bronnen van direkte ervaring is de subkultuur.

Ons inziens kunnen de grootte en herkomst van de vereniging als subkulturele eenheden beschouwd worden en hebben ten aanzien van het voorkomen van agressief gedrag dus een leerteoretiese achtergrond.

Overigens is het vanuit teoreties gezichtspunt van belang op te merken dat deze faktor een wisselwerking impliceert tussen personen in de spelsituatie en hun binding met "de buitensituatie". Met andere woorden een absolute scheiding tussen spel/sport en het dagelijks leven is niet te maken (zie aok Stokvis, 1979).

De relatie tussen deze variabelen en agressief gedrag zullen wij bij de specifieke behandeling van deze variabelen nader uitwerken.

W1j zijn er ons overigens, bij het hanteren van deze "sociale kontekst"-variabelen, wel van bewust dat zij verder van het wedstrijdgebeuren afstaan, dan bijvoorbeeld de belangvarlabelen; door deze afstand kunnen allerlei andere faktoren een rol spelen bij het voorkomen van agressief gedrag. Bijvoorbeeld, het onderscheid platteland-stad, is globaal; er zijn mogelijke verschillen tussen het gedrag van spelers afkomstig uit reeds lang bestaande verenigingen in een hechte stadswijk of -buurt en spelersgedragingen van nieuwe verenigingen gelegen in nieuwbouwwijken (Frankenberg, 1979; Mizruchi, 1985). Aan deze veronderstelling ligt ten grondslag een mogelijk verschil in kultuur en dus verschil in normering van agressief gedrag.

Resumerend, via deze 3 faktoren kunnen we agressleteorie en variabele verbinden en door deze faktoren kunnen we per variabele veronderstellingen doen over de kans op en de aard en richting van strafzaken.

Voor ons onderzoek is het uiterst belangrijk te weten hoe groot de kans op een strafzaak is.

4. De arbitrage speelt hierin een besilssende rol.

Het is, zoals vermeld, (par.2.5) mogelijk 2 typen scheldsrechters te onderscheiden, de officiële vs. de nlet-officiële scheidsrechter. 
De varlabele scheidsrechter staat, wat teoreties ultgangspunt betreft, los van de zojuist behandelde drie intermediaire faktoren. Niet de agressieteorleën maar aspekten van het teoreties begrlp rol en van de cognitieve teorleën, zijn, zoals in par. 2.5 vermeld, op de status van de scheldsrechter van toepassing.

Resumerend :

Via het wedstrifdbelang, het thuis-uitspelen, de sociale kontekst en de variabele status scheidsrechter zifn voorspe111ngen mogelljk over de kans op strafzaken.

Overigens willen we benadrukken dat de hierboven genoemde vier faktoren ook onderling kunnen samenhangen. Scheldsrechters zouden bijvoorbeeld in belangrijke wedstrijden de regels anders kunnen toepassen; in het midden latend of dit meer of minder stringent optreden betekent (Schiling, 1976).

Bij onze veronderstellingen per variabele gaan wij er echter vanuit dat ondanks eventuele samenhangen de door ons verwachte richting van het verband blifft bestaan (met andere woorden de ceteris paribus clausule).

Naast voorspellingen over de kans op of strafzaken die een antwoord kunnen geven op onze eerste probleemstelling willen we tevens per onafhankelijke variabele hypothesen formuleren over de aard en richting van de overtredingen die tot een strafzaak hebben geleid. Met name de aard van de overtreding (instrumenteel of reaktief) staat hierbij centraal.

Hiervoor is een teoretlese reden aan te geven:

In hoofdstuk 2 is vermeld dat de agressleteorieën niet strikt te schelden zifn; frustratie en/of emotie-aktivatie kan via leerprocessen bijvoorbeeld omgezet worden in niet agressief gedrag.

Indien we deze teorieën toch schelden is dit met name om duldelifk te maken dat gedragingen gerelateerd aan de $f-a$ en emotie-aktivatie teorie in de spelsituatie in veel onderzoeken beschouwd worden als doel op zich en geen funktie in het spel zouden hebben; gedragingen vanult leerteoreties perspektlef zouden vooral -maar niet ultsluitend- instrumenteel agressief $z i f n$. Daarbif wordt door een aantal onderzoekers verband gelegd tussen het belang van de wedstrijd ("het winnen") en thet voorkomen van instrumentele agressie (Ekkers, 1975; Schmidt, 1978; Pilz, 1980a). 
Met andere woorden variabelen die met name dit winstbelang vertegenwoordigen zouden redelijke voorspellers kunnen $z i j n$ ten aanzien van het voorkomen van instrumentele agressie. Daarnaast beschikken we over een aantal variabelen die naast het winstbelang ook het emotionele belang vertegenwoordigen. We denken aan onze variabelen afstand tussen de velden ( $r i-$ valiteit) en winst/verlies, met name het verlies. Dit emotionele belang zou dan samen kunnen hangen met reaktieve agressie. Bij de veronderstelling per variabele komen we hierop terug.

Bij de behandeling van de variabelen zullen we tevens nagaan of we de richting van de overtreding kunnen voorspellen; dat wil zeggen wordt de overtreding begaan ten opzichte van speler of scheldsrechter.

Dat de richting van de overtreding is opgenomen houdt overigens vooral verband met de variabele scheidsrechter. Omdat we in ons materiaal onderscheld kunnen maken in officiele en niet officiële scheidsrechters is het interessant na te gaan of de status van de scheldsrechter met de richting van de straf samenhangt.

Daarnaast kunnen we ons, door de richting van de overtreding op te nemen, afvragen in hoeverre de ernst van de sanktie van de tuchtkommissie beinvloed wordt door de richting ervan.

$4 \cdot 3$.

Hypothesen, per onafhankeli jke variabele, over de kans op strafzaken en over aard en richting ervan.

\subsubsection{Klassenivo}

In ons onderzoeksmateriaal worden wedstrijden belangrijker naarmate het klassenivo hoger wordt (immers, in de hoogste klasse is promotie mogeli jk naar het KNVB-amateurvoetba 1 ). Hoewel onderzoek ten aanzien van het klassenlvo geen eenduldige konklusie oplevert, sommigen treffen op een hoog klassenivo meer strafzaken aan, anderen konstateren meer strafzaken op een laag nivo (zie par. 3.1.3), veronderste1len we, met name door de struktuur van de afdeling, een verband tussen eem hoog $\mathrm{klassenivo} \mathrm{en} \mathrm{het} \mathrm{voorkomen} \mathrm{van} \mathrm{straf-}$ zaken. Overigens is het wedstrijdbelang ook vanuit de individuele spelerpositie uit te leggen. Schmidt (1977) stelt vast dat spel-sterkere spelers ("de sterren") agressiever 
regaeetden op bepalde spelsituaties. Met andere woorden naarmate een persoon het spel beter beheerst, wordt het wedstrifdbelang voor hem ook groter. Een analoog voorbeeld ult de sportsituatie 1 s een konstatering van P11z (1979) dat voetballers bij wie "resultat en wedstrijdbelang" dominant $z 1 j n$ in hun handelingsrepertoire minder bereid $z i j n$ overtredingen te tolereren. Naast het algemeen belang van de wedstrljd speelt mee dat de spelers geleerd hebben welke overtredingen wel of niet effektief zijn (sportsocialisatie) (zle ook P11z, 1981).

Dit leerproces geeft tevens anlelding te veronderstellen dat overtredingen vooral 1 instrumenteel zullen zijn (immers het behalen van winst is uiterst belangrijk). Uit onderzoek blifkt dat deze overtredingen niet alleen ten opzlchte van de spelers plaatsvinden (Schmldt, 1979), mar ook ten opzlchte van de scheldsrechter (Gootjes en van der Togt, 1982); in het laatste geval probeert men de beslissingen van de scheidsrechter te sturen (de "professloneel" uitgelokte strafschop).

Met andere woorden de kans op overtredingen is groter op een hoog klassenivo; we verwachten op dit nlvo vooral instrumentele overtredingen ten opzichte van speler én scheidsrechter.

\subsubsection{Kompetitiezondag (selzoensverloop)}

In het begin van het seizoen heeft ledere wedstrijd nog een groot belang; naarmate het selzoen vordert zijn er veel elftallen die geen kans meer maken op promotie of degradatie, dat wil zeggen over het totale wedstrijdenbestand genomen, worden de wedstrijdbelangen minder.

In de variabele kompetitiezondag willen we tot uiting brengen dat spelers gedurende het selzoen ervaren, via elgen gedrag of van dat anderen, welke overtredingen effektief zijn. Dat w11 zeggen leveren de overtredlngen winst op en welke scheldsrechterlijke sankties $21 \mathrm{jn}$ te verwachten.

We veronderstellen daarom vooral aan het einde van het seizoen 1 nstrumentele overtredingen, warbij we geen argumenten hebben te veronderstellen dat deze overtredingen specifiek ten opzlchte van speler of scheldsrechter gericht $z i j n$.

De kans op overtredingen is derhalve groter aan het begin van het selzoen, terwijl we an het einde van het seizoen meer instrumentele overtredingen verwachten. 


\subsubsection{Verschil in plaats op de ranglifst}

Een wedstrijd met klein rangverschil impliceert een gelijkwaardige kwaliteit van elftallen en gelijkgerichte belangen, met andere woorden een grotere kans op overtredingen (Volkamer, 1971).

Door deze gelijkwaardigheid veronderstellen we dat de elftallen trachten via instrumentele overtredingen de winst te bereiken.

Met andere woorden de kans op instrumentele overtredingen is groter bij een klein verschil in plaats op de ranglijst.

\subsubsection{Afstand tussen de velden}

Een kleine afstand tussen de velden kan betekenen een grotere kans op rivaliteit, spanning tussen beide elftallen en daardoor een verhoogd wedstrijdbelang (Wolf, 1962; Miermans, 1955).

Ondat deze rivaliteit vooral berust op emotie, verwachten we dat de overtredingen een meer reaktief karakter zullen dragen; daarbif hebben we geen redenen aan te nemen dat deze overtredingen meer ten opzlichte van speler of scheldsrechter zullen plaatsvinden.

Dus, de kans op reaktieve overtredingen is groter bij een kleine afstand.

De hierna volgende variabelen aantal doelpunten, doelpuntenverschil en winst-verlies vertegenwoordigen ons inziens het wedstri jdverloop.

4.3.5. Aantal doelpunten, doelpuntenversch11 en winst-verlies

Deze variabelen hebben we bij de behandeling samengenomen omdat $z i j$ onderling samenhangen.

We veronderstellen dat een klein aantal doelpunten c.q. klein doelpuntenverschil het direkte wedstrijdbelang aangeeft voor belde partijen.

Zowe1 Sprenger (1974), Gabler (1976) als Lefebvre (1980) veronderstellen bij een gering aantal doelpunten c.q. klein doelpuntenverschil vooral instrumentele overtredingen. Sprenger benadrukt daarbij nog dat in deze situaties instrumentele agressie een verwachte en vaak geeiste handeling is om tot resultaat te komen. Bij een groot doelpuntenverschil 
verwachten we vooral reaktieve overtredingen van de verliezers.

Over het algemeen veronderstellen we dat verlies (immers blokkering van het doel, winst) een reële bron van frustratle betekent (zle ook Volkamer, 1972b; Lefebvre, 1974, 1980; Schmidt, 1978, 1979 en v.d. Brug, 1981). Overigens leidt het "achterstaan" tot verhoogde inspanning om gellijk te komen (Ekkers, 1975); dit betekent dat men met alle middelen, dus ook overtredingen zal trachten het verlles ongedaan te maken. Geen van deze onderzoeken geven overigens uitslultsel over de richting van de overtreding.

Resumerend de kans op overtredingen is groter bij een gering aantal doelpunten, een klein doelpuntenverschil en bij ver11es.

Bij een gering aantal doelpunten en een klein doelpuntenverschil verwachten we instrumentele overtredingen; bij een groot doelpuntenverschil en verlles verwachten we vooral reaktieve overtredingen van de verliezers.

\subsubsection{Het thuls- of uitspelen}

Diverse onderzoeken (o.a. Volkamer, 1971; Lefebvre, 1974) maken duidelijk dat on diverse redenen, objektleve thuisvoordeel, vijandig publiek, andere entourage, de uitklub, ook al vбór de wedstrijd, een gevoel van frustratie kan ervaren. Deze frustratie zou de kans op het maken van overtredingen doen toenemen. Tevens zou het thuisvoordeel (thuisklubs winnen vaker) betekenen dat uitspelende klubs een meer defensieve taktiek toepassen. Uit onderzoek (Gabler, 1976) is gebleken dat verdedigers meer overtredingen maken.

Wat de aard van de overtreding betreft, konkluderen Ekkers en Hoefnagels (1972) dat met name uitspelers meer verbale agressle (tegen de scheldsrechter) zullen vertonen. Zij konkluderen daarbif dat wanneer direkte agressie tegen frustrator of substituut te veel kans op bestraffing geeft, men ultgande van de $f-a$ teorle, zijn toevlucht zal nemen tot meer indirekte vormen van agressie. Met andere woorden de kans op overtredingen is groter bif spelers van de uitklub; en (de konstatering van Ekkers en Hoefnagels overnemend) de uitspelers zullen hun mogelijke frustratie uiten in reaktieve overtredingen ten opzichte van de scheidsrechter. 
De twee volgende te behandelen variabelen, verenigingsgrootte en urbanisatiegraad veronderstellen een invloed van de omgeving (vereniging of platteland/stad) op het spelersgedrag en zijn vooral vanuit leerteoreties gezichtspunt belangrijk bij het verklaren van agressief gedrag.

\subsubsection{Verenigingsgrootte}

Onze veronderstellingen baseren zich op twee gezichtspunten:

1. Lammers (1964) stelt vast dat de negatieve Invloed van organisatiegrootte op de daadwerkelijke uiterlijke samenhang een verband is dat slechts onder bepaalde voorwaarden optreedt. In groelende verenigingen kan een zekere formalisering optreden en/of kan de samenhang tussen de onderdelen zwakker doen worden. Dit zou kunnen betekenen dat een grotere organisatie meer kans biedt aan doelgroeperfingen of segmentering (zie ook Lenk, 1972).

We veronderstellen dat grote sportverenigingen door het grote aantal elftallen, de leden meer de mogelijkheld biedt te klezen voor het spelen op een laag klassenlvo. Deze spelers zouden dan minder waarde hechten aan prestatie c.q. Winst. Dit betekent dat grotere verenigingen minder bij strafzaken betrokken zijn.

2. In kleine verenigingen is het belang van elke wedstrijd groot; dit betekent een nadruk bij spelers, trafner, bestuur en publiek op winst. Tevens betekent dit, dat men als kleine vereniging zorg moet dragen voor de naam van de klub; reaktieve overtredingen (die over het algemeen als meer ernstig worden beschouwd) kan men $z$ ich niet veroorloven.

Met andere woorden de subkultuur is mede verklarend voor het al dan niet voorkomen van agressief gedrag; in deze betekenis is de leerteorle op deze variabele van toepassing.

Resumerend kleine verenigingen zijn meer bil strafzaken betrokken; daarbij zullen de spelers vooral instrumentele overtredingen toepassen.

\subsubsection{Urbanisatiegraad}

We veronderstellen dat "stedelingen" in het algemeen een meer kosmopolitiese oriëntatie hebben dan de meer lokale oriëntatie van de platteland-bewoners (Philipsen, 1969). 
Deze kosmopolftlese orlëntatie uit zich volgens ons in een rulmere interpretatie van wat op het veld wel en niet mag; tevens kan deze oriëntatie zorgen voor een milndere gedragsaanvaarding - de gerlngere sociale kontrole van de stad kan hierbij een rol spelen.

Dit betekent dat wij bij stedelijke verenigingen een grotere kans op overtredingen verwachten, zowel instrumenteel als reaktlef.

\subsubsection{Status scheidsrechter}

In par. 2.5. hebben we de variabele status scheidsrechter gerelateerd aan aspekten van het sociologiese begrip rol en aan aspekten van cognitleve teorieën. Wanneer we een verge1ijking maken tussen officiële en niet-officiële scheidsrechters kunnen we naar aanleiding van deze aspekten tot de volgende konstateringen komen: De officiële scheidsrechter ervaart het rolkonflikt waarin hij zlch bevindt als minder belastend:

- door betere kennis van de spelregels (scheidsrechterskursus) en ervaring met het leiden van wedstrijden, resulterend in het beter waarnemen en beoordelen van spelsituaties;

- doordat ze de wedstrijd beter aanvoelen door hun grotere ervaring (de ongeschreven normen);

- omdat ze meer bij de wedstrijd betrokken zijn (karriererapporteurs);

- omdat ze meer objektief zijn (geen lid van een der spelende verenigingen).

Dit minder ervaren van een rolkonflikt zorgt er ons inziens voor dat officiëlen meer strafzaken zullen aanmelden dan de niet-offlciellen.

Deze hypothese wordt nog versterkt door het gedrag van de spelers. Zif zullen naar onze mening in de wedstrijd de scheldsrechter als offl̈clële gezagsdrager zien en hem uittesten in het begaan van overtredingen. Dit in tegenstelling tot spelers die wedstrijden spelen geleid door niet-officiëlen; zij zullen meer verantwoordelijkheid in hun positie ervaren om de wedstrijd sportief te laten verlopen.

Dit betekent dat officiëlen meer instrumentele overtredingen sanktioneren, ervan uitgaande dat deze moellijker te konstateren en te interpreteren zijn en derhalve ervaring in het waarnemen en doorzien van spelsituaties vereist. 
Reaktieve overtredingen, overtredingen die op zich niets met het spel als zodanig te maken hebben (slaan, natrappen) zijn duide11jker waarneembaar, en makkelifker interpreteerbaar er is meestal weinig twiffel over de opzet van de overtreding. Met andere woorden vooral de niet officielen zullen reaktieve overtredingen bestraffen.

Bovenstaande veronderstellingen uit par. 4.3. zijn samengevat in het hierna volgende overzicht.

Een tteken in overzicht 4.1 . geeft aan dat onze veronderstelling over de kans op strafzaken, en aard en richting van de overtreding die tot strafzaak wordt, voor de desbetreffende variabele in dezelfde richting wijst; een -teken duidt erop dat de werking van de variabele wat betreft de aard en richting van overtreding tegengesteld is aan de werking bij de kans op strafzaken. 
Overzlcht 4.1 .

Veronderste111ngen, per onderzoeksvariabele over de kans op strafzaken en de aard en richting van de overtreding.

$>$ kans op instrumenteel reaktief strafzaken speler schelds- speler scheidsrechter rechter

WEDSTRI JDBELANG

- klassenivo hoog

- seizoen begin

- rangversch11 klein

- afstand klein$$
+
$$$$
+
$$

WEDSTRIJDVERLOOP

- aant. doelp. klein

- doelp.verschil gering

- winst-verlies verlies

$+$

$+$

\section{THUIS-UITSPELEN}

- uitspelen

SOCIALE KONTEKST

- veren.grootte klein

- urbanis.graad stad

ARB ITRAGE

- off. scheidsr.

(1) +teken: hypothese ten aanzien van aard-richting overtreding gelijk aan hypothese kans op strafzaken.

(2) - teken: hypothese ten aanzien van aard-richting overtreding tegengesteld aan hypothese kans op strafzaken. 
In hoofdstuk 1 is een aantal vraagstellingen geformuleerd dat betrekking heeft op de gevolgen van bepaalde overtredingen voor de spelers. Welke sankties kunnen zij van scheidsrechter en tuchtkommissie verwachten? Vervolgens is in hoofdstuk 2 (par. 2.4.2.2.) vastgesteld dat een van de overwegingen van spelers om overtredingen te begaan, is, het afwegen van het voordeel van de overtredingen tegen het nadeel van de straf. Is dit voordeel volgens de speler inderdaad aanwezig dan kan met name instrumentele agressle verwacht worden.

In dit licht bezien lijkt het ons derhalve nuttig en zinvol aandacht te besteden aan sankties in de voetbalsport. De relevantie van het bespreken van sankties kan tevens gerelateerd worden aan de aard van ons onderzoeksmaterfaa1. Omdat we onderscheld kunnen maken in officlële en nlet-officlële scheidsrechters kunnen we nagaan in hoeverre er verschil bestaat in hun sanktiebeleid en in hoeverre de tuchtkommissie rekening houdt met de status van de scheidsrechter.

Overigens willen wij nog wijzen op een verschll in teoretiese onderbouw ten aanzien van veronderstellingen over scheidsrechterlijke en tuchtrechtelijke sankties.

De aan de status van de scheidsrechter gerelateerde rol- en cognitieve teorieèn werken door in onze veronderstellingen over scheidsrechterlijke sankties. Mér dan voor de scheldsrechters geldt voor de tuchtkommissies dat zij meer een uitvoerende taak hebben; immers de kommissies nemen de reden en motivering van de scheidsrechterlijke sanktie op in hun eigen beslissingen; ledere overtreding "staat" voor een bepaalde straf, terwijl de straf mede afhankelijk is van de aanwezige strafkaart van de betrokken speler.

Veronderstellingen met betrekking tot tuchtrechtelijke sanktles hebben daarom geen speciflek teoreties fundament. Dit betekent dat resultaten in dit kader minder een toetsend karakter hebben maar, meer als bif de scheidsrechterlijke sanktie, gezien moeten worden als antwoorden op door ons zinvol geachte vragen.

Wat zijn nu de veronderstellingen ten aanzien van de sanktles van scheldsrechter en tuchtkommissie.

- Veronderstellingen zijn gebaseerd op de over door ons geformuleerde ve sankties verwachting 
(par. 4.3.9) dat officiellen meer instrumentele- en niet-officlëlen meer reaktieve overtredingen zullen bestraffen.

$B 1 \mathrm{~J}$ het onderscheld in instrumentele-reaktieve agressie gaan we er van uft dat scheidsrechters de laatste vorm van agressile als ernstiger beschouwen; ernstiger omdat de overtreding niet funktioneel is in het spel en veelal een fysiek karakter draagt; overigens realiseren we ons dat reaktieve agressle niet synoniem is aan fysleke agressie.

D1t alles betekent dat officielien meer lichte sankties (waarschuwingen) zullen toepassen. Mede omdat wedstrijdleiders zolang mogelijk beslissingen uitstellen, zullen ze dan pas tot een offlciële straf overgaan, als de overtreding duidelijk warneembaar is en dermate ernstig dat een beslissing boven elke kritiek zal staan. Dit laatste zou dan een grotere kans op uft het veldzendingen betekener.

- Veronderstellingen over sankties van de tuchtkommissies zijn, zoals zojulst beschreven van een andere orde. Het gaat hier fmmers om sankties die vooral bepaald zullen worden door de schelldsrechterlijke sanktie én de richtlijnen die voor bepaalde overtredingen gelden.

Daarom nemen we aan dat, indien we veronderstellen dat scheidsrechters reaktieve agressie met een zware sanktie bestraffen, tuchtkommissies in leder geval deze vorm van agressie vooral door onvoorwaardelijke straffen zullen laten volgen.

We veronderstellen vervolgens dat overtredingen tegen de scheidsrechter, door de kommissies, in vergelijking met overtredingen ten opzichte van de spelers zwaarder zullen worden bestraft. (De aard van de overtreding is bij deze veronderstelling "konstant" gehouden.)

Impliciet $11 \mathrm{gt}$ aan deze veronderstelling ten grondslag dat de tuchtkommissie als rechtsprekend orgaan van de voetba 1 bond, overtredingen ten opzichte van een gezagsdrager als ernstiger beschouwt.

Interessant is het bij deze veronderstellingen na te gaan in hoeverre de status van de scheidsrechter van invloed is op de sanktie van de tuchtkommissie. Omdat tuchtkommissies kennts hebben van de positie en rol van niet-officiële scheidsrechters veronderstellen we dat, meer dan blj officiëlen, bif beslissingen van niet-offlciëlen zif "korrigerend" zullen optreden, dat w1l zeggen minder zware sankties zullen toepassen. 


\section{Resumerend:}

We verwachten ten aanzien van scheidsrechterlijke sankties dat:

officiele scheidsrechters meer waarschuwingen als sanktiemidde1 zullen toepassen;

niet-officiële scheidsrechters verhoudingsgewijs meer spelers uit het veld zullen sturen.

Ten aanzien van sankties tuchtkommissie verwachten we dat:

- reaktieve overtredingen (in navolging van het veronderstelde scheldsrechtersbeleid) zwaarder zullen worden bestraft;

- overtredingen ten opzichte van scheidsrechters zwaarder worden bestraft;

- beslissingen van niet-officiëlen gevolgd worden door relatief lichtere sankties.

\subsection{Metodiese opmerkingen}

De navolgende hoofdstukken bevatten zowel beschrijvende als verklarende elementen.

Met name in hoofdstuk 5 zal de beschrijving van de onafhankelijke variabelen geschleden in de kontekst van de mate warin een variabele samenhang vertoont met het al dan niet voorkomen van strafzaken.

Deze samenhang zullen we uitdrukken in de associatiemaat tau, omdat onze onafhankelijke variabelen een ordinaal nivo bezitten. Bij deze associatiemat wordt (in tegenstelling tot bijvoorbeeld bij de Chi-kwadrat) de grootte en richting van het verband aangegeven en loopt van ti tot -1 . Aan deze kenmerken zullen wij meer waarde hechten dan aan het al dan niet signifikant zijn van de samenhang. De grootte van onze onderzoekspopulatie $(\mathrm{N}=12.390)$ zal er immers voor zorgen dat signifikantie nogal vaak op zal treden. Uiteraard is het dan nog nodig een signifikatiegrens aan te geven.

We gaan daarbij uit van een $5 \%$ signifikantiedrempe1. Deze metodiese beslissing betekent dat de samenhang niet signifikant is indien er meer dan $5 \%$ kans bestaat dat de uitkomst aan het toeval kan worden toegeschreven.

Bij de toetsing van onze probleemstellingen wordt de wedstrijd als analyse-eenheid beschouwd. Bij de eerste pro- 
bleemstelling "welke faktoren doen wedstrijden met en zonder atrafzaken van elkaar verschillen", is deze keuze vanzelfsprekend.

Bij toetsing van veronderstellingen ten aanzien van aard en richting van de strafzaken zou de strafzaak ook als analyseeenheld gehanteerd kunnen worden. Omdat, de aard en richting van de overtreding zich op een verantwoorde wijze in een aantal wedstrijdtypen laat onderbrengen zal ook bijtoetsing de wedstrijd analyse-eenheid $z i j n$. Echter, indien we nader ingaan op de sankties van scheldsrechter en tuchtkommissie, zal de strafzaak als analyse-eenheid gebrulkt worden. Immers een sanktie heeft betrekking op een individuele situatie en Is derhalve niet als wedstrijdkenmerk te beschouwen.

Een laatste metodies aspekt betreft onze beslissing bij de verdere verwerking van de gegevens veelvuldig gebruik te maken van een steekproef ult ons totale bestand. In 1 op de 7 kompetitiewedstrijden komen een of meer strafzaken voor ( $N$ resp. 1750 en 10.641). Daarom hebben wij o.a. bij toetsing van de hypothese warom in sommige wedstrijden wel en in andere geen strafzaken voorkomen een steekproef genomen zodanig groot dat het aantal wedstrijden zonder strafzaak gelijk is aan het aantal wedstrijden met strafzaak.

De reden van het nemen van een steekproef is dat de scheve verdeling tussen wedstrijden met en zonder strafzaken daardoor verdwijnt. 
HOOFDSTUK 5 .

EIGENSCHAPPEN VAN WEDSTRIJDEN MET EN ZONDER STRAFZAKEN

5.1 .

Inleiding

In dit hoofdstuk willen we onze eerste probleemstelling toetsen. Deze 1uldt: kunnen we bepalde faktoren aanwijzen die het verschil verklaren tussen wedstrijden met en zonder strafzaken.

Het hoofdstuk bevat twee gedeelten; het eerste - par. 5.2. $t / m$ par. 5.12 heeft een meer beschrifvend karakter; in het tweede gedeelte wordt de probleemstelling getoetst.

We beschrijven allereerst de onafhankelijke varlabelen die we later in de verklarende analyses zullen gebruiken.

Gezien de aard van de probleemstelling: het verklaren van het onderscheid tussen wedstrijden met en zonder strafzaken, kan een tweetal variabelen uit hoofdstuk 4 niet meegenomen worden; de sanktie van de tuchtkommissle die uiteraard alleen betrekking heeft op wedstrijden met strafzaken en de variabele thuls-uitspelen die bij een dergelijke probleemstelling moellijk te toetsen valt. Overigens komen we op het thuis-uitspelen nog in hoofdstuk 8 uitgebreld terug.

Bij ledere variabele geven we de operationalisatie aan en de feitelijke (bivariate) samenhang met het voorkomen van strafzaken, uitgedrukt in de associatiemat tau. Bij de weergave van deze samenhang is uitgegaan van de totale onderzoekspopulatie ( $N=12.391)$, mede ingegeven door het informatieve karakter ervan.

Zoals in par. 4.5 is besproken, zal door de grootte van onze onderzoekspopulatie bijna altijd signifikantie optreden. De weergave van de associatiemat is vooral bedoeld om de grootte en richting van de verbanden aan te geven, zodat de variabelen in dit opzicht met elkaar kunnen worden vergeleken.

Par. 5.10 geeft een beschrijving van de belangrijkste onder11nge samenhangen van de onafhankelijke variabelen.

Daarna wordt in par. 5.11 kort ingegaan op een enquete onder scheldsrechters die we in de loop van het onderzoek gehouden hebben. Deze enquete, die vooral bedoeld was na te gaan of en in hoeverre er in de afdeling Limburg sprake is van rivaliteit tussen bepaalde verenigingen, zou nuttige achter- 
grondinformatle kunnen verschaffen over met name de variabelen afstand, verenigingsgrootte en urbanisatiegraad.

De beschrifving van de varlabelen wordt vervolgd met een beschryjuing van de kompetitie in de afdeling Limburg; omdat de kompetitie regional geschiedt is het van belang stil te staan bil de diverse regio's (par. 5.12).

Deze beschrijving geeft naast de belangrijkste kenmerken van de vijf regio's, per reglo informatie over de samenhang van ledere onathankelijke varlabele met wedstrijden met en zonder strafzaken. Afhankelijk van het feit of de regio's onderling grote verschillen laten zien kan de beslissing genomen worden of de nadien te verrichten analyses al dan niet reglonal moeten geschieden.

B1j de weergave van de samenhang van onafhankelijke variabelen en wedstrifden met en zonder strafzaken is overigens gebruik gemaakt van een steekproef uit het totaal aantal wedstr1jd zonder strafzalk in de desbetreffende regio's. In paragraaf 5.12 zullen wij op de verantwoording van de steekproeftrekking nader ingaan.

In het tweede gedeelte van dit hoofdstuk, par. 5.13, wordt de probleemstelling getoetst. Gezien de aard van de probleemstelling, nagaan op welke faktoren wedstrijden met en zonder strafzaken het sterkst verschillen is voor toetsing de diskriminantanalyse bij uitstek geschikt. Daarnaast wordt ter toetsing van de probleemstelling tevens gebruik gemaakt van de kontrastgroepenanalyse; nadere uitleg van deze techniek vindt in par. 5.13 .2 plaats.

Het hoofdstuk wordt besloten met een samenvatting van de resultaten: par. 5.14 .

We beginnen nu met een beschrijuing van de onafhankelijke varlabelen, die later in de multi-variate analyses zullen worden gebruikt. De samenhang van enkele variabelen is in een aantal graflese tabellen weergegeven. In deze weergave is alleen het percentage wedstrijden met strafzaken vermeld. De aantallen die bij deze percentages behoren staan in de biljlagen.

Alleen indien de samenhang niet signifikant is $(p<.05)$ wordt dit in de desbetreffende tabel aangegeven.

5.2 . Klassentvo

De kompetitie speelt zich af op vier verschillende klassenivos; binnen deze nivo's bestaan specifieke klassen ( $N=$ 101) (resp. $n=12,24,24$ en 41 ). 
In principe spelen binnen een specifieke klasse er noott meer dan 12 verenigingen; wel komt het voor dat op de lagere klassenivos 3 en 4 minder verenigingen binnen een klasse spelen.

Aangenomen mag worden dat het verschil in kwaliteit tussen elftallen kleiner wordt, naarmate het klassenivo hoger wordt (men speelt 1mmers in de eerste en tweede klasse vooral op grond van verworven kwaliteiten).

Promotie in de eerste klasse levert overgang op naar de grote bond het $\mathrm{zgn}$. KNVB-amateurvoetbal en is dus erg belangr $\mathbb{1} j \mathrm{k}$.

Aan de andere kant is degradatie in de vierde klasse niet mogelijk; "lager" voetballen kan men niet!

Onze veronderstelling uit hoofdstuk 4 dat op een hoog klassenivo meer strafzaken zullen voorkomen wordt door bovenstaande beschrijwing nog versterkt.

Tabe1 5.1. (zie ook bijlage tabel 5.1A)

\% wedstrijden met strafzaken naar klassenivo $(\mathrm{N}=12.391)$.

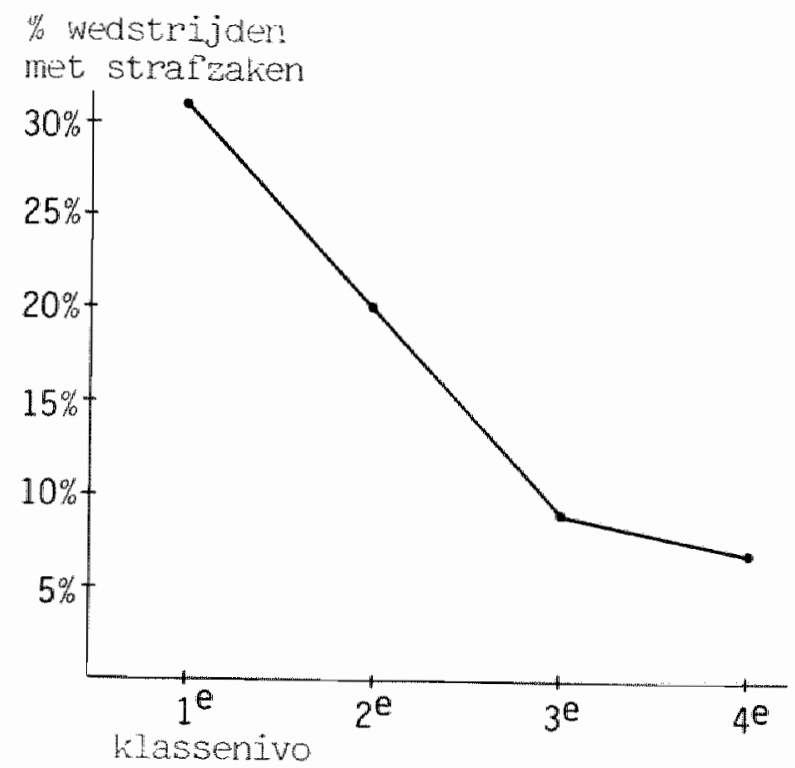


De konklusie naar aanlelding van tabel 5.1 kan eenduidig zijn: hoe hoger het klassenivo des te meer wedstrijden met strafzaken.

B11jkt op het eerste klassenivo globaal 1 op de 3 wedstrijden een strafzaak te bevatten, op het $4 \mathrm{e}$ klassenivo $1 \mathrm{~s}$ deze verhouding $1: 14$.

\subsection{Selzoensverloop (kompetitiezondag)}

De kompetitie bestaat in princlpe (gegeven het maximaal aantal van 12 elftallen per klasse) uit 22 wedstrijdzondagen. Gezlen de onvermijdelifkheid van afgelastingen, omzettingen e.d. werden in de kompetitie $80-81$, 46 wedstrijddagen benut; tussen half december en eind januari lag de kompetitie een vijftal weken sti1. Vooral op het einde van de kompetitie, apri1/mei, vindt een ware 1 nhaalrace in wedstrijden plaats, waarbij in sommige weken 5 van de 7 weekdagen benut (moeten) worden.

Gedurende een 15-tal zondagen wordt een min of meer volledig programma afgewerkt ( +570 wedstrijden).

Onze veronderstelling is dat vooral aan het begin van het selzoen de kans op overtredingen $c \cdot q$. strafzaken groter is.

Tabe1 5.2. (zie ook bijlage tabel 5.2A)

\% wedstrijden met strafzaken naar seizoensverloop $(\mathrm{N}=12.391)$.

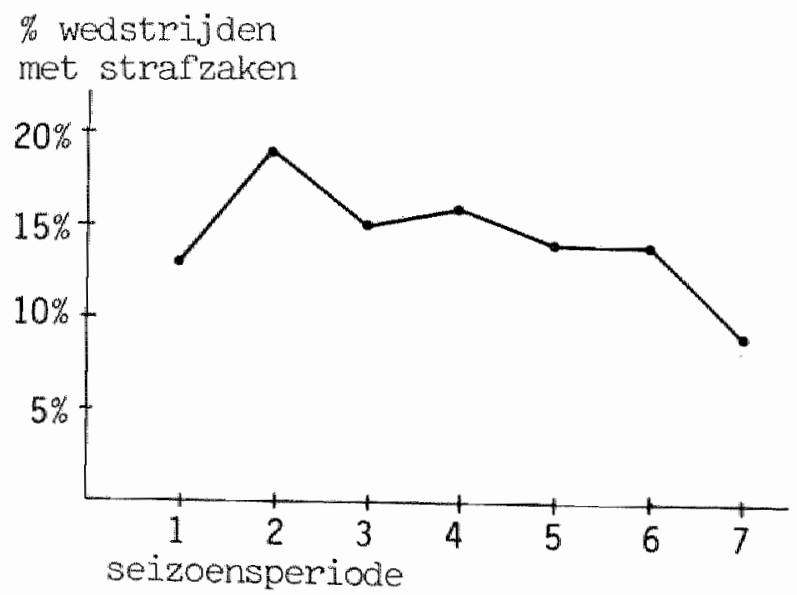


Tabe1 5.2 vereist een korte toelichting.

ledere periode betreft 3 a 4 volledige kompetitiezondagen. Daarbij is rekening gehouden met de periode van 6 weken waarin men niet heeft kunnen spelen (half december tot eind januari). Deze periode ligt tussen de perioden 3 en 4 uit tabe1 5.2. Na een dergelijke periode zou men kunnen vermoeden dat de "honger naar de bal" vertaald zou kunnen worden in een grotere kans op strafzaken.

Vooral in periode 2 is het aantal wedstrijden met strafzaken groter. We veronderstellen dat juist deze periode voor alle elftallen beslissend is of men ulteindelijk tat de "top" of tot de "staart" gaat behoren.

De laatste periode levert het minst aantal wedstrijden met strafzaken op; voor veel elftallen is de beslissing reeds gevallen, zodat het belang van de wedstrijd minimal is.

5.4. Rangplaatsverschil

Bij deze variabele moeten we, gezien onze onderzoekspopulatie, een tweetal opmerkingen maken:

1) degradatie op het vierde klassenivo is niet mogelijk

2) niet alle klassen (binnen de klassenivos) bevatten hetzelfde aantal ploegen $(70 \%$ van alle klassen bevat 12 verenig(ngen)

Hoewel de plaats op de ranglijst niet in de strafdossiers is vermeld zijn ze vila een apart geschreven computerprogramma aan het bestand toegevoegd. Aan het begin van de kompetitle is aan alle elftallen dezelfde plaats toegekend. 
Tabe1 5.3. (zie ook bijlage tabel 5.3.A)

\% wedstrijden met strafzaken naar verschil in plaats op rangl1jst $(\mathrm{N}=12.391)$.

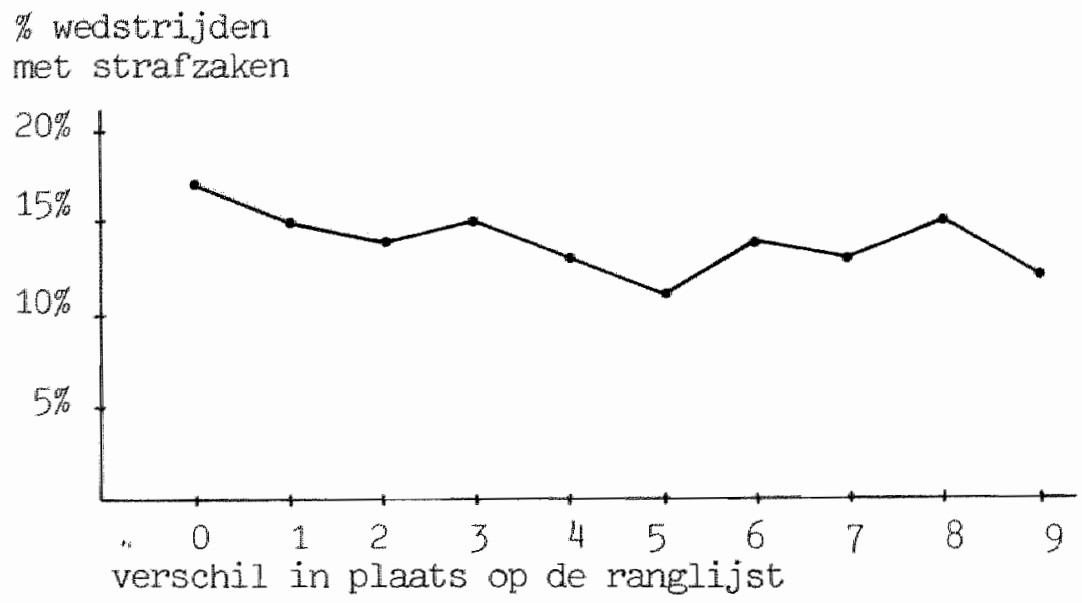

Tot een eenduidige konklusle kan tabel 5.3 niet leiden. Hoewel de twee uitersten (geen en een groot rangverschil) een duidelijk onderling verschil vertonen: wedstrijden tussen elftallen die in een gelijke positie op de ranglijst staan leveren verhoudingsgewijs meer strafzaken op, is het beeld tussen deze uitersten variabel.

\subsection{Afstand tussen de voetbalvelden}

De afstand hebben we vila kaarten van de topografische dienst (schaa 1 1:25.000) hemelsbreed gemeten aan de hand van de koördinaten van de Limburgse voetbalvelden.

Ondat de kompetitie zich grotendeels binnen de regio's afspeelt (zie par. 5.12), is de onderlinge wedstrijdafstand betrekkelijk klein: minder dan $8 \mathrm{~km}$.

Hoewel de tendens duidelifk $1 \mathrm{~s}$, naarmate de afstand tussen de velden groter wordt komen minder strafzaken voor, moet benadrukt worden dat er maksimaal slechts $2 \%$ versch 11 in de verschillende wedstrijdtypen aanwezig is. De assoclatiemaat tau (zie biflage tabel 5.4A) is niet signifikant. 
Tabel 5.4. (zie ook bijlage tabel 5.4A)

\% wedstrijden met strafzaken naar afstand ( $N=12.391)$.

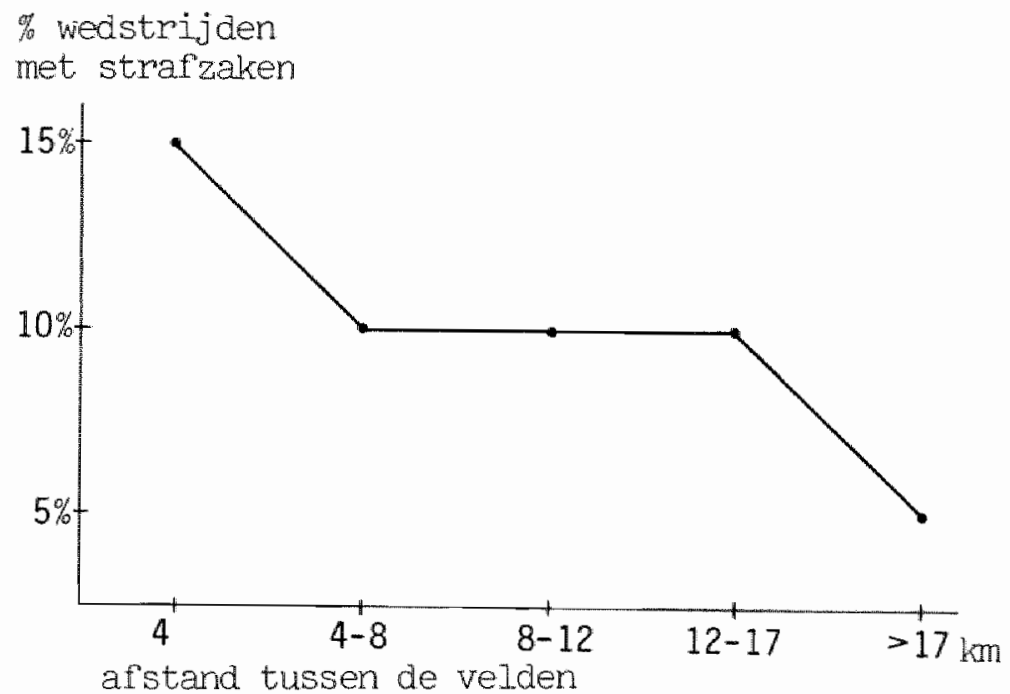

5.6. Aanta1 doelpunten, doelpuntenverschil, winst-verlies

De hiernavolgende variabelen aantal doelpunten, doelpuntenverschil en winst-verlies vertegenwoordigen zoals we in hoofdstuk 4 verwoord hebben, het wedstrijdbelang en zijn een indikatie voor het wedstrijdverloop. De variabelen zijn gebaseerd op de efnduitslag. Hiertegen zijn uiteraard bezwaren te opperen (zie o.a. Albrecht, 1982), omdat met name overtredingen het gevolg kunnen $z i j n$ van het doelpuntenverloop in een wedstrijd. Omdat in de strafdossiers geen melding wordt gemaakt van de doelpuntenstand op het tijdstip van de strafzaak bleef ons geen andere weg dan de einduitslag als variabele te gebrulken.

Onze veronderstelling bij deze varlabelen 1 s: een grotere kans op overtredingen treedt op, bij een gering aantal doelpunten, een klein doelpuntenverschil en bij wedstrijden waarin of door thuis of uitklub verloren wordt. 
Tabe1 5.5. (zie ook bijlage 5.5A)

$\%$ wedstrijden met strafzaken naar aantal doelpunten $(\mathrm{N}=12.391)$

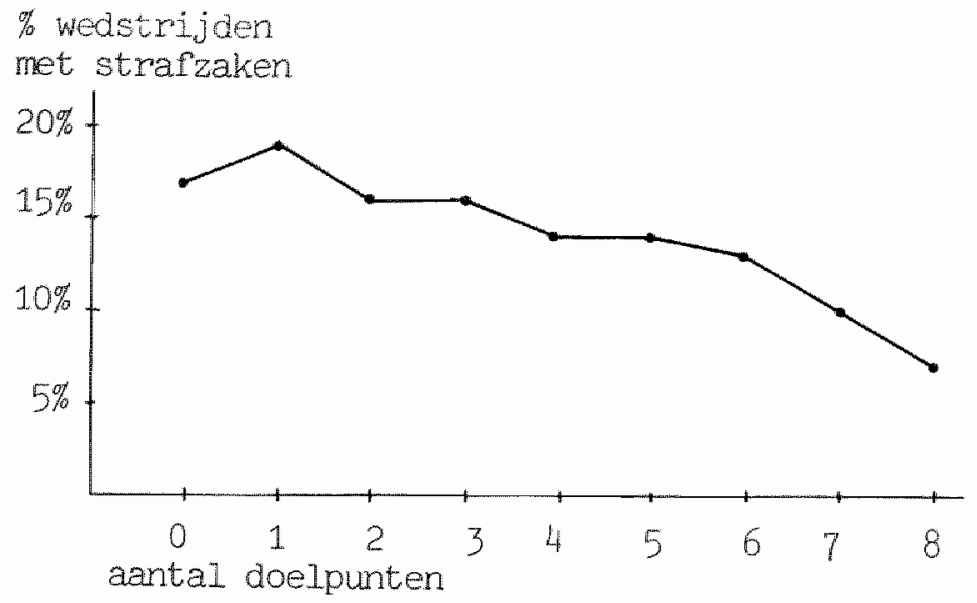

Tabe1 5.6. (zie ook bijlage 5.6A)

\% wedstrijden met strafzaken naar doelpuntenverschil $(N=12.391)$

$\%$ wedstrijden

met strafzaken

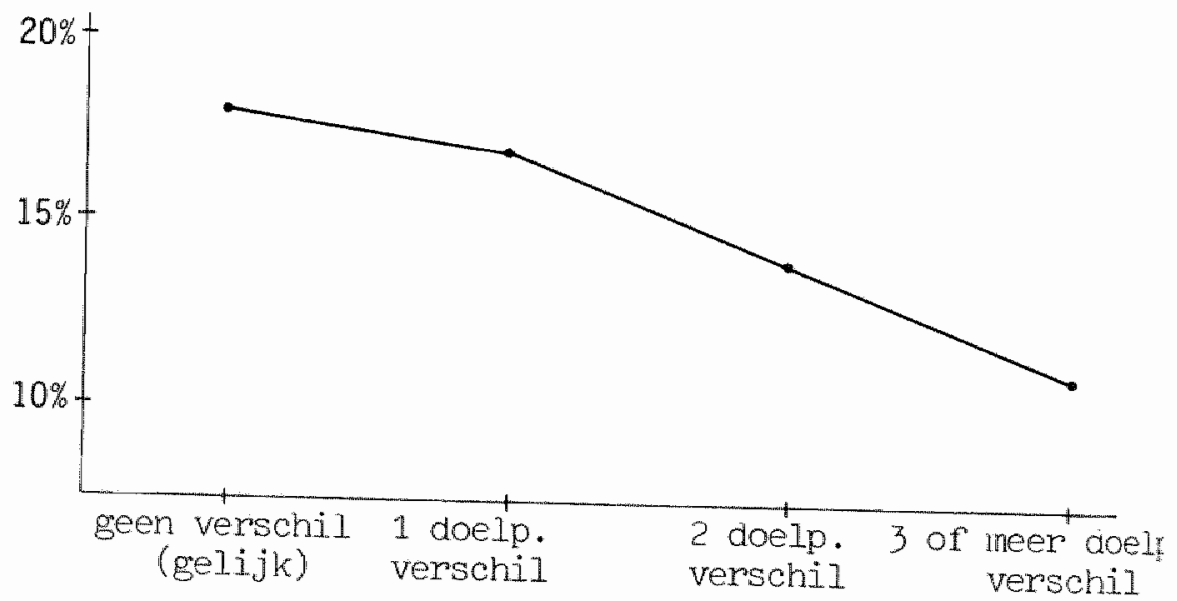


We zien dat bij een gering aantal doelpunten het aandeel van de strafzaken groter is. Na in totaal 3 geskoorde doelpunten wordt het aantal strafzaken relatief kleiner. We veronderstellen dat in de meeste gevallen, toename van het aantal doelpunten een definitieve beslissing in een wedstrijd weergeeft; daardoor zal de spanning verminderen en doorwerken op het minder begaan van overtredingen.

Onze veronderstelling dat, naarmate het doelpuntenverschil kleiner is de kans op overtredingen groter wordt, wordt op bivariaat nivo bevestigd.

Tabe1 5.7 .

Wedstrijden met en zonder strafzaak naar winst- of verliesfaktor $(\mathrm{N}=12.293)$

winst/verlies

met strafzaken $\%$

winst thuisklub gelijk verlies thuisklub

$\mathrm{Tc}=-.001 \mathrm{n} \cdot \mathrm{s}$. wedstrijden zonder strafzaken totaal $\%$

(N)

86

5.608

$18 \quad 82$

2.183

13

86

4.502

12.293

Een gelijk spel betekent in de meeste gevallen dat beide partijen tijdens de wedstrijd kans hebben gehad op de winst - dit wederzijdse belang wordt uitgedrukt in een groter aantal strafzaken.

Een tweede konstatering is van geheel andere orde: Wanneer we de aantallen van de totaalkolom bekijken, blijkt dat $46 \%$ van de wedstrijden door de thuisklub wordt gewonnen en $37 \%$ door de ultspelende klub. Ook in de afdeling bestaat er het zogenaamde thuisvoordeel. (Hoofdstuk 8 gaat hier nog nader op $\ln$.)

De volgende 2 variabelen verenigingsgrootte en urbanisatiegraad vertegenwoordigen de wedstrijdkontekst (zie hoofdstuk 4). 
5.7. Veren1gingsgrootte

De gemiddelde verenigingsgrootte in de afdeling ligt rond de 4.5 (met een spreiding van 1 tot 11 teams per vereniging). Klelne verenigingen bestaan uit 4 teams of minder; grote verenigingen bezitten méer dan 4 teams.

Uit overzicht 4.1 herhalen we de hypothese dat met name kleine verenigingen meer bij strafzaken betrokken zullen zijn.

Tabe1 5.8.

Wedstrijden met en zonder strafzaak naar verenigingsgrootte $(\mathrm{N}=12.391)$

Grootte verenigingen

$\begin{array}{lll} & \text { wedstrijden } & \\ \text { met } & \text { zonder } & \\ \text { strafzaken } & \text { strafzaken } & \text { totaal } \\ \% & \% & \text { (N) }\end{array}$

beiden klein

17

83

4.450

klein vs. groot

14

86

2.312

groot vs. klein

15

85

2.315

beiden groot

10

3.314

$(1.750) \quad(10.641) \quad 12.391$

$\mathrm{Tc}=.05$

Tabe1 5.8 geeft aan dat wedstrijden tussen kleine verenigingen meer strafzaken opleveren dan wedstrijden tussen grote verenigingen.

Hoewel de hoogte van de associatiemaat wijst op een relatief zwak verband, worden onze veronderstellingen bevestigd. Overigens geven de kategorieën 2 en 3 nog een klein verschil te zien; in kategorle 3 warin de grote vereniging thuisspeelt komen 45 wedstrijden met strafzaken meer voor; het is hierbij de vraag of de grote dan wel de kleine vereniging voor dit verschll verantwoordelijk is.

\subsection{Urbanisatiegraad}

Bif de vaststelling van deze variabele hebben we de CBS-norm van urbanisatiegraad (CBS, 1980) gehanteerd, vór de herindeling van Limburgse gemeenten. Omdat niet in alle regio's 
het platteland vertegenwoordigd is, hebben we besloten alle verenigingen afkomstig uit gemeenten met een stedelijk karakter te plaatsen tegenover verenigingen ult plattelands en/of verstedelijkte plattelandsgemeenten.

Onze veronderstelling is dat vooral spelers uit stedelijke verenigingen de kans op strafzaken groter doen worden.

Tabe1 5.9 .

Wedstrijden met en zonder strafzaken naar urbanisatiegraad $(\mathbb{N}=12.278)$

urbanisatiegraad

vereniging

beiden platteland

plat teland-stad

stad-platteland

beiden stad

$T_{c}=.003 \mathrm{n} . \mathrm{s}$. wedstrijden zonder

strafzaken

$\%$

totaal

(N)

5.387

2.272

2.271

2.348

86

(10.541)

Het onderscheid in urbanisatiegraad laat weinig verschillen zien in het al dan niet voorkomen van strafzaken.

Interessant is overigens wel dat daar waar platteland en stad elkaar ontmoeten er meer strafzaken voorkomen wanneer "het platteland" thuis speelt. Ook hier evenals bij de variabele verenigingsgrootte, is het de vraag wie voor dit grotere aantal strafzaken verantwoordelijk is. Is het de plattelands- of de stedelijke vereniging?

Als laatste hiler te behandelen variabele volgt een beschrijving van de variabele status scheidsrechter.

\subsection{Status scheidsrechter}

Gezien het tekort aan officièle scheidsrechters (N=447) ("officleel", door het volgen van een speclale scheldsrechterskursus), wordt er ook een beroep gedaan op nlet-officiele scheidsrechters, de zgn. wedstrijdleiders, die door de thuisklubs worden aangewezen. 
Per zondag vinden er dan nog individuele afmeldingen plaats zodat gemiddeld $60 \%$ van de wedstrijden door officiële scheidsrechters wordt geleid.

Wanneer we nagaan in hoeverre officielle scheidsrechters en wedstrijdleiders bij wedstrijden met strafzaken betrokken zijn, dienen we met een tweetal punten rekening te houden:

1. op het eerste en tweede klassenivo worden altijd officiele scheidsrechters aangesteld, terwijl tevens op het derde en vierde klassenivo waar men "iets" verwacht, gezien omstandigheden uit eerdere wedstrijden of gezien de stand van de ranglijst, ook officlële scheidsrechters worden aangewezen;

2. officiële scheidsrechters beginnen, ná de scheidsrechterskursus, op het laagste klassenivo met het leiden van wedstrijden en krijgen daarna de mogelijkheid, al naar gelang hun -beoordeelde- prestaties, op een steeds hoger klassenivo als scheidsrechter op te treden. Tevens bestaat voor hen de mogelijkheid daarna te promoveren naar het KNVB-voetbal (eventueel het betaalde voetbal). De niet-officièle scheidsrechters daarentegen fluiten slechts zeer incidenteel wedstrijden.

Deze beschrijuing van de scheidsrechterssituatie, versterkt ons vermoeden (zle hoofdstuk 4) dat niet-officiële scheidsrechters minder strafzaken aanhangig zullen maken.

Tabe1 5.10 .

Wedstrijden met of zonder strafzaak naar status scheidsrechter $(\mathrm{N}=12.372)$

Status scheidsrechter

officiele scheidsrechter niet-officiële scheldsr.

$T_{C}=.23$

met
strafzaak
$\%$

wedstrijden zonder strafzaak totaal $\%$

(N)

\begin{tabular}{|c|c|}
\hline 0 & 80 \\
\hline 3 & 97 \\
\hline$(1.750)$ & $(10.622)$ \\
\hline
\end{tabular}

Alhoewe1 een oververtegenwoordiging van officiële scheidsrechters verwacht mag worden is hun aandeel (vergeleken met de niet-officlële scheidsrechters) opvallend hoog. 
Van de in totaal 1.750 wedstrijden met strafzaken worden hiervan slechts $142(8 \%)$ door niet-officiëlen gerapporteerd.

De resultaten van par. $5.2 \mathrm{t} / \mathrm{m} 5.9 \mathrm{z} i \mathrm{jn}$ samengevat in tabel 5.11 .

Tabe1 5.11.

Samenhang van tien onafhankelijke variabelen en wedstrijden met en zonder strafzaak.

Onafhankelijke variabelen

mate van samenhang met wedstr. met/zonder strafzaak

tau B tau C P

1. klassenivo

2. selzoensverloop

.17

3. rangverschil

.04

4. afstand

.03

5. aanta1 doelpunten

.007

n.s.

6. doelpuntenverschil

.06

.06

7. winst/verlies

8. verenigingsgrootte

$-.001$

.05

9. urbanisatiegraad

.003

10. status scheldsrechter

.23

$\mathrm{n} \cdot \mathrm{s} \cdot$

n.s. niet signifikant

De variabelen klassenivo en scheldsrechter vertonen van de onafhankelijke variabelen de meest duidelijke samenhang met het al dan niet voorkomen van wedstrijden met strafzaak: op een hoog klassenivo en bij offictële scheidsrechters komen meer strafzaken voor.

De richting van de andere variabelen waarvan de hoogte van de associatiemaat tau niet boven de .06 uitkomt $1 \mathrm{~s}$ als volgt samen te vatten: meer strafzaken komen voor in het begin van het selzoen, bij een klein rangverschil, bij een gering aantal doelpunten, bij een klein versch 11 in doelpunten en bij wedstrijden tussen kleine verenigingen.

5.10. Onderlinge samenhangen van de onafhankeli jke variabelen.

In tabe1 5.12 (bijlage) $z i j n$ de nulde-orde koëfficiënten (Pearson-r) weergegeven. Drie samenhangen berelken een hoge 
re warde dan .30 . Allereerst de samenhang tussen de varlabelen aantal doelpunten en doelpuntenverschil- een samenhang die overigens logies genoemd kan worden; een klein aantal doelpunten correleert met een klein doelpuntenverschil $(.54)$.

Omdat bij belde variabelen, zoals we in het vorig hoofdstuk gezten hebben, verschillende hypothesen geformuleerd kunnen worden, hebben we besloten beiden in het onderzoek te blijven opnemen, te meer omdat we daarom in staat zijn te kunnen bepalen welke variabele meer of minder belangrijk is.

Een tweede verband is dat tussen klassenivo en scheidsrechter: op de hoogste klassenivos ( 1 en 2 ) worden uitsluitend officielle scheidsrechters aangesteld (.52).

Een laatste hoge samenhang is die tussen afstand van de velden en urbanisatiegraad; ook deze samenhang kan vrij 1ogles genoemd worden: een kleine afstand tussen de voetbalvelden vinden we vooral in de stad $(-.32)$.

De overige verbanden bereiken geen hogere warden dan .17 . Vermeldenswaard is nog dat het aantal doelpunten en het doelpuntenverschil zowel verband houden met het klassenivo (respektlevelijk.17 en .13) als met het verschil in plaats op de ranglijst (respektievelijk .08 en .11). Verklaringen hiervoor kumnen zijn dat op de hogere klassenivos de ploegen meer aan elkaar gewaagd $z i j n$, fmmers er wordt minder gescoord en de verschillen zijn klein. Deze konklusie gat ook op voor ploegen die dicht bij elkaar op de ranglijist staan.

\subsection{Scheidsrechtersenquete}

In het (afdelings)voetbal wordt, zonder dat dit expliciet naar buften komt, vaak melding gemakt van elftallen of klubs die een zekere reputatie opgebouwd hebben ten aanzien van het opgelegd krijgen van officiële straffen. Oorspronkelijk lag het daarom in de bedoeling kennis te krijgen van de verhoudingen of rivaliteiten tussen bepalde klubs.

Omdat we veronderstelden dat vooral scheidsrechters kennis zouden hebben van bestaande rivaliteit tussen verenigingen (ztch uitend in strafzaken) hebben we in het voorjaar van 1983 een enquête gehouden onder een vijftigtal scheidsrechters ( 10 per regio) uit de afdeling Limburg. De matige respons $(52 \%)$ en de verscheidenheld van de reakties zelf maakte het ons niet mogelijk de gegevens op eenduidige wijze verwerkt te krijgen in ons materlaal. Vier van de 26 reakties 
makten duidelijk dat van rivaliteit geen sprake zou zijn. De overige 22 reaktles moesten we, ondat de meeste scheidsrechters slechts ervaring hebben in eén regio, splitsen in vijf regio"s, zodat het aldus gerangschikte materiaal weinig generalisatie toeliet. Wel wordt in de diverse toelichtingen diverse malen gesproken over een derby tussen kerkdorpen uit eén gemeente, waarin impliciet de rol van het publiek naar voren komt.

\subsection{Regionale kompetities}

Voordat we nu wllen overgaan tot een multi-varlate analyse van het materiaal willen we een beschrijuing geven van de kompetitie in de afdeling Limburg.

Zoals in hoofdstuk 1 (par. 1.2.4) reeds summier is aangegeven, geschiedt de afwerking van de kompetitle binnen 5 reglo's. Beschrijuing van deze regios met hierin opgenomen de werk1ng van de onafhankelijke variabelen, zal tevens duldelijk maken of de analyses per reglo verricht gaan worden. Immers grote verschillen in bijvoorbeeld aantallen strafzaken per regio zouden hiervoor een aanlelding kunnen zijn.

\subsubsection{A1gemeen}

De regionale indeling heeft betrekking op de behandeling van strafzaken door zogenaamde regionale tuchtkommissies. De gemeentelijke herkomst van de thuisspelende klub bepaalt in welke kommissie de strafzaak behandeld wordt.

Bij de indeling in klassen geldt doorgaans de ruimtelifke afstand tussen de voetbalvelden van de verenigingen als kriterlum; dit kan betekenen dat in éfn klasse verenigingen uit verschillende regio's afkomstig zijn, hetgeen tevens impliceert dat gedurende een seizoen een strafzaak van een bepaald elftal door verschillende kommissies behandeld kan worden.

Omdat voor meer dan $80 \%$ van de klassen geldt dat zij bestaan uit elftallen van dezelfde regios, terwijl in de overige klassen Eén bepalde regio altijd de overhand heeft (gemiddeld $+67 \%$ ) bestaat de mogelijkheid om de verdere analyse per regio te verrichten. Naast een vergelijking van de werking van de onafhankelijke varlabelen op het voorkomen van strafzaken (de konsistentie van de variabelen), zou daardoor 
ook een vergelijkling mogelijk $z i j n$ van het bestraffingsbeletd van de reglonale tuchtkommissies.

Zoals we echter zullen aantonen geven de resultaten (tabel 5.13) geen voldoende reden om de analyse op regional nivo te doen plaatsvinden.

Alvorens deze resultaten te bespreken willen we in het kort de reglos beschrijuen.

\subsubsection{Beschrifuing reglos}

(bovenste gedee1te tabel 5.13)

Dit gedeelte geeft de belangrijkste kenmerken van de regios. Het aantal verenigingen in de kolom "totaal", korrespondeert niet met het totaal aantal verenigingen dat meedoet aan de afdelingskompetitie $(N=340)$. Af hankelijk van de kompetitieindeling wordt een aantal elftallen uit verenigingen ondergebracht bij een andere regio, dan waartoe ze eigenlijk behoren. Dit betekent, dat in de kolom "totaal" een aantal verenigingen dubbel is geteld.

Reg10 1.

Deze, qua aantal wedstrijden, grootste regio, omvat het meest noordelijke deel van Limburg; Venlo is de enige gemeente met een stedelijk karakter, hetgeen tevens impliceert dat de regio vooral een plattelandskarakter heeft.

Zowe 1 de gemiddelde afstand a1s de gemiddelde verenigingsgrootte liggen boven het provinclaal gemiddelde; doordat de verenigingen groot $z i j n$ is ook het aandeel van de lagere klassentvo's ( 3 en 4) groot.

Dit heeft weer tot gevolg dat bijna de helft van alle kompetitiewedstrijden door wedstrijdleiders wordt gefloten.

Reg10 2.

De steden Roermond, Weert en Echt zijn de centrale gemeenten in deze regio.

In b1jna alle opzlchten neemt deze regio vergeleken met de andere reglo's een tussenpositfe in ten aanzien van de verschillende kenmerken.

Reg10 3.

Deze regio (met o.a. de gemeenten Geleen, Brunssum en Sittard) is verreweg de kleinste regio ( $13 \%$ van het totaal aanta 1 wedstrifden). De gemiddelde verenigingsgrootte ligt onder het provinctaal gemiddelde. 
Tabe1 5.13.

Kenmerken en werking van de onafhankelijke variabelen in de reg10's

Onafh.variab. Regio 1. Regio 2. Regio 3. Regio 4. Regio 5. -aantal kompe-

\begin{tabular}{|c|c|c|c|c|c|}
\hline $\begin{array}{l}\text { titlewedstr. } \\
\text { \% tot.kompet. } \\
\text { verhouding } \\
\text { aant. wedstr. } \\
\text { k1.nivo len2 }\end{array}$ & $\begin{array}{r}.345 \\
27 \%\end{array}$ & $\begin{array}{l}2.746 \\
22.2 \%\end{array}$ & $\begin{array}{r}1.602 \\
12.9 \%\end{array}$ & $\begin{array}{l}2.400 \\
19.4 \%\end{array}$ & $\begin{array}{r}2.298 \\
18.5 \%\end{array}$ \\
\hline $\begin{array}{l}\text { tov } 3 \text { en } 4 \\
\text { aant.verenig. }\end{array}$ & $\begin{array}{c}5-65 \% \\
64\end{array}$ & $\begin{array}{c}39-61 \% \\
75\end{array}$ & $\begin{array}{c}41-59 \% \\
65\end{array}$ & $\begin{array}{c}44-56 \% \\
89\end{array}$ & $\begin{array}{c}34-66 \% \\
73\end{array}$ \\
\hline $\begin{array}{l}\text { emid.ver.gr. } \\
\text { emid.afstand } \\
\text { ussen velden }\end{array}$ & 6.0 & 5.0 & 3.6 & 3.9 & 4.1 \\
\hline $\begin{array}{l}\mathrm{km} \\
\text { nt.wedstr. } \\
\text { leid door: }\end{array}$ & 11.2 & 9.4 & 7.4 & 5.9 & 6.3 \\
\hline $\begin{array}{l}\text { off.scheidsr. } \\
\text { wedstr.leiders } \\
\text { \% verenig. uit: }\end{array}$ & $\begin{array}{l}51 \\
49\end{array}$ & $\begin{array}{l}74 \\
26\end{array}$ & $\begin{array}{l}71 \\
29\end{array}$ & $\begin{array}{l}75 \\
25\end{array}$ & $\begin{array}{l}56 \\
44\end{array}$ \\
\hline attelandsgem. & 43 & 21 & - & 2 & 6 \\
\hline $\begin{array}{l}\text { ersted.plattel } \\
\text { em.met stedel. }\end{array}$ & - 38 & 47 & 59 & 46 & 43 \\
\hline $\begin{array}{l}\text { rakter } \\
\text { wedstr. met }\end{array}$ & 19 & 32 & 41 & 52 & 51 \\
\hline rafzaken & $\begin{array}{r}11 \% \\
(354)\end{array}$ & $\begin{array}{r}17 \% \\
(473)\end{array}$ & $\begin{array}{r}16 \% \\
(249)\end{array}$ & $\begin{array}{r}16 \% \\
(383)\end{array}$ & $\begin{array}{r}13 \% \\
(291)\end{array}$ \\
\hline
\end{tabular}

Samenhang tussen onafhankelijke variabelen en wedstrijden met en zonder strafzaken (tau B, tau C)

$\begin{array}{llllll} & \mathrm{N}=708 & \mathrm{~N}=946 & \mathrm{~N}=498 & \mathrm{~N}=766 & \mathrm{~N}=582 \\ \text { klassenivo } & .41 * * * & .36 * * * & .28 * * * & .36 * * * & .33 * * * \\ \text { seizoensver1. } & .009 \mathrm{~ns} & .08 * & .09 * & .05 \mathrm{~ns} . & .06 \mathrm{~ns} \\ \text { rangversch11 } & .02 \mathrm{~ns} & .05 \mathrm{~ns} & -.006 \mathrm{~ns} & .06 \mathrm{~ns} & .07 \mathrm{~ns} \\ \text { afstand } & -.02 \mathrm{~ns} & .008 \mathrm{~ns} & .03 \mathrm{~ns} & .04 \mathrm{~ns} & .09 * \\ \text { aantal doelp. } & .21 * * * & .07 * & .14 * * & .02 \mathrm{~ns} & .12 * * \\ \text { doelp.verschi1 } & .19 * * * & .12 * * & .14 * * & .04 \mathrm{~ns} & .12 * * \\ \text { winst/ver1ies } & -.04 \mathrm{~ns} & .04 \mathrm{~ns} & .04 \mathrm{~ns} & -.03 \mathrm{~ns} & .02 \mathrm{~ns} \\ \text { ver.grootte } & .06 \mathrm{~ns} & .15 * * * & -.05 \mathrm{~ns} & .08 * & .07 \mathrm{~ns} \\ \text { urbanisatiegr. }-.06 \mathrm{~ns} & .09 * * & -.03 \mathrm{~ns} & .04 \mathrm{~ns} & -.08 * \\ \text { status scheidsr...46***} & .29 * * * & .34 * * * & .30 * * * & .37 * * *\end{array}$

$$
\begin{array}{ll}
* * * & 0.00<\mathrm{p}<0.001 \\
* * & 0.001<\mathrm{p}<0.01 \\
* \quad & 0.01<\mathrm{p}<0.05
\end{array}
$$


Regio 4.

Naast Kerkrade 11 ggen ook de gemeenten Heerlen en Hoensbroek in deze reglo. Een groot aantal verenigingen en een gemiddeld lage verenigingsgrootte $z 1 j n$ specifleke kenmerken van deze reglo; tevens is het aandeel van wedstrijden op het eerste en tweede klassenivo groot; dit betekent, omdat officlele scheidsrechters vooral op het klassenivo 1 en 2 fluiten, een groot aandeel van deze kategorie. De gemiddelde afstand tussen de velden $11 \mathrm{gt}$ onder het provinciaal gemiddelde.

\section{Regio 5.}

In deze regio is Mastricht de enige stedelijke gemeente. Meer dan de helft van alle wedstrijden in deze regio vindt plaats in deze stad.

Vermeldensward is het relatief geringe aandeel van officiéle scheidsrechters, samenhangend met een (relatief) klein aantal wedstrijden op het eerste en tweede klassenivo.

\subsubsection{Werking onafhanke11 jke varlabelen per regio} (tabel 5.13 onderste gedee1te)

Dit gedeelte geeft de samenhangen an tussen de door ons gehanteerde 10 onafhankelijke variabelen (zie par. $5.2 \mathrm{t} / \mathrm{m}$ 5.9) en wedstrijden met en zonder strafzaken.

De aantallen ( $N$ ) die vermeld staan bovenaan het tweede gedeelte van tabel $5.13 \mathrm{zijn}$ op de volgende wijze verkregen: Uitgegaan is per regio van het aantal wedstrijden met strafzaken. Vervolgens is, per regio, uit de overige wedstrijden zonder strafzak een aselekte steekproef getrokken; de grootte van deze steekproef is zodanig, dat zij korrespondeert met het aantal wedstrijden warin strafzaken voorkomen. We maken dus gebruik van een steekproef.

Als we dat niet zouden doen, dan zouden we uttgaan van wedstrijden met en zonder strafzaken. Maar die verhouden zich als 1:7. Statistiese methoden, met name multivariate analyses zouden dan niet of slecht toepasbaar zijn (Klecka, 1980). Omdat we met ons materlaal onder andere diskriminantanalyses widen laten uitvoeren, is voor deze selektie van het materlaal gekozen.

Het officiele programmaboekje (per wedstrijdzondag) van de KNVB heeft als uitgangspunt gedlend of een wedstijd al dan niet door een officiele scheidsrechter wordt geleid. In dit 
programma staan voor iedere wedstrifdzondag alle te spelen wedstrijden vermeld, met daarachter de naan van de officlele scheidsrechter ( $t 64 \%$ van alle wedstrijden). In de praktijk schrifft een aantal scheidsrechters per wedstrijdzondag af, zodat we ervan uit moeten gaan dat ongeveer $60 \%$ van alle wedstrijden geleid wordt door een officiele scheidsrechter. De operationalisatie van de variabelen verschilt in de regio's bij een aantal variabelen enigszins; met name geldt dit voor de variabelen afstand, verenigingsgrootte en urbanisatiegraad. In de bijlage 5.13A hebben wij deze operationalisatie beschreven.

Wanneer we de resultaten van tabel 5.13 (onderste gedeelte) bekijken dan kunnen we opmerken dat 2 variabelen in alle regios signifikant $z i j n(p<.05)$, namelijk het klassenivo en de scheidsrechter; de waarden van de assoclatiematen, liggen hoger dan bij de andere variabelen (varierend van .28 tot .46). De richting van deze varlabelen is ook in alle regios dezelfde: wedstrijden met strafzaken worden gekenmerkt door een hoog klassenivo en de lelding door een officièle scheidsrechter. In 4 van de 5 regios $z i j n$ vervolgens de variabelen aantal doelpunten en doelpuntenverschil signifikant zij het, dat de hoogte van de associatiemat niet uitkomt boven de .21. Ook hier blijkt de richting van de variabelen identiek te $z i j n$ : wedstrijden met strafzaken worden gekarakteriseerd door weinig doelpunten en een klein doelpunten verschil.

De andere 5 variabelen zijn slechts in één of twee regios signifikant en dan nog in beperkte mate (de associatiemaat komt nergens hoger dan .10 ).

Een andere manier om de kleine verschillen in de reglos te laten zien is, per reglo, na te gaan welke verhouding bestaat tussen het aantal wedstrijden met en zonder strafzaak (tabel 5.14.). 
Tabe1 5.14 .

Wedstr1jden met en zonder strafzaak naar regio $(\mathbb{N}=12.391)$

Reg10

wedstrijden

$\begin{array}{lll}\text { met } & \text { zonder } & \\ \text { strafzaak } & \text { strafzaak } & \text { totaal } \\ \% & \% & (\mathrm{~N})\end{array}$

regio 1. Horst, Venray e.o. 11

regio 2. Roermond e.o. 17

regio 3 . Sittard e.o. 16

regio 4. Heerlen e.o. 16

regio 5. Maastricht e.o. 13

$14(1.750)$

89

3.345

$83 \quad 2.746$

$84 \quad 1.602$

$84 \quad 2.400$

$87 \quad 2.298$

$T_{c}=-0.02$

$86(10.641) 12.391$

Het percentage wedstrijden met strafzaken varleert in de regios tussen $11 \%$ (reglo 1 ) en $17 \%$ (reglo 2 ).

Uit de bespreking van de regios kan het volgende worden gekonkludeerd: De samenhang en richting van de onafhankelijke variabelen met het voorkomen van wedstrijden met en zonder strafzaken vertoont in de meeste reglos geen grote verschillen.

Ook de spreiding in de verhouding wedstrijden met en zonder strafzaken, tussen de regios, is gering (schommelend rond de $14 \%)$.

Gezien deze konsistentie van de resultaten is het derhalve nlet nodig de verdere analyses reglonal te doen geschieden, immers, veel ekstra informatie zal een dergelijke werkwijze niet opleveren. 5.13. Vergelijking van wedstrijden met en zonder straf-

In deze paragraaf wordt de probleemstelling: "Kunnen we bepaalde faktoren aanwijzen die het verschil verklaren tussen wedstrijden met en zonder strafzaken" getoetst.

Twee analyses staan hierbij centraal: de diskriminant analyse en de kontrastgroepenanalyse; de wedstrijd is analyseeenheid. 
Bij beide multi-variate analyses gat het om een procedure, waarbij in principe alle beschikbare variabelen meespelen, met het doel zo veel mogelijk variantie in een afhankelijke variabele te binden. Kenmerkend is (in ons geval) het stapsgewijze selekteren. Dit meespelen van alle onafhankelijke variabelen, waarbij rekening gehouden wordt met de onderiinge samenhangen, is een manco van veel onderzoeken die het agressief gedrag in de sport pogen te verklaren (Albrecht, 1982). De variabelen die men gebruikt worden meestal monokausaal geinterpreteerd (o.a. Begerau, 1981; Volkamer, 1971). Het onderscheid tussen de beide analyses dient te worden gezocht bij de voor regressietechnieken additionele assumpties van intervalmeetnivo der variabelen, lineariteit van de relaties en afwezigheid van interakties. Omdat we in het eerste gedeelte van dit hoofdstuk gezien hebben dat een aantal variabelen een duidelijke samenhang vertonen (aantal doelpunten en doelpuntenverschil; status scheidsrechter en klassenivo) én ondat een aantal variabelen nominaal is (scheidsrechter, urbanisatiegraad) hebben wij de techniek van de kontrastgroepenanalyse toegepast omdat zij beide elementen (onderlinge samenhang en verschillend meetnivo van onafhankelijke variabelen) in haar verwerking opneent.

Op de kontrastgroepenanalyse gaan wij in paragraaf 5.13 .2 uitvoeriger in.

\subsubsection{Diskriminantanalyse van wedstrijden met en zonder strafzaken}

Gezien de aard van onze eerste probleemstelling hebben wij op het materiaal een diskriminant analyse toegepast. Daarbij $z i j n$ we nagegaan welke variabelen wedstrijden met strafzaken doen verschillen van wedstrijden zonder strafzaken.

De in het vorige hoofstuk genoende variabelen zijn bij de analyse gebruikt. Zoals in hoofdstuk 1 is aangegeven was het door de aard van deze probleemstelling niet mogelijk de overigens belangrijk geachte variabele thuis - ultspelen mee te nemen $\mathbb{1 n}$ de analyse.

De opbouw (onderverdeling) van ledere variabele afzonderlijk, is identiek aan de beschrijuing van de varlabelen in paragraaf. $5.2 \mathrm{t} / \mathrm{m} 5.9$.

Tabel 5.15 geeft de gestandaardiseerde diskriminant funktie koëfficiënten van de varlabelen. De sterretjes achter de variabelen duiden op een signifikante bijdrage $(p<0.05)$ aan 
het onderscheid tussen wedstrijden met en wedstrijden zonder strafzaken (signifikante verandering in RAO's V').

Voordat we de resultaten van de analyse weergeven moeten we nog ultsluitsel geven omtrent het aantal wedstrijden dat aan de analyse $1 \mathrm{~s}$ onderworpen.

Gezien onze bevindingen dat de werking van de onafhankelijke varlabelen in de regios in grote mate overeenstemt, hebben wij besloten de aantallen die in de regios gebruikt zijn (zle tabel 5.13 - onderste gedeelte) samen te voegen tot éen bestand. Derhalve zal de diskriminantanalyse gebaseerd zijn op 3500 wedstrijden ( 1750 wedstrijden met en 1750 wedstrijden zonder strafzaak).

Tabe1 5.15.

Diskriminantana1yse wedstrijden met en zonder strafzaken (stapsgewifs) $(\mathrm{N}=3500)$

variabele

status scheidsrechter

klassenivo

doelversch11

seizoensverloop

afstand

aantal doelpunten

winst/verlies

verenigingsgrootte

rangplaats gestandaardiseerde diskriminantfunktiekoëfficient

.65

.48

.14

.10

.09 signifikante verandering. in RAO's V $(.000)$

$(.000)$

$(.0004)$

$(.005)$

$(.02)$

.06

.06

.05

.04

(.10)

$(.13)$

$(.24)$

$(.28)$

kanoniese korrelatie $=.39$

De varlabele scheldsrechter is de belangrijkste faktor die wedstrijden met strafzaken doet onderscheiden van wedstrijden zonder strafzaken.

Dit betekent dat officlële scheldsrechters (in tegenstelling tot de wedstrijdleiders) meer strafzaken aanhangig maken.

* De hierboven gestelde voorwarden die we aan de resultaten van de diskriminantanalyse gesteld hebben, gelden ook voor de analyses uitgevoerd in de hoofdst. 6,7 en 8 . 
De tweede varlabele die een duidelijk onderscheidend vermogen heeft is het klassenivo: op een hoog klassenivo komen meer wedstrijden met strafzaken voor. In felte zijn deze twee variabelen grotendeels bepalend voor het onderscheld tussen wedstrijden met en wedstrijden zonder strafzaak, immers de waarden van de koëfficlënten zijn bij deze twee variabelen duidelijk hoger dan bij de andere variabelen. (Hoe hoger de waarde, des te groter is de bijdrage van de variabele aan het onderscheid (Klecka, 1980).

Het feit dat de varlabelen doelpuntenverschil, selzoensverloop en afstand een signifikante bijdrage leveren aan het onderscheid tussen wedstrijden met en zonder strafzaken kan als volgt weergegeven worden: een klein doelpunten verschil; het begin van het seizoen en wedstrijden tussen 2 elftallen waarvan de velden dicht bij elkaar liggen, leveren meer strafzaken op.

Het kwadraat van de kanoniese korrelatie is een indikatie voor de verklaarde variantie; deze 1 igt in de gehanteerde diskriminantanalyse op $15 \%$.

Als we alleen zouden beschikken over de waarden van de variabelen die de diskrimlnantfunktie vormen dan zou het moge$11 \mathrm{jk}$ zijn met een kans van $67 \%$ goed te voorspellen of wedstrijden met of zonder strafzaak voorkomen. Wedstrijden met strafzaak zijn beter te voorspellen (76\%) dan wedstrijden zonder strafzaak $(57 \%)$.

Wat betekenen nu deze resultaten; in hoeverre komen ze overeen met onze veronderstellingen en met andere bevindingen op het gebied van de "voetballiteratuur". In tabe1 5.16 worden onze hypothesen ten aanzien van de kans op overtredingen (strafzaken), uit overzicht 4.1 , per variabele, vergeleken met de resultaten.

Indien de variabele gện signifikant diskriminerend vermogen bezit wordt dit aangegeven door een 0 -teken. 
Tabe1 5.16 .

Vergel1jking hypothesen en resultaten omtrent kans op overtreding (strafzaken) (per onafhankeli jke variabele)

$$
\begin{aligned}
& \text { hypothese }>\text { kans } \\
& \text { op strafzaak }
\end{aligned}
$$

1. wedstrijdbelang

klassenivo

selzoensverloop

rangverschil

af stand

wedstr1 jdverloop

aantal doel punten

doelpuntenverschil

winst-verlies

2. soclale kontekst

verenigingsgrootte urbanisatiegraad

3. arbitrage

$\begin{array}{ll}\text { hoog } & j a \\ \text { begin } & j a \\ \text { klein } & 0^{*} \\ \text { klein } & j a \\ \text { klein } & 0 * \\ \text { gering } & j a \\ \text { verlies } & 0^{*} \\ \text { klein } & 0^{*} \\ \text { stad } & 0^{*} \\ \text { status scheidsr. } & j a\end{array}$

hypothese

bevestigd?

ja

ja

ja

0 *

ja

0 *

ja

* variabele in de diskriminantanalyse niet signifikant.

Naast de variabele scheldsrechter blijken vooral die variabelen een signigikant diskriminerend vermogen te bezitten die het belang van de wedstrijd weergeven. Het is opvallend dat de twee varlabelen die de sociale kontekst bepalen (verenigingsgrootte en urbanisatiegraad) geen signifikante bijdrage leveren aan het onderscheld tussen wedstrijden met en zonder strafzaken.

- Onze veronderstellingen ten aanzien van de variabele status scheldsrechter lijken juist te zijn. Het is, mede door de aard van ons onderzoeksmateriaal niet mogelijk na te gaan welke oorzaak bij deze variabele van primair belang is danwel of meerdere oorzaken samengaan:

Is het geen ervaring hebben (c.q. de mogelijk slechte kennis van de spelregels) er de oorzaak van dat niet-officlëlen minder waarnemen en dus beoordelen. Speelt het interne rolkonflikt, inherent aan de scheidsrechtersrol mee - immers, ledere beslissing voor de ene partij, werkt in het nadeel van de andere partif; of is met name de versterking van het interne rolkonflikt voor de niet-officiële scheidsrechter belangrijk: de binding met de thuisklub zorgt ervoor dat nauwelijks in het spel wordt ingegrepen via officiele be- 
slissingen. Of met name dit laatste rolkonflikt meespeelt kan duidelijk worden aan de hand van de grootte van het verschil in feitelijke strafzaken tussen thuis- en uitspelers (hoofdstuk 8). Daarnaast zal de mate van (emotionele) binding met de thuisklub (persoonlijke kennis van de spelers) van invloed $z i j n$ op het bestraffingsbeleid.

- Wanneer we de andere signifikant gebleken variabelen bezlen dan kunnen we vaststellen dat het klassenivo, het doelpuntenverschil en het seizoensverloop en de afstand beschouwd kunnen worden als variabelen die het belang van een wedstrijd aangeven.

Vergeleken met ons literatuuroverzicht is dit voor de variabele klasse in overeenstemming met bevindingen van Lefebvre (1974) en Volkamer (1971) en in tegenstelling tot de resultaten van Ekkers en Hoefnage1s (1972) en Wolf (1962).

Gezien de duidelijke richting van het klassenivo (op een hoog klassenivo komen meer wedstrijden met strafzaken voor) moeten we in ieder geval voor het amateurvoetbal de veronderstelling van Wolf (1962) ontzenuwen dat in de lagere klassen door gebrek aan techniek spelers zichzelf minder in bedwang zouden hebben, hetgeen in meer strafzaken zou resulteren. Wel moeten we erop bedacht zijn dat de aard van zijn onderzoeksmateriaal verschillend is van onze gegevens. Wolf, heeft met name de meer ernstige overtredingen in zijn populatie opgenomen (zie hoofdstuk 3 ).

$B i j$ een hoog klassenivo nemen we allereerst aan dat spelers op dit nivo spelen op grond van bewezen spelkwaliteiten. In de loop der jaren hebben $z i j$ zich bepalde sportnormen elgen gemaakt die agressteve handelingen onder druk van belang cq. winst rechtvaardigen (Kahler, 1982; Pilz, 1982). In die zin kan men spreken over sportsociallsatie.

De invloed van een klein doelpuntenverschil is in overeenstemming met bevindingen van Begerau (1981), Gabler (1976) en Volkamer (1971). Tevens betekent dit dat de stelling van Volkamer, dat ieder doelpunt leidt tot frustratie in leder geval voor ons onderzoek niet opgaat.

Dat vooral het begin van het selizoen samenhangt met een grotere kans op strafzaken, bevestigt ons vermoeden dat juist aan het begin voor alle elftallen het wedstrijdbelang groot is.

Een geringe afstand tussen de velden houdt wellicht verband met een bepalde rivalitelt tussen verenigingen. Wolf (1962) spreekt in dit verband van "Lokalderbys". 
5.13.2. Kontrastgroepenanalyse van wedstrijden met en zonder straf zaken

Om de varlantie in de afhankelijke variabele te verklaren werd tevens gebruik gemakt van de kontrastgroepenanalyse (Segers en Stouthard, 1963; Segers, 1964).

De gedachtengang bif deze techniek is dat, volgens Segers (1964):

a) een methode van analyse niet mag stranden op interakties of deze wegveronderstellen, maar interakties zoveel mogelijk aan het licht dient te brengen;

b) zij toepasbaar dient te zijn op gegevens die verschi1lende nivos van meten bestrijken;

c) zij optimaa1 dient te zijn in die zin dat afgezien van teoretlese of praktlese overwegingen het gestelde doe1: het verklaren van de afhankelijke variabele, zo efficlent mogelifk wordt berelkt.

Kontrastgroepenanalyse onderzoekt de gelijktijdige werking van een aantal onafhankelijke variabelen op een afhankelijke varlabele.

De analyse bestaat uit afzonderlijke stappen, waarbij bij ledere stap gezocht wordt naar die dichotomie, welke het best kontrast geeft in de variantie van de afhankelijke variabele (Burroughs, 1980).

In ons onderzoek worden de wedstrijden op basis van eén van de onafhankelifke variabelen (de variabele die de grootste samenhang vertoont met het al of niet voorkomen van strafzaken) zo ingedeeld in twee groepen dat het verschil ten aanzlen van de afhankelijke variabele zo groot mogelijk is.

Vervolgens worden deze 2 groepen op dezelfde wijze gesplitst en wel op basis van die variabele die dan de grootste samenhang met de afzonderlijke variabele vertoont. De splitsing loopt totdat de verklaarde variantle te klein wordt of het aantal wedstrifden te gering. Aldus wordt een boomstruktuur verkregen.

Alvorens over te gaan tot presentatie van de resultaten willen we nog enige opmerkingen ten aanzien van onze werkwijze maken.

In ons onderzoek mag (b1j splitsing) het maksimaal aantal per groep 50 bedragen, dit om het bezwaar weg te nemen dat gekapltaliseerd wordt op toeval, dat wil zeggen als gevolg van het ingebouwde selektieprinclipe toevallig optredende verschillen op onevenredige wijze worden gehoneerd. Bij een 
eerste poging om deze methode toe te passen bleek dit bezwar inderdaad gegrond. Vergeleken met de diskriminantanalyse is de variabele aantal doelpunten niet meegenomen in de analyse. Het computerprogramma Basis waar de kontrastgroepenanalyse (Automatic Interaction Detection) een onderdeel van vormt biedt slechts mogelijkheid aan een beperkt aantal mengformaties van de vartabelen. Omdat juist deze variabele (gezien de grote verscheldenheid aan ultslagen) een groot aantal transformatles vereist, bleek dit in kombinatie met de transformaties van de andere varlabelen het maksimaal toelaatbare te overschrijden.

ondat we echter de beschlkking hebben over de variabele doelpuntenversch11 (die samenhangt met de hiervoor genoemde variabele) blifft de vergelijking van de belde analyses reëe1.

Figuur 5.1 .

Kontrastgroepenanalyse wedstrijden met en zonder strafzaken $\overline{(\mathrm{N}}=3500)$

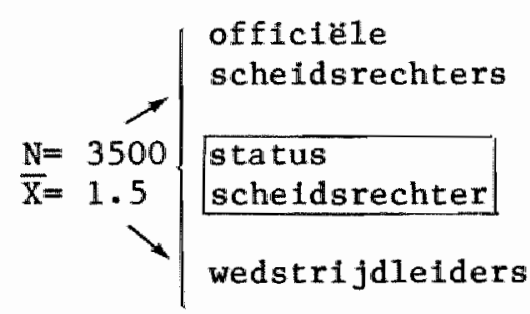

stap 1:

verklaarde variantie $12 \%$

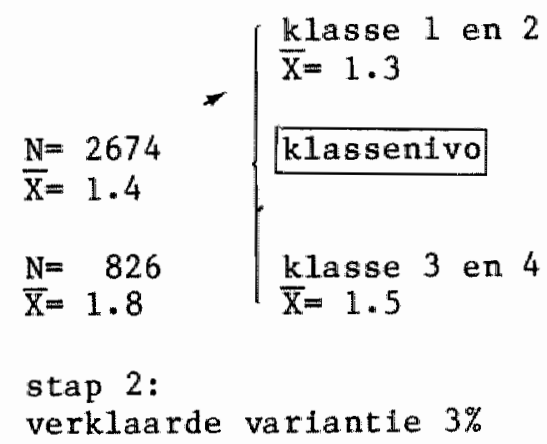

Flguur 5.1 geeft de resultaten van de kontrastgroepenana1ysie.

Indien een variabele een splitsing teweegbracht hebben wij In het bovenste gedeelte van de splitsing het onderdeel van de dichotomie gezet die nauw samenhangt met het voorkomen van strafzaken.

De analyse begint met een gemiddelde van 1.5. Gemiddelden boven 1.5 wijen op een samenhang met niet-strafzaken; beneden de 1.5 op een samenhang met strafzaken. 
Slechts 2 stappen zijn nodig om de kontrastgroepenanalyse te laten beindigen. Voor de beIndiglng gelden 2 voorwaarden: of het minimum aantal van 50 per groep wordt niet meer gehaald, 6f er wordt niet meer dan $1 \%$ variantie verklaard.

De variabelen status scheidsrechter en klassenivo $z i j n$ verantwoordelijk voor de verklaarde variantie.

Het zal, mede gelet op de resultaten van de diskriminantanalyse geen bevreemding wekken dat officiële scheidsrechters en/of een hoog klassenivo een lager gemiddelde bevatten (een samenhang met strafzaken).

De kontrastgroepenanalyse die o.a. interakties tussen variabelen zoveel mogelijk aan het licht dient te brengen, makt duldelijk dat de variabele scheidsrechter in de analyse verult de grootste rol speelt. Van de total verklaarde variantie, $15 \%$, hetgeen overigens in overeenstemming is met de resultaten van de diskriminantanalyse, neemt de variabele scheldsrechter verreweg het grootste deel voor haar rekening (name11.jk $12 \%$ ).

De kontrastgroepenanalyse dichotomiseert het klassenivo in enerzijds le en $2 e$ klassenivo en anderzijds $3 e$ en $4 \mathrm{e} k \mathrm{klasse}-$ nivo.

Ons vermoeden dat het vooral op het $4 \mathrm{e}$ klassenivo weinig strafzaken voorkomen (immers degradatie is niet mogelijk op dit klassenlvo) wordt slechts gedeeltelijk bevestigd. Immers wanneer dit laagste nivo een duidelijke afwijkende positie Innam had de kontrastgroepenanalyse de dichotomie le, $2 \mathrm{e} 3 \mathrm{e}$ ten opzichte van $4 \mathrm{e}$ klassenivo gekonstrueerd.

\subsection{Samenvatting}

Zowel de diskriminant- als kontrastgroepenanalyse toont aan dat de verklaarde variantie ongeveer $15 \%$ bedraagt. In hoofdstuk 1 is opgemerkt dat het woorkomen van strafzaken dermate afhankelijk is van een scala van situationele faktoren, zowel betrekking hebbend op spelers- als scheidsrechtersgedrag, dat de inhoud van ons onderzoeksmateriaal slechts in beperkte mate verklarende faktoren voor onze probleemste1ling kan bevatten. Derhalve kan men redelijk tevreden zijn met het door ons verkregen resultaat. 
De kontrastgroepenanalyse toont aan dat bijna uitsluitend de variabele status scheldsrechter verantwoordelijk is voor het onderscheid wedstrijden met en zonder strafzaken.

Een dergelijk resultaat geeft, althans geldend voor ons onderzoeksmateriaal, aan dat de rol van de scheldsrechter in de diskussie over het hoe en warom van strafzaken een belangrijk element moet vormen.

Door de belangr 1 jkheid van de status scheidsrechter wordt tevens aangetoond dat variabelen die (in)direkt het spelersbelang betreffen, dus mogelijk met agressleteorieën samenhangen, in mindere mate als verklaring voor het voorkomen van strafzaken dienen. Vooral het klassenivo blijkt een redelijk belangrijke faktor te $z i j n$.

Om na te gaan wat het onderscheidend vermogen is van de verschillende variabelen indien we de varlabelen scheidsrechter en klassenivo transformeren, hebben we een aantal analyses toegepast.

In éen analyse is de variabele status scheidsrechter onderverdeeld in 5 kategorleën (4 kategorieën officiële scheidsrechters enerzijds -iedere scheidsrechter begint zijn loopbaan met het leiden van wedstrijden in de $4 \mathrm{e}$ (laagste) klasse en kan geleidelijk doorpromoveren naar de hogere kategorieën 3,2 en 1 ; en een kategorie niet-officiële scheidsrechters anderzijds).

Dit onderscheld levert zowel in de verklaarde variantie als in de signifikante verklarende varlabelen nauwelijks verschil op met de eerder besproken analyses. De kontrastgroepenanalyse dichotomiseert de variabele status scheidsrechter in offictëlen en niet-officiëlen! Indien alléen officièlen in de analyse worden opgenomen bedraagt de verklaarde variantie $4 \%$ - de kontrastgroepenanalyse dichotomiseert het klassenivo in le en $2 e$ ten opzichte van $3 e$ en $4 \mathrm{e}$ klasse. Nemen we in de analyse alleén le en $2 \mathrm{e}$ klassen op (dus alleén officiële scheldsrechters) dan bedraagt de verklaarde varlantie in de diskriminantanalyse $1 \%$ en komt de kontrastgroepenanalyse tot geen signifikante splitsing.

Dit betekent dat, in ieder geval wat het rapporteren van strafzaken betreft, de officiële scheldsrechters een vrij uniform bestraffingsbeleid hanteren. Deze konstatering laat echter (nog) geen konklusies toe over de samenhang tussen officiële scheldsrechters en specifleke strafzaakkenmerken zoals scheidsrechterlijke sanktle en/of de aard en richting van de strafzaak. 
HOOFDSTUK 6.

KENMERKEN STRAFZAKEN EN HET AANTAL STRAFZAKEN PER WEDSTRIJD

6.1. Inleiding

Tot dusverre hebben wif aandacht besteed aan onze eerste vraagstellingen met de vergelijking tussen wedstrijden met en zonder strafzaken als onderwerp.

Na deze vergelijking willen wij ons in dit hoofdstuk richten op wedstrijden met strafzaken.

Het onderhavig hoofdstuk bevat twee gedeelten; het eerste gedeelte geeft een beschrijving van een aantal strafzaakkenmerken; het tweede gedeelte tracht een antwoord te geven op onze vraagstelling "kunnen we bepaalde faktoren aanwijzen die het verschil in het aantal strafzaken per wedstrijd verk1aren".

We beginnen het hoofdstuk met de operationalisatie van de aard en richting van de overtreding die tot een officielle strafzaak geleid heeft (par. 6.2.); met name het onderscheld in instrumentele en reaktfeve agressie(-aard) staat in deze paragraaf centraal, omdat wij per onafthankelijke variabele hypothesen geformuleerd hebben over de eventuele samenhang met het voorkomen van instrumentele of reaktleve overtredingen.

Daarna worden een aantal andere strafzaakkenmerken besproken; allereerst het tfjdstip van de strafzaak (par. 6.3). Hoewel deze variabele in de verdere analyses niet meer gebrulkt zal worden geeft het nuttige achtergrondinformatie en rechtvaardigt dientengevolge haar beschrijving.

Vervolgens willen we enige aandacht besteden aan het sanktie-aspekt; de belangrijkste kenmerken van de scheidsrechterlijke sanktie (par. 6.4) en van de sanktie van de tuchtkommissie (par. 6.5) komen aan de orde.

In al deze paragrafen is de strafzalk analyse-eenheid. In de door ons geanalyseerde 1750 wedstrijden met strafzaken komen 2664 individuele strafgevalien voor; per wedstrijd een gemiddelde van 1.5 .

Daarna gaan we, in het tweede gedeelte van dit hoofdstuk, nader in op het aantal strafzaken per wedstrijd (par. 6.6). Een ander kenmerk van wedstrijden met strafzaken is immers naast het type strafzaak, het aantal strafzaken per wedstrijd. 
We vragen ons daarbij af of het aantal strafzaken wedstrijden sterk van elkaar doet verschillen. Blijkt dat het aantal strafzaken voor grote verschillen in wedstrijdkenmerken zorgt, dan zou dit voor de verdere behandeling van wedstrijden met strafzaken wellicht een splitsing in analyses naar aantal strafzaken kunnen betekenen.

In paragraaf 6.6 wordt een antwoord gegeven op de vraag of er faktoren zijn aan te wijzen die het verschil in het aantal strafzaken per wedstrijd kunnen verklaren.

over deze probleemstelling zijn overigens geen specifleke hypothesen geformuleerd. We nemen aan dat faktoren die bijdragen aan een grotere kans op strafzaken in een wedstrijd ook belangrijk zullen zijn bij, eventuee1, meerdere strafzaken per wedstrijd.

Dit betekent dat de veronderstellingen per variabele uit overzicht 4.1 ten aanzien van de kans op strafzaken, overgenomen kunnen worden.

\subsection{Aard en richting overtreding*}

In deze paragraaf worden twee strafzaakkenmerken besproken, namelijk de aard (instrumenteel en reaktief) en de richting (ten opzichte van speler of scheidsrechter).

In hoofdstuk $4 \mathrm{zijn}$, voor zowel de aard als de richting van de strafzaak, per onafhankelijke wariabele hypothesen geformuleerd.

Voordat tot toetsing van de veronderstellingen kan worden overgegaan is het noodzakelijk met name de aard van de strafzaak te operationaliseren; operationalisatie van de richting zal weinig interpretatie-problemen opleveren.

In hoofdstuk 2 (par. 2.2 .1 .3 en 2.2 .2 .4 ) is het onderscheid instrumenteel en reaktlef aan de orde gesteld. Daarbif is gebleken dat het onderscheld vaak moeilijk te bepalen is. Alle handelingen $z 1 j n$ in principe instrumenteel. Dat we het onderscheid toch handhaven betekent dat we er vooral een graduele betekenis aan toekennen. Instrumentele agressie in de sportsituatie heeft meer dan de reaktieve agressle een

Zoals vermeld in hoofdstuk 4, par. 4.1, gebrulken we hier het begrip overtreding, daarmee bedoelend overtredingen die tot een officiele strafzalk geworden zijn. 
funktioneel karakter, vooral in het kader van het trachten te behalen wan de winst. Reaktieve agressie bezit de bovengenoemde eigenschappen niet of minder; het gedrag is meer doel op zich en bezit een meer emotioneel karakter.

gestrafte speler:

"Ik werd neergelegd (hard) waarop ik reageer de met een duwtje naar de tegenstander."

gestrafte speler:

"de beslissing wan de scheldsrechter was naar mljm menling onjuist. Ik werd hlerdoor beetje boos en trapte de bal even weg. Daarna kon $i k$ me $\mathrm{mljn}$ naam nlet direkt herinneren, waarna de scheidsrechter mild onm Iddellljk ult het veld stuurde."

gestrafte speler:

"de speler waartegen $1 k$ de overtredling beging kreeg een kans om alleen op onze goal af te gaan warop ik hem aan zljn arm pakte en tegenhleld."

Voordat we overgaan tot operationalisatie van de aard van de strafzaak willen we allereerst nagaan in hoeverre andere onderzoeken dit strafzaakkenmerk opnemen in hun onderzoek. Echter, in tegenstelling tot het groot aantal publikaties die teoretiese bespiegelingen geven over de aard van de overtreding is het onderscheid instrumenteel versus reaktief in onderzoeken nauwelijks terug te vinden. Wel gebruikt men veelvuldig het onderscheid verbaal versus fyslek; een onderscheid dat minder operationalisatieproblemen zal geven. Slechts Begerau (1981) en Schmidt (1978) hanteren het onderscheid in hun onderzoek. Begerau komt tot een verhouding instrumentee1 : reaktief van 5:1; Schmidt konstateert 4 reaktieve overtredingen op 1 instrumentele overtreding; in zijn onderzoek zijn echter ook alle overtredingen (door beoordelaars vastgesteld) ten opzichte van medespelers meegeteld, die bijna allen een reaktief karakter hebben. 
Vermelding van de resultaten van deze twee onderzoeken makt duidelijk dat de verkregen aantallen instrumentele en reaktieve overtredingen in hoge mate beinvloed worden door de definitie en interpretatie van de onderzoeker.

Hoe is onze operationallsatie nu tot stand gekomen?

De operationalisatie van instrumentele en reaktieve agressie kan geschieden aan de hand van het scheidsrechterlijk rapport.

De scheidsrechters hebben bij het invullen van de reden van de strafzaak de beschikking over 32 antwoordkategorieèn (zie bijlage 1.4). We geven allereerst een overzicht van de door de scheidsrechters meest frekwent ingevulde antwoordkategorieën.

Tabe1 6.1.

Reden strafzaak volgens scheidsrechterlijk rapport $(\mathrm{N}=2664)$

- opzettelijk ten val brengen (kategorie 14)

$16 \%$

- aanmerking/opmerking betr. de leiding (kategorie 1) $13 \%$

- herhaaldelijk maken van aan/opmerkingen (kategorie 2) $12 \%$

- trappen (raken) tegenstander (kategorie 17) 9\%

- ruw, onbesulsd, gevaarlijk spel (kategorie 15) $9 \%$

- beledigen scheidsrechter (kategorie 4) $5 \%$

- overige ( 26 kategorieën met $<4 \%$ per kategorie)

Totaa1

$100 \% *$

De antwoordkategorieën zijn vervolgens gesplitst in overtredingen t.o.v. speler of scheldsrechter. In de meeste gevallen levert dit geen problemen op. Echter de kategorleen 27 $t / m 32$ zijn in dit opzicht minder duidelfjk. Zij vormen samen overigens $7 \%$ van het total aantal strafzaken. Bij nadere doorlezing van de strafrapporten hebben we de beslissing hieromtrent alsnog kunnen nemen. De kategorieën 27,28 en 30 worden beschouwd als overtredingen gericht op de tegenspeler en kategorie 29 en 32 als zijnde overtredingen op de scheldsrechter. Kategorie 31 is gezien het kleine aantal ( $N=$ 2) niet in de analyses opgenomen.

* De percentages van alle 32 kategorieern afzonderlijk staan in bijlage 6.1A vermeld. 
De operationalisering van het onderscheld instrumentele en reaktleve agressie levert meer interpretatieproblemen op. Van de overtredingen ten opzichte van de scheidsrechter zijn de kategorteen 1 en 2 (herhaaldelijk) aan-/opmerkingen maken ten opzichte van de leiding als instrumenteel beschouwd. Deze beslissing is bijwoorbeeld niet overeenkomstig de beslissing van Schmidt (1978) in zijn onderzoek; hij beschouwt alle (verbale) agressie ten opzlchte van de scheldsrechter als reaktlef.

Omdat er voor de ons inziens meer reaktieve overtredingen ten opzlchte van de leiding andere kategorleën aanwezig zijn (bijvoorbeeld bemoellijken, beledigen e.d.) hebben we deze beslissing genomen.

Dit betekent dat we de kategorieèn $3 t / m 8,24,26,29$ en 32 als reaktieve overtredingen ten opzichte van de scheidsrechter beschouwen.

Ook bij de overtredingen ten opzichte van de spelers $z$ ijn we ervan uitgegaan dat bepaalde overtredingen meer een funktie in het spel hebben en andere meer een reaktief (emotioneel) karakter. Met nadruk willen we erop wijzen dat het ons hierbłj meer gaat om graduele verschillen en dat bepaalde keuzes diskutabe1 zullen blijven.

Met dit basisprinclpe zijn vervolgens de kategorieën onderverdeeld.

Kategorleen die ons inziens duldelijk het reaktleve karakter van overtredingen weergeven $z i j n$ de kategorieèn $9,10,11$, $13,19 \mathrm{t} / \mathrm{m} 23,28$ en 30 .

De kategorleën 17 en 18 (poging tot) trappen van tegenspeler worden door ons ook als reaktlef beschouwd. Omdat in de strafformulieren voor de gestrafte partij gevraagd wordt naar de omstandigheden die tot de overteding aanleiding hebben gegeven (zle bijlage 1.2 en 1.3 , vraag 2) hebben wij de antwoorden hierop gerelateerd an de twee bovenvermelde kategorleên 17 en 18. Als oorzaak werd met name vermeld "ruw optreden tegenstander" en/of "onjulste beslissing scheidsrechter"; vandaar onze beslissing beide kategorleën als reaktlef te beschouwen.

De kategorleên 12, $14 \mathrm{t} / \mathrm{m} 16,25$ en $27 \mathrm{zl}$ jn ons inzlens meer instrumenteel. Ook deze kategorleën zijn gerelateerd aan de door de gestrafte partij opgegeven oorzaken van het gedrag; een meerderheld van de antwoorden betreft de antwoordkategorie geen bijzondere omstandigheden. Mede gezien het verschil in antwoordpatroon met de door ons benoemde reaktieve over- 
tredingen, hebben we deze 6 kategorieen als eksponenten van instrumentele agressie beschouwd. Met name kategorie 14, het opzettelijk ten val brengen van een tegenstander, wordt door spelers als een rechtvaardige handeling beschouwd in belangrijke wedstrijden (Schmidt, 1978; Pilz, 1982).

Het resultaat van de operationalisatie aard en richting overtreding is ondergebracht in tabel 6.2 .

Tabel 6.2.

Aard en richting overtreding $(N=2664)$

1. Instrumenteel t.o.v. speler

2. instrumenteel t.o.v. scheldsrechter

3. reaktief t.o.v. speler

4. reaktief $t \cdot 0 \cdot v$. scheidsrechter

$60 \%$ van de overtredingen heeft een instrumenteel karakter en $40 \%$ is meer reaktief van aard.

Het is opvallend dat overtredingen ten opzichte van de scheldsrechter $43 \%$ van het totaal aantal strafzaken uitmaken. De onderzoeken van Ekkers en Hoefnagels (1972) en Schmidt (1978) komen tot duidelijk andere cijfers: in beide onderzoeken is het \% bestrafte delikten ten opzichte van de spelleiding $10 \%$.

Wanneer we onderscheid zouden maken in verbale en fysieke overtredingen (respektievelijk $46 \%$ en $54 \%$ ) dan hebben de bestrafte overtredingen ten opzichte van spelers een overwegend fysiek karakter ( $91 \%$ ) en ten opzlichte van scheidsrechter overwegend een verbaal karakter ( $97 \%$ ). Dit resultaat is in overeenstemming met bevindingen van Ekkers en Hoefnagels (1972) en Schmidt (1978); in deze onderzoeken wordt verondersteld dat frustratie veroorzaakt door de scheldsrechter niet zo vlug leldt tot fysiek agressief gedrag van de betrokken speler vanwege het risiko dat hieraan verbonden is.

6.3 .

Tijdstip strafzaak

Zoals in de inleiding is vermeld heeft beschrijving van deze variabele een informatief karakter en zal in de navolgende 
analyse niet gebruikt worden. Bij deze beslissing speelt een rol dat de spelregels ten aanzien van het opleggen van officiele straffen reeds een tijdsdimensie hebben ingebouwd; een offlciele straf wordt o.a. gegeven bij het herhaaldelijk overtreden van de spelregels (officiele waarschuwing) of wanneer de speler zich na een waarschuwlng blifft misdragen (uit het veld sturen). Het zal daarom niet verwonderlijk zijn dat we, naarmate de wedstrijd vordert, meer strafzaken verwachten.

Wanneer we in andere onderzoeken nagaan wat de bevindingen $z i j n$ ten aanzien van het tijdstip van de straf worden deze in hoge mate bepaald door operationalisering van het begrip overtreding of strafzaak.

Albrecht (1982) stelt vast dat $75 \%$ van alle wegzendingen in de tweede helft plaatsvindt; in een ander onderzoek (Albrecht, 1982) treft hij weinig verschil in het aantal avertredingen aan tussen de eerste en tweede helft. In het eerste voorbeeld gat het om scheldsrechterlijke beslissingen, in het tweede voorbeeld bepaalden enkele deskundigen de inhoud van overtredingen.

Gabler (1976) neemt in zijn onderzoek alle door de scheidsrechter waargenomen overtredingen op en treft weinig verschillen aan tussen overtredingen in de eerste en de tweede helft.

In ons onderzoeksmateriaal is de totale speelperiode van 90 minuten onderverdeeld in 6 perioden van één kwartier. (In de bijlage tabel 6.3A zijn de aantallen vermeld.)

Tabe1 6.3 geeft een duidelijk beeld ten aanzien van de tijdsdimensie. Hoe langer de wedstrijd duurt, hoe meer officiele straffen gegeven worden.

In de eerste helft komen $23 \%$ van alle strafzaken voor. In de tweede helft vindt na het eerste kwartier een stijging plaats van het aantal officiële strafzaken. Meer dan $60 \%$ van de strafzaken wordt geregistreerd in het laatste halfuur. 
Tabel 6.3.

Tljdstip van de straf $(N=2.664)$ (aantallen per kwartier)

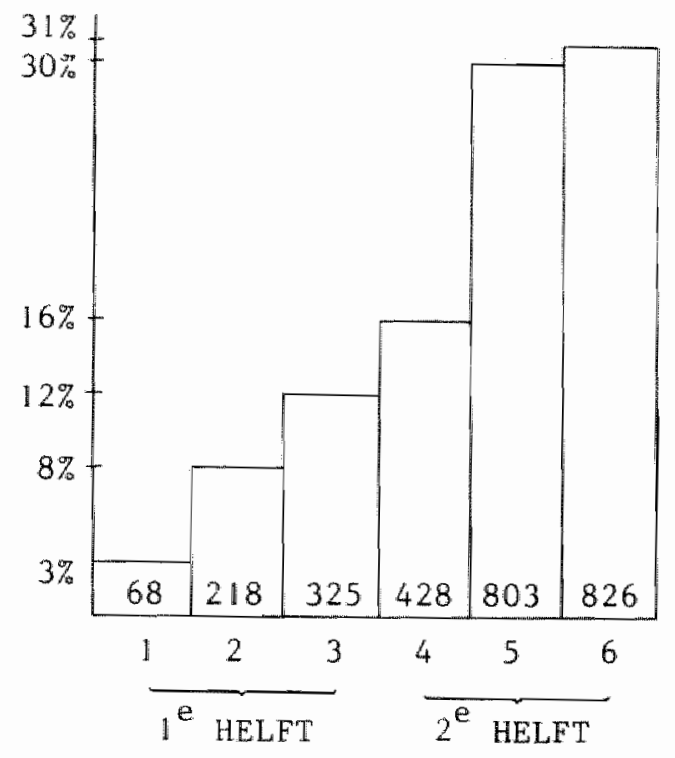

6.4. Scheidsrechterlijke sanktie

In hoofdstuk 1 is aangegeven dat de scheidsrechter, indien hij een overtreding tot officiele strafzaak wil benoemen, twee sankties tot zijn beschikking heeft: de officlële waarschuwing en het uit het veld zenden.

De Handleiding voor de KNVB (1980) maakt duidelijk dat uit het veld zendingen als ernstiger moeten worden opgevat dan offictile waarschuwingen.

Niet alleen wordt bij uit het veld zendingen gesproken over gewelddadige handelingen, $0 . a$. het slaan of trappen van een tegenstander, scheidsrechter of grensrechter, ook het effekt is onmiddellijk, immers de speler wordt van verdere deelname uitgesloten. De uit het veld zending kan volgens Ekkers (1975) als meer effektlef gezien worden: ze heeft direkt invloed op het spelverloop en de overtredende partij wordt gekonfronteerd met een reëel nadeel, namelijk een numerieke minderheid. Hij voegt daaraan toe dat de meeste scheidsrechters definitieve verwijdering van het speelveld een te zware sanktie vinden waardoor zij die weinig toepassen. 
De verhouding tussen aantal warschuwingen en uit het veld zendingen is in de sportliteratuur wel aan bod gekomen maar betreft vooral gegevens uit het betaalde voetbal. Daarbij. gaan straffen vaak gepaard met geldboetes (achteraf) zodat vergelijking met de amateursport moellijk is.

Binnen de betaalde voetbalsektor vinden we grote verschillen. Verschillen die waarschijnlijk gedeeltelijk toegeschreven kunnen worden aan wellicht een ander scheldsrechtersbeleid in verschillende landen. Ook is het mogelijk dat verschillen het gevolg zijn van veranderende instrukties aan scheldsrechters. Instrukties kunnen per jaar en per land verschillen. Albrecht (1982) komt in het Duitse betaald voetbal tot een verhouding van 1 uit het veld zending op 50 waarschuwingen (deze cijfers $z i j n$ gebaseerd op een gemidde1de van 4 seizoenen ( $73 \mathrm{t} / \mathrm{m}$ '76). Volkamer (1971) konstateert in het amateurvoetbal van het totaal aantal officiele strafzaken, $5 \%$ uit het veld zendingen, Ekkers en Hoefnagels (1972) komen uitgaande van de Nederlandse situatie, tot een verhouding van 1 op 4 (uit het veld zending : waarschuwing). Ons materiaal laat het volgende beeld zien:

Tabe1 6.4 .

Ernst van de scheidsrechterlijke straf (N=2664)

Waarschuwingen

Uit het veld zendingen

\section{$\%$}

80

20

$100 \%$

De verhouding 1 uit het veld zending op 4 waarschuwingen wordt ook in ons onderzoek gekonstateerd. Gezien het weinig toepassen van zware sankties willen wij onze veronderstelling uit hoofdstuk 2 (par. 2.4.2.2) herhalen dat een dergelljk sanktlebeleid de kans reèel makt dat spelers overgaan tot instrumentele agressie.

6.5. Sanktie tuchtkommissie

Naast de ernst van de overtreding is medebepalend voor de straf het strafverleden van de betrokken speler. Het straf- 
verleden is aangetekend op de zogenaamde strafkaart (par. 1.3.4).

Reeds is gememoreerd (par.2.4.2.2) dat tuchtrechtelijke sankties voorbeelden zijn van uitgestelde straffen. In het kader van de werking van straffen kan men zich afvragen of een dergelijke uitgestelde straf effektief is. Ekkers en Hoefnagels (1972) geloven dat de funktie van de tuchtkommissie vooral zou moeten bestaan in het oplossen van onzekerheden omtrent feitelijke situaties en het omschrijven van normen die van toepassing zijn op bepalde situaties.

Vergelijking met andere onderzoeken is beperkt ook al omdat In het betaalde voetbal boetes gegeven kunnen worden.

Ekkers en Hoefnagels (1972) konkluderen dat in $10 \%$ van de strafzaken een voorwaardelijke straf wordt opgelegd. Het gemiddeld aantal wedstrijden dat spelers als straf wordt opgelegd is 2.4 .

Tabe1 6.5.

Beslissingen van de tuchtkommissie $(\mathrm{N}=2664)$

seponeren.

berlspen

voorwaardelijke straf

wedstrijdverbod 1 wedstrijd

2 wedstrijden

3 wedstrijden

4 en meer wedstrijden
$\%$

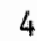

11

23

34

15

106

300

614

893

386

141

224

$100 \%$
----

2664

In $38 \%$ van alle strafzaken (een optelsom van de eerste drle kategorieèn van tabel 6.5) wordt bovenop de beslissing van de scheidsrechter geen ekstra sanktie gelegd. Dit betekent dat de speler in de volgende wedstrijd weer van de partij kan zijn. Wanneer we bij dit percentage optellen het aantal spelers dat éen wedstrijd niet mag spielen dan kunnen we vaststellen dat in bijna driekwart van de gevallen de speler maksimaal één wedstrijd moet missen. 
Samenvattend

Wanneer we onderscheld maken in instrumentele en reaktieve overtredingen blijkt $60 \%$ van de strafzaken meer instrumentee1, $40 \%$ meer reaktief van aard te $z i j n$. Wij hebben overigens duidelijk gemaakt dat de door ons verkregen aantallen instrumentele en reaktleve overtredingen in hoge mate afhankelijk zijn van onze interpretatie van de door de scheidsrechter ingevulde reden van de strafzaak.

Overtredingen ten opzichte van de scheidsrechter (de richting van de strafzaak) maken $43 \%$ van het totaal aantal strafzaken uit.

$60 \%$ van alle strafzaken is afkomstig uit het laatste half uur van de wedstrijd. In een diskriminantanalyse van wedstrljden met 1 strafzaak $(N=1080)$ hebben we wedstrijden waarvan de straf in de eerste helft werd opgelegd, vergeleken met wedstrijden met een strafzaak in de tweede helft van de wedstrifd; de verklaarde variantie bedraagt minder dan $1 \%$ met Eên sllgnifikante varlabele namelijk het doelpuntenverschil. Met name bij wedstrijden met een klein (of geen) doelpuntenversch1l viel de straf in de tweede helft.

Wat de sankties betreft: $80 \%$ van alle strafzaken bestaat uit waarschuwingen; terwijl driekwart van alle straffen die door de tuchtkommissies wordt opgelegd, slechts maksimaal één wedstrijd schorsing oplevert.

Deze laatste twee bevindingen maken in leder geval duidelijk dat nawwelijks gesproken kan worden van een effektieve sanktie (zie ook Ekkers en Hoefnage1s, 1972); immers, het spel én de speler hebben tijdens de wedstrijd geen "last" van de officielle waarschuwing en na de wedstrijd volgt meestal een lichte straf van de tuchtkommissie.

Zoals in par. 2.4.2.2 is besproken is een voorwaarde voor de werking van een straf dat de straf zelf onverenigbaar is met het voordeel van de overtreding. We veronderstellen daarom dat spelers mede overtredingen begaan omdat de ernst van de sanktie over het algemeen licht genoemd kan worden.

Wanneer we de onderlinge samenhangen (pearson-korrelaties) van de vier strafzaakkenmerken bekijken valt met name het verband op tussen de scheidsrechterlijke sanktie en de sanktie van de tuchtkommissie $(.48)$ : waarschuwingen worden in veel gevallen gevolgd door een lichte sanktie van de tucht- 
kommissie; op uit het veld zendingen volgt vaak een zware sanktie.

De overige samenhangen, waarvan er verder niet een boven de .26 uit komt, staan in de bijlage tabel 6.6 vermeld.

6.6. Het aantal strafzaken in een wedstrijd

In deze paragraaf staat de probleemstelling centraal: zijn er faktoren aan te wijzen die het verschil in aantal strafzaken per wedstrijd kumnen verklaren.

Onze veronderstellingen ten aanzien van het aantal strafzaken per wedstrljd zijn, zoals verwoord in hoofdstuk 4 identiek aan onze veronderstellingen over het al dan niet voorkomen van strafzaken.

Met andere woorden, is er bilj een bepalde variabele meer kans op een strafzaak, dan is er ook een grotere kans op meerdere strafzaken.

Voordat we tot beantwoording van bovengenoemde probleemstelling overgaan willen we allereerst ander onderzoek ten aanzien van dit aspekt beschrijven en vergelijken met de bevindingen van ons eigen onderzoeksmateriaal.

\subsubsection{Literatuur}

In de meeste onderzoeken die tot een beschrijving komen van het aantal strafzaken blijft het bij een louter beschrijven. Uiteraard is er een groot verschil tussen het beschrijven van aantallen overtredingen en aantallen strafzaken. De laatste kategorie vormt zoals in de inleiding (par. 1.1) is uitgelegd de top van de 1 jsberg.

Ekkers en Hoefnagels (1972) wier materiaal bestat ult wedstrijden van één selzoen in het betaalde voetbal vermelden alleen de verhouding tussen wedstrijden met strafzaken: $84 \%$ met één strafzaak, $13 \%$ met twee strafzaken en $3 \%$ met 3 of meer strafzaken.

In het Dultse amateurvoetbal is de verhouding van wedstrijden met 1,2 en 3 of meer strafzaken resp. 46,33 en $21 \%$ (Volkamer, 1971). Het felt, dat in zo weinig wedstrijden meerdere strafzaken gegeven worden doet Volkamer konkluderen dat zeer unfaire wedstrijden relatief zelden optreden. Deze konklusie is door een aantal onderzoekers onjuist genoemd 
(o.a. Albrecht, 1982; Bauer, 1972; Begerau, 1981; Pilz, 1979); Immers het aantal strafzaken is geen noodzakelifke indicator voor de "ruwheid" van een wedstrijd.

6.6.2. Onderzoeksresultaten aantal strafzaken in een wedstrijd

We wilen nu overgaan tat presentatie van ons onderzoeksmateriaal.

Tabel 6.7.

Wedstrijden, onderverdeeld naar aantal strafzaken per wedstrijd $(\mathrm{N}=1.750)$

1 straf zaak

2 strafzaken

24

1114

3 strafzaken

9

4 strafzaken

5 strafzaken

6 strafzaken

\begin{tabular}{cr}
3 & 44 \\
1 & 12 \\
0 & 1 \\
\hline $100 \%$ & 1750
\end{tabular}

Resultaten analyse

Een diskriminantanalyse is verricht om de probleemsteling te toetsen. In deze analyse zijn 2 typen wedstrijden met elkaar vergeleken: wedstrijden met 1 strafzaak en wedstrijden met meer dan éen strafzaak.

Omdat er ons inziens geen onderzoeksvariabelen aanwezig zijn die een groot aantal strafzaken per wedstrijd zouden kunnen veroorzaken, hebben wij ten aanzlen van de verklaarde varlantie geen al te hoge verwachtingen, temeer omdat wij alleen maar wedstrijden met strafzaken in de analyse opnemen. De resultaten $z 1 j n$ ondergebracht in tabel 6.8 . 
Tabel 6.8 .

Signifikante variabelen in diskriminantanalyse van

wedstrijden met resp. 1 en $>1$ strafzaak $(N=1750)$

gestand *diskr . funktie

klassenivo

.57

verenigingsgrootte

.43

seizoensverloop

.37

kanoniese korrelatie

$.14(2 \%)$

De analyse levert slechts $2 \%$ verklaarde variantie op.

De werking van de drie signifikante variabelen kan op de volgende wijze worden verwoord: op een hoog klassenivo, bij wedstrijden tussen kleine verenigingen en in het begin van het seizoen komen meer strafzaken per wedstrijd voor.

De variabelen klassenivo en seizoensverloop bleken bij de vergelijking van wedstrijden met en zonder strafzaken reeds een signifikante bijdrage aan het onderscheid te leveren. Dat deze faktoren ook signiflkant zijn indien we het aantal strafzaken per wedstrijd in de analyse opnemen geeft aan dat in de verschillende variabelen die het wedstrijdbelang vertegenwoordigen, er nog dimenstes of specifikatles zijn aan te brengen in meer of minder belangrijke wedstrijden.

Opvallend in de analyse is de signifikantie van de variabele verenigingsgrootte, die meer de sociale kontekst van de wedstrifd weergeeft. Het resultaat bevestigt in ieder geval onze veronderstelling dat voor kleine verenigingen het wedstrijdbelang (het resultaat) groter is dan voor grote verenigingen; tevens geeft het steun aan onze hypothese dat in grotere verenigingen spelers bewust kunnen kiezen voor een lager elftal en dus minder waarde hechten aan prestatie of winst hetgeen resulteert in een kleiner aantal strafzaken per wedstrijd.

We kunnen overigens uit hoofdstuk 6 eén praktiese konklusie trekken: het geringe verschil in wedstrijdkenmerken tussen wedstrijden met 1 en meerdere strafzaken, zal ons geen aanleiding meer geven in de analyses wedstrijden met strafzaken te specificeren naar het aantal strafzaken. 
HOOFDSTUK 7 .

TYPEN WEDSTRIJDEN NAAR AARD EN RICHTING VAN DE OVERTREDING. *

7.1 .

Inlelding

In paragraaf 4.3 (hoofdstuk 4) $\mathrm{zijn}$, voor iedere onderzoeksvariabele afzonderlijk, hypothesen geformuleerd over aard en richting van eventuele overtredingen; dat wil zeggen wanneer verwachten we bij de betreffende variabele een instrumentele of reaktleve overtreding (aard) en worden deze overtredingen begaan ten opzichte van speler of scheidsrechter (richting). Deze veronderstellingen worden in dit hoofdstuk getoetst. omdat onze veronderstellingen op wedstrijdnivo zijn gebaseerd, willen we, voordat tot toetsing wordt overgegaan, eerst nagaan, in hoeverre de verschillende wedstrijden met strafzaken onderverdeeld kunnen worden in een aantal typen wedstrijden. Ieder type wedstrijd wordt dan bepaald door de aard en richting van de overtredingen die daarin voorkomen. Een beschrijving van het door ons gemaakte onderscheid in verschillende wedstrijdtypen is onderwerp van paragraaf 7.2 . Vervolgens willen we leder wedstrijdtype afzonderlijk vergelijken met een (evengroot) aantal wedstrijden zonder strafzaken via diskriminantanalyses. Bij deze analyses is het echter te verwachten dat de variabelen scheidsrechter en klassenivo die een belangrijke rol hebben gespeeld bij een vergelijking wan wedstrijden met en zonder strafzaken ook in deze analyses belangr $1 j k$ zullen blijken te zijn zodat informatie uit deze analyses weinig mér informatie zal bevatten. Daarom is besloten allereerst de variabelen status scheidsrechter en klassenivo te relateren aan de door ons gekonstrueerde wedstrijdtypen en daarna diskriminantanalyses te verrichten zonder de zofuist genoemde variabelen.

Een en ander zal in de inleiding van paragraaf 7.3 mader worden uitgelegd.

Het leek ons overigens zinvol ons daarna af te vragen wat de gevolgen van de verschtllende overtredingen voor de spelers

De term overtreding heeft betrekking op die overtredingen die door de scheidsrechter als zodanig ernstig zijn beschouwd dat zij tot officiéle strafzaak benoemd zijn. 
zijn. Welke straffen kunnen zij respektievelijk van scheidsrechter en tuchtkommissie verwachten. De veronderstellingen over de sankties die we in hoofdstuk 4 geformuleerd hebben kunnen derhalve hier getoetst worden. Wij willen nogmaals aksentueren dat kennis van het sanktiebeleid ons antwoord kan verschaffen op de vraag of en in hoeverre sankties effektief $z i j n$. Zijn zij zodanig zwaar dat de speler er duidelijke nadelen van ondervindt, of blijken de voordelen van de overtreding groter dan de nadelen van de straf. In het laatste geval is, zoals in hoofdstuk 2 beschreven, met name instrumentele agressie te verwachten.

De vraag is echter op welk nivo we de sankties moeten beschrijven, op het wedstrijd- of strafzaaknivo. Paragraaf 7.4 zal duidelijk maken en verantwoorden waarom wij bij de beantwoording van de sankties voor de strafzaak als analyseeenheid gekozen hebben.

7.2 .

Typen wedstrijden naar aard en richting overtreding

We hebben $n_{*}$ nagegaan in hoeverre wedstrijden met strafzaken $(N=1738)$ onderverdeeld kunnen worden in verschillende typen wedstrijden, waarbij de aard en richting van de overtreding als grondslag voor de verdeling diende (tabel 7.1). $B 1 j$ de typen $1,2,4$ en 5 komt grotendeels 1 strafzaak voor respektievelijk 79, 89,80 en $90 \%$; in de wedstrijdtypen 3,6 en 7 worden minstens 2 strafzaken gegeven.

Gezien de aantallen van de diverse wedstrijden kan gekonkludeerd worden dat $76 \%$ van de wedstrijden (typen $1,2,4$ en 5) wordt gekarakteriseerd door de 4 typen die resultaat zijn geweest van onze operationalisatie in aard en richting straf zaak (tabe1 6.2 , hoofdstuk 6 ).

* Van 12 wedstrijden zijn weliswaar strafrapporten opgemaakt; deze rapporten hebben betrekking op gestaakte wedstrijden, zonder dat een speler een offlciele straf is opgelegd. Deze wedstrijden zijn daarom niet in de analyses betrokken. 
Tabe1 7.1 .

Type wedstrijden naar aard (instrumenteel of reaktief) en richting (speler of scheidsrechter) overtreding $(\mathrm{N}=1750)$

aard/richting overtreding

1. Instrumentee1/speler

2. instrumenteel/scheidsrechter

3. instrumenteel sp. en scheidsr.

4. reaktief/speler

5. reaktief/scheidsrechter

6. reaktlef speler en scheidsr.

7. Instrumenteel én reaktief

totaal

7.3. Samenhang tussen de onafhankelijke variabelen enerzijds en de wedstrijdtypen anderzijds.

In de inlelding (par. 7.1) is opgemerkt dat, indien we nagaan in hoeverre elk wedstrijdtype op een aantal van onze onafhankelijke variabelen afwijkt van wedstrijden zonder strafzaak, het te voorzien is dat bij deze vergelijking de variabelen status scheidsrechter en klassenivo een belangrifk diskriminerend vermogen zullen bezltten; te voorzien ondat bij een vergelijking van wedstrijden met en zonder strafzaken deze twee variabelen bij uitstek bleken te "diskrimineren" (hfdst. 5).

Bij toepassing van zeven diskriminantanalyses, ieder wedstrijdtype is vergeleken met een ongeveer even groot aantal wedstrifden zonder strafzaak, bleek onze verwachting juist: in alle analyses zorgen of wel de status scheldsrechter en/of het klassenivo, gezien het gewicht van de gestandaardiseerde diskrimfnant funktlekoefficlent voor het grootste aandeel in de totaal verklaarde variantle.

Daarom hebben we besloten allereerst een beschrijving te geven van de variabelen status scheidsrechter en klassenivo en hun samenhang met de zeven wedstrijdtypen (par. 7.3.1). Daarna (par. 7.3.2) worden via diskriminantanalyse de andere onafhankelijke variabelen gerelateerd aan de wedstrijdtypen. Daardoor wordt een beter inzicht verkregen in de werking van deze variabelen dat wil zeggen voor welke percentages ver- 
klaarde variantie zorgen $z i j$, zonder dat de variabelen status scheidsrechter en klassenivo in de analyse worden opgenomen.

\subsubsection{Status scheidsrechter en klassenivo.}

Bij de beschrijving van de variabelen status scheidsrechter en klassenivo hebben wij allereerst de beslissing genomen deze variabelen op een andere wijze te presenteren. Daarbij is gekozen voor een driedeling: officièle scheidsrechters die respektievelijk wedstrijden leiden in de le en $2 \mathrm{e}$ klasse, en $3 e$ en $4 \mathrm{e}$ klasse, en tenslotte, niet-officlële scheidsrechters.

Door deze driedeling wordt allereerst een vergelijking mogelijk tussen het scheidsrechtersbeleld van de officielen; tevens kunnen op hetzelfde $3 \mathrm{e}$ en $4 \mathrm{e}$ klassenivo officielle en niet-officielle scheidsrechters met elkaar worden vergeleken. ondat we in dit gedeelte onze veronderstellingen uit overzlcht 4.1 willen toetsen willen wij deze hier kort memoreren: officièle scheidsrechters zullen meer instrumentele overtredingen tot strafzaak maken; niet-officielen relatief gezien (niet absoluut) meer reaktieve overtredingen. Wat de variabele klassenivo betreft, op een hoog klassenivo verwachten we meer instrumentele overtredingen.

Bij de presentatie van de gegevens hebben we gebruik gemaakt van het begrip incidentie. In deze paragraaf betekent dit het aantal strafzaken gedeeld door het aantal wedstrijden, vermenigvuldigd met honderd. Deze vermenigvuldiging is vooral om presentatieredenen geschied; niet-officiële scheidsrechters melden in een zo geringe mate strafzaken, dat weergave van deze aantallen uitsluitend cijfers achter de komma zouden opleveren.

Allereerst geven we in tabel $7.2 \mathrm{~A}$ aan de participatie van de drie scheidsrechterskategorieën in wedstrijden met strafzaak en in het totale wedstrijdenbestand; tabe1 $7.2 \mathrm{~B}$ vermeldt de incidentie van strafzaken naar wedstrijdtype voor ledere scheidsrechterskategorie afzonderlijk. 
Tabe1 $7.2 A$.

Participatie drie scheidsrechterskategorieën in wedstrijden met strafzaak en in totale wedstrijdenbestand $(N=12.389)$

scheidsrechterskategorieên officielen niet-off. $1 / 2$ klasse $3 / 4$ klasse

totaal

- \% wedstr met strafz.

$24 \%$

$15 \%$

$3 \%$

$14 \%$

- gem. aantal strafzaken per wedstrijd

1.59

1.44

1.39

1.53

- totaal aantal geleide wedstr.

Tabe1 7.2.B.

Incidentie van strafzaken* naar wedstrijdtype per scheidsrechterskategorle

scheidsrechterskategorieèn officiëlen niet-off.

$1 / 2$ klasse $3 / 4 \mathrm{klasse}$

totaal

1. Instr./speler

2. Instr./scheidsr.

3. Instr. sp.en scheidsr.

4. reaktief/speler

5. reaktlef/scheidsr.

6. reakt. sp.en scheldsr. 1

7. Instr. én reaktief

totaal (incidentie)
10

5

2

4

3

13

38
3

5

1

4

2

0,4

6

21,4
0,3

1

$-$

0,9

0,6

0,1

1,4

4,3
4

3

1

3

2

0,6

7

20,6

* Incidentie strafzaken: $\frac{\text { aantal strafzaken }}{\text { aantal wedstrijden }} 100$

Tabel 7.2A maakt nogmaals het grote verschil duidelijk tussen het aanhangig maken van strafzaken door officiëlen en niet-officlelen.

Voor de 3 scheldsrechterskategorieen (beginnend met de officielen in de eerste en tweede klasse) is het \% wedstrijden met strafzaken, te karakteriseren als de wedstrijd incidentie, respektievelijk 24,15 en $3 \%$. 
Wanneer we de incidentiecijfers van de drie scheidsrechterskategorieën nader bezien (tabel 7.2B) willen wij benadrukken dat het hier gaat om de bespreking van relatieve verschillen; in absolute aantallen ligt het incidentiecijfer voor met name de niet-officielen in alle wedstrijdtypen beduidend lager vergeleken met de incidentiecijfers van de officielen. Allereerst willen wij nagaan wat de overeenkomsten in incidentie tussen de scheidsrechterskategorieën $z i j n$ om daarna een aantal verschillen te bespreken.

hanneer we per scheidsrechterskategorie nagaan welke wedstrijdtypen voor hoge en welke voor lage incidentiecijfers zorgen, blijkt voor alle drie kategorieën wedstrijdtype 7 het hoogste incidentiecijfer te bezitten en de wedstrijdtypen 3 en 6 het laagste. Dit betekent dat scheidsrechters relatief vaak in éên wedstrijd instrumentele én reaktieve overtredingen bestraffen, maar nauwelijks in één wedstrijd zowel overtredingen ten opzichte van spelers als ten opzichte van scheidsrechters bestraffen.

Teoreties gezien is met name wedstrijdtype 7 moeilijk te interpreteren; wij hebben immers alleen veronderstellingen geformuleerd over ofwel de kans op instrumentele danwel reaktieve overtredingen.

Wanneer we de verschillen in incidentie voor de wedstrijdtypen 1, 2, 4 en 5 bezien is het opvallend dat, binnen de twee officiele scheidsrechterskategorieën, officlelen in de eerste en tweede klasse relatief vaak instrumentele overtredingen ten opzichte van spelers bestraffen. Voor dit verschil zijn twee mogelijke oorzaken aan te geven; de eerste oorzaak is gerelateerd aan het gedrag van spelers en de tweede oorzaak wordt beargumenteerd vanuit de scheidsrechterspositie: Spelers op een hoog klassenfvo zullen eerder overwegen instrumentele overtredingen te begaan; het wedstrijdbelang is in deze klassen hoger en in deze klassen hebben $z i j$ wellicht ervaring opgedaan met het al dan niet opgelegd krijgen van straffen.

Een andere oorzaak is, eveneens in overeenstemming met de door ons geufte veronderstelling: officiele scheidsrechters rapporteren meer instrumentele overtredingen omdat het konstateren én beslissen in spelsituaties met dit soort overtredingen ervaring in het leiden van wedstrijden vereist. Een ervaring die de officielle scheidsrechters in de derde en vierde klasse meestal missen omdat officlele scheidsrechters hun "loopbaan" beginnen op het laagste klassenivo. 
Overigens moet aan deze konstatering volledigheidshalve worden toegevoegd, dat officiêle scheldsrechters ook op het laagste nivo fluiten omdat ze of de kwaliteit missen "hogerop wedstrijden te leiden of, na een aantal jaren scheidsrechter te zijn geweest vrijwillig terugkeren naar een lager nivo.

Het is opvallend dat het strafbeleid van de officièle scheidsrechters in de derde en vierde klasse wat de aard en richting van de overtredingen betreft, veel gelijkenis vertoont met het strafbeleid van de niet-offlicielen.

Befde kategorieën scheidsrechters rapporteren verhoudingsgewijs veel instrumentele overtredingen ten opzichte van hun leiderspositie. Men zou hieruit de konklusie kunnen trekken dat de beperkte ervaring deze officièlen en niet-officiëlen ertoe brengt al gauw een beroep te doen op hun gezagspositie in het veld. Een dergelijk scheidsrechtersbeleid zou men kunnen interpreteren als een feitelijk dan wel gepercipieerd gebrek aan gezag (van Galen en Diederiks, 1984).

Het relatief grote aandeel van de reaktieve overtredingen kan de neerslag zijn van het feitelijk gedrag van spelers in derde en vierde klasse. Het is vooralsnog onduidelijk waarom spelers juist in deze klassen reaktieve agressie vertonen. Wolf (1962) suggereert dat spelers op een laag nivo door een gebrek aan techniek, kompensatie zoeken in "een tomeloze inzet" met alle gevolgen vandien.

Men kan ook veronderstellen dat het minder belangrijk zijn van wedstrijden op een laag klassenivo betekent dat, $\mathrm{a}$ is spelers zich agressief gaan gedragen zij dit meer op emotionele gronden doen, zonder daarbij direkt het winstbelang in acht te nemen.

\subsubsection{Overige onafhanke11 jke variabelen}

$\mathrm{Na}$ behandeling van de variabelen status scheidsrechter en klassenivo willen wij nu nagaan of de veronderstellingen julst zljn die we voor de overige onafhankelijke variabelen geformuleerd hebben ten aanzien van de aard en richting van de overtreding. Met de onafhankelijke variabelen bedoelen we die variabelen die ook bij de vergelijking tussen wedstrijden met en zonder strafzaken zijn gebruikt.

Toetsing vindt plaats met behulp van diskriminantanalyse: leder wedstrijdtype hebben we vergeleken met een aantal wed- 
strijden zonder strafzaak. Via een a-selekte steekproef* 21 jn de wedstrijden zonder strafzaak verdeeld in 7 elkat uitsluitende eenheden; ieder part is (ongeveer) gelijk aan de 7 vormen van de typologie. De resultaten van de analyses zijn weergegeven in de tabellen 7.3 en 7.4 (bijlage 7.1 geeft meer gedetailleerde informatie).

In tabel 7.3 worden de veronderstellingen en resultaten over wedstrijdtypen met instrumentele overtredingen weergegeven; tabel 7.4 geeft aan in hoeverre onze hypothesen omtrent wedstrijdtypen met vooral reaktieve overtredingen worden bevestigd. In deze laatste tabel is ook het wedstrijdtype opgenomen warin zowel instrumentele als reaktieve overtredingen worden bestraft.

In de linkerkolom van de tabellen wordt door een + teken aangegeven of we bij de desbetreffende een hypothese geformuleerd hebben over de specifieke aard en of richting van de overtreding; de rechterkolom bevat een weergave van de resultaten.

Een o teken geeft aan dat hoewel een hypothese is gesteld de desbetreffende variabele geen signiflkant diskriminerend vermogen bezit; terwij1 een () teken inhoudt, dat, hoewel geen hypothese is gesteld, de varlabele signifikant lis. Gezien het uitsluiten in de analyses van de variabelen status scheldsrechter en klassenivo en de resultaten van de analyses kennende waarin juist deze varlabelen voor een groot deel van de verklaarde variantie verantwoordelijk zijn, hebben we geen al te hoge verwachtingen van het percentage verklaarde variantle in de komende analyses.

* de a-selekte steekproef uit wedstrijden zonder strafzaak $(N=1750)$-overigens zijn dit dezelfde wedstrijden als gebruikt in hoofdstuk 5 en 6- is getrokken via het (aselekt) kriterium, afstand tussen de velden; met name de cijfers achter de komma (meters in dit geval) hebben als willekeurige verdeelsleutels gefungeerd. 
7.3.2.1. Toetsing hypothesen instrumentele overtredingen

Tabe1 7.3.

Hypothesen en resultaten over het voorkomen van instrumentele overtredingen (wedstrijdtypen $1 \mathrm{t} / \mathrm{m} 3$ )

hypothese

(1)

instr.instr . instr. /sp. /sch. /sp. + recht.sch.r. einde seizoen

klein rangverschil afstand

ger $\mathbb{n g}$ aantal doelp. klein doelverschil winst/verlies

kleine ver.grootte stad

$\%$ verklaarde variantie
$+*++$ $+\quad+$ geen hypothese geformuleerd

$+\quad+$

$+t+$

geen hypothese geformuleerd hypothese bevestigd?

(1)

(2)

* wedstrijdtypen met allén instrumentele overtredingen ** + teken houdt in dat bij deze variabele een hypothese is gesteld; de verwachte richting ervan wordt bij de desbetreffende variabele aangegeven.

*** 0 teken houdt in dat de variabele in de diskriminantanalyse geen signifikant diskriminerend vermogen bezit, hoewel een hypothese is gesteld;

****() teken houdt in dat over deze variabele geen hypothese is geformuleerd echter in de diskriminantanalyse een signifikant diskriminerend vermogen blijkt te bezitten.

In het algemeen ligt het percentage verklaarde variantie hoger bij wedstrijden met instrumentele overtredingen waarin in leder geval een speler "slachtoffer" is (typen 1 en 3 ). Het percentage bij wedstrijdtype 3 is overigens minder betrouwbaar door het kleine aantal wedstrijden van dit wedstrijdtype $(\mathrm{N}=61)$ (zie ook bijlage 7.1). 
Van de 18 gestelde hypothesen, worden er 5 bevestigd. Twee hypothesen, betrekking hebbende op het seizoensverloop, worden niet bevestigd. Il veronderstellingen blijken in de analyses geen signifikant diskriminerend vermogen te bezitten. Eén resultaat wordt verkregen waarover geen specifieke bypothese is gesteld.

Indien we de signifikante diskriminerende variabelen bekijken, blijken vooral de variabelen die het wedstrijdverloop weergeven belangrijk; met name de variabelen doelpuntenverschill en aantal doelpunten. De variabele doelpuntenverschil is in alle analyses signifikant en zorgt voor het grootste aandeel in de verklaarde variantie.

De werking van deze variabele geeft aan, dat bij een klein doelpuntenverschil vooral instrumentele overtredingen ten opzichte van spelers en/of scheidsrechter voorkomen; door een klein doelpuntenverschil is de wedstrijd van bijzonder belang geworden; de spelers zullen daardoor niet alleen door middel van instrumentele overtredingen tegen spelers, maar ook ten opzichte van de scheidsrechter trachten het spelverloop te betnvloeden. Deze resultaten $z 1$ jn konform onze hypothese.

Wat de signifikantie van de variabele winst/verlies betreft, instrumentele overtredingen ten opzichte van spelers komen vooral voor indien de uitspelende vereniging wint (of de thuisspelende vereniging verliest). Omdat we in dit hoofdstuk de wedstrijd als analyse-eenheld hanteren, is het niet mogelijk, zoals uitgelegd in hoofdstuk 1 , par. 1.5, het thuis - uitspelen als onafhankelijke variabele in de analyse op te nemen.

De variabele wedstrijdzondag die minder het wedstrijdverloop maar meer het wedstrijdbelang vooraf weergeeft is signifikant bij de wedstrijdtypen 1 en 3 .

De werking van het seizoensverloop is tegengesteld aan onze hypothese: niet aan het einde maar juist aan het begin van het seizoen worden meer instrumentele overtredingen begaan.

Een aantal veronderstellingen $z i j n$ hierbij mogelijk.

De veelheid van instrumentele overtredingen an het begin van het selizoen kan een feitelijke weerspiegeling zijn van het algemeen belang van de wedstrijden voor alle teams; er is immers nog niets beslist en voor leder elftal is "winnen" nog uiterst belangrijk.

Een andere verklaring is dat spelers én scheldsrechters e1kaars positie testen.

Spelers proberen na te gaan welke gedragingen bestraft worden; scheidsrechters zullen trachten, vooral in het begin 
van het seizoen, een scheidsrechtersbeleid voor het verdere sefzoen neer te zetten; dit betekent een stringent toepassen van de spelregels en een grotere kans op het bestraffen van overtredingen.

\subsubsection{Toetsing hypothesen reaktieve overtredingen}

Tabe1 7.4.

Hypothesen en resultaten over voorkomen van voornamelijk reakt leve overtredingen

$$
\begin{aligned}
& \text { hypothese } \\
& \text { wedstrijdtype } \\
& \text { (4)* (5) (6) (7) } \\
& \text { re- re- re- in- } \\
& \text { akt/ akt/ akt. str. } \\
& \text { sp. sch-sp. en } \\
& \text { re. en re- } \\
& \text { sch. akt. }
\end{aligned}
$$

\begin{tabular}{|c|c|c|c|c|c|c|c|}
\hline rangverschi1 & $\begin{array}{l}\text { geen } \\
\text { gefo } \\
\text { geen } \\
\text { gefo }\end{array}$ & $\begin{array}{l}\text { hy } \\
\text { rmu } \\
\text { by } \\
\text { cmu }\end{array}$ & $\begin{array}{l}\text { these } \\
\text { erd } \\
\text { these } \\
\text { erd }\end{array}$ & & & & \\
\hline kleline afstand & $+* *$ & + & + & $0 * \star \star$ & ja & 0 & \\
\hline gering aant. doelp. & + & + & + & 0 & 0 & 0 & \\
\hline klein doelp.versch & + & + & + & 0 & 0 & 0 & ()$* * * *$ \\
\hline $\begin{array}{l}\text { verlies (ultklub) } \\
\text { ver.grootte }\end{array}$ & geen & $\begin{array}{l}+ \\
\text { hy }\end{array}$ & these & 0 & ja & 0 & \\
\hline stad & $\begin{array}{l}\text { gefor } \\
+\end{array}$ & + & $\begin{array}{l}\text { erd } \\
+\end{array}$ & ja & 0 & 0 & $\begin{array}{l}()^{* * * *} \\
j a\end{array}$ \\
\hline \% verklaarde variat & atie & & & $1.7 \%$ & $2.5 \%$ & $8 \%$ & $6 \%$ \\
\hline
\end{tabular}

* nummerlng van de wedstrijjdypen korrespondeert met nummering uft tabel 7.1.

** + teken: bij deze variabele is hypothese gesteld; de verwachte richting ervan wordt bif de desbetreffende variabele aangegeven.

*** 0 teken: de varlabele bezit in de diskriminantanalyse geen signifikant diskrimfnerend vermogen, hoewel hypothese is gesteld.

****()teken: variabele is in diskriminantanalyse signifikant, echter geen hypothese gesteld. 
Tabe1 7.4 geeft een overzicht van hypothesen en resultaten omtrent het voorkomen van reaktieve overtredingen en van het wedstrijdtype waarin instrumentele en reaktieve overtredingen voorkomen (zie bijlage 7.1).

Als we allereerst ons beperken tot de wedstrijdtypen met alléen reaktieve overtredingen, blijken van de 15 geformuleerde hypothesen er drle door de resultaten te worden bevestigd. De variabelen waarop de overige veronderstellingen zijn gebaseerd, blijken in de analyses niet signifikant te zijn.

Een mogelijke verklaring voor deze resultaten is, dat reaktieve overtredingen, door hun veelal emotionele aard en het niet funktioneel zijn in het spe1, moellifk te voorspellen zijn. Deze overtredingen worden wellicht veroorzaakt door een aantal incidentele situaties, warin het niet makkelijk valt een strukturele, dus voor ons voorspelbare komponent te ontdekken.

Van de variabelen die het wedstrijdbelang vertegenwoordigen blijkt alleen de afstand in één analyse signifikant. Bijeen kleine afstand komen meer reaktieve overtredingen ten opzlchte van de scheidsrechter voor (konform onze hypothese). Onze hypothese dat bij een kleine afstand ook meer reaktieve overtredingen ten opzichte van spelers plaatsvinden wordt door de resultaten niet bevestigd. Een aantal verklaringen zijn hierbij mogelijk.

De scheidsrechter kan door beide partijen als een buitenstaander gezien worden; wellicht dat daardoor de eventuele emotie in de richting van het andere elftal wordt verplaatst naar de scheidsrechter. Het is ook mogelijk dat de scheidsrechter zich eerder outsider voelt en gedragingen van spelers als gezagsondermijnend beoordeelt; immers, een kleine afstand makt het warschijnlijk dat spelers elkaar goed kennen.

Van de variabelen die het wedstrijdverloop vertegenwoordigen is één varlabele in één analyse signifikant: wedstrijden met reaktieve overtredingen tegen de scheidsrechters komen voor in wedstrijden waarin meer dan gemiddeld door de uitklub wordt verloren. Ook op dit aspekt gaan we in hoofdstuk 8 nader in.

In de stad komen meer reaktieve overtredingen ten opzlchte van spelers voor. Onze globale veronderstelling dat hleraan een kosmopolitiese oriëntatie van de stedeling ten grondslag $11 \mathrm{gt}$, zich uitend in een ruimere interpretatie van de spel- 
regels en derhalve een grotere kans op strafzaken wordt daardoor bevestigd; een bevestiging die nog ekstra voeding krijgt omdat in de stad meer wedstrijden voorkomen met zowel instrumentele als reaktieve overtredingen (wedstrijdtype 7). Dit type wedstrijd komt overigens ook voor bij wedstrijden met gemiddeld een klein doelpuntenverschil en wedstrijden tussen kleine verenigingen; een klein doelpuntenverschil kan betekenen dat spelers alle mogelijke middelen gebruiken on de winst te bereiken.

Wat de variabele verenfigingsgrootte betreft hebben we verondersteld dat mede gezien de naam van de vereniging, kleine verenigingen meer instrumentele overtredingen zullen veroorzaken. Blijkbaar is echter het belang van de wedstrijd voor kleine verenigingen dermate groot dat $z i j$ ook reaktieve overtredingen begaan.

Wat in het begin van dit hoofdstuk is opgemerkt, maar niet in cijfers tot uitdrukking is gekomen is de belangrijkheid van de varlabelen status scheidsrechter en klassenivo indien we ze in de diskriminantanalyses van de zeven wedstrijdtypen hadden ingebracht. De verklaarde variantie, mét deze variabelen is, lopend van wedstrijdtype $1 \mathrm{t} / \mathrm{m} 7 \mathrm{resp} .30 \%, 12 \%$, $25 \%, 14 \%, 8 \%, 24 \%$ en $23 \%$.

Gezien de resultaten van de analyses, zonder de variabelen scheidsrechter en klassenivo moet de konklusie luiden dat het diskriminerend vermogen van de andere onderzoeksvariabelen gering is, gelet op het percentage verklaarde variantie en het aantal signifikante variabelen.

Dit betekent dat de meeste van onze onderzoeksvariabelen matige voorspellers zijn voor het voorkomen van instrumentele en/of reaktieve overtredingen.

7.4. Sankties scheidsrechter en tuchtkommissie.

7.4.1. Inleiding

In deze paragraaf willen wij nagaan welke gevolgen strafzaken voor de betrokken spelers hebben. Wat zijn de gevolgen in en na de wedstrijd, met andere woorden welke sanktie kunnen $z i j$ respektievelijk van scheidsrechter en tuchtkommissie verwachten.

We nemen aan, gezien onze interpretatie van de aard van de strafzaak dat instrumentele overtredingen lichter zulien worden bestraft dan reaktieve overtredingen. 
Gezien de resultaten van par. 7.2 , officile scheidsrechters met name in de eerste en tweede klasse bestraffen meer instrumentele overtredingen, verwachten wij ook van hen dat zij de waarschuwing als sanktie zullen hanteren; niet-officiellen zullen, relatlef gezlen, meer de sanktie uit het veld zenden, toepassen.

Ten aanzien van de sankties van de tuchtkommissie is door ons verondersteld (hfdst. 4, par. 4.4) dat ook door de tuchtkommissie reaktieve overtredingen zwaarder zullen worden bestraft; met betrekking tot de richting van de strafzaak zullen zij met name overtredingen tegen de scheldsrechter (de gezagsdrager) als ernstig beschouwen en dienovereenkomstig bestraffen.

overigens is in hoofdstuk 6 de samenhang vermeld tussen de sanktie van de scheidsrechter en die van de tuchtkommissie. Wij willen nu een aantal aspekten aan de orde stellen die te maken hebben met de beschouwing en presentatie van de sankties.

Een beslissing die bij de beschrijving genomen moet worden is, welk analysenivo we ter hand zullen nemen, namelijk het wedstrijd- of strafzaaknivo.

Voor de konsistentie van ons gehele verslag zou het aanbeveling verdienen ook hier de wedstrijd als analyse-eenheld te beschouwen en bijvoorbeeld de in par. 7.2 gehanteerde wedstrijdtypen te gebruiken.

Echter wanneer we sankties op wedstrijdnivo willen beschrijven, dan zou hieraan de verondersteling ten grondslag liggen dat we een samenhang verwachten tussen sanktie en wedstrijdtype.

Het wedstrijdtype is echter een teoretiese konstruktie van de onderzoeker: zoals we aangetoond hebben (hfdst. 6, par. $6.2)$ is het onderscheld instrumentee1/reaktief in hoge mate afhankelijk van onze elgen interpretatle ervan.

We kunnen ons voorstellen dat een scheidsrechter bij een tweede of volgende officielle sanktie $z i j n$ beslissing inzake de eerste strafzaak in overweging neemt. In alle wedstrijden waarin echter slechts één strafzaak voorkomt $63 \%$ van alle wedstrijden met strafzaken is bovenstaande redenering nlet toe te passen.

Bovenstaande in overweging nemend hebben we aldus besloten de strafzaak als analyse-eenheid te hanteren. 
Zowel bij de beschrifving van de scheidsrechterlijke- als van de tuchtrechtelijke sanktie willen we drie scheidsrechterskategorieën hanteren, zoals we die in par. 7.2 gedefinieerd en gebruikt hebben. Deze indeling heeft, in vergelijking met het globale onderscheid officlele versus niet-offlclele scheidsrechters, een aantal yoordelen; het eerste voordeel is dat een meer gedifferentieerd beeld van het scheldsrechtersbeleld wordt verkregen; een tweede voordeel is dat daardoor het onderscheld naar klassenivo intakt blijft.

7.4.2. Scheidsrechterlijke sankties per scheidsrechterskategorie

Zoals in hoofdstuk 1 en hoofdstuk 6 is vermeld, heeft de scheidsrechter, indien hij een overtreding tot officielle strafzaak wenst te maken, twee sankties tot zijn beschikking de waarschuwing en het uit het veld sturen. Par. 6.4 heeft aangetoond dat hoewel het uit het veld sturen als meer effektief kan worden gezlen, het heeft direkt invloed op het spelverloop, deze sanktie relatief weinig wordt toegepast, name11jk in $20 \%$ van de strafzaken.

Tabel 7.5A geeft per scheidsrechterskategorie de incidentie van het uit het veldzenden, dat wil zeggen het aantal uit het veld gestuurden gedeeld door het aantal wedstrijden, vermenigvuldigd met honderd.

Vervolgens wordt in tabe1 7.5B, voor ieder type strafzaak het percentage uit het veld zendingen vermeld; trekt men dit percentage af van $100 \%$ dan krijgt men per strafzaak en scheidsrechterskategorie het percentage waarschuwingen.

Tabe1 $7.5 \mathrm{~A}$

Incidentle uit het veldzendingen per scheidsrechterskategorie

Incldentie

scheidsrechterskategorie offlciëlen

niet-off. total

uit het veld-

zendingen

(incidentie -

totaa1)

$1 / 2 \mathrm{klasse} 3 / 4 \mathrm{klasse}$

$$
\begin{array}{llll}
5.5 & 4.8 & 2.3 & 4.3
\end{array}
$$

(38)

(21)

$(4 \cdot 3)$

*

incidentie ult het veldz. $\frac{\text { aantal uit het veldz* }}{\text { aantal wedstrijden }} \times 100$ 
Tabe1 $7.5 \mathrm{~B}$

Percentage uit het veldzendingen per type strafzaak naar scheidsrechterskategorie $(\mathrm{N}=537)$

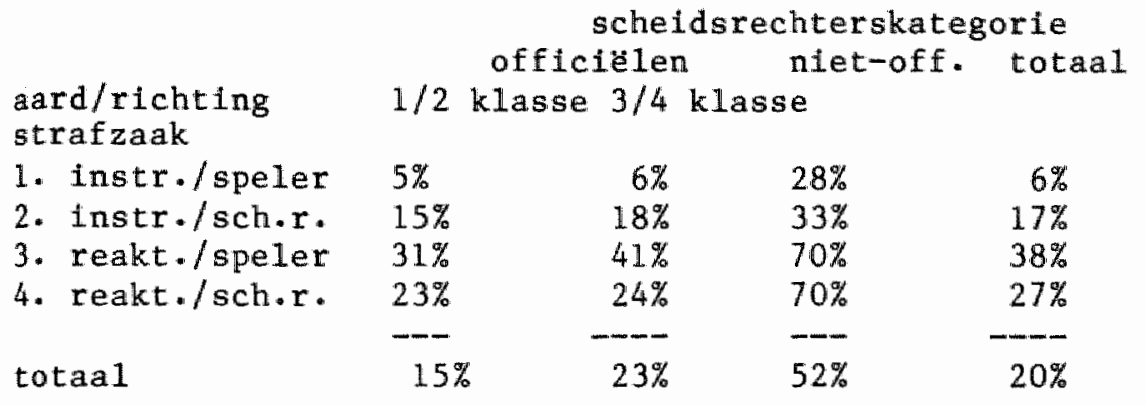

Wanneer we de incidentie van uit het veldzendingen per scheidsrechterskategorie met elkaar vergelijken blijkt het grote verschil tussen de officiële scheidsrechters enerzijds en de niet-officiëlen anderzijds.

De officiëlen, op alle klassenivo"s, hanteren vooral de waarschuwing als sanktie; de niet-offictelen, er rekening mee houdend dat het aantal ver achter blijft bij de aantallen van de officielen, gebruiken vooral de sanktie uit het veld sturen.

Het strenge optreden van de niet-officiëlen wordt niet verklaard door het klassentvo omdat officielen in de derde en vierde klasse overwegend "waarschuwen".

Een veronderstelling voor de hier gevonden verschillen in sanktietoepassing zou gelegen kunnen zijn in het al dan niet ervaring hebben met het leiden van wedstrijden. officiedien zullen niet wachten tot spelers ernstige overtredingen begaan, maar hen, via relatief lichte sankties, tot voorzichtigheld in het spel manen.

De niet-officielen zullen dan pas overgaan tot het toepassen van sankties indien de overtreding dermate ernstig is, dat de beslissing tot een strafzaak boven eventuele kritiek uitgaat.

In dit verband is het zinvol op te merken dat Mark et al (1983) konstateren dat officials vooral bevreesd zijn, type 1 fouten te maken, dat wil zeggen te beslissen tot een overtreding terwijl de speler in feite geen overtreding heeft gemaakt. Men kan aangaande onze populatie, veronderstellen dat officièlen meer gewend aan, en ervaring hebbend in het 
leiding geven in tegenstelling tot niet-officiëlen, minder vrees zullen hebben dergelijke (beoordelings)fouten te maken; zif zullen dus niet aarzelen instrumentele overtredingen te bestraffen.

Het zou ons inziens niet juist zijn de verschillen in sanktietoepassing uitsluitend te verklaren vanuit het scheidsrechtersgedrag, immers sankties zijn in hoge mate het gevolg van een feitelijke gang van zaken.

We kunnen, uttgaande van het spelersgedrag, het volgende veronderstellen: spelers in de derde en vierde klasse hebben zowel met officiele als niet-officielle scheidsrechters te maken. Z1j kunnen in de loop der jaren ondervonden hebben dat officielen strakker de spelregels hanteren; het gedrag wordt daaraan aangepast dat wil zeggen men past ervoor op al te ernstige overtredingen te maken.

Wanneer we per type strafzaak (onderverdeeld naar aard en richting van de straf) de sankties van de scheidsrechterskategorleën bezlen, blijkt, dat alle scheidsrechterskategorleẹn reaktleve overtredingen meer met uit het veldzendingen bestraffen. Een indikatie dat onze interpretatie van instrumentee1/reaktief in respektievelijk minder en meer ernstig, juist zou kunnen zijn. Opvallend is, dat met name de instrumentele overtredingen door de officiëlen gekonstateerd, nauwelijks gevolgd worden door een uit het veld zenden.

Men zou dus kunnen stellen dat in ieder geval de instrumentele agressie loont: in de wedstrijd zelft blijkt de overtreding geen gevolgen voor de speler te hebben. Achteraf, na de wedstrijd zal hij ondervinden in welke mate de tuchtkommisste de overtreding nog verder bestraft.

\subsubsection{Sankties tuchtkommissie}

Onze veronderstellingen ten aanzien van de sankties van de tuchtkommissie zijn (zle hfdst. 4, par. 4.4): reaktieve overtredingen zullen zwaarder worden bestraft dan instrumentele-; overtredingen ten opzichte van de scheidsrechter zullen eveneens door de kommissie als meer ernstig beschouwd worden; met andere woorden, wanneer we strafzaken indelen naar aard en richting wordt ons inziens de lichtste sanktie toegepast ten aanzien van instrumentele overtredingen tegen spelers en de meest zware bif reaktleve overtredingen tegen scheidsrechters. 
Uiteraard speelt zoals in hoofdstuk 6 is aangegeven mee dat er samenhang bestaat tussen de scheidsrechterlijke sanktie en die van de tuchtkommissie; uit het veldzendingen worden meer bestraft met een onvoorwaardelijke sanktie (onvoorwaardelijk wil zeggen dat een speler minimaal éen wedstrijd niet mag meespelen).

In tabel $7.6 \mathrm{~A}$ wordt allereerst per scheidsrechterskategorie de incidentie van onvoorwaardelijke straffen weergegeven. Daarna, tabel $7.6 \mathrm{~B}$ wordt het $\%$ onvoorwaardelijke sanktles per type strafzaak per scheidsrechterskategorie vermeld.

Tabe1 $7.6 \mathrm{~A}$

Incidentie onvoorwaardelijke straffen tuchtkommissie* per scheidsrechterskategorie

scheidsrechterskategorleën officielen niet-off. totaa 1 $1 / 2$ klasse $3 / 4$ klasse

incidentie onvoorw. straffen

incidentie totaal aantal straffen

* inc. onvoorw. straf. tuchtk. $\frac{\text { aantal onvoorw. straf }}{\text { antal wedstrijden }} \times 100$

Tabe1 $7.6 \mathrm{~B}$

Percentage onvoorwaardelijke straffen per type strafzaak voor drie scheidsrechterskategorleën

scheidsrechterskategorleèn officiellen nlet-off. totaal $1 / 2$ klasse $3 / 4 \mathrm{klasse}$

$\begin{array}{lllll}\text { 1. Instr./speler } & 56 \% & 51 \% & 62 \% & 55 \% \\ \text { 2. instr./scheidsr. } & 56 \% & 57 \% & 69 \% & 57 \% \\ \text { 3. reakt./speler } & 77 \% & 85 \% & 95 \% & 82 \% \\ \text { 4. reakt./scheidsr. } & 50 \% & 53 \% & 85 \% & 54 \% \\ & --- & --- & --- & -- \\ \text { total } & 59 \% & 62 \% & 81 \% & 62 \%\end{array}$


Indien we de percentages onvoorwaardelijke straffen in de totaalkolom vergelijken blijkt éen type strafzaak, namelijk reaktleve overtredingen ten opzichte van de speler, verreweg het zwaarst te worden bestraft in vergelijking met de andere typen strafzaak.

Onze veronderstelling dat met name reaktieve overtredingen ten opzichte van de scheidsrechter ernstig zullen worden bestraft wordt door de resultaten dus niet bevestigd; een verklarlng voor de hier gevonden verschillen kan gelegen $z i j n$ in het verbale of fysieke karakter van de overtreding.

Ekkers en Hoefnagels (1972) vonden een duidelijke samenhang tussen (poging tot) fysileke agressie en een onvoorwaardelijke straf van de tuchtkommissie. 0ok bij ons onderzoek zou deze relatle een rol kunnen spelen; immers overtredingen tegen scheldsrechters dragen in tegenstelling tot die tegen spelers, voornamelijk een verbaal karakter.

Reaktieve overtredingen ten opzichte van spelers $z i j n$ bij uitstek van fysleke aard. Overigens zal bif bepaling van de strafmat bij dit type strafzaak de scheidsrechterlijke sanktie mede een rol spelen; immers in tabel $7.5 \mathrm{~B}$ is angetoond dat juist bif dit type strafzaken spelers uit het veld worden gestuurd.

Ook bij de relatie onvoorwardelijke straf tuchtkommissie en scheidsrechterskategorie zal de scheidsrechterlijke sanktie een rol spelen.

De tabellen $7.6 \mathrm{~A}$ en $7.6 \mathrm{~B}$ laten zien dat met name sankties van de niet-offlciellen gevolgd worden door een onvoorwaardelijke straf. Opvallend is in vergelijking met sankties van de officillen het hoge percentage onvoorwaardelijke straffen bij reaktieve overtredingen ten opzichte van de niet-officielen; opvallend omdat men met name bij de niet-officiëlen, behorend tot de thulsklub, enlgszins verwachten kan dat spelers op de scheidsrechterlijke onervarenheid reageren. Op basls van deze veronderstelling zou men van de tuchtkommissie enlge clementie verwachten ten aanzien van dit type overtreding.

Om na te gaan in hoeverre de scheidsrechterlijke sanktie hierin meespeelt geeft tabel 7.7 de percentages onvoorwaardelijke straffen per scheldsrechterskategorie, gesplitst naar waarschuwingen. Uit het veldzendingen, worden ongeacht de scheidsrechterskategorle, bijna altijd (gemiddeld 90\%) gevolgd door een onvoorwaardelifke schorsing van de tuchtkommissle en zijn dus niet in de tabel weergegeven. 
Tabe1 7.7 .

Percentage onvoorwaardelijke straffen tuchtkommissie per type strafzaak naar waarschuwingen.

\begin{tabular}{|c|c|c|c|c|}
\hline & & sche1 & chterst & gorleên \\
\hline & & ièlen & niet-c & totaal \\
\hline & $1 / 2 \mathrm{k}$ & $3 / 4 k$ & & \\
\hline $\begin{array}{l}\text { ard/richting } \\
\text { strafzaak }\end{array}$ & $\begin{array}{l}\text { waar- } \\
\text { sch. }\end{array}$ & $\begin{array}{l}\text { war- } \\
\text { sch. }\end{array}$ & $\begin{array}{l}\text { Waar- } \\
\text { sch. }\end{array}$ & $\begin{array}{l}\text { War- } \\
\mathrm{sch} \text {. }\end{array}$ \\
\hline 1. Instr/speler & 54 & 47 & 44 & 52 \\
\hline 2. instr/scheldsr. & 50 & 48 & 63 & 51 \\
\hline 3. reakt/speler & 70 & 76 & 84 & 72 \\
\hline 4. reakt/scheidsr. & 39 & 42 & 75 & 41 \\
\hline & --- & -- & --- & -- \\
\hline totalal & 53 & 53 & 66 & 54 \\
\hline
\end{tabular}

Het is opvallend dat juist bij de niet-officiellen 6ók waarschuwingen meer dan bij de twee andere kategorieën gevolgd worden door een onvoorwaardelifke straf; met andere woorden het hoge percentage onvoorw. straffen voor de niet-officielen uit tabel 7.6 wordt niet volledig verklaard door het relatief meer uit het veld sturen van deze kategorie scheidsrechters.

Dat het hier gevonden resultaat zou kunnen betekenen dat meer spelers in de derde en vierde klasse rondlopen met een reeds aanwezige strafkaart of voorwaardelijke straf kan niet door onze resultaten bevestigd worden omdat bij wedstrijden geleid door officiëlen in de derde en vierde klasse minder onvoorwaardelijke sankties worden gegeven.

Dit zou dus betekenen dat de tuchtkommissie in haar strafmat rekening houdt met de status van de scheidsrechter.

Elgenlijk zou men, gezlen de onervarenheld van de niet-officièlen en hun binding met de thuisklub, zoals al opgemerkt is op de vorige bladzijde, een zekere terughoudendheid in de sankties van de tuchtkommissies verwachten hetgeen meer voorwaardelijke straffen zou betekenen. Het tegendeel is echter het geval. Juist in die gevallen waarin een waarschuwing gegeven wordt wegens een overtreding tegen de nietofficiele scheidsrechters volgen relatief meer onvoorwaarde1ijke straffen! 
Een verklaring zou kunnen zifn dat de tuchtkommissies juist de nlet-officielen in hun positie als gezagsdrager van de bond, bevestigd willen zien. Met andere woorden spelers zullen ook indien wedstrijden geleid worden door niet-officielen, deze als wedstrijdleider moeten aanvaarden.

$7 \cdot 5$. Samenvatting

In dit hoofdstuk heeft het onderscheid aard (instrumentee1/reaktief) en richting (speler/scheidsrechter) overtreding centraal gestaan. Het is ons inziens legitiem geweest het onderzoeksmateriaal in te delen in een aantal wedstrijdtypen, waarin teder type wordt gekarakteriseerd door de in deze wedstrijden voorkomende overtredingen. In $76 \%$ van de wedstrijden komt één bepaald type overtreding voor.

onze hypothesen ten aanzien van de variabelen status scheldsrechter en klassenivo worden grotendeels bevestigd. De belangrijkste resultaten willen we per scheldsrechterskategorie samenvatten.

Tabe1 7.8.

Incidentie aantal strafzaken; meest gerapporteerde type strafzaak; incidentle uit het veldzendingen en incidentie onvoorwaardelijke straffen tuchtkommissie per scheidsrechterskategorle.

scheidsrechterskategorie ën officièlen

$1 / 2 \mathrm{klasse} 3 / 4 \mathrm{klasse}$

incldentie aant.strafzaken

38

21

$4 \cdot 3$

meest voorkomend

type strafzaak
Instrum/ speler
Instrum/ instrum/ scheidsr. scheidsr. reakt/sp.

Incidentie uit het veldzend. incidentle onvoorwaardelijke straffen tuchtkommissie niet-off. 
Spelers in de eerste en tweede klasse lopen de meeste kans een strafzaak te krijgen, uit het veld te worden gestuurd en onvoorwaardelijk te worden gestraft.

Wanneer we binnen de strafzaken de drie scheidsrechterskategorieèn met elkaar vergelijken blijken de officiellen in de eerste en tweede klasse vooral instrumentele overtredingen tegen spelers te bestraffen en rapporteren officielen in de derde en vierde kasse met name instrumentele overtredingen ten opzichte van hun eligen beleid. De twee kategorieën officiêle scheidsrechters hanteren voornamelijk de officięle waarschuwing als scheidsrechterlijke sanktie.

De niet-officiëlen rapporteren nauwelijks strafzaken; àls $z i j$ rapporteren $z i j n$ dit slechts sporadies instrumentele overtredingen tegen spelers, en passen zij verhoudingsgewijs meer de scheidsrechterlijke sanktie uit het veldzenden toe. 
HOOFDSTUK 8.

HET THUIS EN UITSPELEN

scheidsrechter:

"dit alles onder en talrijk laalend enthouslast publlek dat vaak hun afkeur t.a.v. het spel van de bezoekers ultte wat dan weer bij deze spelers overkwam als een soort doping om er vervolgens nog een schepje bovenop to doen."

aanwoerder gestrafte partiJ:

"volgens mij llet de scheldsrechter zlch duldelljk door het fanatlleke publlek in zljn besllssingen belnv laeden.

De houding van het publlek was zelfs af en toe dreigend ....... hllerdoor werden door ons soms overtredlngen gemaakt dle normaall nlet waren voorgevallen."

8.1. Inleiding

In dit hoofdstuk willen we nader ingaan op de relatie tussen het thuis- en uitspelen en het voorkomen van strafzaken. Onze laatste twee vraagstellingen (hfdst. 1, par. 1.2) kunnen derhalve getoetst worden. Dat aan dit onderwerp een apart hoofdstuk is gewijd, is met een aantal redenen te motiveren: In ons verslag is in hoofdstuk 5 de hypothese behandeld "welke faktoren bepalen het onderscheid tussen wedstrijden met en zonder strafzaken". De aard van deze vraagstelling, die een analyse op wedstrijdnivo vereist, maakt het niet mogelijk gebruik te maken van een variabele als thuis- en uitspelen. Dit manco doet zlch met name gevoelen omdat resultaat van ander onderzoek uitwijst dat het uitspelen een belangrijke determinant is voor het opgelegd krijgen van straffen (zie hfdst. 3 en par. 8.2).

Met andere woorden de eerste reden om het thuis - uitspelen te behandelen $1 \mathrm{~s}$ bespreking van de samenhang tussen het thuls en uitspelen en het voorkomen van strafzaken.

Naast toetsing van de veronderstelling of uitspelers inder- 
daad meer strafzaken krijgen toegewezen, is hierbij vooral het mogelijk verschil in scheidsrechtersbeleid tussen officiëlen en niet-officiëlen interessant.

Niet-officielen melden niet vaak strafzaken; als zif echter daartoe overgaan passen zij met name de sanktie uit het veld zenden toe. Het is de vraag of de binding van de niet-officièlen met de thuisklub, zi\ worden lmmers door de thuisklub aangewezen om de wedstrijd te leiden en zijn meestal lid van de thuisspelende vereniging, tot uiting komt in het strafzakenbeleid: Twee veronderstelilngen zijn hierbij mogelijk. De niet-officlele scheidsrechter kan zijn binding met de thuisklub niet loslaten; daardoor beoordeelt hif spelsituaties niet objektief en zal een "voorkeur" aan de dag leggen voor de uitspelers. Deze veronderstelling wordt nog versterkt door ons vermoeden dat uitspelers, die de specifleke positie van de niet-officiele scheidsrechter kennen zich kritisch ten opzichte van hem zullen gedragen. Dit betekent dat $z i j$ een grotere kans lopen op een officiele strafzaak.

Een andere, juist tegenovergestelde veronderstelling is, dat niet-officièlen juist iedere verdachtmaking, in de zin van het beoordelen van de thuisklub willen vermijden en derhalve juist thuisspelers eerder zullen bestraffen.

Een tweede reden om het thuis- en uitspelen te behandelen is de te verwachten relatie tussen het uitspelen en de aard en richting van de overtreding: onderzoeksresultaten (par. 8.2) wifzen uit dat de oorzaak dat uitspelers vaker overtredingen begaan, gelegen zou zijn in het zogenaamde thuisvoordeel (of uitnadeel); uitspelen betekent vaker verliezen; dit verliezen wordt beschouwd als oorzaak van frustratie of van versterking van reeds aanwezige frustratie.

Hoewel we in hoofdstuk 2 besproken hebben dat de werking van de diverse agressieteorieën niet strikt te scheiden is wordt vooral de frustratie-agressie teorie gekoppeld aan reaktieve agressie; dit betekent dat we over het algemeen een relatie verwachten tussen het uitspelen en reaktieve agressle.

De veronderstelling over de richting van de strafzaak is dan weer specifiek voor ons onderzoeksmateriaal.

omdat de niet-officiéle scheidsrechter aangewezen wordt en/ of lid is van de thuisspelende vereniging én omdat we veronderstellen dat hij door de uitspelers niet als objektief kan of wenst te worden gezien, verwachten wij een oververtegenwoordiging van strafzaken, waarin sprake is van een konflikt tussen uitspelers en niet-officiêle scheidsrechters. 
Allereerst wilen wij dit hoofdstuk beginnen met de weergave van eigen en andere onderzoeksresultaten betrekking hebbende op de samenhang tussen het thuis- en uitspelen en het voorkomen van straffen of strafzaken (par. 8.2).

Aan de hand van dezelfde onafhankelijke variabelen, die ook gebrulkt $z 1 j n$ in de tot dusverre gehanteerde diskriminantanalyse, willen we vervolgens nagaan welke faktoren bijdragen aan het onderscheid tussen straffen ten aanzien van thuis- en uitklubs (par. 8.3). Omdat de meeste faktoren het wedstrifdbelang en/of wedstrijdverloop weergeven willen we de analyses op wedstrijdnlvo verrichten.

Omdat in een wedstrijd meerdere strafzaken kunnen voorkomen hebben wij besloten voor een duidelijker interpretatie van de gegevens, afzonderlijke analyses te verrichten voor resp. wedstrifden met 1,2 en 3 strafzaken. Wedstrijden met meer dan drie strafzaken komen $z o$ weinig voor dat resultaten hierom minder betrouwbaar $z i j n$.

Overigens is bij deze analyses nog een methodiese opmerking op haar plaats. Bij wedstrijden met twee en meer strafzaken bedraagt het aantal groepen wartussen de variabelen onderscheld kunnen maken meer dan twee. In wedstrijden met bijvoorbeeld 2 strafzaken zijn 3 soorten wedstrijden mogelijk, respektievelijk 2 strafzaken voor thuis- of uitklub of één strafzaak voor beiden. Dit betekent dat er meer signifikante diskriminante funkties kunnen optreden.

De eerste diskriminantfunktie scheidt de groepen maksimaal. De tweede funktie onderscheidt groepen het best op basis van informatie die niet verklaard wordt door de eerste diskriminantfunktie (Klecka, 1980; Tabachnick en Fide11, 1983).

Vervolgens wilen wij in paragraaf 8.4 ingaan op de samenhang tussen de aard en richting van de overtreding en het thuis - en uitspelen.

Bij bespreking van deze samenhang wordt de strafzaak als analyse-eenheid gehanteerd. Argument voor deze keuze is, dat wil na willen gaan of de ernst van de scheidsrechterlijke sanktie en die van de tuchtkommissie verschilt ten aanzien van thuis- of uitklub indien wij de aard en richting van de overtreding konstant houden. Hoewel aangenomen mag worden dat met name een scheidsrechter zijn officielle straf zal baseren op de door hem gelnterpreteerde ernst van de overtreding en niet op het thuis- of uitspelen, willen we nagaan of de status van de scheidsrechter van invloed is op de wijze 
van sanktionering ten aanzien van thuls- of uitklub. Bij de sanktie van de tuchtkommissie vragen wij ons niet zozeer af of in de toepassing ervan onderscheid gemaakt wordt tussen thuis- of uitklub, maar of de kommissie in har sanktiebeleid korrigerend optreedt; we veronderstellen dat, indien de niet-officiele scheidsrechter een voorkeur aan de dag legt voor de uitklub in zijn strafbeleid, de tuchtkommissie bij dit strafbeleid een zekere korrektie hierin kan aanbrengen. Aandacht voor sankties betekent met andere woorden een keuze voor de strafzaak als analyse-eenheid hetgeen tevens een konsistentie van de beschrijving van sankties met hoofdstuk 7 betekent.

8.2 . Onderzoek ten aanzien van de relatie thuis-uitspelen en de kans op overtredingen of strafzaken

In onderzoek is aan de relatie tussen thuis- en ultspelen en overtredingen veel aandacht besteed.

De aan deze samenhang ten grondslag liggende verklaringen kunnen we in een aantal punten samenvatten (Albrecht, 1976, 1982; Edwards, 1979; Ekkers en Hoefnage1s, 1972; Fetz, 1959; Heisterkamp, 1975a, 1975b; Lefebvre, 1974; Schwartz, 1977; Varca, 1980; Volkamer, 1971).

1. objektieve feit van thuisvoordeel; thuisklubs behalen in het algemeen meer overwinningen; de bezoekende klub schat de kansen lager in, in verband met het uit-nadeel, men ervaart daardoor een gevoel van frustratie welke zich kan uiten in agressief gedrag (Ekkers en Hoefnagels 1972). Kranenborg (1980b) suggereert hierbij, dat, omdat thuisspelende teams vaker winnen, uitspelende teams meer verdedigen en daarom meer overtredingen maken (zle ook Bakker en Whiting, 1984).

2. sociale bepaldheld van het thuisvoordee1. Thuisspelers zijn genelgd gemotiveerd gedrag te vertonen waarvan ze geleerd hebben het te assoclëren met de beloning van sociale goedkeuring, terwijl goede prestaties van uitspelers stilzwijgend of met afkeuring worden beoordeeld; Schwartz (1977) spreekt van "dffferential reinforcement". Impliciet is hier de aanwezigheid en invloed van het publiek aan de orde.

Lefebvre (1974) stelt dat de uitklub op een vijandig publiek reageert door agressief op te treden ten opzichte 
van de tegenstander; de agressie wordt werschoven van het publiek naar het veld (displacement-teorie).

Lefebvre geeft hilerbij tevens een voorbeeld van de twee faktor -teorle (zie ook par. 2.3.4). Spelers proberen hun fyslologiese prikkels te etiketteren; die prikkels kunnen uitspelers gedeeltelijk toeschrijven aan een vijandig reagerend publiek.

3. waarnemingspsychologiese faktoren; de uitklub komt terecht in een voor haar ongewoon opties waarnemingsveld (tribunes, publiek, beplanting rondom het veld, zie o.a. Edwards, 1979). Dit niet vertrouwd $z 1 j n$ met de situatie leidt tot onzekerheid, daardoor daalt de frustratietolerantie en lat de spelers in kritiese situaties eerder agressief reageren (Fetz, 1959).

4. de scheldsrechter; Volgens Heisterkamp (1975a) is de positte van de scheidsrechter zodanig ("de eenzaamste man op het veld") dat hij bij bepaalde gevallen meer onbewust dan bewust steun zoekt, die hij, indien in het voordeel van de thulsklub fluitend, in feder geval bij het publiek zal vinden (zie ook Gabler, 1976).

5. Hoewel bulten ons speciflek onderzoekskader, namelijk een onderzoek naar thulsvoordeel bij basketballwedstrijden (Mizruch1, 1985) blijken nog een aantal andere faktoren belangrijk.

Thulsvoordeel blijkt samen te hangen met karakteristieken van de stad: verenigingen uit stadskernen in tegenstelling tot verenigingen ult stedelijke agglomeraties ("suburbans"), verenigingen met kleine stadions en reeds lang bestaande verenigingen winnen vaker "thuis".

Wif hebben vervolgens, van andere onderzoeken, een aantal onderzoeksvariabelen vergeleken, die de verhouding weergeven tussen straffen (overtredingen) ten aanzien van thuis- en ultklub. 
Overzicht 8.1 .

Literatuuroverzicht \% straffen of overtredingen ten aanzien van de uitklub

Albrecht

(1982)

Ekkers

Heis terkamp

(1975a)

Lefebvre

Volkamer

Wolf waarschuwingen

uit het veld

strafschop tegen

"alle" overtredingen

officielle straffen

uit het veld

strafschop tegen

gele kaarten

officiele straffen

uit het veld
$65 \%$

$71 \%$

$74 \%$

$52 \% *$

$67 \%$

$77 \%$

$74 \%$

$78 \%$

$56 \%$

$61 \%$

* uit dit onderzoek is (in tegenstelling tot de andere onderzoeken) door een aantal onafhankelijke deskundigen het aantal overtredingen bepaald.

Uit deze gegevens blijkt duidelijk dat de ultspelende klub meer overtredingen makt, c.q. strafzaken krijgt. Dat het hier in de meeste gevallen om $2 / 3$ tot $3 / 4$ van de gevallen gat mag frappant genoemd worden.

Alleen het $\%$ van het onderzoek van Volkamer (in tegenstelling tot de andere onderzoeken betrekking hebbend op het amateurvoetba1) ligt lets lager.

Tabe1 8.1 geeft de verhouding thuis-/uitspelen ten aanzien van de officielle straffen in het Limburgse afdelingsvoetbal.

Tabel 8.1.

Verhouding officielle straffen t.a.v. thuisof uitspelende klubs $(\mathrm{N}=2.664)$

thuisk1ub

uttklub

$\begin{array}{r}\% \\ 45 \% \\ 55 \% \\ \hline 100 \% \\ \hline\end{array}$

Onze resultaten vertonen overeenkomst met die van Volkamer. Beide onderzoeken hebben betrekking op amateur-wedstrijden. Het is echter voorbarig aan deze twee onderzoeken de konklusie te verbinden dat er bij amateurs in tegenstelling tot bij profs bij het uitspelen minder sprake zou zijn van "frustrerende" omstandigheden. 
8.3. Welke faktoren bepalen het onderscheid tussen wedstrijden met strafzaken ten aanzien van thuis- of
ultklub

Voordat we via diskriminantanalyse antwoord gaan geven op deze vraag willen we, omdat analyses verricht gaan worden voor wedstrijden met respektievelijk 1, 2 er 3 strafzaken de verhouding in deze wedstrijden beschrijven tussen strafzaken ten aanzien van thuis-uitklub.

Indien we voor wedstrijden met 2 en 3 strafzaken (zie tabel 8.2 ), die wedstrijden uitsluiten waarbij beide partijen in gelijke mate worden bestraft is de verhouding strafzaken ten aanzien van thuls- en uitklub, in zowel wedstrijden met 2 en 3 strafzaken $37-63$.

Dit betekent dat toename van aantal strafzaken per wedstrijd leidt tot toename van het aandeel van de ultspelende klub.

Tabel 8.2.

Verhouding strafzaken thuis-uitklub in wedstrijden met resp. 1,2 en 3 strafzaken.

wedstrijd

thuisklub uitklub strafzaak

$\mathbb{N}$

met 1

strafzaak $\quad 45 \% \quad 55 \%$

1115

wedstrijd

thuisklub uitklub beide

N

met 2

strafzaken

$17 \%$

$28 \%$

$55 \%$

418

3 strafz. 2 strafz. 1 strafz. 3 strafz. N

thuisklub thuisklub thuisklub uitklub

1 strafz. 2 strafz.

wedstrijd

uitklub uitklub

met 3

$\begin{array}{llllll}\text { strafzaken } & 9 \% & 37 \% & 40 \% & 15 \% & 160\end{array}$

Wanneer we nu overgaan tot de analyses dient men te bedenken dat het hier om wedstrijden met strafzaken gaat. Dit betekent dat bepaalde faktoren die een belangrijke bijdrage leverden aan het onderscheid al of niet strafzaken, de va- 
riabelen scheidsrechter en klassenivo, een andere verdeling laten zien dan bij een vergelijking wedstrijden met en zonder strafzaken. $92 \%$ van wedstrijden met strafzaken wordt geleid door officiële scheidsrechters en de wedstrijden spelen $z$ ich vooral af op het eerste en tweede klassenivo (64\% van het totaal). Daarom hebben wij, door deze "zelf-selektie" van wedstrijden, geen al te hoge verwachtingen ten aanzien van het percentage verklaarde variantie.

De resultaten zijn ondergebracht in tabe1 8.3. Daarin zijn alléen die variabelen vermeld die een signifikante verandering in RAO's $v$ bewerkstelligen $(P<.001)$.

Tabe1 8.3.

Diskriminantanalyses verhouding strafzaken thuis-ultklub bij wedstrijden met resp. 1,2 en 3 strafzaken ( $N=$ resp. 1008, $418,156)$. (Vermeld wordt bij alleen die variabelen die een signifikante verandering $(\mathrm{p}<.001$ ) in RAO's V bewerkstelligden, de hoogte van de gestand. diskr. funktiekoefficiënt)

wedstrijden

variabele

1 strafzaak

2 strafzaken

3 strafzaken

.winst/verlies $\quad-.80$

$-.70$

$-.67$

.status

scheidsrechter

- afstand

.27

- antal doe1p.

verklaarde

variantie

$8 \%$

$7 \%^{*}$

$11 \%^{*}$

De variabele winst/verlies is in alle analyses signiflkant. Met name het verliezen blijkt een belangrijke determinant voor het opgelegd krijgen van strafzaken: voor zowel thuis als uitklub geldt: verlies betekent een grotere kans op strafzaken.

Bij wedstrijden met 2 en 3 strafzaken komt één signifikante diskriminantfunktie voor. De hier vermelde percentages verklaarde variantie bij deze wedstrijden hebben betrekking op deze ene funktie. 
Omdat uitklubs vaker verliezen (zie hfdst. 5 par. 5.6) kan dit een verklaring zijn voor het, over het totaal gezien, grotere aandeel van de ultspelers bij strafzaken.

Het verliezen is in de door ons geraadpleegde literatuur eveneens als een belangriljke oorzaak van overtredingen of strafzaken beschreven (v.d. Brug, 1981; Lefebvre, 1974; Schmidt, 1979; Volkamer, 1971).

De tabellen $8.4 \mathrm{t} / \mathrm{m} 8.6$ verduidelijken de invloed van het al dan niet verliezen op het voorkomen van strafzaken. Interessant is het overigens dat, Indien we wedstrijden met gelijke spelen bezien ( $z$ le ook tabel 8.4 en 8.5 ), waarin in feite het effekt van winst/verlies wordt geneutraliseerd, ook in deze wedstrijden uitklubs meer strafzaken opgelegd krijgen.

Een algemeen aanvaard principe in het voetbal en naar we aannemen ook in het afdelingsvoetbal is, dat vooral in thuiswedstrijden de winst behaald moet worden. Dit betekent dat uftspelende elftallen meer verdedigend zullen opereren. Onderzoek (zie Bakker en Whiting, 198.4; en hfdst. 3: overzicht 3.1) wijst ult dat een verdedigende taktiek in het voetbal de kans vergroot dat overtredingen/strafzaken voorkomen. Met andere woorden het grote aandeel van de uitklubs in het aantal strafzaken kan niet alléen uit frustratie verklaard worden. Het spelen met een verdedigende techniek wijst meer op een leerteoreties principe.

De variabele status scheldsrechter is in 2 analyses signifikant: met name uftspelers worden door niet-officielle scheidsrechters gestraft (tabel 8.4 en 8.5 in de bijlage). Bij wedstrijden met 2 strafzaken komt het geen enkele maal voor dat een niet-officiele scheidsrechter de thuisklub allén straft; daartegenover wordt bij $58 \%$ van deze wedstrijden alleén de uitklub bestraft. Van alle strafzaken die een nlet-offlciele scheldsrechter aanmeldt heeft $76 \% \quad(N=158)$ betrekking op de uitspelende klub.

Dit resultaat bevestigt onze veronderstelling dat bij de niet-offlclële scheidsrechters vergeleken met de officielen een versterking van het intern rolkonflikt plaats vindt: thuisspelers worden beduldend minder bestraft. Tevens bevestigt dit een aspekt van de kognitieve teorieën waarin sprake is van het ervaren van een dissonantie, Indien men, individuen die men goed kent, zou straffen.

De belangrijkheld van de twee andere signifikante variabelen is beperkt: zij zijn slechts in Een analyse signifikant en 
de waarde van de diskriminantfunktie is betrekkelijk laag: Bij wedstrijden met één strafzaak komen bij een kleine afstand meer strafzaken ten opzichte van de thuisklub voor en bij een gemiddeld grote afstand meer strafzaken ten opzichte van de uitspelende klub. Een verklaring voor dit resultaat is vooralsnog moeilijk te geven.

Bij wedstrijden met twee strafzaken waarin veel doelpunten gescoord worden $k r i j g t$ ofwel de thuisklub dan wel de uitklub in veel gevallen beide strafzaken opgelegd. Doelpunten zorgen bij deze wedstrijden voor een versterking van een wellicht reeds aanwezlige frustratie.

Na verwerking van de gegevens uit de zojuist besproken diskriminantanalyses bleef voor ons nog een vraag onbeantwoord. Is het verliezen en de omzetting daarvan in overtredingen of strafzaken mede afhankelijk van of bepaald door het type scheidsrechter dat de wedstrijd leidt. Onder het type scheidsrechter verstaan we de door ons gehanteerde drie-deling in hoofdstuk 7: officiele scheidsrechters in respektlevelijk de eerste en tweede, en derde en vierde klasse en niet-officiele scheidsrechters.

Geeft met name verlies voor de thuisspelende of uitspelende klub in wedstrijden geleid door niet-officielen een evenredige kans op een strafzaak. Onze vraag hebben wij alleen via wedstrijden met eén strafzaak trachten te beantwoorden, omdat meerdere strafzaken in éen wedstrijd nauwelijks door niet-officiellen worden gegeven.

Tabel 8.7 .

Percentage wedstrijden waarin resp. de thuis- of uitklub verifest en een officielle straf krijgt opgelegd, per scheidsrechterskategorie (wedstrijden met 1 strafzaak

$\mathrm{N}=1115$ )

verliezende

thuisk1ub

officièle scheidsrechters

$1 / 2$ klasse $3 / 4$ klasse

nilet-officièle scheidsrechters

werliezende uitk1ub

$60 \%$

$62 \%$

$46 \%$

uitklub

$60 \%$

$69 \%$

$85 \%$

In wedstrijden geleid door officiele scheidsrechters bestaat er global genomen een ongeveer even grote kans dat indien de thuis- of uitklub verliest $z 1 j$ een strafzaak toegewezen krijgen. Met andere woorden verlies betekent voor beide par- 
t1jen een evenredige omzetting van het verlies in overtredingen of agressief gedrag *

Bij wedstrijden geleld door niet-officièlen liggen deze cijfers totaal anders. Zelfs in wedstrijden warin de thuisklub verllest zorgt $z i j$ voor "slechts" $46 \%$ van het totaal aantal strafzaken in die wedstrijden, terwij1 de verliezende uitklub $85 \%$ van het aantal strafzaken voor haar rekening neemt. Vanuit de spelerspositie bezlen kan de niet-officiêle scheidsrechter als nlet-objektief beschouwd worden; verlies zou door uitspelers dan nog een ekstra frustratie betekenen, waardoor er gerede kans bestaat dat deze frustratie omgezet wordt in agressie.

Omdat de verliesfaktor voor zowel thuis- als uitklub bif officlëlen in de derde en vierde klasse bijna in gelijke mate wordt omgezet in strafzaken kunnen we ons niet voorstellen dat verlies voor de thuisklub onder leiding van een nietofflciele scheidsrechter een andere betekenis zou hebben. De konklusile moet derhalve luiden dat gezien zijn binding met de thuisklub de wedstrijjdleider een zekere mate van partijdigheid vertoont b1j het waarnemen en beoordelen van bepaalde spelsituaties in de wedstrijd.

Een konklusie die in de volgende anekdotes tot uiting komt:

reaktle bestuur ultspelende klub op de wedstrljdlelder:

"... door en duldelijke voorkeur aan de dag te leggen voor ploeg $X$ en de spelregels slechts in het voordeel van "zilj" elftal te laten blijken" "... nlet alleen door het negeren van zware overtredingen van "zlJn" spelers maar vooral door de wedstrljd nilet +ljdig af te "lulten..."

"... en floot af toen zljin klub elndelljk de geI IJkmaker scoorde."

gestrafte speler:

"het is herhaldellyk het geval dat als men ult moet spelen on de tegenstanider zellf voor een scheldsrechter moet zorgen, deze wedstrlljd partijdlg gefloten wordt." 
8.4. Samenhang tussen thuis-uitspelen en aard-richting overtreding

Zoals in de inleiding van dit hoofdstuk is besproken willen we nagaan in hoeverre er samenhang bestaat tussen de aard en richting van de strafzaak en het thuis- en uitspelen. Met name interesseert ons de veronderstelde relatieketen uitspelen-frustratie-reaktieve agressie.

Dat wij in deze paragraaf de sanktie van scheidsrechter en tuchtkommissie behandelen wordt niet zozeer verklaard door een veronderstelling dat de scheidsrechter in het toepassen van sankties rekening houdt met het thuis- of uitspelen maar vindt meer zijn oorzaak in de aard van ons onderzoeksmateriaal. Omdat niet-offlciele scheidsrechters gekozen worden door en behoren tot de thuisklub veronderstellen wij dat zij niet alleen de thuisspelers minder bestraffen (zie paragraaf 8.3) maar dat $z 1 j$ hen ook lichter zullen bestraffen; ten aanzien van de sanktie van de tuchtkommissie verwachten we dat zij sankties van de niet-officiele scheidsrechters ten opzichte van de uitspelende ploeg met enige gereserveerdheid zal beoordelen en wellicht korrigerend zal optreden.

W1j zifn per scheldsrechterskategorie nagegaan in hoeverre zij in het toepassen van officiele straffen ten aanzien van thuis- of uitklub onderscheld maken in de aard en richting van de overtreding.

De resultaten hiervan worden in tabel $8.8 \mathrm{~A}$ en $8.8 \mathrm{~B}$ weergegeven; tabe1 $8.8 \mathrm{~A}$ geeft allereerst, omdat dit in de analyses van paragraaf 8.3 nog niet als zodanig is weergegeven, de incidentie van respektievelijk strafzaken ten aanzien van thuis- en uitklub per scheidsrechterskategorie.

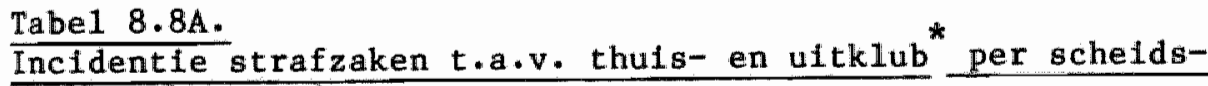
rechterskategorie.

scheidsrechterskategorle officielen niet-off. totaal

$1 / 2$ klasse $3 / 4$ klasse

incidentie thuis 18 incidentie uit
18

20
10

12
$1 \cdot 1$

3.2

* Incidentie strafz: aantal strafz. thuis of ultklub $\times 100$ thuis of uitklub : aantal wedstrijden 
Tabe1 8.8B.

Aandeel uitk lub in type strafzaak

per scheldsrechterskategorle $(N=1462)$

scheldsrechterskategorie officièlen nlet-off. totaal

type strafzaak

$1 / 2$ klasse $3 / 4$ klasse

instr./speler

instr./scheidsr.

reakt./speler

reakt./scheidsr.

total
$50 \%$

$60 \%$

$45 \%$

$57 \%$

$--$

$52 \%$
$53 \%$

$57 \%$

$52 \%$

$57 \%$

$--$

$55 \%$
$59 \%$

$91 \%$

$53 \%$

$95 \%$

$--$

$76 \%$
$51 \%$

$62 \%$

$48 \%$

$60 \%$

$-$

$55 \%$

Door ons is verondersteld dat uitspelers reaktieve agressie zouden begaan. Echter, voor alle scheidsrechterskategorieën geldt dat niet verschillen in aard van de strafzaak, maar juist in richting ervan optreden. Thuis- en uitspelers worden in ongeveer gelljke mate bestraft met overtredingen ten opzlchte van spelers; opvallend is dat op het eerste en tweede klassentvo thuisspelers daarbij meer reaktieve overtredingen begaan. Uitspelers worden meer bestraft met overtredingen ten opzlchte van de scheidsrechter; een konklusie die vooral opgaat bij wedstijden geleid door niet-officielen. Het zal duidelijk zijn dat de binding van de niet-officielen met de thulsklub, al dan niet terecht door de uitspelers als niet objektief beoordeeld, hierin een belangrijke rol speelt.

Omdat niet-officiellen bijna overwegend uitspelers bestraffen ten aanzien van hun scheidsrechterspositle is het in dit verband zinvol, de resultaten van tabel $7.6 \mathrm{~B}$ en 7.7 uit hoofdstuk 7 te memoreren.

Uit deze tabellen werd 0.a. de konklusie getrakken dat met name reaktleve overtredingen ten opzichte van niet-officiele scheldsrechters gevolgd worden door een onvoorwaardelijke schorsing van de tuchtkommissie. Dit betekent dus dat gezien de resultaten van tabe $18.8 B$ vooral uitspelers deze onvoorwaarde11jke straffen oplopen.

Ook Ekkers en Hoefnagels (1972) komen tot gelijksoortige resultaten: de verhouding strafzaken thuis-ult is bij verbale agressie (bijna uitsluitend ten opzlichte van de scheidsrechter) $5: 1$ en bij (poging tot) fysieke agressie (bijna uitsluttend ten opzichte van spelers) $1: 1$. 
Een verklaring voor dit resultaat is volgens hen moeilijk te geven. Ons inziens kan een veronderstelling voor de resultaten zijn dat het behalen van winst voor de thuisklub zo'n vaststaand gegeven, is dat iedere (dreigende) blokkering ervan leidt tot overtredingen ten opzichte van spelers; wif gaan er hierbij van uit dat overtredingen ten opzichte van spelers meer uitdrukking $z i j n$ van het direkte wedstijdverloop dan de meer indirekte (verbale) agressie ten opzichte van de scheidsrechter.

Vanult de positie van de uitspelers geredeneerd kan de scheidsrechter om welke reden dan ook als "thuisfluiter" worden waargenomen en/of ervaren, hetgeen uiteraard de kans op agressie ten opzichte van zijn positie aannemelijk makt. De veronderstelling door ons geopperd, dat de uitspelende klub om wat voor reden dan ook (thuisvoordeel, omgeving, scheldsrechter) meer gefrustreerd is of raakt dan de thuisklub en meer reaktieve overtredingen begat wordt door de gegevens niet bevestigd. Met andere woorden, de resultaten zijn niet in overeenstemming met de frustratie-agressie hypothese.

Indien we per scheidsrechterskategorie nagaan in hoeverre ten aanzien van thuis- of uitklub verschillen optreden in scheidsrechterlijke sanktie blijken deze verschillen konform onze veronderstellingen gering (zie bijlage tabel 8.9, waarin gespecificeerd is in aard en richting overtreding). Opvallend is alleen dat als niet-officièlen de thuisspelers bestraffen, en $z i j$ doen dit slechts bij $23 \%$ van alle door hen aangemelde strafzaken, zij thuisspelers meer uit het veld sturen.

Onze veronderstelling hierbij is dat de thuisspeler indien door de niet-officiele scheidsrechter bestraft, een zodanig ernstlge overtreding gemaakt moet hebben, dat slechts een ernstige scheidsrechterlijke sanktie kan volgen.

Tenslotte hebben wij ons afgevraagd of de tuchtkomissie in haar sanktiebeleid onderscheid maakt tussen thuis- en uitklub.

Over het algemeen $z i j n$ er geen grote verschillen aanwezig. Het percentage onvoorwaardelijke straffen ten aanzien van de thuisklub bedraagt 63 en ten aanzien van de uitklub 61 . ook indien we per scheidsrechterskategorle differentieren naar aard en richting van de overtreding en/of scheidsrechterlijke sanktie treden weinig grote verschillen op. Voor de overzichtelijkheid hebben wij in tabel 8.10 alleen de per- 
centages onvoorwaardelijke straffen per scheidsrechterskategorle weergegeven (bijlage tabel 8.11 geeft informatie gespectficeerd naar aard en richting van de overtreding).

Tabe1 8.10.

\% onvoorwaardelijke straffen tuchtkommissie t.a.v. thuisen uitklub per scheidsrechterskategorie (alle strafzaken: $\mathrm{N}=2664$ )

scheldsrechterskategorie officieel niet-off. totaal $1 / 2$ klasse $3 / 4$ klasse

\% onvoorw. straffen t.a.v. thuisklub \% onvoorw. straffen t.a.v. uitklub

61

58

$-$

59
65

60

62
85

80

$--$

81
62

Dat bij officiele scheidsrechters in de eerste en tweede klasse meer onvoorwaardelijke straffen aan de thuisklub worden gegeven is te verklaren vanuit het relatief grote aandee] van de thuisklub van reaktieve overtredingen ten opzichte van spelers; overtredingen, die door scheidsrechters zwaar worden bestraft.

De oververtegenwoordiging van percentages onvoorwaardelijke straffen van de thulsklub bij officiëlen in de derde en vierde klasse is moellijk te verklaren. Vooral, indien we de strafzaken specificeren in aard en richting, blijkt de thuisspeler bij instrumentele overtredingen ten opzichte van spelers zwaarder door de tuchtkommissie te worden bestraft. De belangrijkste konklusie ten aanzien van de niet-officielen is dat onze veronderstelling dat de tuchtkomissle sankties ten opzichte van uitspelers milder bestraft door de resultaten wordt tegengesproken. Immers, zowel thuis als uitspelers, worden vergeleken met de sankties van tuchtkommissie bij de offlcielen meer onvoorwaardelijk gestraft. Onze konklusie uit hoofdstuk 7 dat de tuchtkommissie ten opzichte van de spelers de niet-officiele scheidsrechter als volwaardig gezagsdrager erkend wenst te zien zou derhalve gehandhaafd kunnen blijven. 
Wanneer we nagaan in hoeverre wedstrijden waarin vooral strafzaken aan de thuisklub gegeven worden, verschillen van wedstrijden waarin vooral de uitklub strafzaken krijgt, blijkt het belangrijkste verschil in deze wedstrijden de ultslag te zijn: verliezen betekent voor zowel thuis als uitklubs gemiddeld meer strafzaken.

Met andere woorden een sport waarin het kompetitiesysteem, gehanteerd wordt zoals in de voelbalsport, leldt ertoe dat "het winnen" centraal staat; wordt het doel geblokkeerd dan is er een gerede kans dat overtredingen $c . q$ * strafzaken volgen.

In die zin is de frustratie-agressie teorie op deze situatie toepasbaar.

Eén van de elementen van deze teorie is dat agressle, voortkomend uit frustratie eerder een reaktief karakter zal dragen. Dit zou betekenen dat, toegepast op ons onderzoeksmateriaal, de uitklub over het gehele seizoen gezien vaker verliezend, meer zou voorkomen bij reaktieve overtredingen ten opzichte van speler of scheidsrechter; onze resultaten geven hiervoor echter geen duidelijke bewijzen.

Het onderscheid instrumenteel/reaktlef is namelijk minder duidelijk dan het onderscheid speler/scheidsrechter: aan uitspelers worden meer strafzaken opgelegd waarin een overtreding ten opzichte van de scheidsrechter centraal staat. Het groter aandeel van de uitklubs is niet alleen via het verliezen te verklaren; immers ook in gelijke spelen krijgen zij meer strafzaken.

Dit laatste resultaat is waarsch 1 jnlijk een gevolg van een verdedigende taktiek van de uitklub; onderzoek heeft uitgewezen dat met een dergelijke taktlek de kans op overtredingen groot is (Bakker en Whiting, 1984).

Een andere belangrijke konstatering uit dit hoofdstuk is, dat voor het onderscheid strafzaken thuls - ultklub de status van de scheidsrechter belangrijk is: niet-offlcielen bestraffen meer uitspelers $(81 \%)$.

Analyse van dit laatste gegeven deed bij ons het vermoeden rijzen dat zelfs de uitslag mede bepaald zou kunnen worden door de niet-officiëlen. Van de 3500 wedstrijden (van hfdst. 5) $z i j n$ we daarom nagegaan in hoeverre er samenhang bestaat tussen de ultslag en de status van de scheldsrechter. Wel1s- 
waar werd door de thuisklub in wedstrijden met niet-officlèlen mér gewonnen $49 \%$ ten opzichte van de twee andere scheidsrechterskategorieën 41 en $43 \%$ maar de samenhang (tau B) was niet signifikant.

Gezien de binding van de niet-officlëlen met de thuisklub, zou men van de tuchtkommlssie enige gereserveerdheid verwachten bij het toepassen van sankties naar aanleiding van strafzaken aanhangig gemaakt door niet-officièlen.

De resultaten wijzen echter uit dat de (strenge) sankties van de niet-offictëlen gevolgd worden door, vergeleken met de andere scheidsrechterskategorieën, een hoog percentage onvoorwaardelijke straffen $(82 \%)$. 
HOOFDSTUK 9.

RONKLUSIES EN AANBEVELINGEN

In dit hoofdstuk staan twee vragen centraal.

1. Wat is de wetenschappelijke betekenis van de resultaten; wat is de bruikbaarheid van de gehanteerde onderzoeksmethode en de door ons gebruikte teoretiese uitgangspunten (par. 9.1).

2. Wat is de praktiese betekenis van de resultaten; bij deze vraag willen we ingaan op de door ons geformuleerde algemene probleemstelling.

Welke konklusies kunnen we trekken uit de resultaten betrekking hebbend op aantal en aard van strafzaken in het amateurvoetba1; welke faktoren beinvloeden strafzaken en welke gevolgen hebben zij (par. 9.2).

Belde paragrafen worden afgesloten met respektievelijk onderzoeks- en beleidsaanbevelingen.

9.1. Wetenschappelijke betekenis resultaten

9.1.1. Teorie

De opmerkingen over de door ons gebruikte teorieèn $z i j n$ te onderscheiden in opmerkingen over de zogenaamde agressieteorieèn, deze teorieèn pogen het spelersgedrag te verklaren, en over rol- en cognitieve teorieën, die met name het scheidsrechtersgedrag trachten te doorgronden.

Voordat we ingaan op deze teorieen stellen we vast dat geen standpunt is ingenomen over de inhoud van het begrip agressie. De belangrijkste reden hlervoor is dat wij van mening zijn dat het onmogelijk zal zijn een definitie van agressie te geven, warin rekening is gehouden met alle in de literatuur gevonden nuanceringen. Daarom hebben wif slechts de contouren geschetst waarbinnen sprake zal zijn van agressief gedrag. Ons inziens zijn in ieder geval de elementen opzet, schade en normstrijdigheid aanwezig bij agressief gedrag. Ondat er bijna altijd diskussie platsvindt over het al dan niet aanwezig zijn van de drie door ons genoemde elementen kunnen we het begrip agressie beschouwen als een idealtype. 
Agressieteorleën

Scheldsrechterlijke beslissingen vormen de bron van ons onderzoeksmaterial. Iedere beslissing is het gevolg van het door de scheidsrechter gehanteerde selektlemechanisme; een mechanisme dat nlet voor alle scheidsrechters identlek is. Strikt gezien is het de vraag, of alle overtredingen die tot een strafzaak leiden, beschouwd kunnen worden als uitingen van agresslef gedrag. Scheldsrechters interpreteren spelsituatles én daarmee gepaard gaande overtredingen nu eenmaal verschillend.

Ondanks deze verschillen kunnen we ervan uitgaan dat in veel gevallen sprake is geweest van agressief gedrag; hiervan uitgaande $1 s$ het hanteren en toepassen van de zogenaamde agressleteorleen aanvaardbaar.

De vraag die men zich aan het eind van een onderzoeksverslag kan stellen is welke agressleteorie nu het meest bruikbaar is geweest.

W1j hebben duldelijk gemaakt dat veel onderzoeken naar agressie in de voetbalsport de gehanteerde varlabelen nauwe$11 \mathrm{jks}$ koppelen aan teoretiese uitgangspunten.

In ons onderzoek hebben wif de koppeling tussen variabelen en agressieteorfeèn tot stand gebracht met behulp van drie faktoren: het belang van de wedstrijd, de soclale kontekst en het thuis-uitspelen.

Een eerste konklusie is dat alle drie faktoren in meer of mindere mate een rol spelen bif het vergelijken van wedstrijden met instrumentele of reaktieve overtredingen en wedstrifden zonder strafzaken; in eén of meerdere (diskriminant-) analyses bleken de faktoren signifikant.

Dit betekent dat de met deze vormen van agressie verbonden frustratle-agressle-, emotie-aktivatie- en leerteorie brulkbaar zijn geweest.

Door de aard van ons onderzoeksmaterlaal konden wif vooral beschikken over variabelen die het wedstrijdbelang vertegenwoordigen.

De meeste van deze belangvariabelen zijn belangrijk bij het onderscheid tussen wedstrifden met strafzaken (met name wedstijden met instrumentele overtredingen) en wedstrijden zonder strafzaken. Vooral variabelen die het direkte wedstrijdverloop vertegenwoordigen zijn hierbij belangrijk. Dit resultaat kan min of meer logies genoemd worden; faktoren die direkt bif het wedstrijdgebeuren betrokken zijn, moeten ge- 
acht worden een vorm van agressie die funktie in het spel heeft, namelijk de instrumentele agressie, te kunnen verklaren.

De afstand is de enige "belangvariabele" die een signifikante bijdrage levert aan het onderscheid tussen wedstrijden met reaktieve overtredingen ten opzichte van de scheidsrechter en wedstrijden zonder strafzaken.

Omdat deze variabele verder van het wedstrijdgebeuren afstaat was het, achteraf gezien, wellicht beter geweest haar in te delen bif de zogenaamde sociale kontekstvariabelen. Afgezien van het feit of de afstand nu een belangdimensie danwel een sociale kontekst vertegenwoordigt is ons inziens een belangrijkere konklusie dat het in veel gevallen moei$11 \mathrm{jk}$ is aan te geven of een bepalde kategorie variabelen (zoals bijvoorbeeld de "belangfaktoren") zich uit in instrumenteel of reaktief agressief gedrag.

De twee vormen van agressie zijn nauw met elkaar verweven. Niet alleen is het vaak in de praktijk moellijk uit te maken of gedrag een uiting is van instrumentele of reaktleve agressie, ook is het aannemelijk (Ekkers en Hoefnagels, 1972) dat instrumentele agressie, reaktieve agressie in de hand werkt.

Dit alles doet ons konkluderen dat de werking van de verschillende agressie-teorieèn niet altijd strikt te scheiden is. In de praktiese situatie zal het derhalve moeilijk uit te maken zijn welke specifieke agressleteorie van toepassing is. Met name bij het voorspellen of verklaren van reaktieve agressie, agressie met in principe geen funktie in het spel, spelen allerlei andere mechanismen een rol; mechanismen die in een onderzoek als hier beschreven niet aan de orde zijn gekomen.

Een laatste konklusie ten aanzien van de bruikbaarheld van de agressieteorleen is, dat onze onderzoeksvariabelen geen antwoord geven op het waarom van agressief gedrag, maar antwoord kunnen geven op de vraag "wanneer bestaat er gerede kans op agressie".

Rol- en cognitieve teorieën

Er is op gewezen dat, hoewel veel onderzoeken ultgaan van de door de scheidsrechter geregistreerde overtredingen, zij weinig aandacht schenken aan de teoretiese betekenis van de positie en rol van de scheidsrechter. 
Ons materiaal makt duidelijk dat jufst in dit soort onderzoeken sprake is van "'rate producing behavior"; het grote verschil tussen officièle en niet-officlèle scheidsrechters 13 , dat de laatste kategorie nauwelijks strafzaken aanmeldt. $B i j$ een vergelifking tussen officlellen onderling zijn er verschillen in typen gekonstateerde overtredingen: officielen op een hoog klassenivo konstateren meer instrumentele overtredingen ten opzlchte van spelers; officiellen in de lagere klassen (evenals de niet-officiellen) rapporteren meer instrumentele overtredingen ten opzichte van hun eigen positie; in dit geval is het wellicht beter te spreken van gedrag dat verschil veroorzaakt in de aard van de gekonstateerde overtredingen en niet in het aantal overtredingen. Wij zijn er ons van bewust dat de door ons toegepaste aspekten van rol- en cognitieve teorieèn vooral betrekking hebben op de spectfleke aard van ons materiaal, namelijk het onderscheid tussen officièle en niet-officielle scheidsrechters. ondanks het feit dat in veel onderzoeken alleén officiële scheidsrechters wedstrijden leiden moet het ons inziens mogelijk $z 1 j n$ een aantal "scheidsrechters-variabelen" op te nemen in toekomstig onderzoek; te denken valt hierbij aan bijvoorbeeld de leeftijd van scheidsrechters of het aantal jaren ervaring met het leiden van wedstrijden. Deze variabelen zouden dan als mogelijke verklarlng kunnen dienen voor het waarnemen, beoordelen en rapporteren van overtredingen of strafzaken.

Dit betekent dat de rol- en cognitleve teorieẻn die in het onderzoek het scheidsrechtersgedrag teoreties trachten te verklaren ook in andere onderzoeken funktioneel kunnen zijn.

Relatie teorie - metode

Onze laatste opmerking over de door ons gebruikte teorieên heeft te maken met de samenhang tussen onderzoeksmetode en teorletoepassing .

In hoofdstuk 1 hebben wlj aangegeven dat de keuze van strafdossiers als onderwerp van onderzoek o.a. tot gevolg had dat wij geen spelers benaderden om bifvoorbeeld hun mening over agresslef gedrag te vernemen. De mening van spelers kan uiteraard in een dergelijk onderzoek uiterst funktioneel zijn.

Twijfel of, zoals in ons onderzoek, inderdaad in alle gevallen sprake is geweest van agressief gedrag zou men, bijvoorbeeld, kunnen verminderen door niet alleen af te gaan op de 
scheidsrechterlijke beoordellng, maar door ook het oordeel van de betrokken partijen erin te betrekken (zie ook Gabler, 1976). Immers indien alle partijen het erover eens zijn dat een opzettelijke overtreding heeft plaats gevonden, kan men ervan uftgaan dat sprake is van agressief gedrag.

Een dergelijke aanpak stuit echter op een aantal specifieke problemen; problemen die we aan de hand van ons eigen onderzoeksmateriaal willen beschrijuen.

De rapportformulieren strafzaken (bijlage 1.3 en 1.4 ) geven beide $k$ lubs de gelegenheld aan te geven welke omstandigheden aanleiding hebben gegeven tot de overtreding; tevens wordt de partijen de gelegenheid geboden in een toelichting hun visie op het gebeurde te geven. Deze toelichting is door ons in éśn op de zes strafzaken gekodeerd als het al dan niet juist zijn van de scheidsrechterlijke beslissing. De gestrafte partij verwijst bij de vraag naar de omstandigheden die geleid hebben tot de scheidsrechterlijke sanktie in $19 \%$ van de strafzaken naar het gedrag van de tegenspeler en in $24 \%$ naar het scheidsrechterlijk gedrag. Voor de niet gestrafte partij is het percentage in beide gevallen $4 \%$. Bif de toelichting op het gebeuren b1ijkt dat in ca. $80 \%$ van de strafzaken slechts een versie van het gebeuren wordt gegeven, zonder dat wordt ingegaan op het al dan niet juist zijn van de scheidsrechterlijke beslissing.

Van de overige $20 \%$ blijkt $15 \%$ van de gestrafte en $4 \%$ van de niet gestrafte partij het niet eens te zijn met de beslissing van de scheidsrechter.

Wij willen met deze gegevens duidelijk maken dat bij o.a. inhoudsbepaling van agressie rekening gehouden moet worden met de interpretatie van het gebeuren door met name de gestrafte partij; deze partij geeft in het licht van het zo gunstig mogelifk weergeven van de situatie, een interpretatie gericht op een te verwachten sankt1e. Dat deze weliswaar interessante vragen niet meegenomen zijn in het onderzoek heeft daarom vooral een teoretiese achtergrond: wij menen dat dergelijke vragen gerelateerd kunnen worden aan $0 . a$. het symbolies interaktionisme dat o.a. teoretiese onderbouw levert voor "het definiẻren van de situatie (o.a. Cicoure1, 1976; Z1jderveld, 1973; Sykes en Matza, 1968; de Rldder, 1980); met andere woorden een teoretlese inbreng die duidelijk verschilt van de door ons gehanteerde agressieteorieẽn. 


\subsubsection{Metode}

Naast opmerkingen over de gehanteerde teorieen en de relatie tussen teorle en metade is een metodiese opmerking op zijn plaats; het gaat on de wijze van het definièren van agresslef gedrag.

Wij hebben respektievelijk wedstrijden met allén waarschuwingen $(\mathrm{N}=285)$ en alleen uit het veldzendingen $(\mathrm{N}=829)$ vergeleken met een ongeveer evengroot aantal wedstrijden zonder strafzaak. De eerste vergelijking leverde een verklaarde variantie op van $31 \%$ met de variabelen klassenivo, status scheidsrechter, seizoensverloop, doelpuntenverschil en rangverschil; de tweede vergelijking, alleen uit het veldzendingen leverde een verklaarde variantie op van $10 \%$ met de variabelen urbanisatiegraad en status scheidsrechter. Met andere woorden een verschillende operationalisatie van agressief gedrag beinvloedt het \% verklaarde variantie en aantal én aard van de signifikante variabelen.

\subsubsection{Plaats onderzoek in bestaande onderzoekstraditie}

Allereerst willen wij dit onderzoek plaatsen in de rij van andere onderzoekingen op dit gebied en vervolgens relateren aan de andere resultaten van het Deelprojekt "De invloed van spelregels op spelgedrag en spelverruwing".

Alleen al vanuit het gezichtspunt van het verschaffen van informatie is een onderzoek zoals hier uitgevoerd met een analyse van mér dan 12.000 wedstrijden waardevol geweest. Teoretiese besplegelingen over bijwoorbeeld het thuisvoordeel krijgen een empiriese basis; ook in het laagste amateurvoetbal blijkt immers de thuisklub vaker te winnen en (gedeeltelijk) daarmee samanhangend minder strafzaken opgelegd te krijgen.

Een ander voordeel van dit onderzoek is, nast de grootschaligheid, dat, in tegenstelling tot de meeste andere onderzoeken op dit terrein, telkenmale een vergelijking gemaakt kon worden tussen wedstrijden met en zonder strafzaken. Ons inziens krijgen de resultaten door het hanteren van een dergelifke kontrole-groep meer reliêf.

Getracht is in dit onderzoek de teorievorming ten aanzien van agressie of agresslef gedrag enigszins krities te bezien; daarbij is getracht de positie en rol van de scheidsrechter enig teoreties fundament te geven. Dit laatste wordt door de meeste onderzoeken achterwege gelaten. 
Afgezien van de verschillen in metode en populatie, in vergelijking met andere onderzoeken, stemmen de resultaten in grote lijnen overeen. Dit betekent dat het voorkomen van strafzaken beinvloed wordt door faktoren die ook in andere onderzoeken mede bepalend $z$ ijn voor agressief gedrag; namelijk het wedstrijdbelang, het verliezen en (daarmee samenhangend) het uitspelen.

In het eerste hoofdstuk is de plaats van dit onderzoek uitgelegd in het kader van het Deelprojekt "'invloed van spelregels op spelverruwing en spelbederf" aan de Rijksuniversiteit Limburg.

Resultaten van andere onderzoeken in dit deelprojekt toonden aan dat in de voetbalsport zowel scheidsrechters onderling als spelers onderling weinig overeenstemming vertoonden in het beoordelen van spelregels en spelsituaties.

Doordat de voetbalsport mogelijkheld biedt tot ruime interpretatie van de spelregels is tevens de bron aanwezig voor het verschillend beoordelen van datgene wat als agressief gedrag beschouwd mag worden.

Onze onderzoeksresultaten maken duidelijk dat, indien we scheidsrechters onderverdelen in een aantal kategorieën, deze kategorieën verschillen laten zien in aantal en aard van de aangemelde strafzaken; dit resultaat sluit derhalve aan bij de andere resultaten van het deelprojekt.

Dit verschil in scheidsrechterlijke toepassing van de spelregels maakt eens te meer duidelijk dat datgene wat oorspronkelijk als onderzoeksvraag bij ons was opgekomen, namelijk de relatie tussen selektiemechanismen van scheidsrechters en hun feitelijk gedrag op het veld, nader onderzoek verdient.

Een dergelifke relatie als onderzoek kent ulteraard een groot aantal varianten. Aanbeveling zou het verdienen het feitelijk gedrag op het veld niet alleen te beperken tot strafzaken, mar alle door de scheldsrechter wargenomen overtredingen in het onderzoek op te nemen, hoewel wij er ons van bewust $z i j n$ dat de praktiese uitvoering van een dergelifk onderzoek niet eenvoudig zal zijn.

Door alle overtredingen in een dergelifk grootschalig onderzoek op te nemen zou o.a. inzlcht verkregen kunnen worden in de samenhang tussen aantal en aard van de overtredingen en aantal en aard van de strafzaken. 
Naast mogel1jkheden van ander onderzoek is het opnemen van andere variabelen in het type onderzoek, zoals door ons is ultgevoerd, mogelljk:

Bijeen vergelijking van wedstrijden met en zonder strafzaken:

- uitslag vorige wedstrijd(en) - in hoeverre werkt winstverlies door op het spelersgedrag.

- leeftijd, ervaring scheldsrechter - invloed op het al dan niet waarnemen en beoordelen van spelsituaties.

Bij een analyse van wedstrijden met strafzaken:

- stand van de wedstrijd op het moment van de strafzaak in hoeverre speelt "drelgend verlies" of "vasthouden van de winst" een rol.

- plaats op het veld van de overtreding of strafzaak.

Overigens is, na het door ons geanalyseerde seizoen 80-81, de mogelijkheid aanwezig op de strafformulieren, via een voorgedrukte tekening van het speelveld, aan te geven waar de overtreding werd gekonstateerd. Daardoor zou duidelijker kunnen worden in hoeverre inderdaad een defensleve taktlek van Invloed is op het maken van overtredingen (Gabler, 1976; Bakker en Whit1ng, 1984).

\subsection{Praktiese betekenis resultaten}

De praktiese betekenis van de resultaten willen we beschrijven aan de hand van de algemene probleemstelling: "in hoeverre komen wedstrijden met strafzaken voor in het amateurvoetbal en welke faktoren zijn hierop van invloed; wat $z i j n$ de belangrijkste kenmerken van strafzaken en welke sanktles worden bij strafzaken toegepast".

\subsubsection{De algemene gituatie in het afdelingsvoetbal}

De allereerste vraag die wij na het hier beschreven onderzoek willen beantwoorden is of aantal en aard van de strafzaken een uitspraak wettigt over de ernst van de situatie in het afdelingsvoetbal.

Uiteraard speelt bif het antwoord op deze vraag een rol, hoe de vergelijking met resultaten van ander onderzoek is uitgevallen.

Ons is geen onderzoek bekend met ongeveer dezelfde populatie als onderwerp van onderzoek. Het betaalde voetbal levert 
over het algemeen meer strafzaken of wedstrijden met strafzaken op (0.a. Begerau, 1981; Lefebvre, 1974); het onderzoek van Volkamer (1971) met een populatie van amateurvoetbalwedstrijden resulteert in meer wedstrijden met $(64 \%)$ dan zonder strafzaak ( $36 \%)$.

In ons onderzoek is de verhouding wedstrijden met en zonder strafzaken 1:7; echter, als men tot de konklusie w11 komen dat de situatie in het afdelingsvoetbal derhalve meevalt dient een belangrijke vaststelling van het onderzoek te worden vermeld: de status van de scheidsrechter (onderscheld in officiële en niet-officiële scheidsrechters) drukt een belangrijk stempel op onze resultaten.

Niet-officiele scheidsrechters, die ruim $40 \%$ van het aantal wedstrijden leiden, maken relatief weinig officiële strafzaken aanhangig. De konklusie uit ons onderzoek hieromtrent luidt dat dit niet veroorzaakt wordt doordat niet-officlelen wedstrijden leiden die minder agressief zouden zijn maar dat zij door gebrek aan kennis en ervaring minder waarnemen en/ of durven te beoordelen. Met andere woorden door het aanwezig zijn van niet-officiele scheidsrechters, wordt het aantal strafzaken "gedrukt".

Niet alleen het aantal, ook de aard van de strafzaken levert de konklusie op dat scheidsrechters een belangrijke rol spelen in het afdelingsvoetbal. Vergeleken met $0 . a$. onderzoeken van Ekkers en Hoefnagels (1972) en Schmidt (1978) die beiden konstateren dat $10 \%$ van de strafzaken of overtredingen tegen de spelleiding is gericht, blijkt in ons onderzoek dit percentage 43 te zijn. Dit betekent dat zowel officielle als niet-officiele scheidsrechters in hoge mate bepalend zijn voor de aard van de strafzaken. Kortom, als men uitgaat van aantal en/of aard van de strafzaken in het afdelingsvoetbal en men antwoord wil geven op de situatie in de afdeling heeft dit antwoord meer betrekkIng op gedragingen van scheldsrechters dan op het feltellyke gedrag van spelers.

\subsubsection{Welke faktoren kunnen het voorkomen van strafzaken} belnvloeden?

Variabelen die bij een vergelifking tussen wedstrijden met en zonder strafzaken belangrijk bleken te $z i j n$ kunnen we globaal in een twee-deling opnemen. Allereerst de status van de scheidsrechter en vervolgens de variabelen die het wed- 
strijdbelang vertegenwoordigen. Het belang van deze variabelen is ook nog op een andere manier te presenteren.

Nagegaan kan worden in welke mate het percentage strafzaken toeneemt, naarmate we één voor één, te beginnen met de belangrijkste diskriminerende variabele, de vijf varlabelen status scheidsrechter (1), klassenivo (2), doelpuntenverschil (3), seizoensverloop (4) en afstand tussen de velden (5) in de beschrijving opnemen. In deze beschrijwing houden we ulteraard rekening met de gevonden samenhang van deze varlabelen met het voorkomen van strafzaken.

In tabel $9.1 \mathrm{z} 1 \mathrm{fn}$ de resultaten weergegeven.

Tabel 9.1.

Aandeel van 5 signiflkante diskriminerende variabelen in $\%$ wedstrijden met strafzaken $(\mathrm{N}=1750)$

$\%$ wedstr. met strafz.

- off. scheidsrechters

$20 \%$

- off. scheldsrechters

in le en $2 e$ klasse

- off. scheldsr. 1/2e klasse

klein doelpuntenverschil*

- off. scheidsr. 1/2e klasse

klein doelpuntenverschil

selzoensperiode 2

- off. scheldsr. 1/2e klasse klein doelp.versch., seiz. perlode 2 , kleine afstand tussen de velden

* kleln doelpuntenverschil betekent geén of 1 doelpunt verschil.

Bif wedstrljden geleld door officiele scheidsrechters in de eerste en tweede klasse, in de $2 \mathrm{e}$ seizoensperiode, tussen verenigingen met een kleine afstand tussen de velden, met als resultaat een klein doelpuntenversch 11 , komt in $38 \%$ van deze wedstrijden 'n strafzaak voor. 
De grote toename van het percentage wedstrijden met strafzak indien de variabele selzoensverloop wordt toegevoegd is wellicht te verklaren ult de keuze die bij deze presentatie van de variabele is gemaakt; in tegenstelling tot in de diskriminantanalyse is de $2 \mathrm{e}$ periode afgezet tegen de 4 andere perioden. Hoewel ook het thuis - ultspelen van invloed is op het krijgen van strafzaken kon deze varlabele door zijn specifieke aard, zijnde een strafzaakkenmerk, niet opgenomen worden in tabel 9.1 waarin de wedstrijd als analyse-eenheld wordt gebruikt.

Vooral de variabelen die het wedstrijdbelang vertegenwoordigen veroorzaken een grote kans op met name instrumentele overtredingen.

Naast de vergelijking van wedstrijden met en zonder strafzaken $z i j n$ we ook nagegaan, als strafzaken gegeven worden, welke partif de meeste kans hierop makkt.

Met name het uftspelen verhoogt de kans op strafzaken (55\% van alle strafzaken); daarbij moeten we tevens vermelden dat niet-offlciele scheidsrechters, $21 j$ worden door de thuisklub aangewezen, v66ral uitspelers bestraffen ( $80 \%)$. Overigens geldt voor zowel thuis- als ultklub dat het verliezen een belangrijke oorzaak is voor het opgelegd krijgen van strafzaken ... alleen, ultspelende klubs verliezen vaker!

Resumerend: de belangrijkste faktoren die het voorkomen van strafzaken in het afdelingsvoetbal belnvloeden $z i j n$ : officiele scheldsrechters, faktoren die het wedstrijdbelang vertegenwoordigen en het uitspelen.

9.2.3. Welke sankt1es kunnen spelers van scheldsrechter en tuchtkomissie verwachten?

De (1n)direkte vrije schop is een van de meest gebrulkte scheldsrechterlijke sanktie. Dit betekent dat door de daarop volgende spelonderbreking, de posities op het veld gekorrigeerd kunnen worden; van lets wat lonend werkt kan herhaling verwacht worden.

Uit ons onderzoek blifkt dat als een speler offlciel gestraft wordt:

- $80 \%$ van de scheidsrechterifjke sankties uit waarschuwingen bestaat,

- $38 \%$ van de sankties van de tuchtkommlssie resulteert in maksimaal een voorwaardelijke straf en 
- $34 \%$ van de tuchtrechtelijke sankties 1 wedstrijd schorsing inhoudt.

Met andere woorden over het algemeen worden lichte sankties toegepast; dit betekent in veel gevallen dat het nadeel van de te verwachten sanktie opweegt tegen het door de overtreding verkregen voordeel.

Eén van de voorwaarden om overtredingen te doen verminderen 1s, dat scheidsrechters konsekwent straffen.

Het blijkt dat officiele scheidsrechters in de $1 \mathrm{e}$ en $2 \mathrm{e}$ klasse meer overtredingen ten opzichte van spelers bestraffen; officielle scheidsrechters in de $3 \mathrm{e}$ en $4 \mathrm{e}$ klasse ên niet-officielen bestraffen verhoudingsgewijs meer overtredingen ten opzichte van hun leiderspositie. Daarnaast blijkt dat ntet-officielen vooral uitspelers bestraffen.

In het afdelingsvoetbal wordt, wanneer we de verschillende scheidsrechterskategorieën met elkaar vergelijken, niet konsekwent gestraft. Ons inziens heeft een niet konsekwente leiding een nadelige invloed op het gedrag van spelers. De tuchtkommissles blijken sankties van niet-officiëlen verhoudingsgewijs meer door onvoorwaardelijke straffen te laten volgen; zij hebben ons inziens meer oog voor het principe dat de gezagsdrager zoveel mogelijk "gedekt" moet worden dan dat $z i j$ de mogelijk niet objektieve leiding van de niet-officiele scheidsrechter ter diskussie stellen.

9.3. Beleidsaanbevelingen

9.3.1. Beleldsaanbevelingen vanuit ander onderzoek

Voordat we Ingaan op aanbevelingen die zouden moeten bijdragen tot beteugeling van agressie in de voetbalsport, willen we allereerst een opsomming geven van aanbevelingen van andere onderzoekers (al dan niet direkt verband houdend met de door hen gevonden resultaten).

Globaal zijn twee typen suggestles te onderscheiden: het eerste type houdt verband met het nemen van matregelen ten aanzien van verandering der spelregels; het tweede type legt de nadruk op opvoedkundige maatregelen.

1. Matregelen ten aanzien van veranderen spelregels zijn op zilch weer te splitsen in (zie ook Cauwels, 1977b) 
- strukturele maatregelen

- verandering spelregels om whst minder belangrijk te maken (Bauer, 1972; Lefebvre, 1974)

- repressieve maatregelen

- strengere sankties (Ekkers en Hoefnagels, 1972; Bauer, 1972)

- meer effektieve sankties, -om spelvoordeel bij maken van overtredingen te verminderen (bijvoorbeeld tijdstraffen): of sankties meer gericht op gevolg, dan op opzet (Ekkers en Hoefnagels, 1972)

- arbitrage:

* 2 scheidsrechters (Ekkers en Hoefnagels, 1972)

* tijdwaarnemers (Philipsen, 1983)

* onafhankel1jke derden langs de lijn (Wassing, 1978)

* betere psychologiese voorbereiding scheidsrechters (Aresu, 1979).

2. Opvoedkundige maatregelen

"Fair-play" moet belangr $1 j k$ worden, door sporters, trainers, bestuurders enz. duidelijk te maken dat agressief gedrag negatief is. De ene onderzoeker legt de nadruk op "leren" via scholleren (Rijsdorp, 1977, Schmidt, 1979) anderen leggen aksent op "fair-play" trainingen (Begerau 1980). Gabler (1976) legt nog een verband tussen de ernst van de overtreding en de mogelijkheid van preventieve matregelen; eenvoudige overtredingen zouden nopen tot een spelregelverandering; ernstige overtredingen elsen een persoonsverandering.

\subsubsection{Praktiese aanbevelingen}

Wanneer we uitgaan van onze onderzoeksresultaten willen we eerst stilstaan bij de faktoren die de kans op strafzaken vergroten.

De status van de scheidsrechter is een van de belangrijkste faktoren geweest die wedstrijden met strafzaken doet onderscheiden van wedstrijden zonder strafzaken; niet-officlele scheidsrechters melden nauwel1jks strafzaken.

Beperkte scheidsrechterskursussen, warin een basiskennis van spelregels wordt vereist zouden gegeven moeten worden aan personen die als lid van een vereniging potentiëel in aanmerking komen voor het leiden van wedstrijden; kennis van 
de spelregels kan leiden tot verlaging van de drempel sanktles tot offlciele strafzaak te benoemen. Sankties werken mér preventief dan het totaal afwezig zijn ervan. Omdat in het voetbal een groot blessurerisiko bestaat en een deel van de blessures te wijten is aan agresslef gedrag, zal stringentere toepassing van de spelregels (sankties) door de niet-officielen in de richting kunnen werken van een kleiner aantal blessures.

De voetbalbond kan, meer dan nu het geval is, een zodanig scheidsrechtersbeleid voeren dat het tekort aan officiele scheidsrechters niet alleen gericht is op het laagste klassenlvo. Met andere woorden door meer offlciele scheidsrechters in de laagste klassen aan te stellen wordt bereikt dat spelers in deze klassen, vaak aan het begin van hun spelerskarriëre, gekonfronteerd worden met een meer kwalitatieve leiding.

Een ervaring die positief kan doorwerken op het latere spelersgedrag...

Overigens blifkt dat de afdeling bij de toewijzing van officiele scheidsrechters weinig rekening houdt met de wedstrijdbelangen. Wedstrijden in de derde en vierde klasse geleld door offlcielen verschillen in wedstrijdkenmerken nauwelljks (verklaarde variantie $2 \%$ ) van wedstrijden in deze klassen geleld door nlet-offlctelen. Eén variabele is in deze analyse signifikant; officiellen worden meer aangesteld bij wedstrijden tussen kleine verenigingen.

Bij het selekteren van offlcielen of niet-officlelen zou men afgaande op onze resultaten rekening kunnen houden met het gebleken ekstra wedstrijdbelang van de $6 \mathrm{e} t / m 9 \mathrm{e}$ kompetitiezondag en met de gebleken belangrijkheid van een kleine afstand tussen de velden.

Bif deze laatste opmerking $z i j n$ we tevens aangeland bij faktoren die het wedstrijdbelang vertegenwoordigen en in ons onderzoek samen blijken te hangen met het voorkomen van vooral instrumentele overtredingen.

Beleidsaanbevelingen in dit kader liggen minder binnen prakthes bereik, omdat wedstrifdbelangen direkt verbonden zijn met een kompetitiesysteem warin "winnen" centraal staat. Het resultaat dat op een hoog klassenivo veel strafzaken voorkomen heeft met dit wedstrijdbelang te maken; immers in de hoogste klasse van de afdeling is promotie naar het KNVBamateurvoetbal mogelijk. 
Onze beleldsaanbevelingen in het kader van het wedstrifdbelang zijn niet direkt geènt op onze onderzoeksresultaten maar houden daar uiteraard wel verband mee. Mér dan bij de aanbevelingen over het scheidsrechtersbeleid zullen deze aanbevelingen meer het strafzakenbeleld als zodanig ter diskussie stellen.

Het voorkomen van met name instrumentele overtredingen bij belangrijke wedstrijden kent in het kader van preventleve matregelen twee mogelijkheden die met elkaar samenhangen:

1. Maatregelen betrekking hebbend op "mentaliteit"; ondersteund door

2. een effektiever werkend sanktlesysteem.

Ad. 1.:

U1t verschillende anekdotes blijkt dat ook in het "laagste" amateurvoetbal er een algemeen aanvaarde norm bestaat, inzake het overwegen overtredingen te begaan. De keuze tussen neerleggen en vasthouden (een anekdote uit hfdst. 2, blz. 46) is in dit opzicht frappant te noemen.

Ons inziens is dit voorbeeld in het voetbal een uiting van een algemeen aanvaarde norm; in dit kader heeft de topsport nog altijd een voorbeeldfunktie: De zogenaamde professionele overtreding is op alle voetbalnivos een normal verschijnsel. "Neerleggen is geweld dat niet als geweld wordt gezien. De speler krijgt er hoogstens een gele kaart voor, maar dit lang niet altijd. Het instrumentele geweld gat hoogtij vieren" (cit. Hoefnagels, 1986).

Deze nieuwe norm is voortgekomen uit de professlonalisering van het voetbal en de daarmee gepaard gaande ontwikkelde taktiese systemen.

Deze normen ontstonden of ontwikkelden zich bij personen die direkt of indirekt bij het voetbal betrokken waren; spelers (praktiese ultvoerders van de norm) krijgen opdracht van onder andere trainers en verenigingsbesturen. Daarnaast, of, hierarchies gezien, daarboven, bestaat dan nog het bestuur$11 \mathrm{jk}$ topnivo van de voetbalbond, in feite verantwoordelijk voor deze mentaliteit.

Maatregelen tegen een dergelijk normbesef dienen dan ook vanuit het bestuurlijk topnivo te worden verwezenlijkt. Uiteraard spelen grote financiele belangen in het betaalde voetbal een belangrijke rol en zijn debet aan deze normverschuiving. Echter dezelfde financiele belangen kunnen als argument gebruikt worden om aan te geven dat de steeds meer 
dalende publieke belangstelling ook financiele konsekwenties heef $t$.

Hoewel we beseffen dat deze verminderde publleke belangstelling ook andere oorzaken heeft, te denken valt o.a. aan veranderingen in de gezinsrekreatie, is de kwaliteit van het voetbal één oorzaak hiervan.

Met andere woorden op bestuurlijk topnivo zal men de voetbalwereld: tralners, besturen, spelers telkenmale moeten voorhouden dat verandering in mentaliteit, éen van de fundamentele vereisten is om voetbal voor spelers en publiek weer aantrekkel1jk te maken.

Wanneer men denkt aan praktlese aanbevelingen, suggereren we dat met name het jeugdvoetbal i.c. de opleiding, training van jeugdleider en jeugdscheidsrechter geschikt is on een betere mentalitelt te kweken; immers jeugdigen, aan het begin van een eventuele sportkarriere $z i j n$ waarschijnlijk nog het meest geschikt voor een dergelijke benadering.

\section{Ad. 2.: effektiviteit sanktiesysteem}

Naast mentaliteitsverbetering, ingegeven van bovenaf, wordt de struktuur van de voetbalsport bepaald door spelregels en sankties die mede verantwoordelijk zijn voor het voorkomen van agressief gedrag.

Hoewe1 verschillende onderzoekers pleiten voor een ander scheldsrechtersbeleid (bijvoorbeeld 2 scheidsrechters: Ekkers en Hoefnagels, 1972) is een dergelijke suggestie voor bijvoorbeeld het afdelingsvoetbal niet te realiseren; immers men zou dan voorbij gaan aan de praktlese situatie van een nog steeds toenemend tekort aan afdelingsscheidsrechters.

Sanktles zijn onderdeel van de spelrege1s.

Het is de vraag of de strafzaken die de bron van ons onderzoeksmateriaal hebben gevormd als zodanig een effektieve werking hebben.

In felte kan men stellen dat vooral vanuit het gezichtspunt van toepassing en werking van straffen het strafzakenbeleid zoals dat ten tijde van het onderzoek van kracht was niet effektlef was. De verandering, na het seizoen 80-81, betekent dat het zogenaamde boekingssysteem is ingevoerd. Een speler wordt "gewaarschuwd" tijdens een wedstrijd; naar aanlelding van de derde voor dezelfde speler geregistreerde waarschuwing binnen een termijn van eén jaar volgt een straf opgelegd door de tuchtkommissie. Bij ulthetveldzendingen volgt automaties een strafprocedure. 
Deze verandering in het strafzakenbeleid is ons inziens nog minder effektief: uit de leerpsychologie is bekend dat een straf het meest effektief is wanneer hij onmiddellijk volgt op het ongewenste gedrag, omdat de nadelige konsekwenties dan het sterkst aan het gedrag gekoppeld worden (Ekkers en Hoefnagels, 1972).

De eventuele straf wordt nu gerelateerd aan een drietal overtredingen in (meestal) drie verschillende wedstrijden; overtredingen die afhankelifk van de wedstrijdsituatie kwa aard en richting sterk kunnen verschillen. Met andere woorden een direkte relatie tussen overtreding en sanktie is niet meer aanwezig.

Stelt men de effektiviteit van sankties aan de orde dan gaan we ervan uit dat sankties zodanig moeten $z \mathbb{1 j n}$ dat het voordeel van de overtreding niet (meer) opweegt tegen het nadeel van de straf.

Uit het oogpunt van effektivitelt moet bij het strafzakenbeleid meer de nadruk worden gelegd op sankties tijdens de wedstrijd en niet, zoals nu het geval is, op uitgestelde sankties.

Een aantal mogelijkheden zijn hiervoor aan te geven:

- strengere sankties tijdens het spel; Ekkers en Hoefnagels (1972) en Kranenborg (1980b) pleiten voor het uitbreiden van de mogelijkheid van de strafschop; ook ernstige overtredingen buiten het strafschopgebled zouden met een strafschop beboet kunnen worden.

ook zou het mogelijk moeten zijn sankties aan te passen aan de situatie van de wedstrijd; bepaalde gedragingen die vaak plaatsvinden in het laatste kwartier van de wedstrijd zouden strenger gestraft kunnen worden (simuleren van blessures, tijdrekken); ook overtredingen zoals het neerleggen van spelers in de laatste minuten in een goede scorings-positie bij bijvoorbeeld een gelijke stand of eén doelpunt versch 1 .

- tijdstraffen, warbij spelers voor enige tijd op een strafbank worden geplaatst; een maatregel overigens die in het jeugdvoetbal reeds enige tijd toegepast wordt;

- een orientatie op het sanktlesysteem van andere sporten; uiteraard is feder spelregelsysteem geent op een specifleke tak van sport. Er zijn echter voorbeelden in andere sporten te vinden, zoals het systeem van de "persoonlijke foutentelling" in de basketbalsport die mogelijkerwijs ook in de voetbalsport tot hun recht kunnen komen. 
Hoewel we er min of meer van zijn ultgegaan dat dit soort sankties vooral het scala van instrumentele overtredingen zullen verminderen willen we tenslotte een belangrijke opmerking van Ekkers en Hoefnagels (1972) memoreren.

Reaktieve overtredingen die op zich geen funktie in het spel hebben $z i j n$ door hun veelal emotlonele karakter moeilijker te voorspellen. Ons onderzoeksverslag, gebruik makend van strukturele faktoren, heeft minder dan de instrumentele vorm deze reaktleve vorm van agressie kunnen verklaren.

In dit kader is het zinvol op te merken dat instrumentele en reaktleve agressie kunnen samenhangen. Volgens Ekkers en Hoefnagels (1972) is een belangrijk aspekt van instrumentele agressie dat het nieuwe frustratie-agressle in de hand werkt; met andere woorden reaktleve agressie kan een antwoord op instrumentele agressie zijn.

Daarom kan verandering van het sanktiesysteem in principe bedoeld om instrumentele agressie te verminderen, tevens betekenen dat deze verandering preventlef werkt ten aanzien van reaktięve agressie. 
HOOFDSTUK 10.

SAMENVATTING

In het kader van het Deelprojekt "de invloed van spelregels op spelbederf en spelverruwing" aan de Rijksuniversiteit Limburg is een van de onderzoeksvelden de voetbalsport. Met betrekking tot de voetbalsport is reeds een aantal onderzoeken verricht. In één hiervan (Kranenborg, 1980) werd de mening en houding van scheidsrechters over $0 . a$. taakopvatting en beoordelingsproblematiek gevraagd.

Gesuggereerd werd te trachten in ander, verder, onderzoek een relatie te leggen tussen deze scheldsrechterlijke meningen en de feitelijke gebeurtenissen op het veld.

Nadat hierover kontakt was opgenomen met de Koninklijke Nederlandse Voetbalbond afdeling Limburg, veranderde onze onderzoeksvraag. Immers, de Bond gunde ons een blik in de zogenaamde strafdossiers: leder dossier bevat alle door de scheidsrechter officieel aanhangig gemaakte straffen in eén wedstrijd. De inhoud van deze dossiers was dermate veelzijdig en interessant dat we besloten deze strafdossiers onderwerp van onderzoek te maken. Met andere woorden belangrijkste bron van ons onderzoek vormde de inhoud van deze strafdossiers in de KNVB-afdeling Limburg uit het seizoen 19801981 .

Naast de 1750 wedstrijden met strafrapporten, met in totaal 2678 individuele strafzaken, werden alle overige kompetitiewedstrijden in dit seizoen $(N=10.640)$ in het onderzoek opgenomen. Daardoor werd een vergelijking mogelijk tussen wedstrijden met en zonder strafzaken. Omdat van wedstrijden zonder strafzaken slechts een aantal objektieve kenmerken bekend is, was de keuze van de variabelen beperkt.

In het onderzoek zijn de volgende variabelen betrokken: klassenivo, kompetitiezondag, uitslag (aantal doelpunten, doelpuntenverschil, winst-ver1les), afstand tussen de ve1den, thuis-uitspelen, verenigingsgrootte, urbanisatiegraad en status scheidsrechter.

Deze laatste kategorle geeft het onderscheld weer tussen officiele en niet-officiele scheidsrechters; de laatste kategorie vult incidenteel het tekort aan scheldsrechters op; zij hebben dus geen officleel scheidsrechtersdiploma. 
In hoofdstuk 2 is aandacht geschonken aan het begrip agressle en de met dit begrip verwante teorieén.

Agressle is inhoudelijk moeilijk te definiëren. Ondanks de verscheidenheid aan meningen die hierover bestaat kan gesteld worden dat in leder geval drie elementen in het begrip zijn opgenomen: opzet, schade en in strijd met de norm.

Diskussle ontstaat dan wanneer één of meerdere elementen milnder duidelijk (aanwezlg) is.

Wat de agressieteorieen betreft is de instinktteorie, agressile is aangeboren en moet van tijd tot tijd ontladen worden, niet bruikbaar voor ons onderzoek. Deze kan immers geen antwoord geven op de probleemstelling waarbij een vergelijking wordt gemaakt tussen wedstrijden met en zonder strafzaken. De frustratie-agressieteorle (agressie kan ontstaan door blokkering van begonnen doelgericht gedrag) en de emotie-akt1vatieteorie (een grotere kans op agressie door een kombinatie van onaangename ervaringen en aktivatieverhoging) kunnen toegepast worden op de sportsituatie. Beide teorieen zijn overigens in hun werking niet strikt te scheiden. Gedrag dat met deze teorieern veelal in verband wordt gebracht is de reaktieve agressie.

Toepasbaar op de sportsituatie is eveneens de leerteorie: agresslef gedrag wordt verklaard door observatie, direkte ervaring en/of ervaren positieve of negatieve gevolgen (beloning of straf). Instrumentele agressie wordt veelal met deze teorie verbonden.

De sportsituatie, met name de voetbalsportsituatie schept een klimaat warin overtredingen tot het normale spelpatroon zi.jn gaan behoren.

Een aantal oorzaken is hiervoor aan te geven, oorzaken die verband houden met de struktuur van de sport bepaald door de spelregels: het toestaan van lichamelijk kontakt in sommige situaties; overtredingen moeten met opzet zijn begaan om strafbaar te $z i j n$, hetgeen interpretatieproblemen voor de scheidsrechter oplevert; het weinig effektief zijn van sankties en het in geringe mate toepassen van zware sankties.

Het belang van de scheidsrechterspositie is in de meeste onderzoeken teoreties weinig onderbouwd. De variabele status scheidsrechter is door ons gerelateerd aan aspekten van de rolteorie en van de cognitieve teorie.

De uitoefening van zijn rol wordt beinvloed door kennis van de spelregels en ervaring in het leiden van wedstrijden; dit heeft ons doen konkluderen dat niet-officiële scheidsrech- 
ters minder strafzaken aanhangig zullen maken. Het interne rolkonflikt van de niet-officiele scheidsrechter wordt nog versterkt door zijn binding met de thuisklub.

In hoofdstuk 3 zijn onderzoeken beschreven met de agressie op de voetbalvelden als onderwerp.

Ondanks allerlei verschillen in teoretiese uitgangspunten, operationalisering en populatie blijkt een aantal variabelen, werkend in dezelfde richting van belang te zijn bij het verklaren van agressief gedrag: een klein doelpuntenverschil, het uitspelen, verliezen, het belang van de wedstrijd en het middenveld of eigen speelhelft. Alleen de variabele klassenivo werkt, hoewel belangrijk als verklarende faktor, niet in alle onderzoeken in dezelfde richting.

Een bezwaar van veel onderzoeken is het niet terugkoppelen van resultaten aan de teoretiese uitgangspunten.

Voor ons onderzoek is getracht deze koppeling van variabele en teorie in hoofdstuk 4 tot stand te brengen.

Bij de samenhang tussen variabele en teorie spelen ons inziens vier faktoren hierin een bemiddelende, verbindende rol:

1. het wedstrijdbelang, uitgedrukt in variabelen als klassenivo, wedstrijdzondag, uitslag, afstand tussen de ve1den

2. het thuis - uitspelen

3. de sociale kontekst - verenigingsgrootte, urbanisatiegraad

4. arbitrage

In dit hoofdstuk zijn per variabele vervolgens hypothesen geformuleerd over de kans op strafzaken en over de aard (instrumenteel/reaktief) en richting (speler/scheidsrechter) van de overtreding die tot de strafzaak heeft geleid. Eveneens $z i j n$ veronderstellingen geopperd over de te verwachten sankties van respektievelijk officiele en niet-officiele scheidsrechters en van de tuchtkommisste.

In hoofdstuk 5 wordt met name antwoord gegeven op de probleemstelling "kunnen we bepaalde faktoren aanwijzen die het verschil verklaren tussen wedstrijden met en zonder strafzaken".

De verklaarde variantie bedraagt $15 \%$. 
Twee varlabelen spelen een belangrijke verklarende ro1, namelijk status scheidsrechter en klassenlvo: officiele scheldsrechters rapporteren meer strafzaken en op een hoog klassenivo komen meer strafzaken voor dan op een laag klassenivo. Naast deze variabelen blijken ook het begin van het selzoen, een geringe afstand tussen de velden en een klein doelpuntenverschi1 meer strafzaken op te leveren.

Dit heeft ons doen konkluderen dat vooral die variabelen een diskriminerend vermogen bezitten die het belang van de wedstrijd weergeven.

In hoofdstuk 6 is een beschrijving gegeven van een aantal strafzaakkenmerken. Allereerst is aandacht besteed aan onze operationalisering van de aard van de overtreding (verdeeld in instrumenteel en reaktief). Volgens deze werkwijze blijkt $60 \%$ van de overtredingen van instrumenteel te $z i j n$; wat de richting van de overtreding betreft is $57 \%$ van de overtredingen ten opzichte van de scheidsrechter begaan.

Het tifdstip van de strafzaak is in bijna $2 / 3$ van de geva1len gesitueerd in het laatste half uur van de wedstrijd. Van de scheidsrechterlijke sankties bestaat $80 \%$ uit waarschuwingen terwij1 drie kwart van alle straffen opgelegd door de tuchtkommissie, maksimaal één wedstrijd schorsing oplevert. Deze laatste bevinding heeft ons doen konkluderen dat in het afdellngsvoetbal nauwelijks gesproken kan worden van effektieve sanktionering.

Tenslotte is in dit hoofdstuk een antwoord gegeven op de probleemstelling "zijn er faktoren aan te wijzen die het verschil in aantal strafzaken per wedstrijd kunnen verklaren". De analyse levert slechts $2 \%$ verklaarde variantie op waaruit we de konklusie getrokken hebben dat er weinig versch11 bestaat tussen wedstrijden met éen of meerdere strafzaken.

In hoofdstuk 7 worden de veronderstellingen getoetst die per varlabele geformuleerd zijn over de aard en richting van de overtredingen, samengevat in de probleemstelling "kunnen we bepaalde faktoren aanwijzen die het verschil verklaren tussen wedstrijden met specifleke strafzaakkenmerken en wedstrijden zonder strafzaken"

De wedstrifden met strafzaken $z 1$ jn onderverdeeld in wedstrifdtypen, bepaald door de hierin voorkomende aard en richting van de overtredingen. 
In dit hoofdstuk zijn de varlabelen status scheidsrechter en klassenivo omgevormd tot én variabele. Deze variabele is onderverdeeld in officiele scheidsrechters in respektieve$11 j \mathrm{k}$ de eerste en tweede klasse en de derde en vierde klasse en niet-officiele scheidsrechters.

officielen in de eerste en tweede klasse bestraffen relatief vaak instrumentele overtredingen ten opzichte van spelers; officielen in de derde en vierde klasse en niet-officielen rapporteren verhoudingsgewijs meer instrumentele overtredingen ten opzichte van hun leiderspositie, hetgeen uitgelegd kan worden als een feitelijk dan wel gepercipieerd gebrek aan gezag.

Zonder de variabelen scheidsrechter en klassenivo zijn daarna de verschillende wedstrijdtypen vergeleken met wedstrijden zonder strafzaken.

Een eerste konklusie die uit deze analyses getrokken kan worden is dat analyses van wedstrijden met instrumentele overtredingen meer verklarende variantie opleveren dan wedstrijden met reaktieve overtredingen. Gekonkludeerd is dat reaktieve overtredingen door hun emotionele aard en het niet funktioneel zijn in het spel moellijk te voorspellen zijn. Bij vergelijking van wedstrijden met instrumentele overtredingen en wedstrijden zonder strafzaken blijkt vooral een klein doelpuntenverschil belangrijk te zijn bij de verklaarde variantie. Wedstrijden met reaktieve overtredingen komen vooral voor bij een kleine afstand tussen de velden, in de stad, en bij verlies van de uitspelende klub.

Tenslotte is in dit hoofdstuk aandacht besteed an de sankties van scheidsrechter en tuchtkommissie.

officielen hanteren vooral de waarschuwing als sanktie; niet-officielen sturen relatief meer personen uit het veld. opvallend is dat de tuchtkommissie bij niet-offlcielen waarschuwingen van deze kategorie meêr bestraft met een onvoorwaardelijke schorsing dan bij waarschuwingen gegeven door officiele scheidsrechters. Een verklaring hiervoor kan zijn dat de tuchtkommissie juist de niet-officielen in hun positie als gezagsdrager van de bond bevestigd wil zien.

In hoofdstuk 8 is aandacht besteed an het thuis- en ultspelen. Getoetst is de probleemstelling "welke partif maakt in een wedstrijd de meeste kans op strafzaken en hebben deze strafzaken dan spectfleke kenmerken". 
Over het algemeen blijkt het verliezen voor zowel thuis- als uitklub een belangrijke determinant voor het opgelegd krijgen van strafzaken. Naast frustratle kan hier ook een leerteoreties principe een rol spelen: de ervaring heeft geleerd dat thulsklubs vaker winnen - uitklubs passen een defensieve taktiek toe hetgeen de kans op overtredingen vergroot. Niet-officlelen bestraffen vooral uitspelers, hetgeen niet verwonderlijk is gezien hun binding met de thuisspelende vereniging.

Wat de samenhang betreft tussen thuis- en uitspelen is door ons verondersteld dat ultspelers meer reaktieve agressie zouden begaan. Echter niet verschillen in aard maar in de richting van de overtreding treden op: uitspelers worden meer bestraft met overtredingen ten opzichte van de scheidsrechters. Deze konklusle geldt voor zowel officiele als niet-officiele scheldsrechters. Vanult de spelers geredeneerd kan de scheldsrechter om welke reden dan ook als "thulsflulter" worden waargenomen en/of ervaren, hetgeen de kans op agressie ten opzlchte van zijn positie aannemelijk maakt.

Zowel bij de scheldsrechterlijke sanktie als de sanktie van de tuchtkommissie $z i j n$ geen grote verschillen aanwezig ten aanzien van thuis- of uitklub.

In hoofdstuk 9 tenslotte staan twee aspekten centraal: wat is de wetenschappelijke én praktiese betekenls van de gevonden resultaten.

Wat de wetenschappelifke betekenis betreft, is het in de praktijk vaak moellijk uit te maken of een variabele of kategorie van variabelen $z 1 \mathrm{ch}$ uit in instrumenteel of reaktief agressief gedrag. Deze twee vormen zijn nauw met elkaar verweven. Dit doet ons konkluderen dat de werking van de verschillende agressleteorleern niet altijd strikt te scheiden 18.

Hoewel we er ons van bewust $z 1 j n$ dat het gebrulk van rol- en cognitleve teorfeen vooral veroorzaakt wordt door de specifieke aard van ons onderzoeksmateriaal, namelijk de status van de scheldsrechter, kunnen deze teorieên ook in andere onderzoeken funktioneel zijn. Indien we dit onderzoek plaatsen tegen de achtergrond van andere onderzoeken dan stemmen de resultaten in veel gevallen overeen: érn van de voordelen van dit onderzoek is in leder geval geweest dat door de vergelljking met wedstrijden zonder strafzaken één belangrijke kontrolegroep is gehanteerd. 
Bij onze beleldsaambevelingen maken wij onderscheid in twee, overigens met elkaar samenhangende mogelijkheden:

1. maatregelen betrekking hebbend op "mentaliteit"; een ander normbesef waarin bijvoorbeeld "het neerleggen" niet meer als algemeen normaal wordt beschouwd. Deze matregelen dienen vanuit het bestuurlijk topnivo te worden verwezenlijkt en moeten ondersteund worden door

2. een effektiever werkend sanktiesysteem.

Een van de praktiese konklusies is, dat men zich in het kader van de toepassing en werking van straffen af kan vragen of de procedure met strafzaken zoals die in het geanalyseerde seizoen en daarna gehanteerd werd en is, effektief is. Gepleit wordt voor een beleid meer gericht op sankties tijdens de wedstrijd. Niet alleen kan hierdoor instrumentele, maar in samenhang met deze vorm ook reaktieve agressie meer effektief worden behandeld. 
Within the framework of the project "The influence of rules on gamesmanship and roughness of games" at the University of Limburg (UL), soccer is one of the fields of research. In a study by Kranenborg (1980), the opinions and attitudes of soccer-referees were asked about their interpretation of their task, the problems in making decisions.

It was suggested to relate these opinions of soccer-referees with what actually happens in the field, in other, further studies. After we had had contact with the K.N.V.B. (Royal Dutch Soccer Organization), our original aim to explore the above-mentioned relation changed, because the organization gave us the opportunity to have a look at the so-called disclplinary files; each file containing all offences in one match officially reported by the referee. The contents of these files was so varied and interesting that we decided to make these files the subject of our research. In other words, the most important source of our investigation was the contents of these disciplinary files.

The entire league, 12,400 matches of the season 1980-1981 of the senior amateur-soccer section in the province of Limburg was subjected to analysis.

Al1 disciplinary files $(N=1,750)$ were included. A file consists of, one or more offences, officially reported by the referee in one match. In these files 2,678 individual disciplinary cases were recorded.

Chapter one gives a description of the structure of the soccer-organization, deals with the conditions which may eventually create a disciplinary file and describes the population under study.

In our study the most important variables involved are: divistonlevel; date of the match; the score; distance between the grounds of the two teams playing; the number of teams the club comprises; degree of urbanization and status of the referee: official and unofficial referees. The last category is enlisted when the number of matches outnumber the avallable referees; the home-team, then, have to assign a person who has never taken a soccer-referee course. 
Chapter two deals with the definition of aggression and the relevant theories on this subject and places the role and position of the soccer-referee in a theoretical framework. It is generally accepted that we can speak of agression $1 f$ the three elements: intention, verbal or physical injury and violation of the norms, are unmistakably present. In contrast to the instinct-theory, the frustration-aggression theory and emotion-activation theory can be tested in the sportssituation. The so-called reactive (emotional) aggression is related to these theories.

The so-called instrumental aggression can also be related to learning theory, which, in principle can be suitably tested in the sportssituation.

Soccer provides a pattern in which offences are considered as normal; this pattern can be related to and explained by the structure of the game; the structure itself is determined by rules and sanctions. In many studies the referee position has little theoretical attention. We have related the status of the referee to aspects of the role-theory and of the cognitive theory. In exercising his role, the referee is influenced by knowledge of the soccer-rules and his experience as a referee.

Chapter three gives a review of other studies concerning aggression in soccer players and the referee-role.

In spite of differences in theoretical viewpoints, operationalization of aggression and in population, some variables seem to be important explaining aggression. These variables are: close scoring; playing away; losing the match and the importance of the match.

One disadvantage of many of these studies is the poor relation between results and theoretical starting-points.

This relation is explained and described in chapter four. Four factors can be considered as being mediatory in the relation variable-theory:

1. match importance;

2. playing at home or away;

3. social setting;

4. arbitration.

We formulated hypotheses (per variable) concerning the prevalence of disciplinary cases, the character (instrumental or reactive) and direction (player-referee) of offences resulting in disciplinary cases. 
In addition, hypotheses have been formulated about expected referee-sanctions and sanctions of the disciplinary commissions.

In chapter flve we started with a description of our variables in relation to the prevalence of disciplinary cases. One of the most salient results concerns the status of the referee. From the total number of league matches, $36 \%$ are supervised by an unofficlal referee.

However, in the disciplinary files, only $8 \%$ of the unofficial referees are involved.

A discriminant-analysis gives an answer to the problem-set "can we Indicate certain variables that explain the difference between matches with and without disciplinary cases". The most important discriminating variables are status of the referee and divisionlevel; the explained variance is $15 \%$.

Chapter six describes a few characteristics of a disciplinary case. Starting from our operationalization concerning the character of the offence, $60 \%$ of the offences can be considered as instrumental.

$57 \%$ of the offences represent a conflict between referee and player. Twothirds of the offences occur in the last half hour of the match. $80 \%$ of the referees dispatch the cases with a caution; threefourths of the sanctions of the disciplinary commisions consists, at most of suspension for one match.

In chapter seven we tested, per variable, hypotheses concerning character and direction of offences.

The matches with disciplinary files $(\mathrm{N}=1,750)$ are subdivided into types; these types are determined by the character and trend of offences. The variables of status of referee and divisionlevel are transformed into one variable. The most important results are:

- official referees in the first and second divisions penalize more instrumental offences against players; they use particularly caution as a sanction ( $85 \%)$.

- Official referees in the third and fourth divisions also use cautions ( $77 \%$ ); they penalize, according to the unofftcial referees more instrumental offences against the referee himself. 
- The unofficial ones tend to more severe sanctions. $52 \%$ of their sanctions are send-offs.

It is surprising that disciplinary commissions deal with sanctions given by unofficial referees more severely than with those given by the official ones.

In chapter elght we tested the problem worded as follows: "which team has the greatest chance to get a disciplinary sanction, and what specific characteristics, if any, do these cases have.

Losing the match seems to be an important factor to get involved in official sanctions.

Particularly the unofficial referees are biased towards the visiting team $(77 \%)$. Differences between home- and away teams are most manifest in the direction of the offence: away players are more often punished for offences against the referee himself.

In chapter nine, finally, two aspects are paramount: the scientific as well as the practical importance of the results.

As regards the scientific importance, we concluded that in many situations it is difficult to decide if a specific variable or category of variables expresses itself in instrumental or in reactively aggresive behaviour. These two types are closely related; this leads us to the conclusion that the operation of the different aggression theories cannot always be strictly separated.

Though we are aware of it that the use of role- and cognitive theories is mainly caused by the specific nature of our research material, namely the status of the referee (the possibility to distinguish between official and non-officlal referees), we suggest that these theorles can also be appropriate in other studies.

If we place this research against the background of other researches, we see that the results often agree: at any rate, one of the advantages of this research has been the possibility to compare matches with and without disciplinary files.

A very important practical conclusion is that, in the framework of the application and operation of sanctions, one may wonder if the procedure of disciplinary cases as adopted in the season analysed and afterwards is effective. 
A policy is urged that rather aims at sanctions during the match. By doing this, not only instrumental aggression, but, in connection with this, reactive aggression too can be treated more effectively. 


\section{LITERATUUR}

ALBRECHT D (1976) Was ist der Vorteil am Heimvortell. Leistungssport $2,138-141$.

ALBRECHT D en MUSAHL HP (1979a) Das Schiedsrichterphänomen ein Syndrom?

In: Albrecht D (ed) Fussballsport. Ergebnisse sportwissenschaftlicher Forschung. Berlijn, Bartels en Wernitz KG.

ALBRECHT D (1979b) Zur sportartspezifischen Aggression in Wettkampfspiel. Sportwissenschaft 9,78-91.

ALBRECHT D (1982) Empirische Agressionsforschung im Sport: Diagnose elner Diagnostik.

In: Pilz G et.al. Sport und Gewalt. Bericht der Projektgruppe "Sport und Gewalt" des Bundesinst1tuts für Sportwissenschaft. Schorndorf, Hofmann.

ARESU M, BUCARELl A A, MARONGIU P (1979) A preliminary investigation of the authoritarian tendencies in a group of sports referees. Int. J. Sp. Psy. 10, 42-51.

BAKKER FC en WHITING HTA (1984) Sportpsychologie. Alphen a.d. Rijn, Samson.

BANDURA A (1973) Agression, a social learning analysis. New Yersey, Prentice Hall Inc.

BANDURA A (1978) Social learning theory of agression. Journal of Comm. 28, 12-29.

BAUER D (1972) Anmerkungen zu Volkamers Untersuchung "Zur Agressivität in Konkurrenzorientierten sozlalen Systemen". Sportwissenschaft 2, 307-311.

BEGERAU R (1981) Aggressives Verhalten im Bundesliga-Fussbal. Sportwissenschaft 3, 318-329. 
BERKOWITZ L (1973) Sports, Competition and Agression. Physical Educator 30, 59-61.

BREDEMEIER B (1983) Athletic Agression: A moral concern. In: Goldstein JH (ed) Sports Violence. New York, Springer.

BRUG van der H (1980) Agressief gedrag van toeschouwers. Geneeskunde en Sport 13, 136-151.

BRUG van der $\mathrm{H}$ en MARSEILLE $M$ (1981) Spelbederf en overtredingen bij een voetbalwedstrijd. Geneeskunde en Sport 14, 117-120.

BURROUGHS (1972) Large Systems: Basis.

BUSS AH (1961) The Psychology of Aggression. New York/ London, Wiley.

CAUWELS A (1977a) Agressie in de sport. Determinanten van agresslef gedrag. Sporta $31,14-17$.

CAUWELS A (1977b) Agressie in de sport. Sporta 31, 48-54.

CAUWELS A (1977c) Geweld in de wereld, geweld in de sport. In: Cauwels A, Claes U, Braems $U$ en Becker de $A$, Geweld in de wereld, geweld in de sport. Verslag Sporta-congres, Leuven, Acco.

CAUWELS A (1977d) Theoriën over agressie.

In: Cauwe 1s A, Claes U, Braems $U$ en Becker de A, Geweld in de wereld, geweld in de sport. Verslag Sporta-congress, Leuven, Acco.

CENTRAAL BUREAU VOOR DE STATISTIEK (1980) Bevolking der gemeenten van Nederland op 1 januari 1980: tabe1 1 en 7. 's-Gravenhage, Staatsuitgeverij.

CICOUREL van A (1976) The social organization of Juvenile Justice. London.

COAKLEY JJ (1978) Sport in Society: issues and controversies. Saint Louis, Mosby. 
Ministerie van CRM (1977) Advies inzake spelverruwing.

Interdepartementale werkgroep voor aangelegenheden op het gebied van de lichamelijke vorming en sport. 's-Gravenhage, Staatsuitgeverij.

CovS (1984) "Zwartboek" over molestaties. Vlaardingen.

DOLLARD J, DOOB LW, MILLER NE, MOWRER OH and SEARS RR (1939) Frustration and Agression. New Haven, Yale University Press.

DOORN van JAA en LAMMERS CC (1973) Moderne Sociologie: een systematiese inleiding. Utrecht, Het Spectrum.

DROP MJ (1972) De geldigheld van de geregistreerde frequenties van afwijkend en zlektegedrag. Medisch-maatschappelijke voorzieningen als "cijfersproducerende" Instanties. Maandblad Geestelijke Volksgezondheid $27,2-11$.

DUNNING E (1976) The figurational dynamics of Modern Sport. In: Dunning $\mathrm{E}$ (ed) The Soclology of Sport. A Selection of Readings. London, Cass.

DUNNING E (1983) Social Bonding and Violence in Sport: A theoretical-empirical analysis.

In: Goldstein JH (ed) Sports Violence. New York, Springer.

ECKHOFF T (1971) Die Rolle des Vermittelnden, des Richtenden und des Anordnenden bei der Lösung von Konflikten. In: Hirsch $E$ und Rehbinder $M$ (hrsg) Studien und Materialen zur Rechtssozlologie. Opladen, West Deutscher Verlag.

EDWARDS I (1979) The Home-field Advantage. In: Goldstein JH (ed) Sports, Games and Play: Social and Psychological Viewpoints. Hillsdale, Lawrence Erlbaum Associates Inc.

EKKERS CL en HOEFNAGELS CP (1972) Agressie en straf op het voetbalveld. Meppel, Boom. 
EKKERS CL (1975) Sport en Agressie. Intermediair 11, 29-37.

EKKERS CL (1977) Aktivatie en agressie. Leiden, Dissertatie.

EKKERS CL (1980) Emotionerende en activerende invloeden op agressie in de sportsituatie. Geneeskunde en Sport $13,85-86$.

ELIAS N (1976) The Genesis of Sport as a sociological problem.

In: Dunning $\mathbb{E}$ (ed) The sociology of sport. A Selection of Readings. London, Cass.

FETZ F (1959) Der Platzvorteil und sein psychologischen Hintergrund. Leibesubungen und Lefbeserziehung $5,3-4$.

FRIS T (1972) Gelegenheidsagressie. Meppe1, Boom. Dissertatie.

FRANKENBERG R (1979) Fussbal1 als dörflicher Integrationsmechanismus.

In: Hopf W (hrsg) Fussbal1, Soziologie und Socialgeschichte einer popularen Sportart. Bensheim.

GABLER H (1976) Agressive Handlungen im Sport. Stuttgart, Hofmann.

GALEN van $W$ en DIEDERIKS $J$ (1984) Offences in Amateur Soccer; an analysis of 2723 cases.

In: Int.J.Sports Med 5, 214-215 Supplement.

GASKELL G en PEARTON R (1979) Agression and Sport.

In: Goldstelin $J_{H}$ (ed.) Sports, games and play. Hillsdale, Erlbaum.

GOOTJES HA en TOGT van der CR (1982) De scheidsrechterlijke beslissing. Amsterdam, Doctoraal scriptie.

GUTTMANN A (1981) Introduction.

In: Rigauer B, Sport and work. New York, Columbia University Press. 
HAZEWINKEL-SURINGA $D$ (1984) Inleiding tot de studie van het Nederlands strafrecht. Alphen a.d. RIjn, Tjeenk Willink.

HEISTERKAMP G (1975a) Psychologische Uberlegungen zum "Heim-

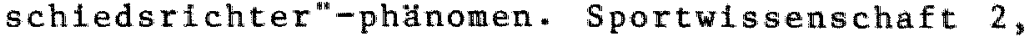
$185-190$.

HEISTERKAMP G (1975b) Die Psychodynamik von Kampfsplelen. Am Beispiel der Beziehung zwischen Schiedsrichtern un Zuschauern. Schorndorf, Hofmann.

HEISTERKAMP G (1977) Die Psychologie der Schiedsrichtersituation und ihre Bedeutung fur Spieler, Zuschauer und Trainer. Leistungssport $7,455-466$.

HEISTERKAMP G (1978) Psychologische Aspekte der Belastung von Schiedsrichtern. Leistungssport 8, 162-172.

HEISTERKAMP G (1979) Untersuchungen zur Objektivität von Schiedsrichterbeurteilungen durch Sportredakteure. Leistungssport 9, 384-393.

HEISTERKAMP G (1980) Warum gibt er ein Schledsrichterproblem. Leistungssport 10, 290-299.

HOEFNAGELS GP (1980) Beginselen van kriminologie, Deventer, Kluwer.

HOEFNAGELS GP (1986) Op het voetbalveld loont het geweldsde1fct. NRC-Handelsblad d.d. 23-6-1986.

HUETING JE (1978) Sport en geweld. Aantekeningen bij enkele recente pogingen ter beschrijving, verklaring en beheersing. Geneeskunde en Sport 11, 138-146.

KAHLER $R$ und VOLKAMER M (1982) Einstellung von Schulern zu Regeln und Normen im Sport.

In: Pilz $G$ et.al. Sport und Gewalt. Berlcht der Projektgruppe "Sport und Gewalt" des Bundesinstituts fur Sportwissenschaft. Schorndorf, Hofmann.

KLECKA W (1980) Discriminant analysis. Beverly Hills-London, Sage. 
KNVB (1980) Handleiding voor scheidsrechters. Veldvoetbal. Zelst.

KNVB (1981a) Jaarverslag 1980-1981. Afdeling Limburg.

KNVB (1981b) Jaarverslag 1980-1981. Afdeling Noord-Holland.

KNVB (1981c) Jaarverslag 1980-1981. Afde1ing Dordrecht.

KRANENBORG $\mathbb{N}$ (1980a) Sportbeoefening en blessures. Geneeskunde en Sport 13, 89-93.

KRANENBORG N (1980b) Scheidsrechteren, een moeilijke zaak. Enkele meningen en houdingen van voetbalscheidsrechters. Geneeskunde en Sport 13, 110-118.

KUHN W, MAIER $W$ und WIEPKING $W$ (1977) Untersuchung zur Problematik der Splelzeit im Fussball. Leistungssport $7,22-30$.

KUHN W und MAIER W (1978) Befträge zur Analyse des Fussbal1splels. Schorndorf, Hofmann.

LAMMERS CJ (1963) Het Konink1ijk instituut voor de marine. Assen, van Gorcum, Dissertatie.

LAMMERS CJ (1964) Uiterlijke samenhang en bindingskracht van de organisatie. Assen, van Gorcum.

LEFEBVRE LM en PASSER MW (1974) The effects of game location and importance on agression in teamsport. Int. J. Sp. Psy. 2, 102-110.

LEFEBVRE LM, LEITH LL, BREDEMEIER BB (1980) Modes for aggression assessment and control. A sportpsychological examination. Int. J. Sp. Psy. 11, 11-21.

LENK H (1972) Materialien zur Soziologie des Sportvereins. Ahrensburg, Czwalina.

MARK MM, BRYANT FB, LEHMAN DR (1983) Perceived injustice and sportsiviolence.

In: Goldstein JH (ed) Sports Violence. New York, Springer. 
McCARTY C (1976) Deviant Behavior. New York, MacMillan Publishing Co. Inc.

MCCRIMMON KR en TAYLOR RN (1976) Decision making and problem solving.

In: Dunette $M$ (ed) Handbook of industrial and organizational Psychology. Chicago, Rand McNally.

MIERMANS C (1955) Voetbal in Nederland. Assen, van Gorcum.

MIZRUICHI MS (1985) Local sports teams and celebration of community: a comparative analysis of the home advantage .

In: Sociological Quarterly 26, 507-518.

MULDER HF (1972) Agressie als sociaal-psychologisch probleem *

In: Verslag van de Twentse studiedagen voor de Lichame1ijke opvoeding, 20-33. Enschede.

MULIER W (1893) Athletiek en Voetbal. Haarlem, de Erven Loosjes.

PHILIPSEN H (1969) Afwezigheld wegens ziekte: een onderzoek naar oorzaken van verschillen in zlekteverzuim tussen 83 middelgrote bedrijven. Groningen, WoltersNoordhoff.

PHILIPSEN H (1976) Maatschappij en verslaving. Cahiers biowetenschappen en maatschappij 3, 25-31.

PHILIPSEN H (1980) De regeling van de speeltijd als oorzaak van spelbederf. Geneeskunde en Sport 13, 119-121.

PHILIPSEN H (1983) De scheidsrechter en de duur van het voetbalspe1.

In: Hueting JE en Brug v.d. H (uitg.) Sportwetenschappelijk onderzoek. Haarlem, de Vrieseborch.

PHILIPSEN H, JOOSTEN J en DIEDERIRS JPM (1984) Percelved Severity of offences in Professional Soccer. Int. J.Sports Med 5, 209-211 Supplement. 
PILZ GA (1974) Welchen Beltrag vermag die Sportpsychologie zur Aggressionforschung zu Leisten.

In: Schilling $G$ und Pilz GA (hrsg) Sportpsychologie wofür. Base1, Birkhäuser Verlag.

PILZ GA en TREBELS AH (1976) Agression und Konflikt im Sport. Ahrensburg, Czwalina.

PILZ GA (1979) Aggression und Gewalt im Fussbal1.

In: Albrecht $D$ (hrsg) Fussballsport. Ergebnisse sportwissenschaftlicher Forschung. Berlijn, Bartels en Wernitz KG.

PILZ GA (1980a) Entwicklungstrends expressiver und instrumenteller Gewalt im Sport (1). Sportunterricht 12, $457-464$.

PILZ GA (1980b) Sport und Gewa1t. Eine soziologische Analyse der Ursachen und Bedingungen agressiven Verhaltens in Sport.

In: Que111, Micheal (hrsg) Sport, Sozlologie und Erziehung. Berlijn, Bartels und Wernitz.

PILZ GA (1981) Efnstellungen zu sportartspezifischen agressiven Handlungen.

In: Kutsch Th en Wiswede G (hrsg) Sport und Gese11schaft: Die Kehrseite der Medaille. Königstein, Ts.

PILZ GA (1982) Körper1iche Gewalt von Sportlern.

In: Pilz GA (hrsg) Sport und Körperliche Gewalt. Reinbek, Rowolt Taschenbuch.

PRENNER K (1972) Agressivitat und Gewalt im Sport. Die Leibeserzlehung $21,340-344$.

RIDDER de $R$ (1980) Agressle in soclale interactie: waarneming en reactie. Tillburg Dissertatie.

RIGAUER B (1981) Sport and Work. New York, Columbia University Press.

RUSSELL GW (1983) Psychological Issues in Sports Agression. In: Goldstein $\pi H$ (ed) Sports Violence. New York, Springer. 
RIJSDORP K (1977) Sport en maatschappij. Alphen a.d. Rijn, Samson.

SCHILLING G (1976) L'agressivité, la violence et le sport. Proceedings Int. Congr. Phys. Activity Sclences. Quebec, 329-336.

SCHMIDT W (1.977) Aggressives Verhalten im Fussball. Systematische Beobachtung lernbehinderter Sonderschilern im Kleinfeldfussbal1. Sportunterricht $8,269-274$.

SCHMIDT W (1978) Agression und Sport. Ahrensburg, Czwalina.

SCHMIDT W (1979) Gruppendynamische Aspekte aggressiven Verhaltens im Sportspiel. Gruppendynamik 10, 28-33.

SCHMIDT W (1980) Sportliche Betätigung und agressives Verhalten. Problemaufriss und Forschungsperspektiven. Sportwilssenschaft $10,46-56$.

SCHWARTZ $H$ en BARSKY SF (1977) The Home Advantage. Socla1 Forces 3, 641-661.

SEGERS JHG en STOUTHARD Ph.C (1963) Analyse door middel van opeenvolgende contrasterende groepen. Sociale wetenschappen $3,221-224$.

SEGERS JHG (1964) De contrastgroepen-methode. Sociale wetenschappen $7,194-225$.

SIMONS D (1972) Zur Theorie der Aggression im Sport. Die Leibeserziehung $21,415-419$.

SPRENGER J (1974) Zum Problem der Agressionen im Sport. Ein kritischer Uberblick zum gegenwärtigen Forschungsstand. Sportwissenschaft 4, 231-257.

STOKVIS R (1979) Strijd over sport: organisatorische en ideologische ontwikkelingen. Deventer, van Loghum Slaterus. 
SYKES GM, MATZA $D$ (1968) On neutralizing delinguent self1mages.

In: Rubington $E$ (ed) The interactionist perspect1ve. New York, MacMi1lan.

TABACHNICK BG and FIDELL LS (1983) Using Multivariate Statistics. New York, Harper and Row.

TOPOGRAFISCHE DIENST (1980) Catalogus van kaarten.

* Voor onderzoek gebruik gemaakt van kaarten schaal $1: 25.000$ provincie Limburg.

VARCA Ph.E (1980) An analysis of Home and Away Game Performance of male college basketball teams. Journal of Sport Psychology 2, 245-257.

VAZ EW (1979) Institutionalized Rule Violation and Control in organized Minor League Hockey. Can. J. Appl. Sportssclence $4,83-90$.

VERCRUIJSSE E (1970) Het ontwerpen van een sociologisch onderzoek. Assen, van Gorcum.

VINNAI GL (1970) Ideologie des Fussbal1sports. Hannover. Europaischer Verlagsanstalt GmbH.

VoIGT HF (1982) Die Struktur von Sportdisziplinen als Indikator fur Kommunikationsprobleme und Konflikte.

In: Pilz $G$ et.al. Sport und gewalt. Berichte der Projektgruppe "Sport und Gewalt" des Bundesinstituts für Sportwissenschaft. Schorndorf, Hofmann.

VOLKAMER M (1971) Zur Aggressivitat in konkurrenzorientierten sozialen Systemen. Sportwlssenschaft 1,33-64.

VOLKAMER M (1972a) Sport als aggressives Verhalten aggressives Verhalten im Sport. Leibeserziehung 21, 409-415.

VOLKAMER M (1972b) Experimente in der Sportpsychologie. Schorndorf, Hofinann. 
WASSING A (1978) Het tuchtrecht van het publiek-voetbal. Deventer, kluwer.

WASSING A (1981) Het relatieve karakter van de beslissingen van de scheidsrechter in het betaalde voetbal.

In: Bins AJ et a1, Beginselen: opstellen over strafrecht aangeboden aan GE Mulder, Arnhem Gouda Quint.

MINISTERIE VAN WELZIJN, VOLKSGEZONDHEID EN CULTUUR (1985) Aard en omvang van sportongevallen en sportblessures. Leidschendam.

WIEGMAN o et.a1. (1982) Agressie en criminaliteit. Deventer, Kluwer.

WOLF PG (1962) Die Kriminalität bei Fussballspielen. Eine kriminologische Untersuchung. Lahr/Baden, Kaufmann.

ZAJONC RB (1968) Cognitive theories in social psychology. In: Lindzey $E$, Aronson $E$ (eds) The Handbook of Social Psychology. Austin.

ZIJDERVELD AC (1973) De theorie van het symbollsch interactionisme. Meppel, Boom. 
197

BIJLAGEN 
Bijlage 1.1. (Bron: KNVB, 1980)

Overtredingen die een directe vrije schop en eventueel een strafschop tengevolge hebben (A), en overtredingen die bestraft worden met een indirecte vrije schop (B).

Een speler moet worden bestraft met het toekennen van een directe vrije schop Indien hij opzettelijk één van de 9 hieronder volgende overtredingen begat:

a. een tegenspeler trapt of poogt te trappen,

b. een tegenstander doet vallen, waronder is te verstaan het laten vallen of pogen te laten vallen met behulp van de benen of door voor of achter hem te bukken,

c. springt naar een tegenstander,

d. een tegenstander op een ruwe of gevaarlijke wijze aanvalt,

e. een tegenstander van achteren aanvalt, tenzij deze hem met opzet hindert,

f. een tegenstander slaat of poogt te slaan,

$g$ * een tegenstander vasthoudt,

h. een tegenstander duwt,

1. de bal met de hand speelt, d.i. de bal met hand of arm draagt of voortbeweegt (dit slaat niet op de doelverdediger, wanneer deze zich in zijn strafschopgebied bevind $t$ ). 
Bijlage 1.1. (vervolg)

B.

Een speler moet worden bestraft met het toekennen van een indirecte vrije schop indien hij een van de volgende vijf overtredingen begaat:

1. speelt op een wijze die door de scheidsrechter gevaarlijk wordt geacht, bijv. poogt de bal te trappen, indien deze in het bezit is van de doelverdediger;

2. eerlijk aanvalt (dat is met de schouder) indien de bal zich niet bevindt binnen het speelberelk van de betrokken spelers en zij zeker niet proberen deze te spelen;

3. opzettelijk een tegenstander hindert, terwijl hij zelf de bal niet speelt, d.w.z. tussen een tegenstander en de bal doorloopt met de bedoeling daarmede zijn tegenstander te hinderen of zijn lichaam plaatst tussen de bal en de tegenstander;

4. de doelverdediger aanvalt, behalve wanneer deze:

a. de bal in zijn bezit heeft,

b. een tegenstander hindert,

c. zich buiten zijn doelgebied bevindt;

5. wanneer hij als doelverdediger:

a. meer dan 4 passen doet, terwijl hij de bal draagt, laat stuiten of deze weer in de lucht werpt en dan vangt, zonder de bal in het spel te brengen, na die vierde pas, zodat deze door een andere speler kan worden gespeeld, of

b. een taktiek toepast, die naar het oordeel van de scheidsrechter alleen maar ten doel heeft het spe1 op te houden en daardoor tijd te rekken en zodoende $z i j n$ partif op onsportieve wifze te bevoordelen. 


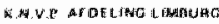

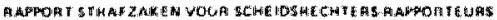

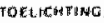

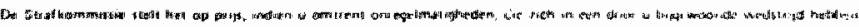
varor

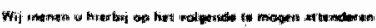

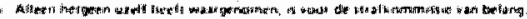

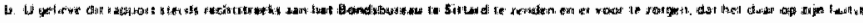

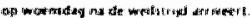

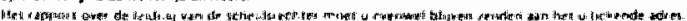

6. Whi wh

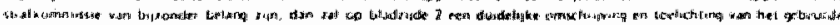

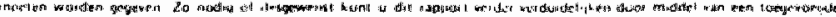
thaits!

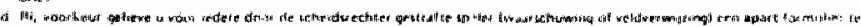

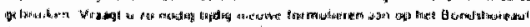

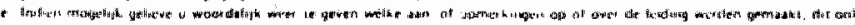

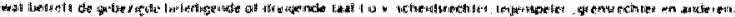

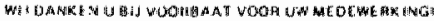

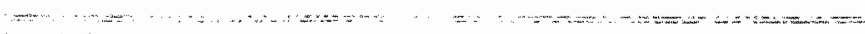

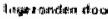

H.w.

Aden:

Tei:

Wt:d?:1 ąd

t4d.

Cowlank: door:

WAAB

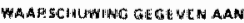

Lition. wim.

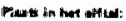

Uirssing:

UIT HIET VELO GE RONOE

$\therefore=$

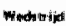

d.d.

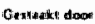

Plath un hall athtul.

Uitala:

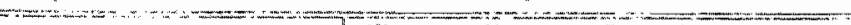

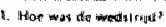

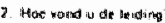

3 Hig was thet opleorlem wan

(dx) spentecthtet it

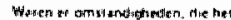

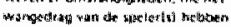

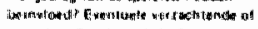

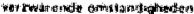

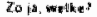

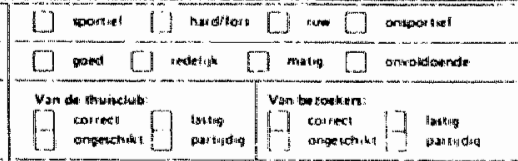


Bijlage 1.2.

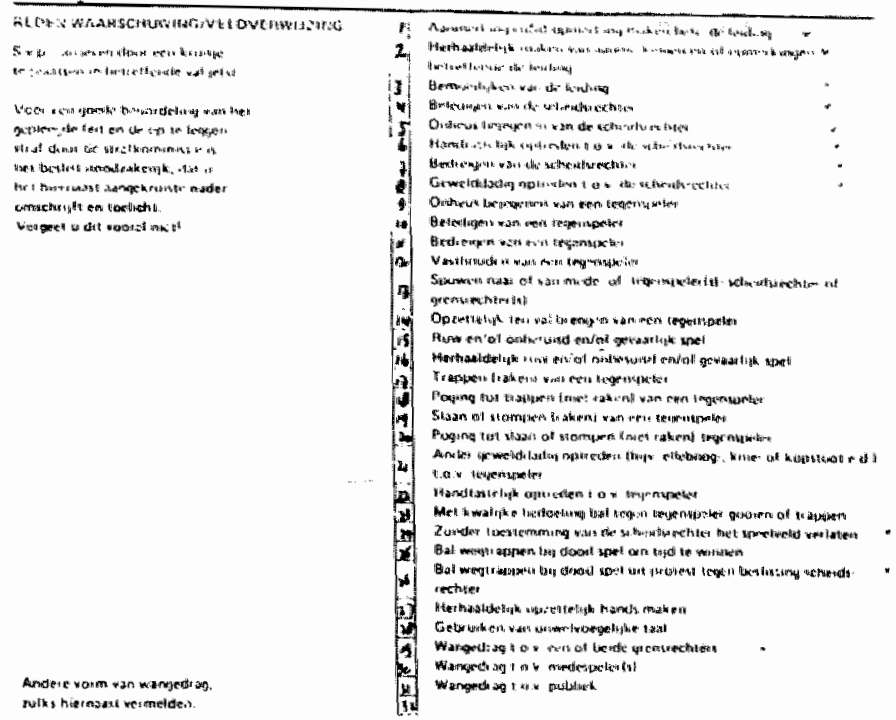

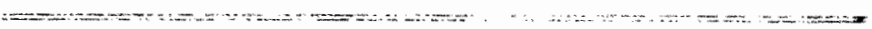

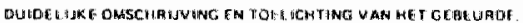




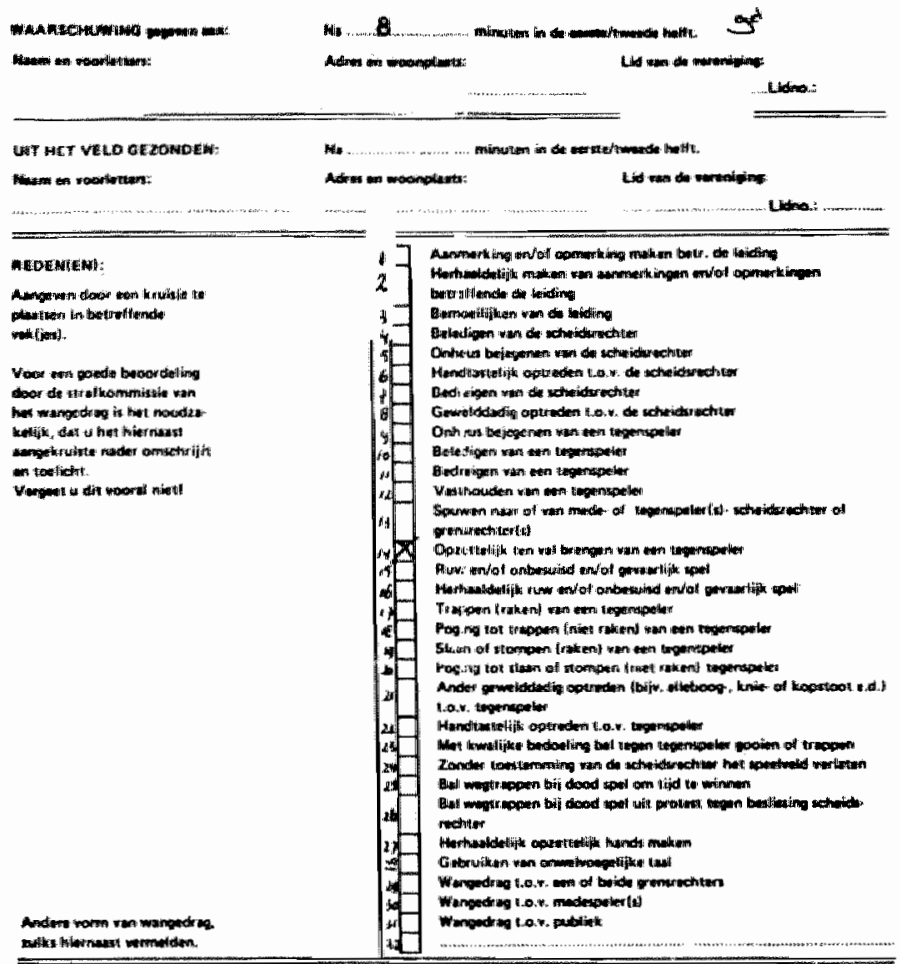

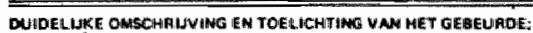

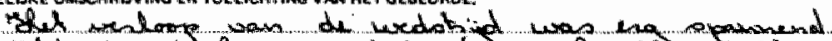

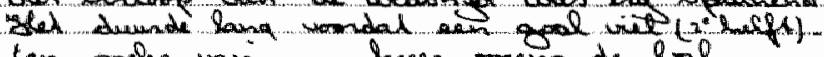

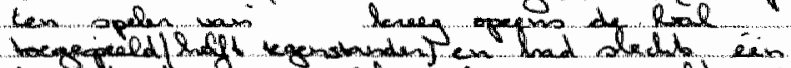

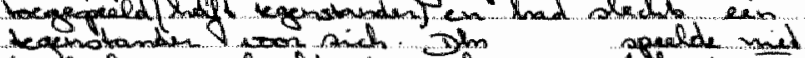

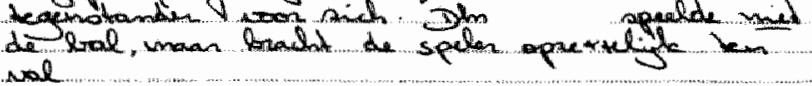

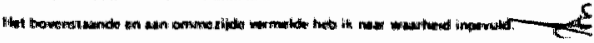




\section{Tolltimas:}

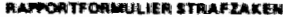

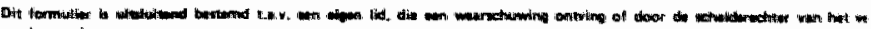
wation.

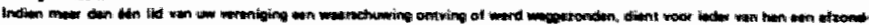

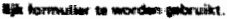

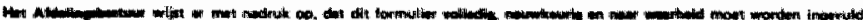

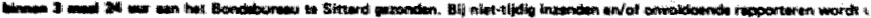
moniming

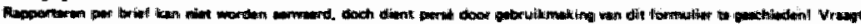

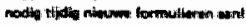

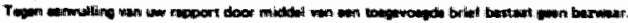

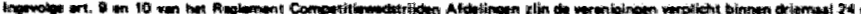

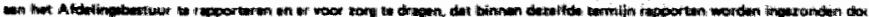

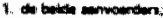

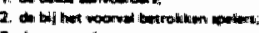

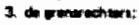

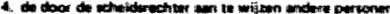

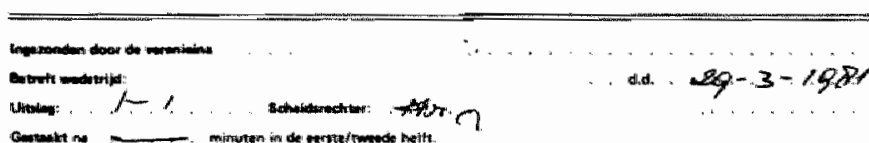

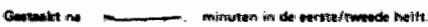
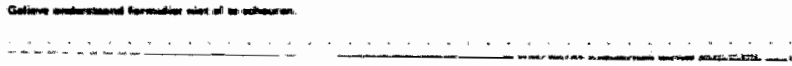

\begin{tabular}{|c|c|}
\hline Wirstom 19 & \\
\hline 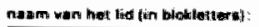 & pab. dratum: \\
\hline \multicolumn{2}{|l|}{ 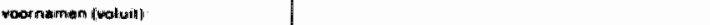 } \\
\hline \multicolumn{2}{|l|}{ edres: wo woonsplents: } \\
\hline hudidupe vesteniging: & Hidin: \\
\hline \multicolumn{2}{|c|}{ 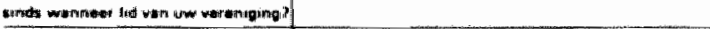 } \\
\hline \multicolumn{2}{|l|}{ 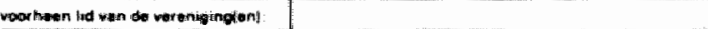 } \\
\hline \multicolumn{2}{|c|}{ 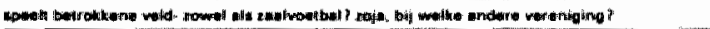 } \\
\hline \multicolumn{2}{|c|}{ 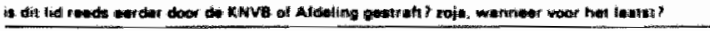 } \\
\hline \multicolumn{2}{|c|}{ 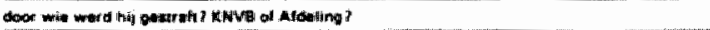 } \\
\hline \multicolumn{2}{|c|}{ 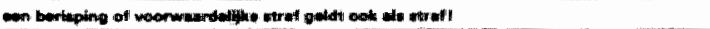 } \\
\hline 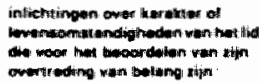 & \\
\hline
\end{tabular}


B1jlage 1.3.

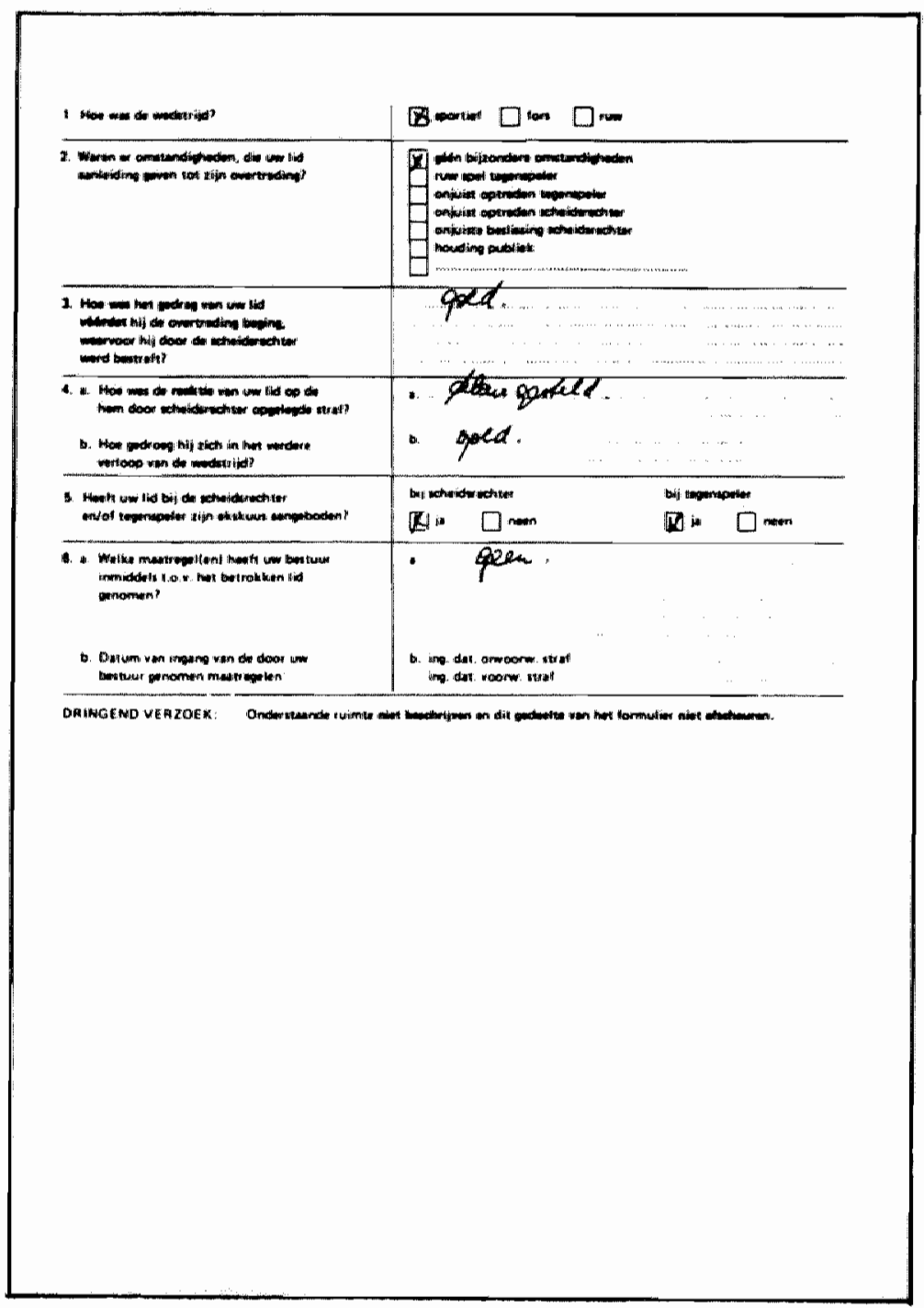




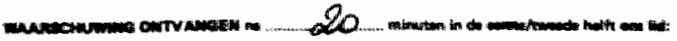

-10

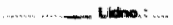

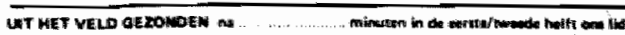

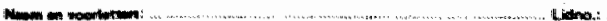

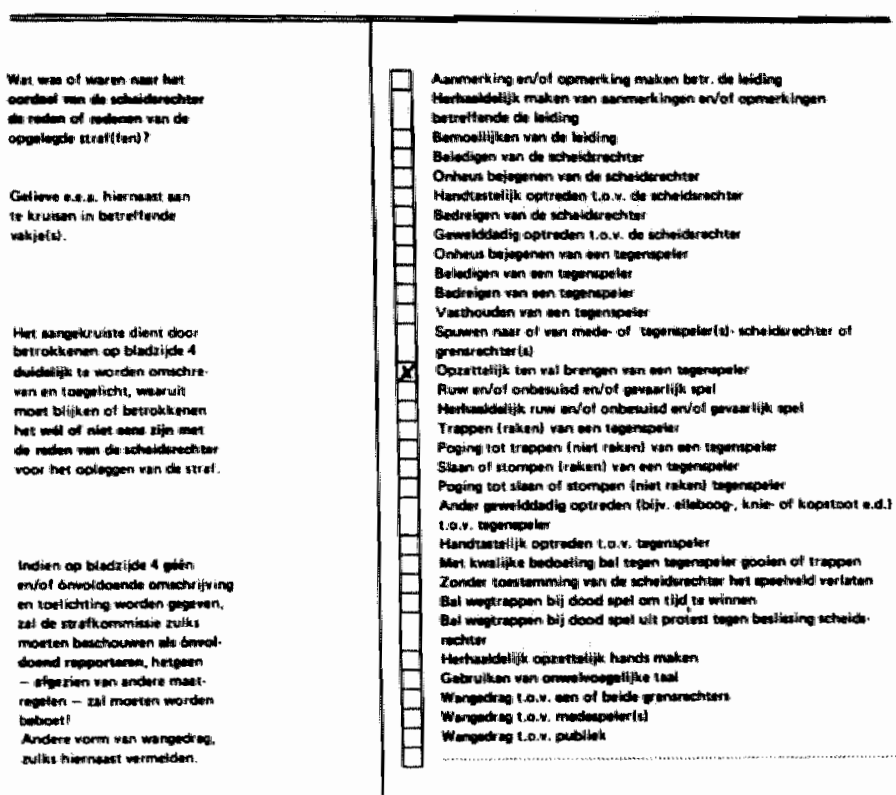




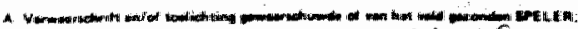

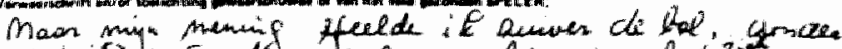

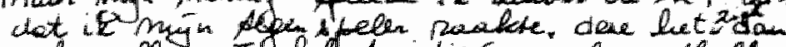

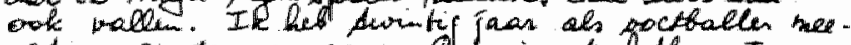

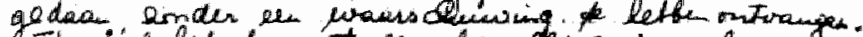

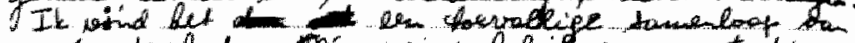

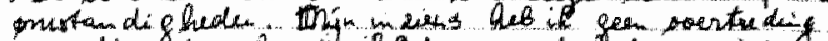

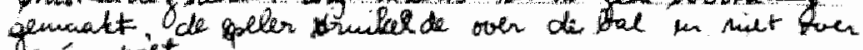
Wingun voict.

Numas in wintion:

$$
r
$$

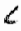

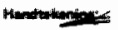

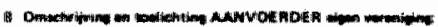

On re speler speelde dwiditg de bal. endat aju

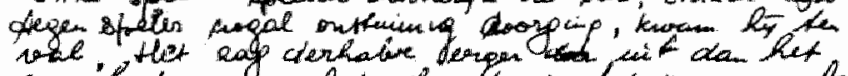

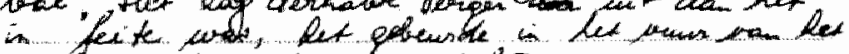

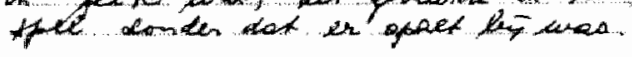

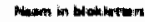

Lintros:

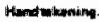

3

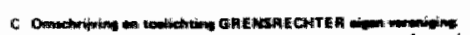

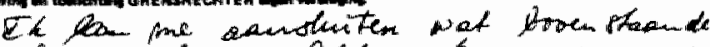

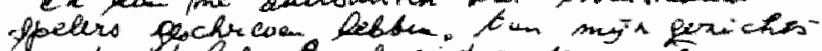

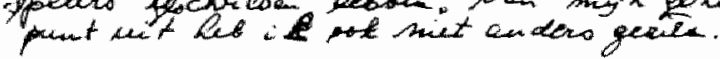


Bijlage 1.4.

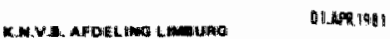

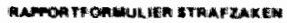

THEA HeNT ing:

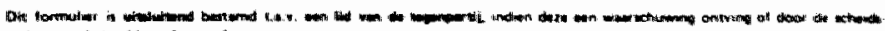

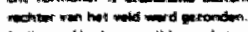

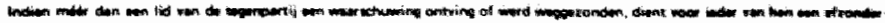

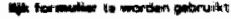

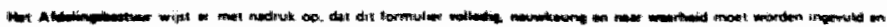

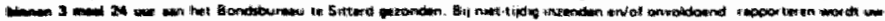

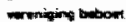

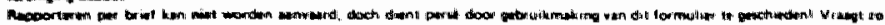

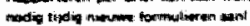

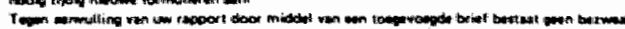

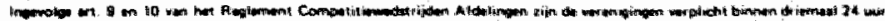

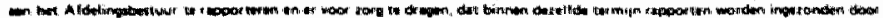

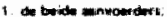

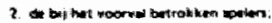

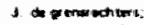

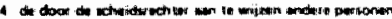

\section{4.}

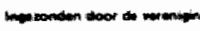

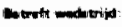

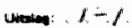

a.d. $x y+3-19 d x$

antemat nat

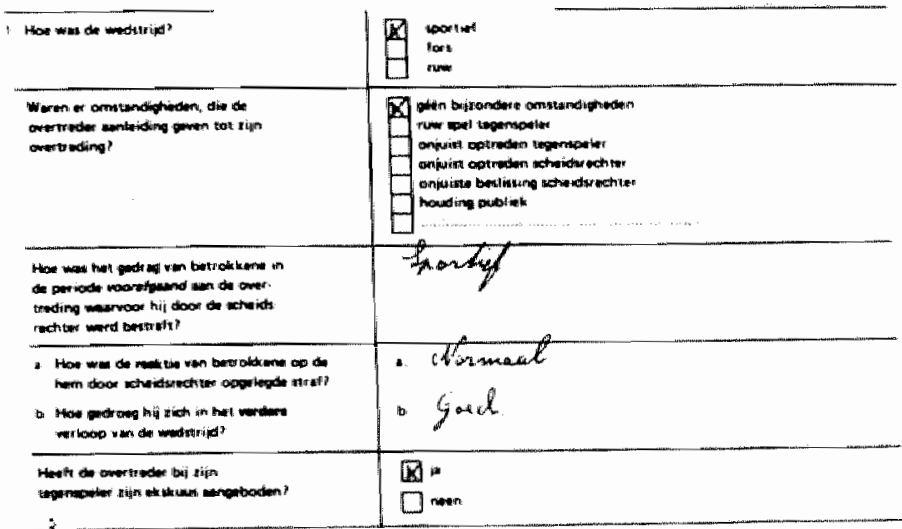




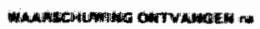

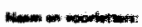

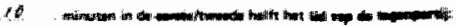

Lition.

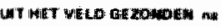

Hom and

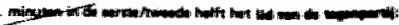
Whine:

What wat wat wat

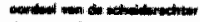

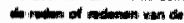

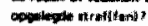

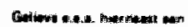

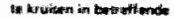
witimet.

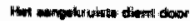

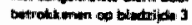

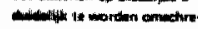

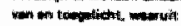

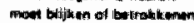

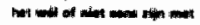
hel ment

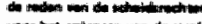

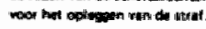

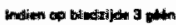

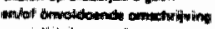

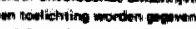

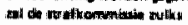

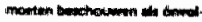

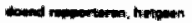

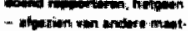

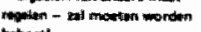
buthom!

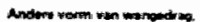

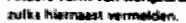

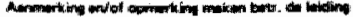

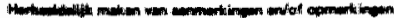

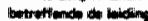

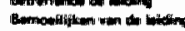

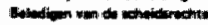

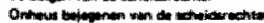

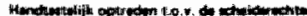

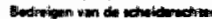

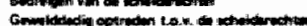

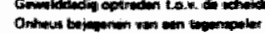

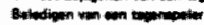

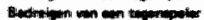

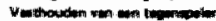

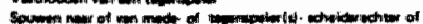

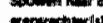

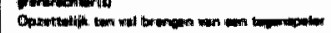

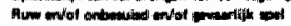

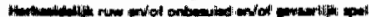

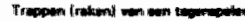

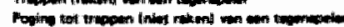

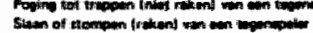

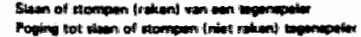

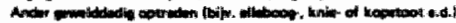

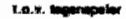

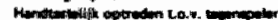

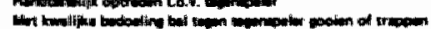

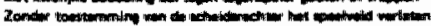

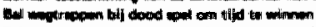

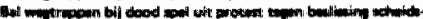

nnotiater

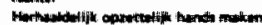

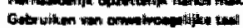

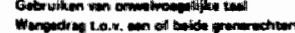

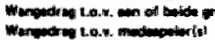

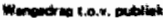


Bijlage 1.4.

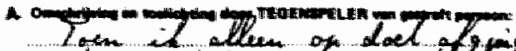

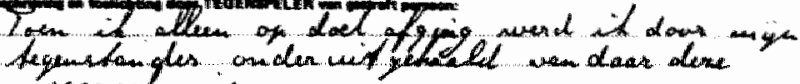

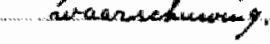

$$
\text { ih }
$$

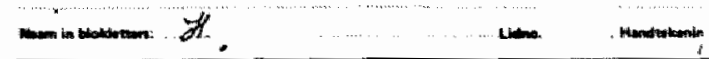

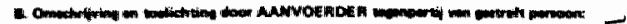

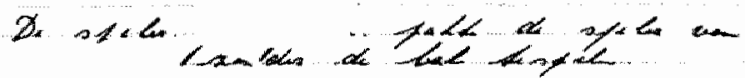

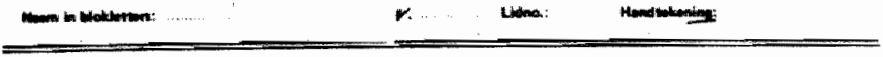

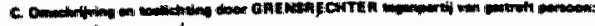

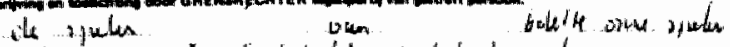

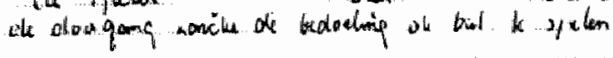


Tabe1 5.1A.

Wedstr1jden met en zonder strafzaak naar klassenivo $(N=12.391)$.

Klassenivo

met
strafzaken
$\%$

Wedstrijden

zonder

totaal

strafzaken

$\%$

le klasse $(N=12)$

31

20

69

1.562

80

3.147

9

91

3.057

$3 e$ klasse ( $N=24)$

93

4.625

$(1.750)$

$(10.641)$

12.391

$\mathrm{Tc}=0.17$

Tabel 5.2A.

Wedstrijden met en zonder strafzaak naar seizoensverloop $(\mathrm{N}=12.391)$.

Seizoensverloop

met

strafzaken

$\%$

13

19

15

16

14

14

9
Wedstrijden

zonder

strafzaken

$\%$

totaal

(N)

87

81

85

84

86

86

91
1.701

1.684

2.154

1.503

1.599

2.025

1.725

(1.750)

(10.641) 12.391

$\mathrm{Tc}=.04$ 
Tabe1 5.3A.

Wedstrijden met en zonder strafzaak naar rangverschil $(\mathrm{N}=12.391)$.

Rangverschil

met
strafzaak
$\%$

Wedstrijden

zonder

strafzaak

$\%$

totaal

(N)

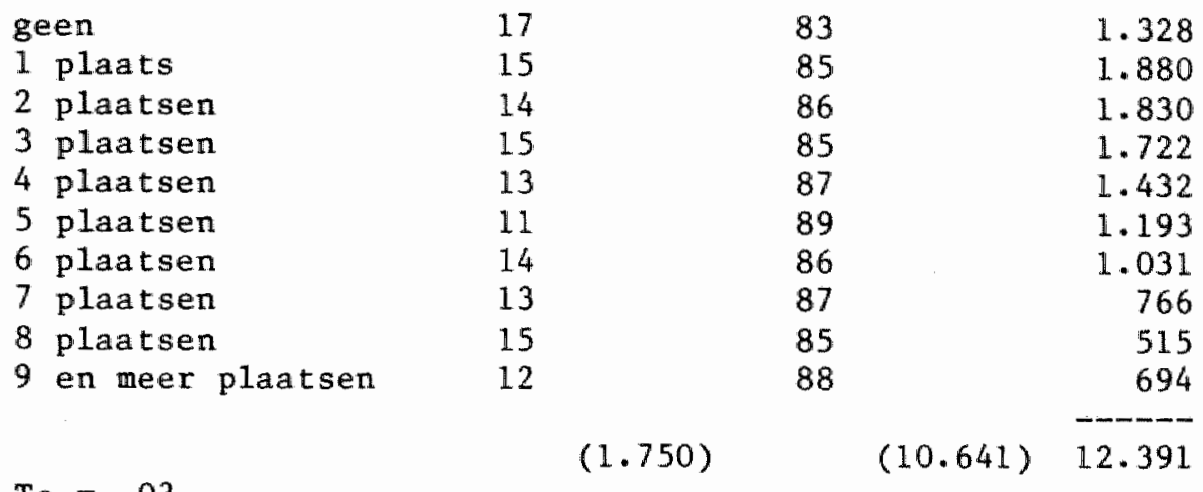

$T c=.03$

Tabe1 5.4A.

Wedstrijden met en zonder strafzaak naar afstand tussen de voetbalvelden $(\mathrm{N}=12.391)$

Afstand tussen de velden

$$
\begin{aligned}
& \text { met } \\
& \text { strafzaak } \\
& \%
\end{aligned}
$$

15

14

14

14

13
Wedstrijden

zonder

strafzaak

$\%$

totaa 1

(N)

85

2.940

86

4.510

86

2.506

86

87

1.586

849
$(1.750)$
$(10.641)$
12.391

$\mathrm{Tc}=.007 \mathrm{n} \cdot \mathrm{s}$. 
Tabe1 5.5A.

Wedstr1Jden met en zonder strafzaak naar totaal aanta 1 doelpunten $(N=12.391)$

Aanta1 doelpunten

$$
\begin{aligned}
& \text { met } \\
& \text { strafzaak } \\
& \%
\end{aligned}
$$

$\begin{array}{llr}\text { geen } & \text { doelpunten } & 17 \\ 1 & \text { doelpunt } & 19 \\ 2 & \text { doelpunten } & 16 \\ 3 & \text { doelpunten } & 16 \\ 4 & \text { doelpunten } & 14 \\ 5 & \text { doelpunten } & 14 \\ 6 & \text { doelpunten } & 13 \\ 7 & \text { doelpunten } & 10 \\ 8 & \text { doelpunten(en meer) } & 7\end{array}$

$\mathrm{Tc}=.06$
Wedstrijden zonder strafzaak $\%$ totaal

83 424

81 1.048 1.787 1.993 2.090 1.633 1.176 1.331 909
$(1.750)$
$(10.641)$

Tabe1 5.6A.

Wedstrijden met en zonder strafzaak naar doelpuntenverschil $(\mathrm{N}=12.293)$.

Doe1puntenversch11
met
strafzaken $\%$

Wedstrijden

zonder

strafzaken

$\%$

totaa 1

(N)

82

2.183

83

3.326

86

2.408

89

4.376

$T c=.06$
(1.745)
(10.548) 12.293 
Tabe1 5.12 .

Correlatie-matrix onafhankelijke variabelen weergegeven coëfficiënten signifikant bif $p<.05$

$\begin{array}{llllllllll}1 & 2 & 3 & 4 & 5 & 6 & 7 & 8 & 9 & 10\end{array}$

1. klassenivo -

2. seizoensverloop

3. rangversch..$- .02 \quad .14 \quad$

4. afstand $-.10 \quad .03-$

5. aantal $\begin{array}{llll}\text { doelpunten } & .17 & .08\end{array}$

6. doelpuntenverschil

.13

.11

.54

7. winst/ verlies

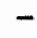

8. ver.grootte $.08-.02$ $-.04-.01 \quad-$

9. urbanisatie- graad
.03
$-.32 \quad .04$
$.08 \quad-$

10. status

scheldsr. $\quad .52-.02$

$.11 \quad .07-.02 \quad .11$ 


\section{Bijlage 5.13A}

De variabele afstand $1 \mathrm{~s}$ in de regio $1 \mathrm{t} / \mathrm{m} 3$ identiek gekodeerd (tot $4 \mathrm{~km}=1 ; 4$ tot $8 \mathrm{~km}=2 ; 8$ tot $12 \mathrm{~km}=3 ; 12$ tot $17 \mathrm{~km}=4 ; \quad 17 \mathrm{~km}=5$ ).

In de reg10's 4 en $5 \mathrm{zljn}$ in verband met de kleinere afstanden de kategorleën 4 en 5 samengenomen tot éen kategorie.

De variabele verenigingsgrootte is in de regio's 1,2 en 5 identiek gekodeerd $(<4$ elftallen $=1 ;>4$ elftallen $=2$ ). Gezien de kleine verenigingsgrootte in regio 3 en 4 is de kodering in deze regio's $<3$ elftallen $=1 ;>3$ elftallen = $2)$. Dok de variabele urbanisatiegraad is niet in alle reglo's gelifk onderverdeeld. Wanneer we bifvoorbeeld een vergelijking maken tussen de regio's 1 en 3 dan is het niet mogelijk een en dezelfde indeling aan te houden. Dit probleem hebben we ondervangen door, de stad te plaatsen tegenover het (verstedelijkt) platteland. De indeling in urbanisatiegraad is die van het CBS, onder andere gehanteerd bij de volkstelling van 1971 . 
Tabe1 $6.1 \mathrm{~A}$

Reden strafzaak volgens scheldsrechterlijk rapport $(\mathrm{N}=2678)$ (in percentages)

1. aanmerking/opmerking leiding

2. herhaaldelijk maken aan/opmerking leiding

3. bemoeilijken leiding

4. beledigen scheidsrechter

5. onheus bejegenen scheidsrechter

6. handtastelijk optreden t.o.v. de scheidsrechter

7. bedreigen van de scheidsrechter

8. gewelddadig optreden t.o.v. de scheidsrechter

9. onheus bejegenen van tegenspeler

10. beledigen van tegenspeler

11. bedrelgen van tegenspeler

12. vasthouden tegenspeler

13. spuwen naar of van mede- of tegenspeler(s) scheldsrechter of grensrechter(s)

14. Opzettelijk ten val brengen van een tegenspeler

15. ruw en/of onbesulsd en/of gevaarlijk spel

16. herhaaldelijk ruw en/of onbesuisd en/of gevaarlijk spel

17. trappen (raken) van een tegenspeler

18. poging tot trappen (niet raken van een tegenspeler)

19. slaan of stompen (raken) van een tegenspeler

20. poging tot slaan of stompen (niet raken) tegenspeler

21. ander gewelddadig optreden (bijv. elleboog, knie of kopstoot e.d.) t.o.v. tegenspeler

22. handtastelijk optreden t.o.v, tegenspeler

23. met kwalijke bedoeling bal tegen tegenstander goolien of trappen

24. zonder toestemming van scheidsrechter het speelveld verlaten

25. bal wegtrappen bij dood spel om tijd te winnen

26. bal wegtrappen bij dood spel uit protest tegen beslissing scheidsrechter

27. herhaldelifk opzettelijk hands maken

28. gebruiken van onwelvoegiljke taal

29 . wangedrag $t \cdot 0 . v$. een of beide grensrechters

30. wangedrag t.a.v. medespeler(s)

31. wangedrag t:o.v. publiek 
Tabe1 6.3A

T1Jdstip van de strafzaak per kwartier $(\mathrm{N}=2668)$

$\% \quad \mathbb{N}$

le Helft

- le kwartier

$3 \quad 68$

- 2e kwartler

8218

- $3 e$ kwartler

$12 \quad 325$

$2 e$ Helft

- le kwartier

$16 \quad 428$

- 2e kwartier

$30 \quad 803$

- $3 e$ kwartier

totaa1

Tabe1 6.6 .

Korrelatiematrix 4 kenmerken strafzaken

(Pearson $-\mathrm{r})(\mathrm{N}=2664)$

Alle weergegeven coefficlënten signifikant bif $p<0.01$.

1. aard/richting

2. tifdstip

3. scheldsrechterlijke sanktie

$\begin{array}{llll}1 & 2 & 3 & 4\end{array}$

4. tuchtrechtelijke sanktie 
Bijlage 7.1 .

Diskriminantanalyses van 7 wedstrijdtypen onderverdeeld naar aard en richting overtreding (Aliéén de signifikant diskriminerende variabelen zijn vermeld.)

Wedstrijatype 1.

Wedstrijden met instrumentele

overtredingen $t \cdot 0 \cdot v$. speler $(\mathrm{N}=895)$

doelpuntenverschil

wedstrijdzondag

aantal doelpunten

winst/verlies

gestand.diskr · koëff.

kan.korrelatie

.52

.49

.42

.33

.20

Wedstrijdtype 2 .

Wedstrijden met instrumentele overtredingen t.o.v. scheidsrechter $(N=763)$

doelpuntenverschil

kan.korrelatie gestand.diskr.koêff. .77

Wedstrijdtype 3.

Wedstrijden met instrumentele overtredingen t.o.v. speler en scheidsrechter $(N=114)$

doelpuntenverschil gestand.diskr.koeff. aantal doelpunten wedstrijdzondag kan.korrelatie 


\section{Biflage 7.1 . (vervolg)}

Wedstrijdtype 4 .

Wedstrijden met reaktieve over-

tredingen $t \cdot 0 \cdot v$. speler $(N=543)$

urbanisatie

kan.korrelatie

gestand.diskr.koëff.

.75

.13

Wedstrijdtype 5 .

Wedstrijden met reaktleve over-

tredingen $t \cdot 0 \cdot v$ * scheidsrechter $(\mathbb{N}=426)$

af stand

winst/verlies

gestand.diskr.koëff.

kan.korrelatie

.81

.67

.15

Wedstrijdtype 6 .

Wedstrijden met reaktieve overtredingen

t.o.v. speler én scheldsrechter $(N=75)$

geen signiflkante diskriminerende variabelen

kan.korrelatie

gestand.diskr.koëff. .28

Wedstrijdtype 7 .

Wedstrijden met instrumentele en reaktieve overtredingen $(\mathrm{N}=624)$

doelpuntenversch11

gestand.diskr.koëff. verenfigingsgrootte

urbanisatie

.53

kan.korrelatie

.37

.24 
Tabel 8.4 .

Samenhang strafzaken thuis-uitklub en uitslag (uitgaande van thuisklub) (wedstrijden met 1 strafzaak - $N=1088$ ) (percentages vertikaal)

\begin{tabular}{lcccc} 
& & \multicolumn{3}{c}{ uitslag } \\
strafzaken & winst & gelijk & verlies & totaal \\
thuisklub & 35 & 40 & 60 & 45 \\
uitklub & 65 & 60 & 40 & 55 \\
Totaal & -- & -- & -- & --- \\
& $100 \%$ & $100 \%$ & $100 \%$ & $100 \%$
\end{tabular}

tau $C=-.23 p<.001$

Tabe1 8.5 .

Samenhang strafzaken thuis - uitklub en uitslag (wedstrijden met 2 strafzaken; $N=418$ ) (uitgaande van thuisk1ub)

\begin{tabular}{|c|c|c|c|c|}
\hline \multirow[b]{2}{*}{ richting straf } & \multicolumn{4}{|c|}{ uitslag } \\
\hline & winst & gelijk & verlies & totaal \\
\hline $\begin{array}{l}2 \text { straffen } \\
\text { thulsk1ub }\end{array}$ & $10 \%$ & $16 \%$ & $26 \%$ & $17 \%(71)$ \\
\hline $\begin{array}{l}1 \text { straf thuis } \\
\text { en uitklub }\end{array}$ & $53 \%$ & $62 \%$ & $53 \%$ & $55 \%(230)$ \\
\hline uitklub & $37 \%$ & $22 \%$ & $21 \%$ & $28 \%(117)$ \\
\hline Totaa1 & $100 \%$ & $100 \%$ & $100 \%$ & $100 \%$ \\
\hline
\end{tabular}

tau $C-.18 \quad p<.001$ 
Tabe1 8.6.

Samenhang strafzaken thuis - uitklub en uitslag (wedstrijden met 3 strafzaken; $\mathbb{N}=158$ ) (uitgaande van thuisklub)

\begin{tabular}{|c|c|c|c|c|}
\hline \multirow{2}{*}{ richting straf } & \multicolumn{4}{|c|}{ uftslag } \\
\hline & winst & gelijk & ver11es & tota \\
\hline $\begin{array}{l}3 \text { straffen } \\
\text { thuisklub }\end{array}$ & 5 & 5 & 16 & \\
\hline 2 straffen, & & & & \\
\hline 1 straf uit & 25 & 56 & 43 & $36 \%$ \\
\hline 1 straf thuis, & & & & \\
\hline 2 straffen winst & 49 & 30 & 34 & $40 \%$ \\
\hline uitklub & 21 & 9 & 7 & $15 \%$ \\
\hline & 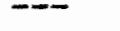 & - & -- & \\
\hline Totaal & $100 \%$ & $100 \%$ & $100 \%$ & $100 \%$ \\
\hline
\end{tabular}

tau $C-.26 p<.001$

Tabel 8.9.

Percentage uit het veldzendingen per aard en richting overtreding voor resp. thuis-en uitklub naar status scheldsrechter $(\mathrm{N}=537)$.

$$
\begin{aligned}
& \text { officielen } \\
& 1 / 2 \text { klasse } 3 / 4 \text { klasse }
\end{aligned}
$$

\begin{tabular}{|c|c|c|c|c|}
\hline Instr./speler & thulsklub & $6 \%$ & 6 & 44 \\
\hline & uitk.1ub & 5 & 7 & 15 \\
\hline instr./scheidsr & thulsklub & 12 & 17 & 60 \\
\hline & ultklub & 16 & 19 & 32 \\
\hline reakt -/speler & thuisk1ub & 30 & 37 & 73 \\
\hline & uitklub & 31 & 44 & 68 \\
\hline reakt./scheidr. & thulsklub & 24 & 19 & 100 \\
\hline & uitklub & 22 & 28 & 68 \\
\hline & & -- & - & -- \\
\hline totaal & thuisklub & 15 & 20 & 67 \\
\hline & u1tk1ub & 15 & 25 & 48 \\
\hline
\end{tabular}


Tabe1 8.11.

Percentage onvoorw. straffen tuchtkommissie per aard en richting overtreding voor resp. thuis- en uitklub naar status scheidsrechter $(\mathrm{N}=1644)$.

$$
\begin{aligned}
& \text { officielen } \\
& 1 / 2 \text { klasse } 3 / 4 \mathrm{klasse}
\end{aligned}
$$

$\begin{array}{ccccc}\text { Instr./speler } \quad \text { thuisklub } & 57 & 57 & 56 \\ & \text { ultklub } & 54 & 45 & 67 \\ \text { instr./scheidsr. thuisklub } & 50 & 58 & 67 \\ & \text { uitklub } & 60 & 55 & 70 \\ \text { reakt./speler thulsklub } & 80 & 85 & 97 \\ & \text { ultklub } & 75 & 85 & 94 \\ \text { reakt./scheldsr.thuisklub } & 54 & 56 & 100 \\ & \text { uitklub } & 47 & 50 & 87\end{array}$


De auteur van dit proefschrift werd op 21 september 1948 te Wassenaar geboren.

Het einddiploma HBS-A werd in 1966 aan het St. Adelbertcollege te Wassenaar behald.

In datzelfde faar werd begonnen aan de studie Westerse Soclologie aan de Rijksuniversiteit te Leiden. In juli 1971 werd het doktoraal eksamen behald met als hoofdvakken empiriese en wijsgerige soctologie en als bijvakken sociologie van de primaire groepsverhoudingen gevolgd aan de Rijksuniversitelt te Utrecht en soclale psychologie.

Daarna volgde één jaar mllitaire dienst, november 1971 tot november 1972; gedurende de diensttijd werd een beroep op de wet gewetensbezwaren gedaan; deze bezwaren werden in maart 1973 officieel erkend.

Van november 1972 tot 1 januari 1974 volgde de eerste periode van werkloosheid; daarna, tot 1 juli 1974 was betrokkene, in het kader van de zgn. TAP-regeling werkzaam bij de Stichting Geestelljke Gezondheidszorg te Heerlen.

Vervolgens volgde een tweede werklozenperiode van $2 \frac{1}{2}$ jaar. Vanaf 1 januari 1977 werd wederom via de TAP-regeling voor een half jaar gewerkt bij de Stichting Sportraad voor de Provincie Limburg te Maastricht.

Van augustus 1977 tot maart 1978 was betrokkene werkzaam bij de Stichting Samenlevingsopbow Oostelijk Mijngebied te Heerlen.

De derde, en voorlopig, latste werklozenperiode duurde van maart 1978 tot augustus 1978. Daarna werd gedurende 2 jaar, tot 1 september 1980, gewerkt bij het Ministerie van Volkshulsvesting en Ruimtelijke Ordening op de afdeling warmteisolatie.

Vanaf 1 september 1980 is betrokkene werkzaam bij de Rijksuniversiteit Limburg, Capaciteitsgroep Medische Sociologie eerst als onderzoeksassistent daarna als wetenschappelijk medewerker (toegevoegd onderzoeker).

Vanaf 1 januari 1982 tot op heden is betrokkene werkzaam ten behoeve van het Instituut Sportgeneeskunde Limburg (ISL). 


\section{Sportwetenschappelijke Onderzoekingen}

1. Dr. M.P. van den Heuvel Sport in de Sovjetunie ISBN 9060760735

2. Dr. B.I. Crum Aan sport georiënteerd onderwijs ISBN 9060760743 uitverkocht

3. Dr. H. Kuipers

Variability of psysiological responses to exercise ISBN $906076188 \mathrm{X}$

4. Dr. H.A. Keizer

Hormonal responses in women as a function of physical exercise and training

ISBN 9060761855

5. Drs. H.H. van der Brug/M. Marseille

Achtergronden van vandalisme bij voetbalwedstrijden

ISBN 9060761944 uitverkocht

6. Dr. B.P.L.M. den Brinker

E.M.G.-feedback bij revalidatie Het toepassen van myofeedback bij stoornissen in het bewegingsapparaat die ertoe geleid hebben dat motorunits te weinig/te veel activiteit of een combinatie van beide vertonen.

ISBN $9060762 \| 18$ - ing. 160 pag.
7. Dr. J.W.I. Tamboer

Mensbeelden achter bewegingsbeelden

Kinantropologische analyses vanuit het perspectief van de lichamelijke opvoeding.

ISBN 9060762126

8. J.M.M. Swinkels/D. J.W. Langenbach (eds.)

Movement analysis by computer for the explosive events in track and field

Report on an international course, organized by the Educational Committee of the Royal Dutch Athletic Federation under auspices of the Dutch Olympic Committee. ISBN 90607622$] 5$

9. Drs. R.C. van Lummel/

M.L.M.P. Haane

Gehandikapten op het CIOS?

Eindadvies van de studie toelating gehandikapten

ISBN 9060762363

11. Dr. H.H. van der Brug Voetbalvandalisme

Een speurtocht naar verklaren factoren

ISBN 9060762509

\section{Verkrijgbaar in de boekhandel}

\section{Uitgeverij De Vrieseborch-Haarlem}

Jacobijnestraat 5, 20ll TG Haarlem

Telefoon 023-9458 